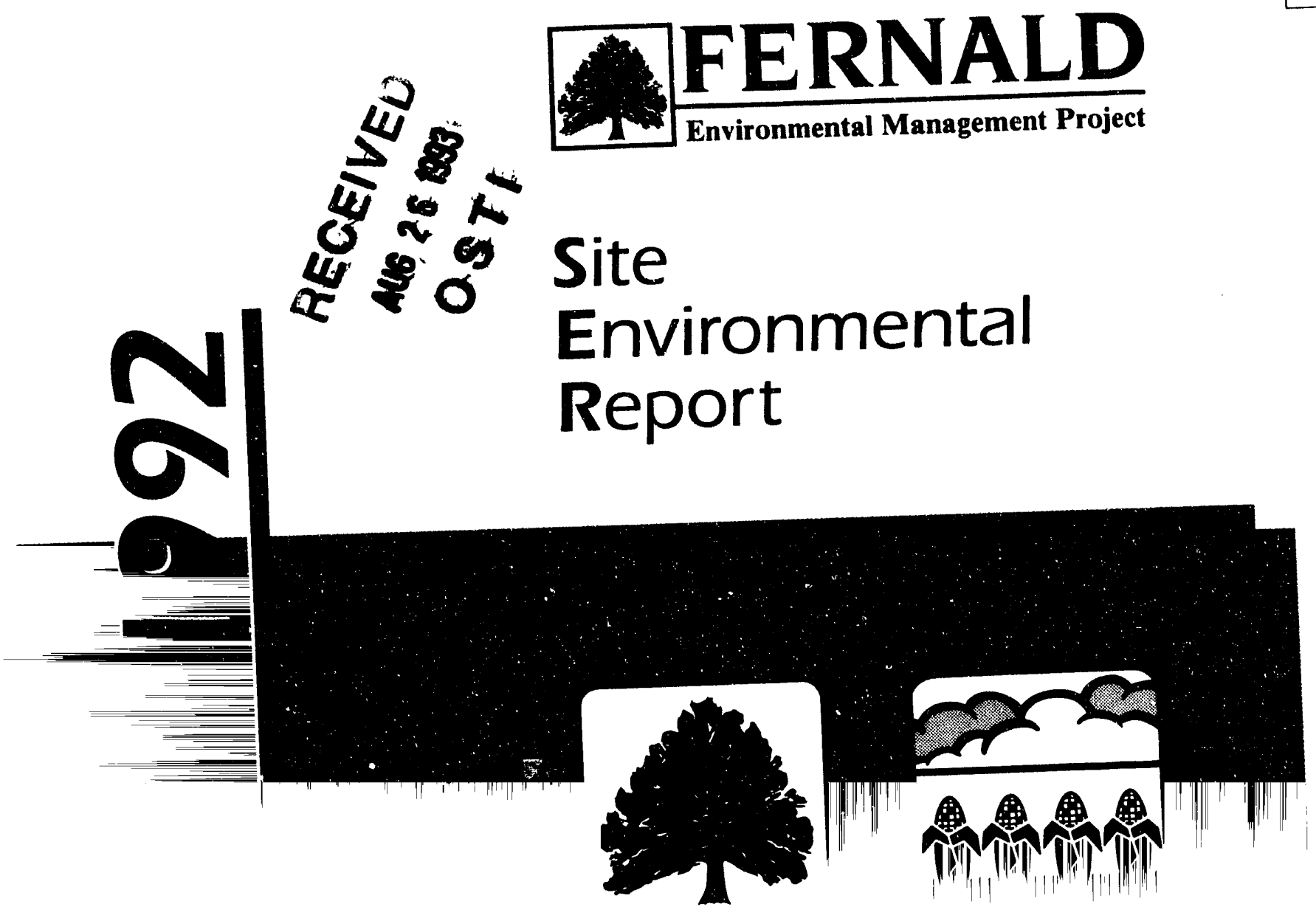




\section{Fernald Site Environmental Report}

Prepared for

U.S. Department of Energy

Fernald Field Office

Contract DE - AC05 - 92OR21972

Prepared by

Fernald Environmental Restoration Management Corporation

Environmental Protection Department

Environmental Monitoring and Surveillance Section

Radiological Environmental Monitoring Group

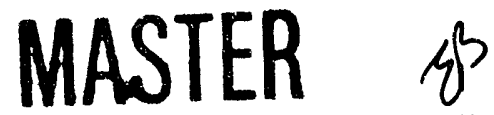

June 1993 
Notice This report was prepared as an account of work sponsored by an agency of the United States government. Neither the United States government or any agency thereof, nor any of their employees, nor any of is contractors, subcontractors nor their employees, make any warranty, expressed or im, lied, or assume any legal liability or responsibility for the accuracy, completeness, or usefulness of any information, apparatus, product, or process disclosed, or represent that its use would not infringe privately owned rights. Reference herein to any specifi- commercial product, process, or service by trade name, manufacturer or otherwise, does not necessarily constitute or imply its endorsement, recommendation, or favoring by the United States government or any agency thereof. The views and opinions of authors expressed herein do not necessarily state or reflect those of the United States government or any agency thereof, or Fernald Environmental Restoration Management Corporation, its affiliates or its parent companies.

This report has been reproduced from the best available copy.

Available to DOE and DOE contractors from:

The Office of Scientific and Technical Information

P.O. Box 62

Oak Ridge, TN 37831

Prices available from (615) 576-8401, FTS 626-8401.

Available to the public from:

The National Technical Information Service

U.S. Department of Commerce

5285 Port Royal Road

Springfield, VA 22161

Printed Copy Price: $A 12$

Microfiche Price: $\mathrm{AO} 1$ 


\section{Table of Contents}

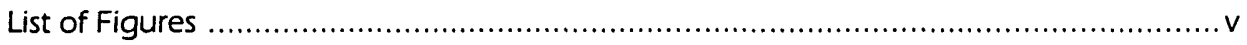

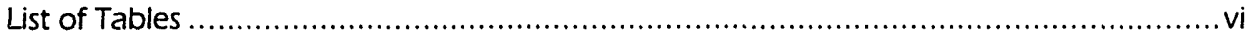

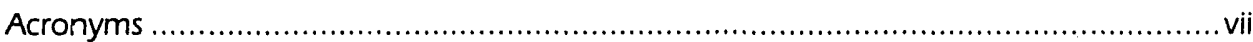

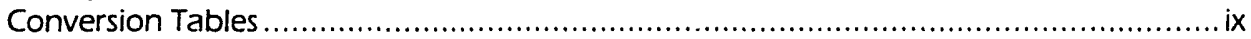

Executive Summary $\quad$ xi

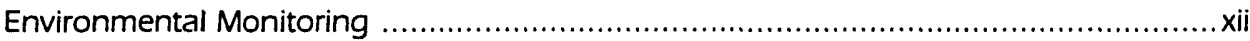

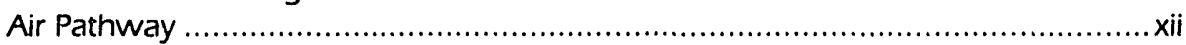

Radon Monitoring ..................................................................... xiii

Liquid Pathway: Effluent and Surface Water ..........................................

Liquid Pathway: Groundwater ................................................................

Estimated Radiation Doses for 1992 .............................................................. xiv

Dose Attributable to Radon ............................................................

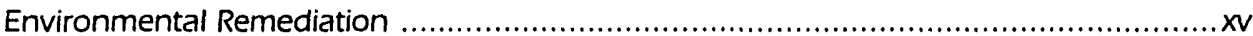

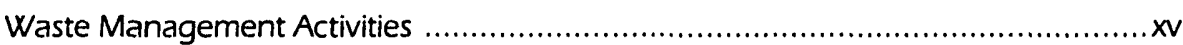

Remedial Investigation and Feasibility Study ........................................

Chapter 1 - Introduction to the Site 1

The Fernald Site Mission: Environmental Compliance and Restoration......................... 2

An Overview of Former Production Operations .......................................... 4

Handling and Storing Radioactive and Hazardous Materials ............................. 8

Purpose of the Environmental Monitoring Program ................................... 8

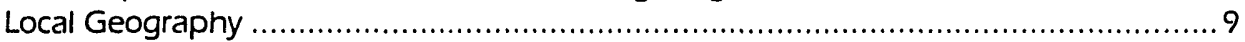

Geologic History ......................................................................... 9

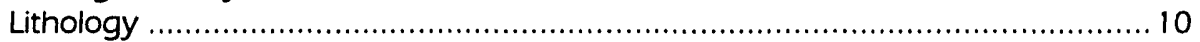

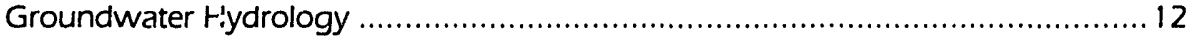

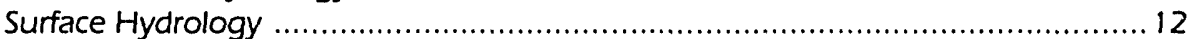

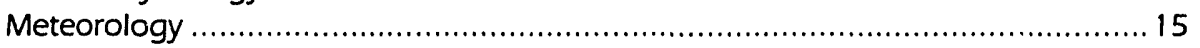

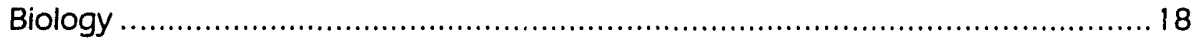

Demography and Land Use .............................................................. 18

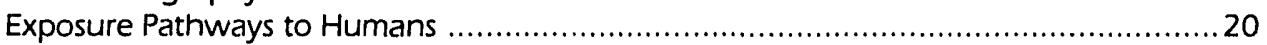

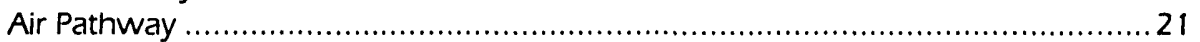

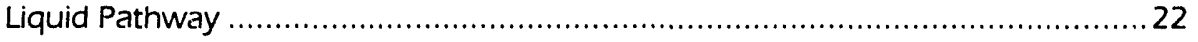

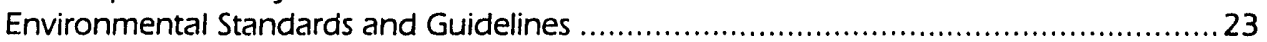

Chapter $\mathbf{2}$ - Fundamentals of Radiation and Health Hazards 25

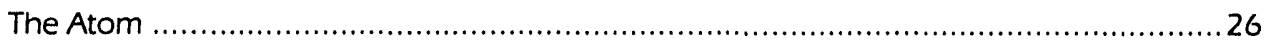

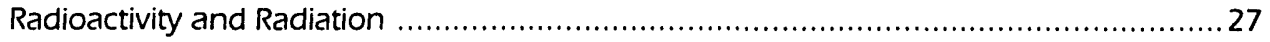

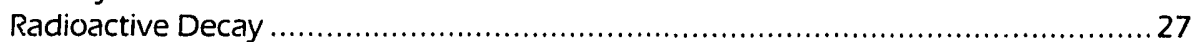

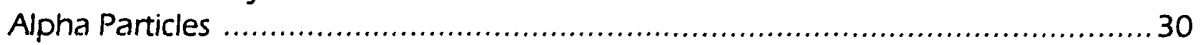

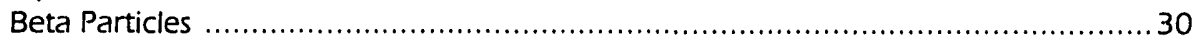

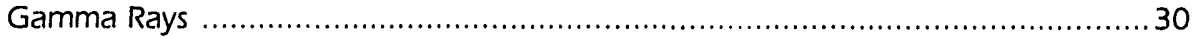

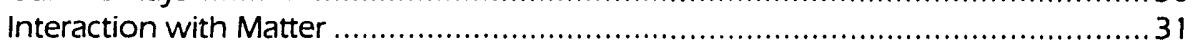

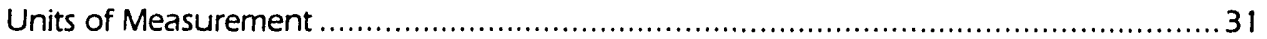

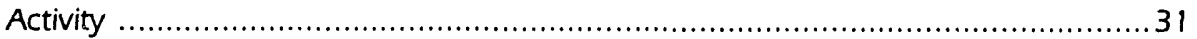

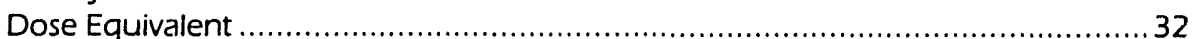

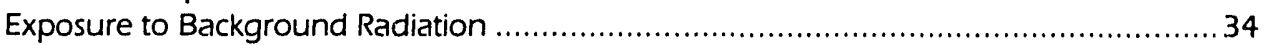

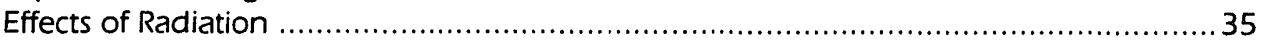

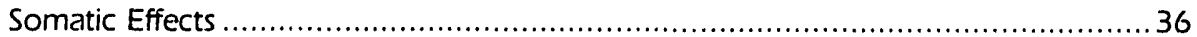

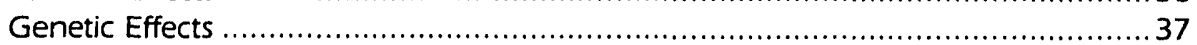

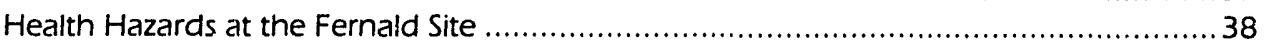

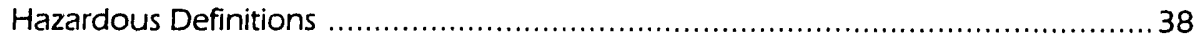

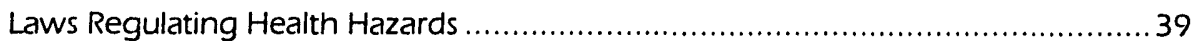

Types of Health Threats ............................................................. 40 


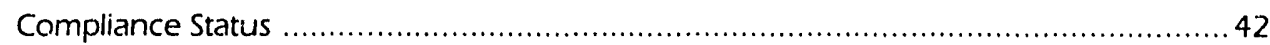

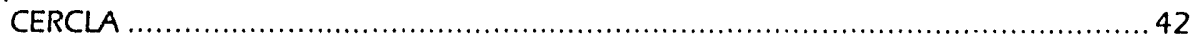

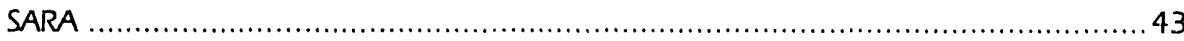

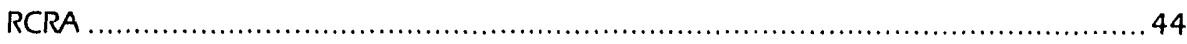

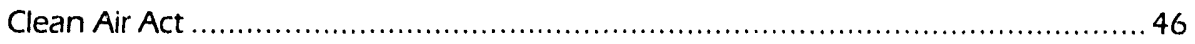

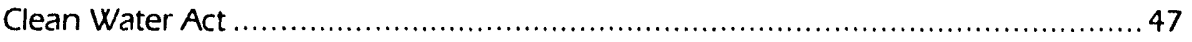

NPDES Effluent Regulation ......................................................... 47

NPDES Stormwater Regulation ................................................... 49

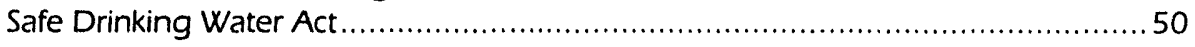

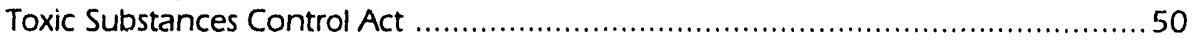

Ohio Solid Waste Act .................................................................... 51

Federal Insecticide, Fungicide, and Rodenticide Act ................................ 51

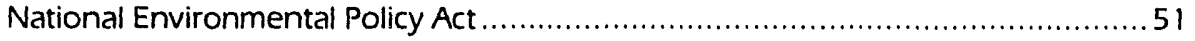

Endangered Species Act .................................................................. 52

Executive Order 11990, "Protection of Wetlands" ....................................... 53

Executive Order 11988, "Floodplain Management" ......................................5 53

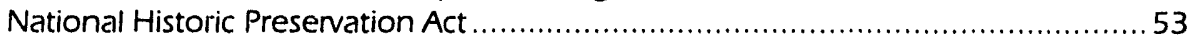

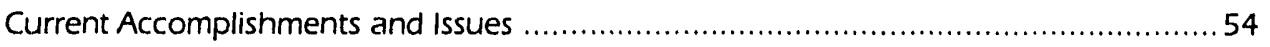

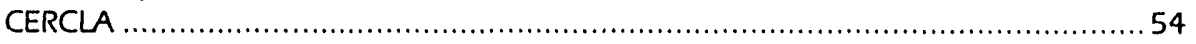

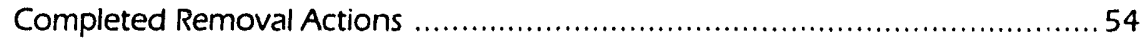

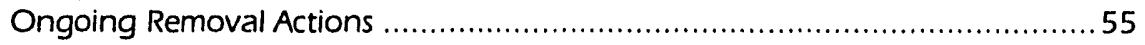

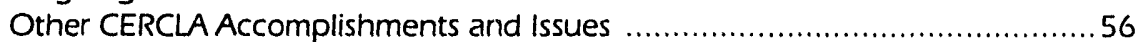

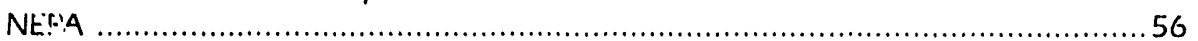

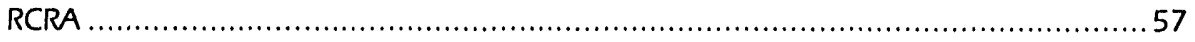

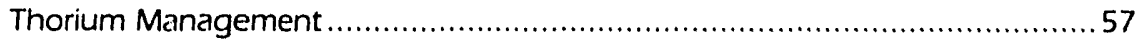

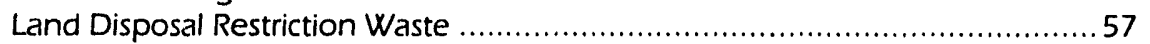

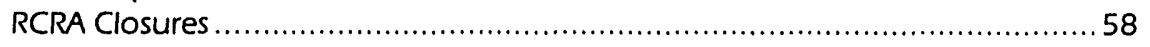

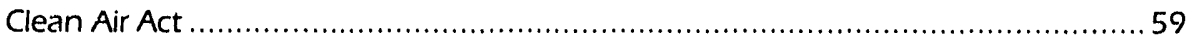

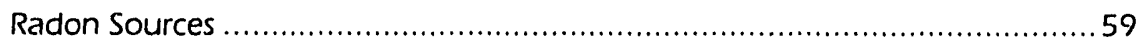

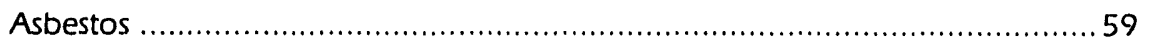

Toxic Substances Control Act ......................................................60 60

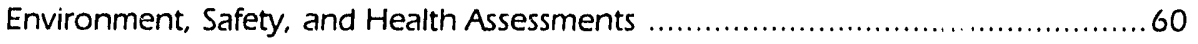

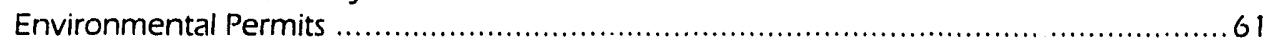

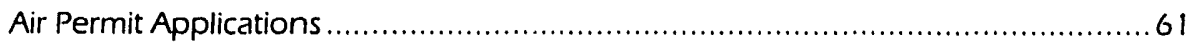

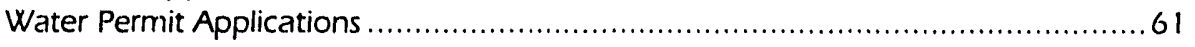

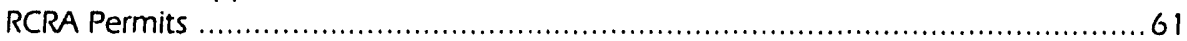

Chapter 4 - Air Pathway Monitoring $\quad 63$

Monitoring for Radioactive Pollutants .....................................................65 65

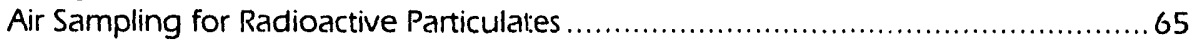

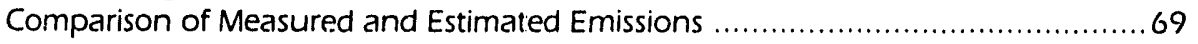

Soil Sampling for Uranium ................................................................. 71

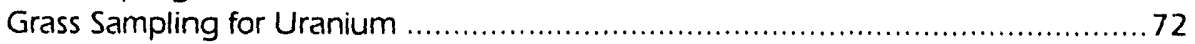

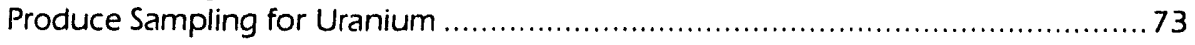

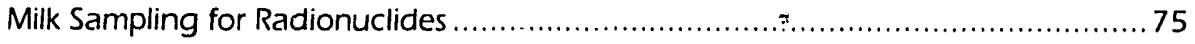

Monitoring for Direct Radiation .............................................................. 77

Monitoring for Nonradioactive Pollutants ............................................... 77

Chapter 5 - Liquid Pathway: Effluent and Surface Water Monitoring 79

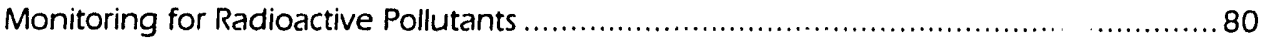

Effluent Sampling for Radionuclides .................................................. 80

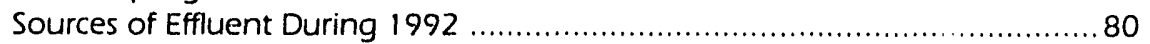

Sampling Methodologies ......................................................... 82

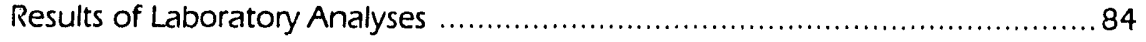

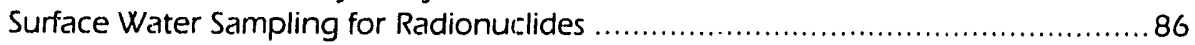

Sampling Methodologies .......................................................... 86

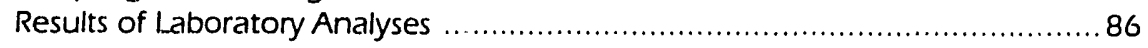

Sediment Sampling for Radionuclides .................................................. 89

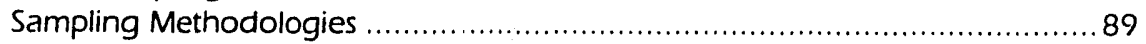

Results of Laboratory Analyses .................................................. 91 
Fish Sampling for Uranium ............................................................. 91

Sampling Methodologies ............................................................. 91

Results of Laboratory Analysis ...................................................... 93

Monitoring for Nonradioactive Pollutants ................................................. 94

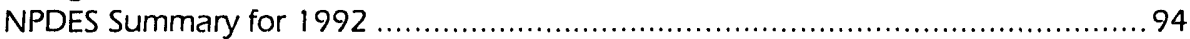

Surface Water Sampling for Water-Quality Indicators ................................ 94

Chapter 6 - Liquid Pathway: Groundwater Monitoring 95

History of Groundwater Monitoring at the Site ....................................... 96

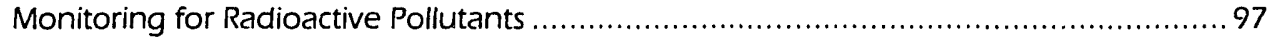

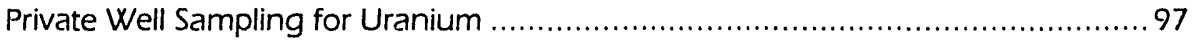

Comprehensive Sampling for Uranium ............................................... 100

Comprehensive Groundwater Monitoring for Other Radionuclides .................. 103

South Groundwater Contamination Plume ............................................ 103

Monitoring for Nonradioactive Pollutants .................................................... 105

Private Well Sampling for Metals ..................................................... 105

Comprehensive Sampling for Hazardous Substances ................................ 105

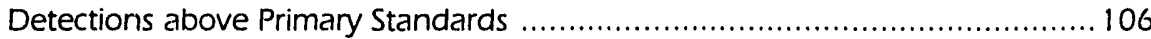

Detections above Secondary Standards ..........................................111

The RCRA Groundwater Assessment Program .................................111

Chapter 7 - Estimated Radiation Doses for 1992

Methodology for Calculating Total Radiation Dose .................................... 114

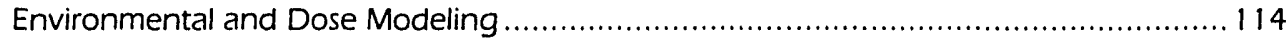

Air Pathway Dose Calculations ........................................................ 115

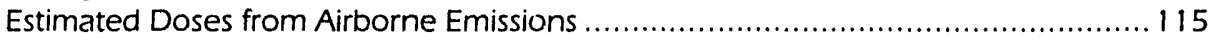

Estimated Dose from Eating Foodstuffs Produced near the Fernald Site ............. 117

Direct Radiation Dose .................................................................. 118

Liquid Pathway Dose Calculations ..................................................... 119

Estimated Background Dose from Drinking Well Water

Estimated Dose from Drinking Great Miami River Water .................................119

Estimated Dose from Eating Fish from the Great Miami River ........................... 120

Total of Doses to a Maximally Exposed Individual ...................................... 120

Significance of Estimated Radiation Doses for 1992 ........................................ 121

$\begin{array}{ll}\text { Chapter } 8 \text { - The Radon Monitoring Program } & 123\end{array}$

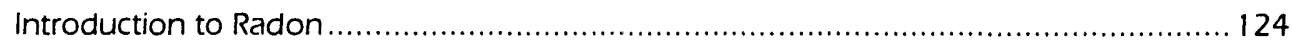

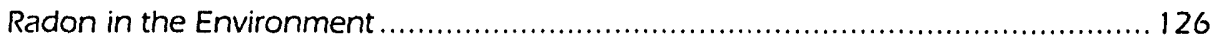

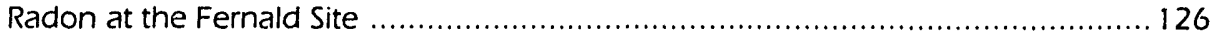

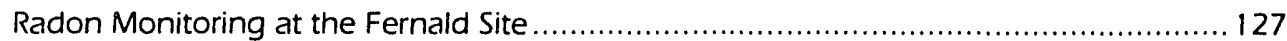

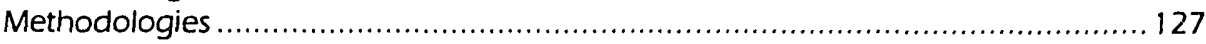

1992 Radon Monitoring Results ................................................... 128

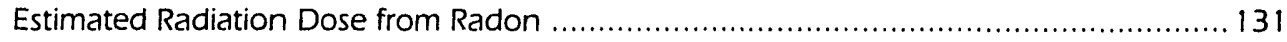

Control of Radon at the Fernald Site .................................................... 133

Chapter 9 - Quality Assurance for the Environmental Monitoring Program 135

Sitewide CERCLA Quality Assurance Project Plan ....................................... 136

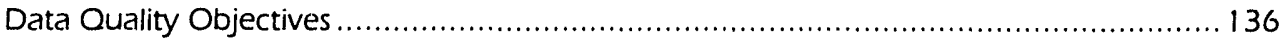

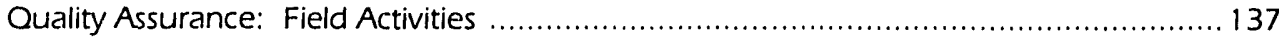

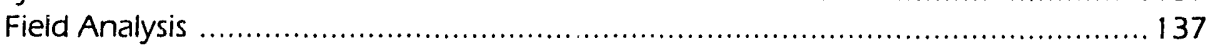

Field OARepresentative Sampling .............................................. 137

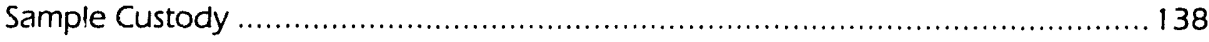

Field Documentation ................................................................. 138

Analytical Laboratory Quality Assurance .................................................. 139

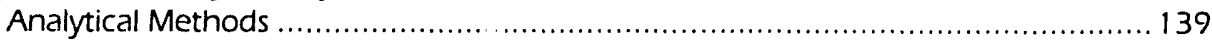

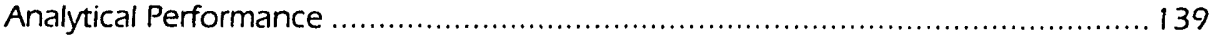

Detection of Data Problems and Corrective Action .................................. 140 
Independent Evaluations of the Fernald Site Laboratories

DOE's Environmental Measurements Laboratory ...................................... 140

USEPA's Discharge Monitoring Report .................................................. 141

Commercial Proficiency Environmental Testing ............................................ 141

Ohio Department of Health Split Samples .............................................. 142

Contract Laboratory Quality Assurance ................................................ 143

$\begin{array}{lr}\text { Chapter } 10 \text { - Waste Management Activities } & 145\end{array}$

Categories of Waste at the Fernald Site .................................................. 147

Low-Level Radioactive Waste Management ............................................. 149

Storing Low-Level Radioactive Wastes ............................................. 149

Disposing of Low-Level Radioactive Wastes ....................................... 150

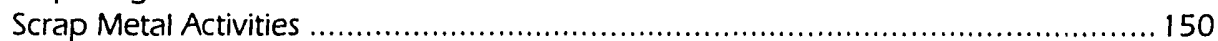

Managing Thorium at the Fernald Site ............................................ 151

Hazardous and Mixed Waste Management ............................................ 152

Performing RCRA Closures ........................................................... 153

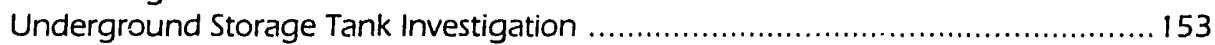

Conventional Industrial Waste Management ................................................. 154

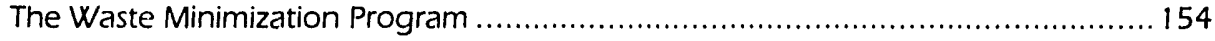

$\begin{array}{ll}\text { Chapter } 11 \text { - Remedial Investigation and Feasibility Study } & 157\end{array}$

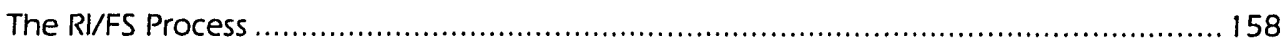

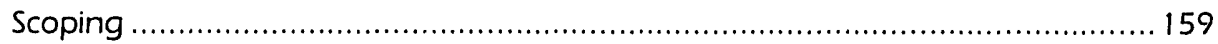

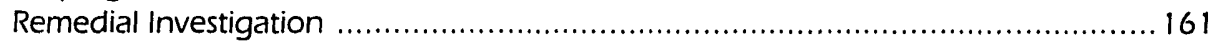

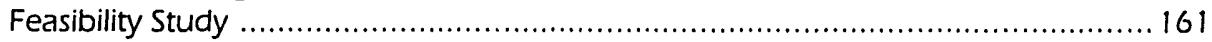

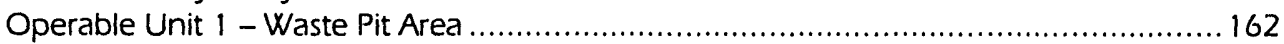

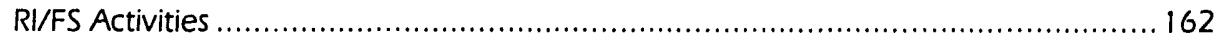

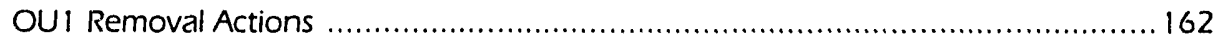

Operable Unit 2 - Other Waste Units .................................................. 164

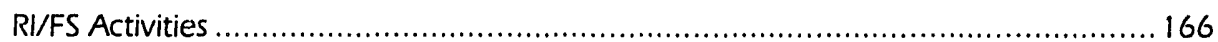

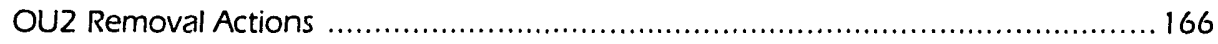

Operable Unit 3 - Former Production Area ............................................ 167

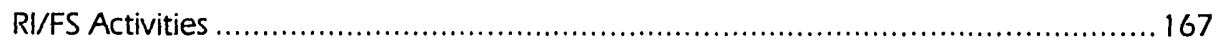

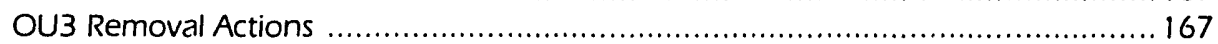

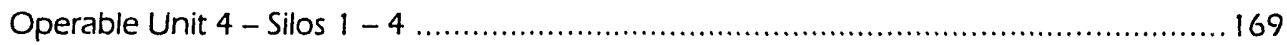

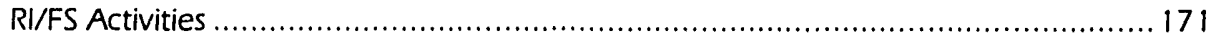

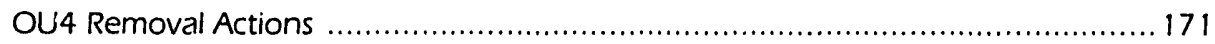

Operable Unit 5 - Environmental Media ...................................................... 171

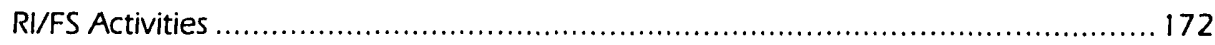

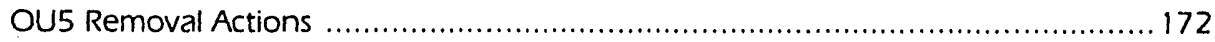

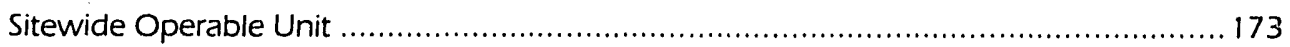

\section{Appendices}

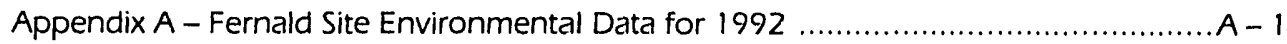

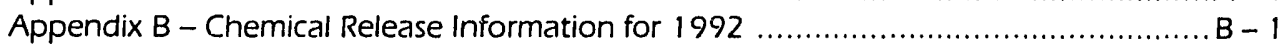

Appendix C - References ..................................................................

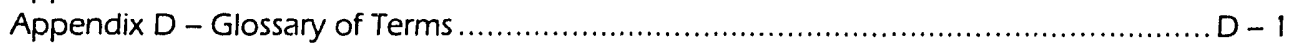




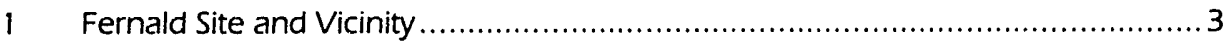

2 Former Site Production Process .................................................. 5

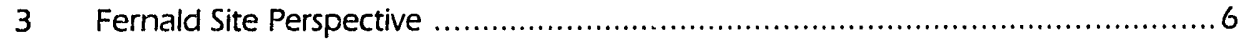

4 Cross-Section of the New Haven Trough, Looking North ............................... 11

5 Buried Valley Aquifer Underlying the Fernald Site and Vicinity .................... 13

6 Great Miami River Drainage Basin ............................................. 14

$7 \quad 1992$ Wind Rose Data, 10-Meter Height .............................................. 16

81992 Wind Rose Data, 60-Meter Height ............................................. 17

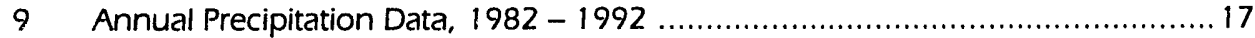

10 Major Communities in Southwestern Ohio ............................................... 19

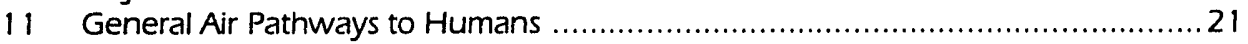

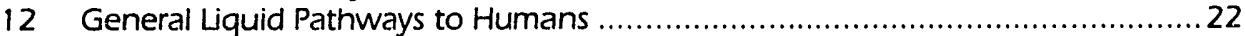

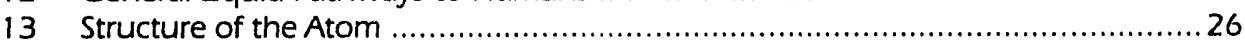

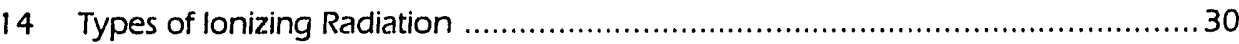

15 Comparison of Disintegration Rate ................................................... 31

16 Organs Affected by Substances Found at the Fernald Site .......................... 33

17 Expcsure to Background Radiation ................................................ 34

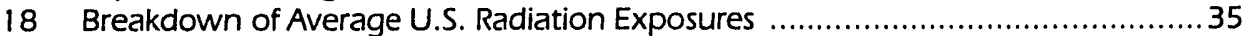

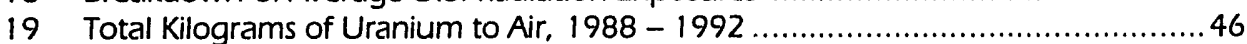

20 NPDES Effluent and Stormwater Monitoring Locations ............................. 48

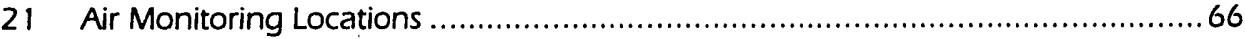

22 Average Uranium Concentrations in Air, 1988 - 1992 ...............................68

23 Average Thorium-232 Concentrations in Air, $1988-1992 \ldots \ldots \ldots \ldots \ldots \ldots \ldots \ldots . . \ldots 9$

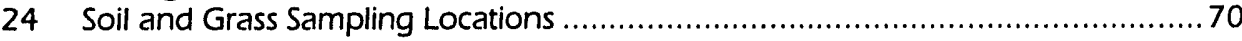

25 Range of Total Uranium Occurring in Surface Soils .................................. 71

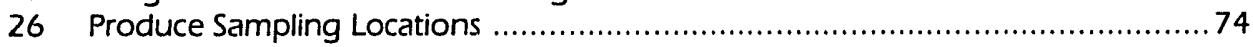

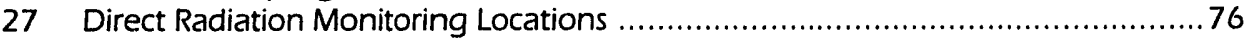

28 Fernald Site Effluent Flow Diagram .............................................. 81

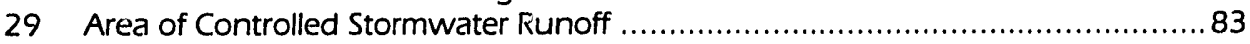

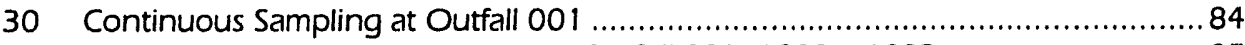

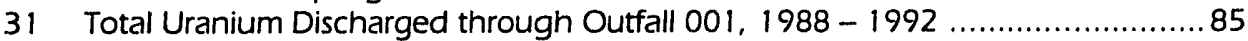

32 Surface Water Sampling Locations .................................................. 87

33 Average Uranium Concentrations in Surface Water, $1988-1992 \ldots \ldots \ldots \ldots \ldots \ldots \ldots . .68$

34 Sediment Sampling Locations ....................................................... 90

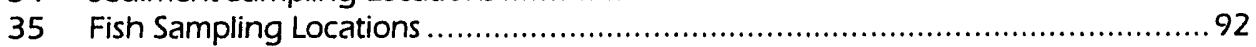

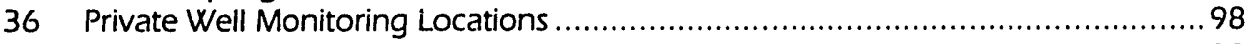

37 Average Uranium Concentrations in Private Wells, $1988-1992$....................99

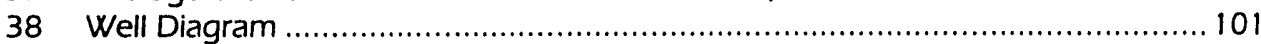

39 Monitoring Well Depths and Screen Locations .................................. 102

40 South Groundwater Contamination Plume ............................................. 104

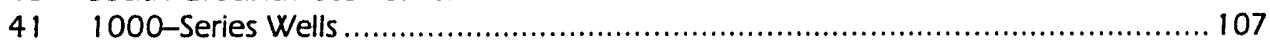

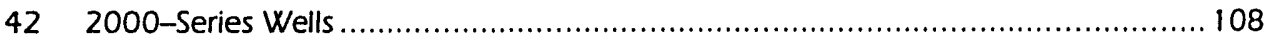

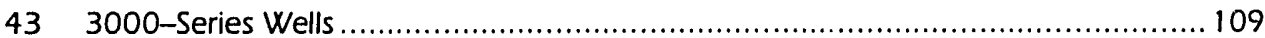

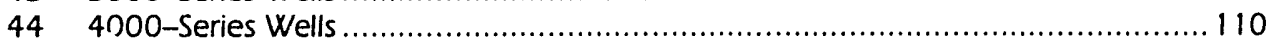

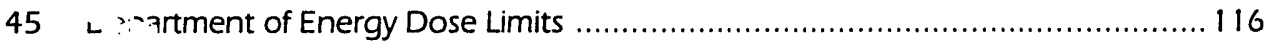

46 Great Miami River Dose ............................................................. 119

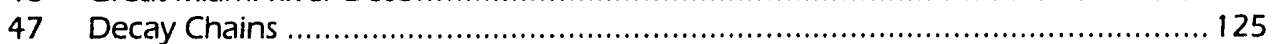

48 Offsite and Fenceline Radon Monitoring Locations ................................ 129

49 Real-Time Radon Monitoring Locations .............................................. 130

50 Radon Monitoring Locations Near the Silos ........................................... 132

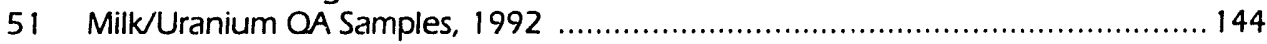

52 Drum Equivalents ................................................................... 145

53 Fernald Site Waste Management Areas ................................................ 148

54 Overpacking of Drums ............................................................. 149

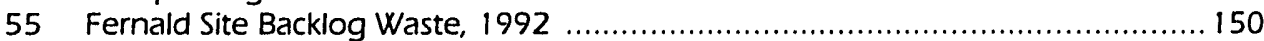

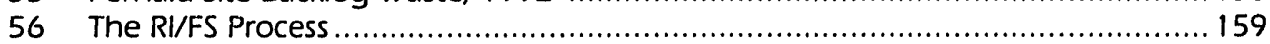

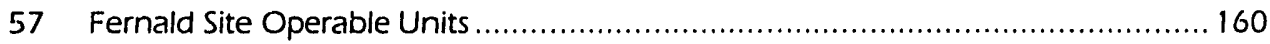

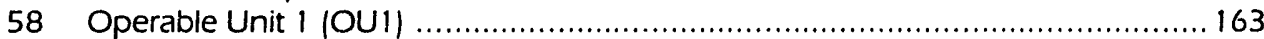

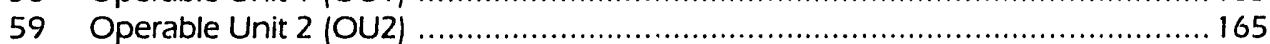

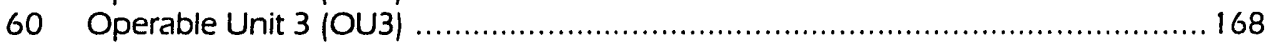

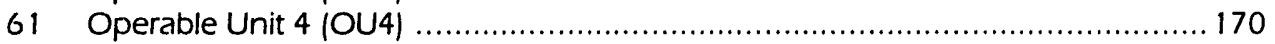




\section{List of Tables}

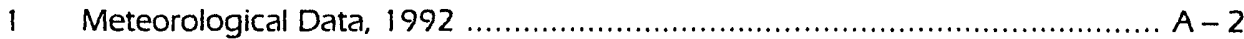

2 Estimated Population Distribution within $80 \mathrm{~km}$ (50 miles)

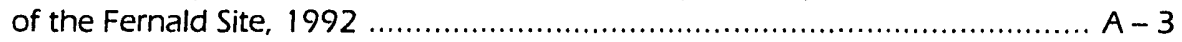

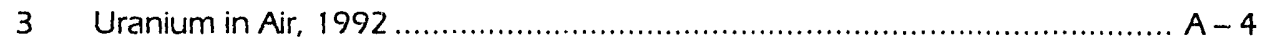

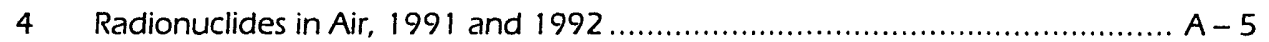

5 Comparison of Measured and Estimated Airborne Uranium Concentrations at the Fernald Site Fenceline .......................................................... $A-11$

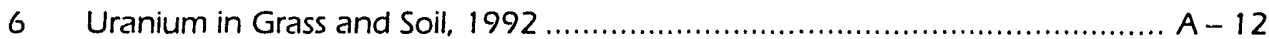

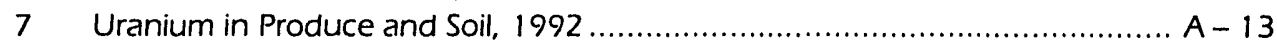

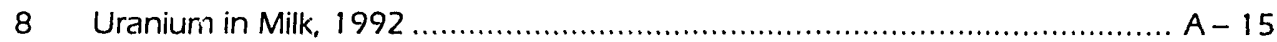

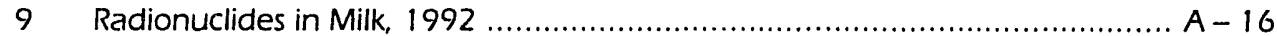

10 Environmental TLD Direct Radiation Measurements, 1992 ........................ A - 17

11 Radionuclides Discharged to the Great Miami River, 1992 ....................... A - 18

12 Radionuclides in Surface Water, 1992 ............................................ A - 19

13 Radioisotopes in Great Miami River, Paddys Run

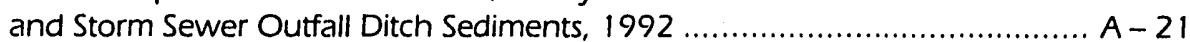

14 Uranium Concentrations in Fish from the Great Miami River, 1992 ............. A - 22

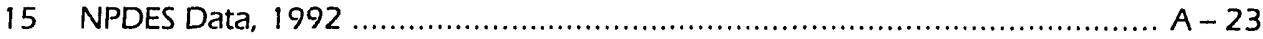

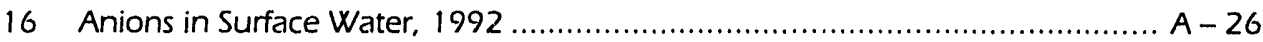

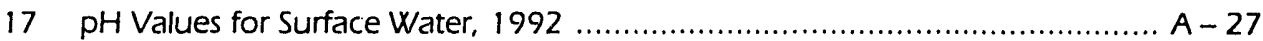

18 Uranium in Private Wells, 1992 .................................................... A - 28

19 Comprehensive Groundwater Samples with Uranium Concentrations above USEPA Proposed Standard, 1992 ........................................... A 29

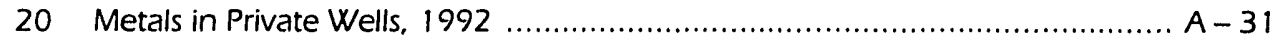

21 Nonradioactive Substances

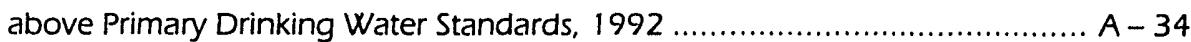

22 Summary of Radiation Dose ........................................................ 36

23 Estimated Airborne Emissions for the Fernald Site, 1992 .......................... A - 37

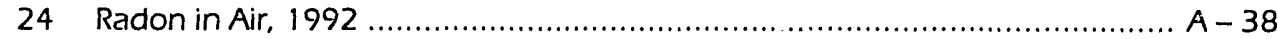

25 DOE Quality Assessment Program for Environmental Radionuclide Analyses Fernald Site Laboratories Performance Results, 1992 ... A-39

26 USEPA Quality Assurance Program for Wastewater Analyses

Fernald Site Laboratories Performance Evaluation, $1992 \ldots \ldots \ldots \ldots \ldots \ldots \ldots \ldots . . . . . . . . . . . . . .40$

27 Proficiency Environmental Testing Quality Assurance Program

for Water Analyses, 1992 .............................................................. A -41

28 Fernald Site - ODH Uranium Sampling Comparison, $1991 \ldots \ldots \ldots \ldots \ldots \ldots \ldots \ldots . . . \ldots$ - 43 


\title{
Acronyms
}

\author{
AEC Atomic Energy Commission \\ AHF Anhydrous Hydrogen Fluoride \\ ALARA As Low As Reasonably Achievable \\ AMS Air Monitoring Station \\ ANSI American National Standards Institute \\ ARAR Applicable or Relevant and Appropriate Requirement \\ ASER Annual Site Environmental Report \\ AWWT Advanced Wastewater Treatment \\ BAT Best Available Technology \\ BDN Biodenitrification Facility \\ BMP Best Management Practices \\ BOD,5 Five-Day Biochemical Oxygen Demand \\ BOD,C Carbonaceous Oxygen Demand \\ BSL Biodenitrification Surge Lagoon \\ CERCLA Comprehensive Environmental Response, Compensation, and Liability Act \\ CFR Code of Federal Regulations \\ CPID Closure Plan Information and Data \\ CX Categorical Exclusion \\ DCG Derived Concentration Guideline \\ DE Drum Equivalent \\ DOE Department of Energy \\ DQO Data Quality Objective \\ EA Environmental Assessment \\ EDE Effective Dose Equivalent \\ EDL Economic Discard Limit \\ EE/CA Engineering Evaluation/Cost Analysis \\ EIS Environmental Impact Statement \\ EM Environmental Monitoring \\ EML Environmental Measurements Laboratory \\ ES\&H Environment, Safety, and Health \\ ETS Effluent Treatment System \\ FEMP \\ FERMCO \\ Fernald Environmental Management Project \\ FFA Federal Facility Agreement \\ FFCA Federal Facility Compliance Agreement \\ FFCAct Federal Facility Compliance Act \\ FIFRA Federal Insecticide, Fungicide, and Rodenticide Act \\ FMPC Feed Materials Production Center \\ FONSI Finding of No Significant Impact \\ FS Feasibility Study \\ HSL Hazardous Substances List \\ HWMU Hazardous Waste Management Unit \\ IAWWT Interim Advanced Wastewater Treatment \\ ICRP International Commission on Radiological Protection \\ LDR Land Disposal Restriction \\ LLW Low-Level Radioactive Waste \\ MGD Million Gallons per Day \\ NAAOS National Ambient Air Quality Standards \\ NCRP National Council on Radiation Protection and Measurements \\ NEPA National Environmental Policy Act \\ NESHAP National Emission Standards for Hazardous iur Pollutants \\ NOD Notice of Deficiency \\ NON Notice of Noncompliance
}




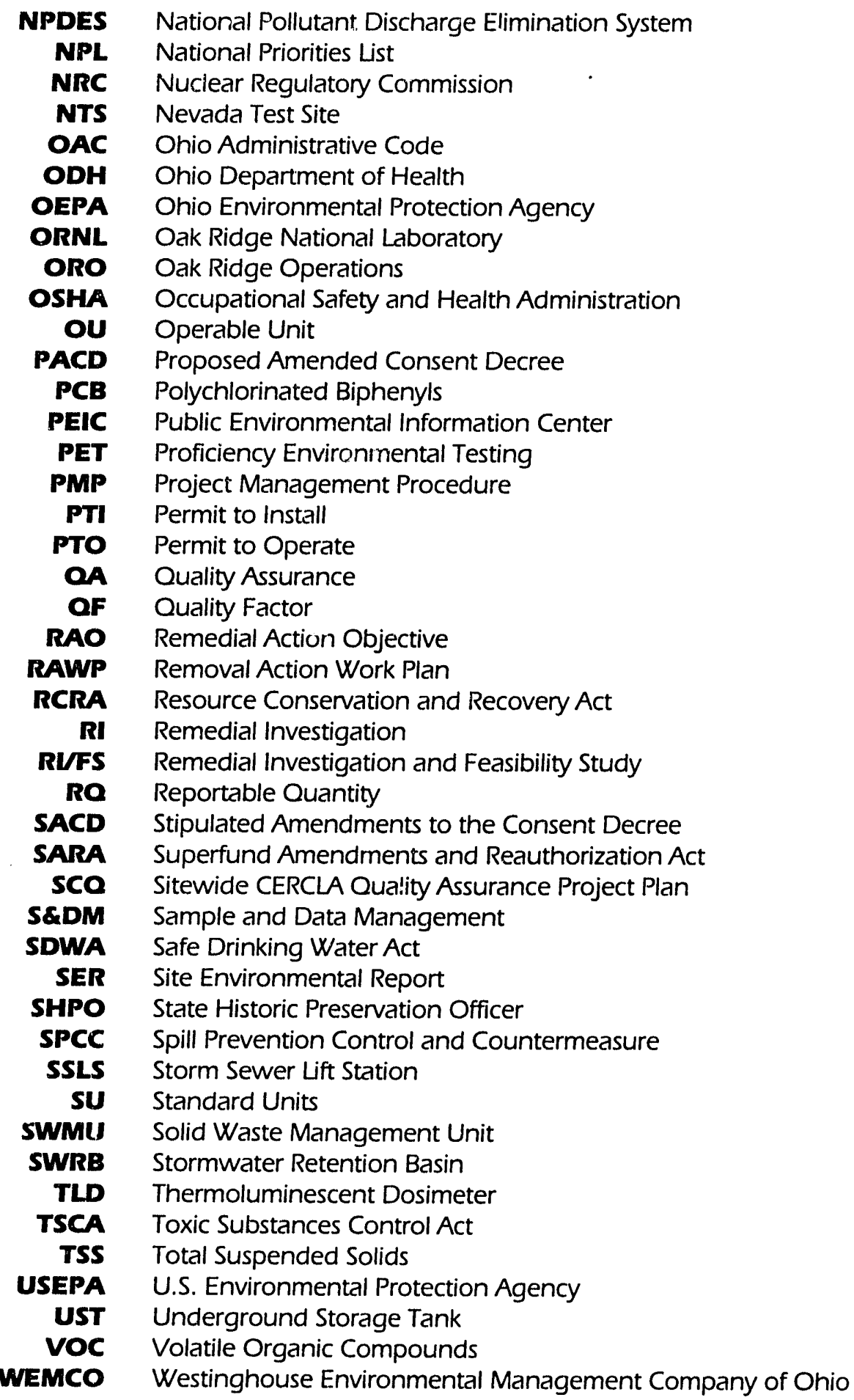




\section{Conversion Tables}

In this report, the metric system is used to measure length, volume, and mass, while the English system units are often presented in parentheses for the reader's reference. To measure radioactivity, exposure, and dose, the traditional radiological units (Curie, Roentgen, rad, and rem) are used; for conversion to the Systeme International units (Becquerel and Sievert), use the conversion factors in this table.

\begin{tabular}{|lrll|}
\hline Multiple & Decimal Equivalent & Prefix & Symbol \\
\hline $10^{6}$ & $1,000,000$ & mega- & $\mathrm{M}$ \\
$10^{3}$ & 1,000 & kilo- & $\mathrm{K}$ \\
$10^{2}$ & 100 & hecto- & $\mathrm{h}$ \\
10 & 10 & deka- & $\mathrm{da}$ \\
$10^{-1}$ & 0.1 & deci- & $\mathrm{d}$ \\
$10^{-2}$ & 0.01 & centi- & $\mathrm{C}$ \\
$10^{-3}$ & 0.001 & milli- & $\mathrm{m}$ \\
$10^{-6}$ & 0.000001 & micro- & $\mu$ \\
$10^{-9}$ & 0.000000001 & nano- & $\mathrm{n}$ \\
$10^{-12}$ & 0.000000000001 & pico- & $\mathrm{p}$ \\
$10^{-15}$ & 0.000000000000001 & femto- & $\mathrm{f}$ \\
$10^{-18}$ & 0.000000000000000001 & atto- & $\mathrm{a}$ \\
& & & \\
\hline
\end{tabular}

\begin{tabular}{|c|c|c|c|c|c|}
\hline Multiply & By & To Obtain & Multiply & By & To Obtain \\
\hline \multicolumn{6}{|l|}{ Length } \\
\hline inches & 2.54 & centimeters $(\mathrm{cm})$ & $\mathrm{cm}$ & 0.394 & inches \\
\hline yards & 0.92 & meters $(\mathrm{m})$ & $\mathrm{m}$ & 1.09 & yards \\
\hline miles & 1.61 & kilometers $(\mathrm{km})$ & $\mathrm{km}$ & 0.62 & miles \\
\hline \multicolumn{6}{|l|}{ Volume } \\
\hline cubic centimeters $\left(\mathrm{cm}^{3}\right)$ & 1 & milliliters ( $\mathrm{mL})$ & $\mathrm{mL}$ & 1 & $\mathrm{~cm}^{3}$ \\
\hline cubic inches $\left(\mathrm{in}^{3}\right)$ & 16.39 & $\mathrm{~mL}$ & $\mathrm{~mL}$ & 0.061 & $\mathrm{in}^{3}$ \\
\hline fluid ounces & 29.59 & $\mathrm{~mL}$ & $\mathrm{~mL}$ & 0.034 & fluid ounce \\
\hline $\operatorname{gram}(9)$ & 1 & $\mathrm{~mL}$ (water) & $\mathrm{mL}$ (water) & 1 & $g$ \\
\hline kilogram (kg) & 1 & liter (ㄴ) (water) & L (water) & 1 & $\mathrm{~kg}$ \\
\hline $\mathrm{mL}$ & 1,000 & $\mathrm{~L}$ & $L$ & 0.001 & $\mathrm{~mL}$ \\
\hline gallons & 3.79 & $\mathrm{~L}$ & L & 0.264 & gallons \\
\hline quarts & 0.95 & $\mathrm{~L}$ & $L$ & 1.057 & quarts \\
\hline cubic feet $\left(\mathrm{ft}^{3}\right)$ & 0.02833 & cubic meters $\left(\mathrm{m}^{3}\right)$ & $m^{3}$ & 35.3 & $\mathrm{ft}^{3}$ \\
\hline gallons & 0.018 & drum equivalents (DE) & $\mathrm{DE}$ & 55 & gallons \\
\hline $\mathrm{m}^{3}$ & 4.76 & $\mathrm{DE}$ & $\mathrm{DE}$ & 0.21 & $\mathrm{~m}^{3}$ \\
\hline $\mathrm{ft}^{3}$ & 0.135 & $\mathrm{DE}$ & $\mathrm{DE}$ & 7.4 & $\mathrm{ft}^{3}$ \\
\hline \multicolumn{6}{|l|}{ Mass } \\
\hline ounces & 28.33 & $g$ & $g$ & 0.035 & ounces \\
\hline pounds & 455 & $g$ & $g$ & 0.0022 & pounds \\
\hline pounds & 0.455 & $\mathrm{~kg}$ & $\mathrm{~kg}$ & 2.2 & pounds \\
\hline tons & 0.907 & metric tons & metric tons & 1.1 & tons \\
\hline
\end{tabular}




\begin{tabular}{|c|c|c|c|c|c|}
\hline Multiply & By & To Obtain & Multiply & By & To Obtain \\
\hline \multicolumn{6}{|l|}{ Activity } \\
\hline $\begin{array}{l}\text { Curies (Ci) } \\
\text { disintegrations } \\
\quad \text { per minute (dpm) } \\
\text { Becquerel (Bq) } \\
\mathrm{Ci} \\
\text { disintegrations } \\
\text { per second (dps) } \\
\text { dpm } \\
\text { dps } \\
\text { dpm } \\
\text { dps } \\
\text { pCi }\end{array}$ & $\begin{array}{l}10^{12} \\
0.45 \\
27.02 \\
10^{6} \\
\\
2.7 \times 10^{-5} \\
4.5 \times 10^{-7} \\
2.7 \times 10^{-11} \\
4.5 \times 10^{-13} \\
1 \\
0.037\end{array}$ & $\begin{array}{l}\text { picocuries (pCi) } \\
\mathrm{pCi} \\
\mathrm{pCi} \\
\text { microcurie ( } \mu \mathrm{Ci}) \\
\mu \mathrm{Ci} \\
\mu \mathrm{Ci} \\
\mathrm{Ci} \\
\mathrm{Ci} \\
\mathrm{Bq} \\
\mathrm{Bq}\end{array}$ & $\begin{array}{l}\mathrm{pCi} \\
\mathrm{pCi} \\
\mathrm{pCi} \\
\mu \mathrm{Ci} \\
\\
\mu \mathrm{Ci} \\
\mu \mathrm{Ci} \\
\mathrm{Ci} \\
\mathrm{Ci} \\
\mathrm{Bq} \\
\mathrm{Bq}\end{array}$ & $\begin{array}{l}10^{-12} \\
2.22 \\
0.037 \\
10^{-6} \\
\\
3.7 \times 10^{4} \\
2.22 \times 10^{6} \\
3.7 \times 10^{10} \\
2.22 \times 10^{12} \\
1 \\
27\end{array}$ & $\begin{array}{l}\mathrm{Ci} \\
\mathrm{dpm} \\
\mathrm{Bq} \\
\mathrm{Ci} \\
\mathrm{dps} \\
\mathrm{dpm} \\
d p s \\
\mathrm{dpm} \\
\mathrm{dps} \\
\mathrm{pCi}\end{array}$ \\
\hline \multicolumn{6}{|l|}{ Dose } \\
\hline $\begin{array}{l}\text { rem } \\
\text { Sievert (SW) } \\
\text { For Natural Uraniur }\end{array}$ & $\begin{array}{l}1,000 \\
100 \\
\text { Water }\end{array}$ & $\begin{array}{l}\text { millirem (mrem) } \\
\text { rem }\end{array}$ & $\begin{array}{l}\text { mrem } \\
\text { rem }\end{array}$ & $\begin{array}{l}0.001 \\
0.01\end{array}$ & $\begin{array}{l}\text { rem } \\
\text { SV }\end{array}$ \\
\hline $\begin{array}{l}\text { micrograms } \\
\text { per liter }(\mu g / L) \\
\mu g / L \\
\text { milligram } \\
\text { per liter }(r, g / L) \\
m g / L \\
\rho C i / L\end{array}$ & $\begin{array}{l}1 \\
0.6757 \\
1 \\
675.7 \\
1.48\end{array}$ & $\begin{array}{l}\text { parts per billion (ppb) } \\
\mathrm{\rho Ci} / \mathrm{L} \\
\text { parts per million (ppm) } \\
\mathrm{\rho Ci} / \mathrm{L} \\
\mathrm{ppb}\end{array}$ & $\begin{array}{l}\mathrm{ppm} \\
\mathrm{pCi} / \mathrm{L} \\
\mathrm{ppb}\end{array}$ & $\begin{array}{l}1 \\
1.48 \\
1 \\
0.00148 \\
0.6757\end{array}$ & $\begin{array}{l}\mu g / L \\
\mu g / L \\
m g / L \\
m g / L \\
\rho C i / L\end{array}$ \\
\hline For Natural Uraniur & Soil & & & & \\
\hline $\begin{array}{l}\mu g / g \\
\mu g / g \\
\rho C i / g\end{array}$ & $\begin{array}{l}1 \\
0.6757 \\
1.48\end{array}$ & $\begin{array}{l}\mathrm{ppm} \\
\mathrm{pCi} / \mathrm{g} \\
\mathrm{ppm}\end{array}$ & $\begin{array}{l}\mathrm{ppm} \\
\mathrm{pCi} / \mathrm{g} \\
\mathrm{ppm}\end{array}$ & $\begin{array}{l}1 \\
1.48 \\
0.6757\end{array}$ & $\begin{array}{l}\mu g / g \\
\mu g / g \\
\rho C i / g\end{array}$ \\
\hline
\end{tabular}




\section{Executive Summary}

The Fernald site is a Department of Energy (DOE) owned facility that produced high-quality uranium metals for military defense for nearly 40 years. DOE suspended production at the Fernald site in 1989 and formally ended production in 1991. Although production activities have ceased, the site continues to examine the air and liquid pathways as possible routes inrough which pollutants from past operations and current remedial activities may leave the site.

The Fernald Site Environmental Report (SER) is prepared annually in accordance with DOE Order 5400.1, "General Environmental Protection Program." This SER covers the reporting period from January 1, 1992, through December 31, 1992, with the exception of Chapter Three, which provides information from the first quarter of 1993 as well as calendar year 1992 information. This 1992 report provides the general public as well as scientists and engineers with the results from the site's ongoing Environmental Monitoring Program. Asso included in this report are summary data of the sampling conducted to determine if the site complies with DOE, U.S. Environmental Protection Agency (USEPA), and Ohio EPA (OEPA) requirements. Finally, this report provides general information on the major waste management and environmental restoration activities during 1992.

For some readers, the highlights provided in this Executive Summary may provide sufficient information. Many readers, however, may wish to read more detailed descriptions of the information than those which are presented in this summary. All information presented in the summary is discussed more fully in the main body of the report. 


\section{Environmental Monitoring}

The Firald site's Environmentai Monitoring Program plays a key role in the effort to investigate the effects that years of operation have had on the local environment. Environmental monitoring primarily examines the air and water pathways; other program components address contamination risks associated with cleanup procedures. A summary of air and liquid pathway results is presented below.

\section{Air Pathway}

Monitoring the air pathway incorporates results from not only the air monitoring stations but also from soil, grass, produce, and milk sampling. (Although radon monitoring is part of the air pathway, it is regulated separately and, therefore, discussed separately below.) In general, the air monitoring data from 1992 were consistent with data from 1991, and all Boiler Plant emissions were well below permit limits.

Data collected from the fenceline air monitoring stations show that average concentrations of uranium were all less than $1 \%$ of the DOE standard. Airborne uranium emissions for 1992 were slightly lower than 1991 emissions.

Some onsite and nearby offsite soil samples continue to indicate elevated uranium concentrations. One offsite sampling location, in the predominant wind direction northeast of the site, had a total uranium concentration above the background level. Since airborne emissions decreased in 1992 from 1991, these increases of uranium concentrations in soil samples are a result of the deposition of airborne particles from past operations. The 1992 grass sampling results indicate that uranium concentrations are higher at fenceline and onsite locations than offsite. The elevated uranium concentrations in the soil where grass samples were collected are believed to be the source of these higher concentrations.

Uranium concentrations in produce were consistent with previous years' data. Laboratory analysis did not detect any significant differences in uranium concentrations between produce grown near the plant and produce grown at locations distant from the site.

In general, uranium concentrations from the local dairy are comparable to those from a background dairy in Indiana. However, analyses of October samples show a sudden increase in uranium concentrations at the local dairy. This incrcase was not supported by analysis of other environmental media, and uranium concentrations returned to normal the remainder of the year.

Measurements of direct radiation indicate that levels are higher near the K-65 silos as expected. However, the levels measured in 1992 are lower than 1991 levels as a result of the bentonite addition to the K-65 silos late in 1991 . 


\section{Radon Monitoring}

The average radon concentration at the fenceline during 1992 was $0.57 \mathrm{pCi} / \mathrm{L}$, lower than the 1991 average concentration and well below the DOE guideline $(3 \mathrm{pCi} / \mathrm{L})$. Of this concentration, only $0.17 \mathrm{pCi} / \mathrm{L}$ is attributable to the Fernald site. It should be noted that the average background concentration was also lower than in 1991. However, background concentrations can vary considerably from year to year due to varying meteorological conditions.

As expected, the bentonite sealant addition to the silos at the end of 1991 resulted in a significant reduction of radon concentrations measured in 1992. The average concentration at the silos including background was $0.7 \mathrm{pCi} / \mathrm{L}$, considerably less than the annual average limit of $30 \mathrm{pCi} / \mathrm{L}$.

\section{Liquid Pathway: Effluent and Surface Water}

The effluent and surface water component of the liquid pathway is monitored to determine any impacts from the Fernald site on the Great Miami River and Paddys Run. The Environmental Monitoring Program examines the effluent and surface water results, along with sediment and fish results because they are also part of the liquid pathway.

Approximately $436 \mathrm{~kg}$ ( 961 pounds) of uranium were discharged to the Great Miami River during 1992, a reduction of more than $30 \%$ as compared to 1991 . This discharge, however, resulted in a slight increase in downriver uranium concentrations from the upriver locations. The downriver concentrations were consistent with 1991 downriver concentrations. The uranium concentrations in Paddys Run continued to show effects of stormwater runoff from the site. Although the average uranium concentration at the nearest offsite sampling location was just slightly higher than in 1991 , it was only $1.2 \%$ of the DOE guideline.

Sediment sampling during 1992 showed radionuclide concentrations in the Great Miami River and Paddys Run to be consistent with previous years' data and did not indicate a build-up of radioactive pollutants in the sediment. Also in 1992, uranium concentrations in fish caught downstream of the site's effluent line were no greater than in those fish caught upstream.

The National Pollutant Discharge Elimination System (NPDES) permit specifies sampling locations, sampling and reporting schedules, discharge limits, water quality standards, and other restrictions on the Fernald site's effluents discharged to the Great Miami River and Paddys Run. The site complied with NPDES discharge limits $99.7 \%$ of the time during 1992 . Out of the 6,190 samples taken during 1992 , only 16 samples (all onsite) were not in compliance. Concentrations of fluoride, nitrate-nitrogen, and $\mathrm{pH}$ values in the river showed little or no effect from Fernald site operations on surface water quality. All results were within acceptable limits. 


\section{Liquid Pathway: Groundwater}

The Fernald site carefully monitors the groundwater beneath and in the vicinity of the site for more than 50 radioactive and nonradioactive pollutants to identify and track the movement of pollutants which may be present in the Great Miami Aquifer.

Site personnel monitored 37 private wells for 16 different metals. Iron and manganese were found in many wells. However, these detections are not unusual for an area, such as the Fernald area, with high natural concentrations of these metals. Site personnel also monitored these wells for uranium. Only four private wells had average concentrations of uranium above the proposed USEPA standard of $13.5 \mathrm{pCi} / \mathrm{L}$.

Groundwater analyses for nonradiological parameters showed that metals and volatile organic compounds (VOCs) are restricted, for the most part, to the waste pits and the former production area onsite.

The Comprehensive Groundwater Monitoring Program sampled for total uranium at 216 on- and offsite wells. Of the 844 analyses, 85 showed concentrations above the proposed USEPA standard of $13.5 \mathrm{pCi} / \mathrm{L}$. All offsite locations were in the South Plume area. This area of contamination is being addressed by the South Groundwater Contamination Plume Removal Action as part of the Remedial Investigation and Feasibility Study.

This comprehensive program also samples for Primary and Secondary Drinking Water Standards. Seven of the 26 primary constituents were detected above the standards in more than one well, and one showed an isolated detection in a single well. Detections above the secondary standards for iron, manganese, sulfate, and total dissolved solids were found in several wells. Many secondary constituents are naturally occurring, and their presence does not pose a threat to human health or the environment except at considerably higher concentrations.

\section{Estimated Radiation Doses for 1992}

Scientists calculate potential radiation doses to nearby residents by entering offsite radionuclide concentrations, which are determined through environmental monitoring and sampling, into mathematical models.

In 1992, the hypothetical maximally exposed individual living nearest the Fernald site, exclusively consuming local foodstuffs and fish, along with drinking Great Miami River water, could have received a maximum committed effective dose of $1.0 \mathrm{mrem}$. (This dose is exclusive of the dose received from radon.) This dose can be compared to the limit of 100 mrem for all pathways (also exclusive of radon) that was established by the International Commission on Radiological Protection and adopted by DOE. 


\section{Dose Attributable to Radon}

Of the $0.57 \mathrm{pCi} / \mathrm{L}$ radon concentration me'ssurec $-t$ the Fernald site fenceline in 1992 , only $0.17 \mathrm{pCi} / \mathrm{L}$ is attributable to the site (the remainder is background). The committed effective dose for a concentration of $0.17 \mathrm{pCi} / \mathrm{L}$ is approximately 51 mrem. This dose is in addition to the dose received from naturally occurring radon, which is nearly 200 mrem per year.

\section{Environmental Remediation}

Since the formal end of production at the Fernald site in 1991, the site's efforts have concentrated on environmental remediation. The site's Waste Management Program and the Remedial Investigation and Feasibility Study (RI/FS) process are the two main Fernald site activities geared toward remediation.

\section{Waste Management Activities}

The Waste Management Program generally seeks to characterize, store, treat (as necessary), and dispose of radioactive, hazardous, mixed, and conventional industrial waste from the site in a safe and environmentally sound manner while complying with all applicable regulations. Also, the Waste Minimization Program seeks to include waste minimization planning and concepts into each activity and minimize any secondary wastes resulting from the site remediation activities.

The Fernald site made significant advances in its waste management activities in 1992. During 1992, approximately 92,500 drum equivalents (DEs) of low-level waste were shipped to the Nevada Test Site (NTS) for disposal. Also, for the first time, the site shipped thorium wastes to NTS.

The Fernald site continued work on the final stage of a three-project plan to improve the temporary storage conditions for the onsite thorium inventory. This plan significantly reduces the potential for any accidental release of thorium through structural failure or a deteriorating container and reduces radiation exposure to site workers.

\section{Remedial Investigation and Feasibility Study}

In order to remediate facilities such as waste pits, sludge ponds, groundwater, storage silos, and process buildings, the Fernald site began its RI/FS in 1986. The RI/FS process is outlined by the Comprehensive Environmental Response, Compensation, and Liability Act (CERCLA) legislation and is conducted according to USEPA regulations. The process provides a list of alternatives as well as a mechanism for choosing an alternative for remediation. The final choice is reviewed by the public and approved by USEPA. 
The RI/FS divides facilities that are to be cleaned up into operable units. There are five operable units at the Fernald site and a sixth Sitewide Operable Unit. The Sitewide Operable Unit encompasses the five other operable units and ensures that actions taken under them are protective of human health and the environment on a sitewide basis. Cleanup activities at the site continue according to schedules and specifications contained in the 1991 Amended Consent Agreement.

As of the end of 1992, the Fernald site had identified 27 removal actions designed to accelerate cleanup. Four of these removal actions were completed prior to 1992. During 1992, five more removal actions were completed. They are the:

- Waste Pit Area Runoff Control Removal Action (Operable Unit 1),

- Pit 5 Experimental Treatment Facility Removal Action (Operable Unit 1),

- Active Flyash Pile Controls Removal Action (Operable Unit 2),

- Inactive Flyash Pile Removal Action (Operable Unit 2), and

- Expedited Silo 3 Dust Collector Removal Action (Operable Unit 4).

Several other removal actions are well underway at the Fernald site, and others are still in the planning stages. As remedial activities continue at the site, releases of pollutants to the environment are inevitable. However, the removal actions are designed to keep the potential effects on human health and the environment to a minimum. The Environmental Monitoring Program will subsequently continue to monitor for the potential effects of these activities. 


\section{Introduction to the Site}

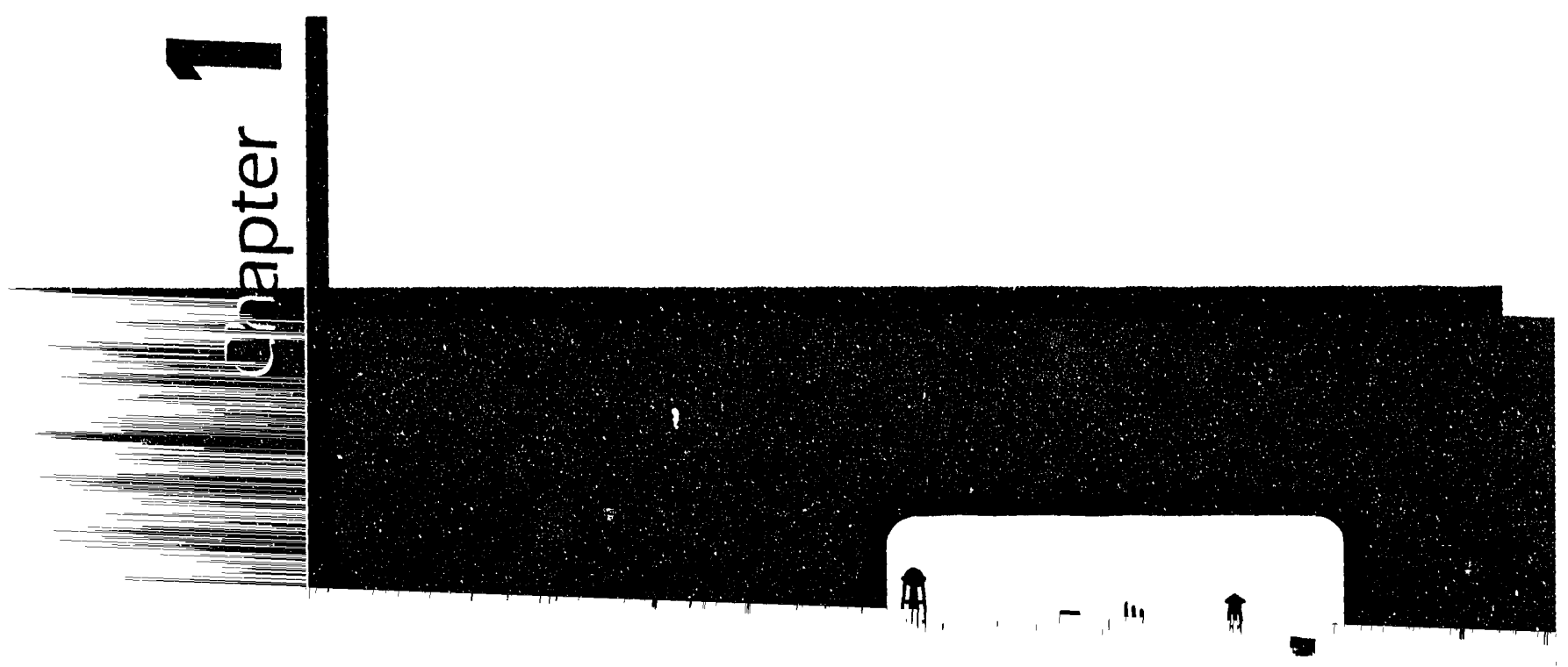




\section{Introduction to the Site}

Today, the Fernald site, which is owned by the Department of Energy (DOE). focuses extensively on environmental restoration. Scientists closely investigate the site, a former uranium metals processing facility, and surrounding contaminated areas, and they develop remedial techniques.

This Fernald Site Environmental Report (SER) documents the results of the Environmental Monitoring Program for calendar year 1992. In accordance with DOE Order 5400.1, "General Environmental Protection Program," the information in the 1992 SER is current from January 1, 1992, through December 31. 1992, with the exception of the Environmental Compliance Summary. This summary is updated through April 1, 1993. In order to put the material presented in this report into perspective, Chapter One contains the following introductory sections:

- The Fernaid Site Mission: Environmental Compliance and Restora tion, an historical overview of the site's former operations and its current cleanup mission leading to current site activities, including the evolution of the Environmental Monitoring Program;

- Local Geography, an introduction to the physical, ecological, and human characteristics of the area;

- Exposure Pathways to Humans, an examination of the physical and biological surroundings as possible routes for contaminants to reach local communities; and

- Environmental Standards and Guidelines, a description of the various standards with which the Fernald site must comply to protect the local environment. 


\section{The Fernald Site Mission: Environmental Compliance and Restoration}

In recent years, the mission at the Fernald site has become one of environmental compliance and restoration. However, when the site was established in the early 1950 s, its primary mission was to produce uranium metal.

Shortly after the end of World War II, the United States recognized a need for new facilities to produce uranium metal in support of defense activities. Existing facilities, developed for the war effort, were neither economical to operate nor able to meet increasing demands. The Atomic Energy Commission (AEC) required an increase in the quality and quantity of uranium metal as well as improvements in the control and safety of production operations.

After evaluating several sites, the government selected a 425-hectare (1,050-acre) area, about $27 \mathrm{~km}$ (17 miles) northwest of downtown Cincinnati, Ohio as the site for a new production facility (see Figure 1). This facility was sited just north of Fernald, Ohio, a small farming community. Ground was broken on May 16, 1951, and the first uranium derby was produced at the site's Pilot Plant on October 11, 1951. The major portion of construction was completed by 1954 .

In general, the relative importance and corresponding funding of the former production and environmental activities reflect the course of U.S. Defense history

\section{ENMRONMENTAL RESTORATON MANAGEMENT CONIRACT}

In order to facilitate an effective and efficient cleanup of the Femald site, DOE replaced the site's Management and $O p$ erating contract with an Environmental Restoration Manage. ment Contract (ERMC). Beginning in early 1992, DOE began its search for companies to bid on the ERMC. Westinghouse Environmental Management Company of Ohio (WEMCO). which had managed the site since 1986, opted not to bid on the contract.

The ERMC was to be awarded in June 1992. However, DOE issued an extension, and the decision was not made until the end of August. At that time, DOE awarded the contract to a team led by Fluor-Daniel, including lacobs Engineering. NUS, and Nuclear Fuel Services. This is the first contractor at the site selected specifically for environmental restoration.

A three-month transition period began in September for Fernald Environmental Restoration Management Corporation (FERMCO), a wholly-owned subsidiary of Fluor-Daniel, At the same time, DOE extended the WEMCO contract through November 1992 to ensure a smooth transition. FERMCO assumed full contractual responsibility for the Fernald site in December under a five-year contract. from the end of World War II until today. Uranium-metal production reached a peak during the height of the Cold War in the 1950s and 1960s. During the late 1970s, funding for production and supporting organizations, including environmental monitoring, was significantly reduced, subsequently reducing supporting activities. Production accelerated again in the early 1980s, when the United States increased Defense spending, and production at the facility accelerated. By the late 1980s, however, an increasing demand for environmental accountability, combined with a decreasing demand for uranium metal at other DOE facilities, influenced the site to change its mission from uranium production to environmental restoration. 
Figure 1: Fernald Site and Vicinity

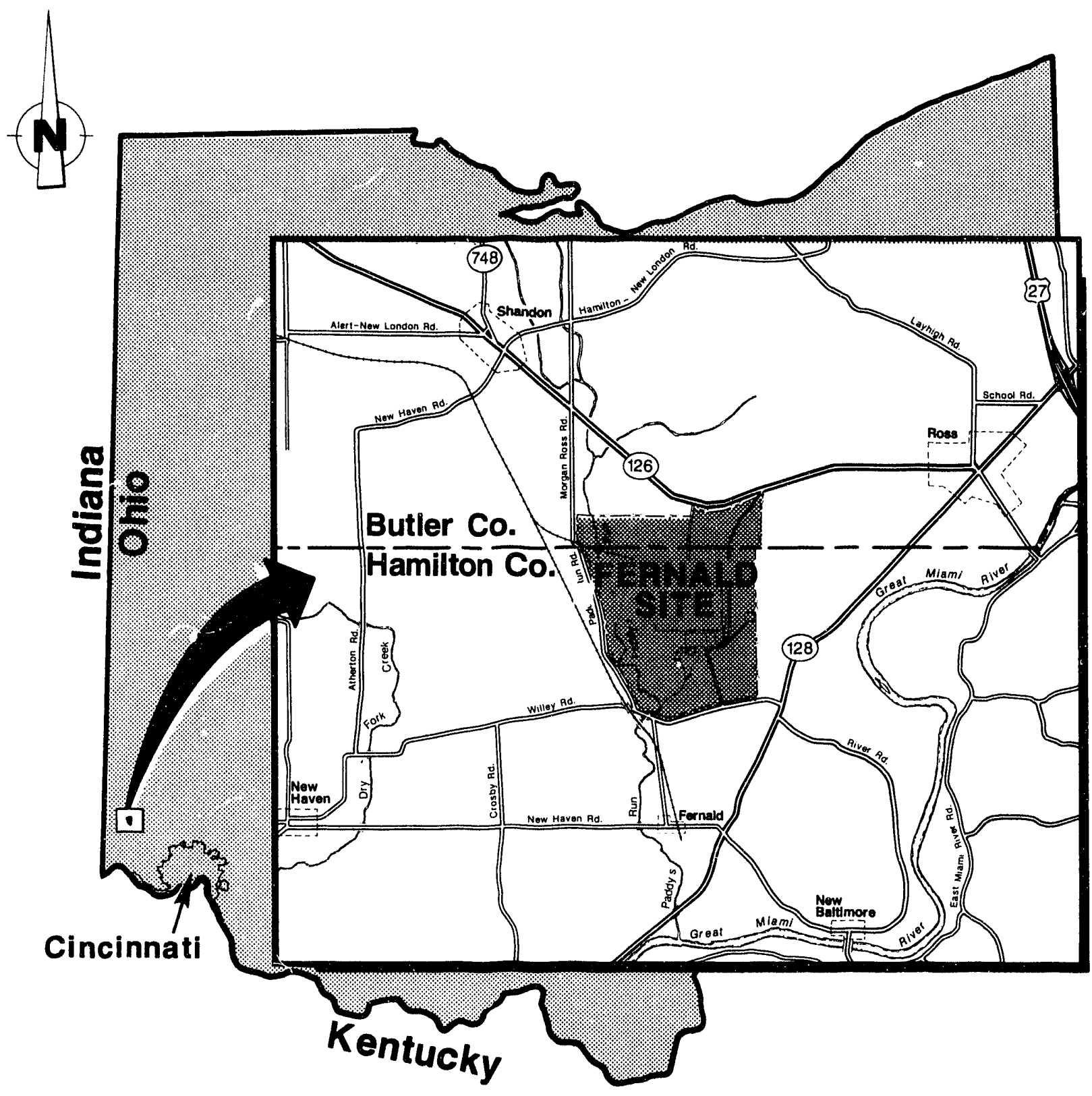

The Fernald Site covers about 425 hectares (1,050 acres). 
Production was suspended in July 1989. In October 1990, DOE transferred management responsibility for the site from its Defense Programs organization to the Office of Environmental Restoration and Waste Management. In February 1991, DOE announced its intention to formally end the production mission and submitted a closure plan to Congress, which becamu effective in June 1991.

\section{An Overview of Former Production Operations}

Although production at the Fernald site ended in 1989, a brief overview of the production process will provide the reader with a perspective on the ongoing Environmental Monitoring Program and other environmental investigations. The major steps in the production process are highlighted in Figure 2. A variety of materials were used in the process, including many that were received from other DOE sites. In fact, materials such as floor sweepings, dust collector residues, and production residues were recycled in order to recover as much uranium as possible.

The first production steps involved chemical processing that ended with an intermediate product commonly called "green salt" (uranium tetrafluoride, $\mathrm{UF}_{4}$ ). The green salt was then blended with magnesium-metal granules, placed in a closed reduction pot,

\section{DePLeted and EnRICHED URANIUM}

Most of the uranium processed in more recent years at the site was depleted in the uranium -235 isotope; that is, it contained a smaller percentage of uranium-235 than does naturally occurring ura nium-less than $0.71 \%$. lisotopes are discussed in Chapter Two, Fundamentals of Radiation and Health Hazards.) For many years, much of the uranium processed was slightly enriched $-0.71 \%$ to $2 \%$ uranium -235 . and heated in furnaces in Plant 5 (see Figure 3).

The product of this operation was uranium metal called a "derby."

Some derbies were sent directly to other DOE sites, while the site remelted the remainder, along with uranium scrap-metal recovered from earlier production, and poured them into graphite molds to form ingots. Ingots varied in weight, size, and shape according to how they were used at this and other DOE sites. Machining of these ingots occurred in plants 6 and 9, after which the billets (machined ingots) were shipped to other DOE sites, principally the Savannah River Site in South Carolina and the Hanford Site in Richland, Washington. 


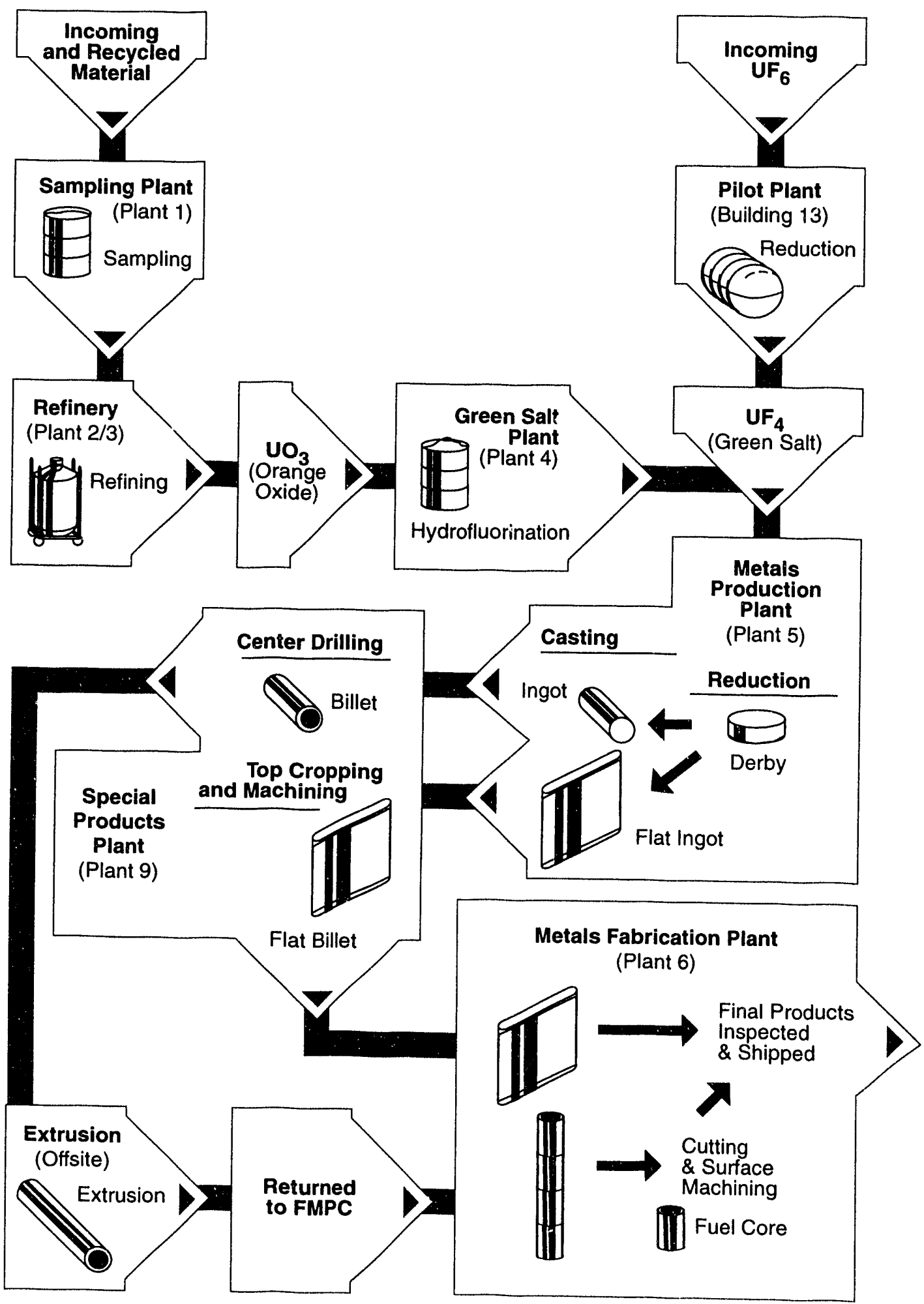


Figure 3: Fernald Site Perspective

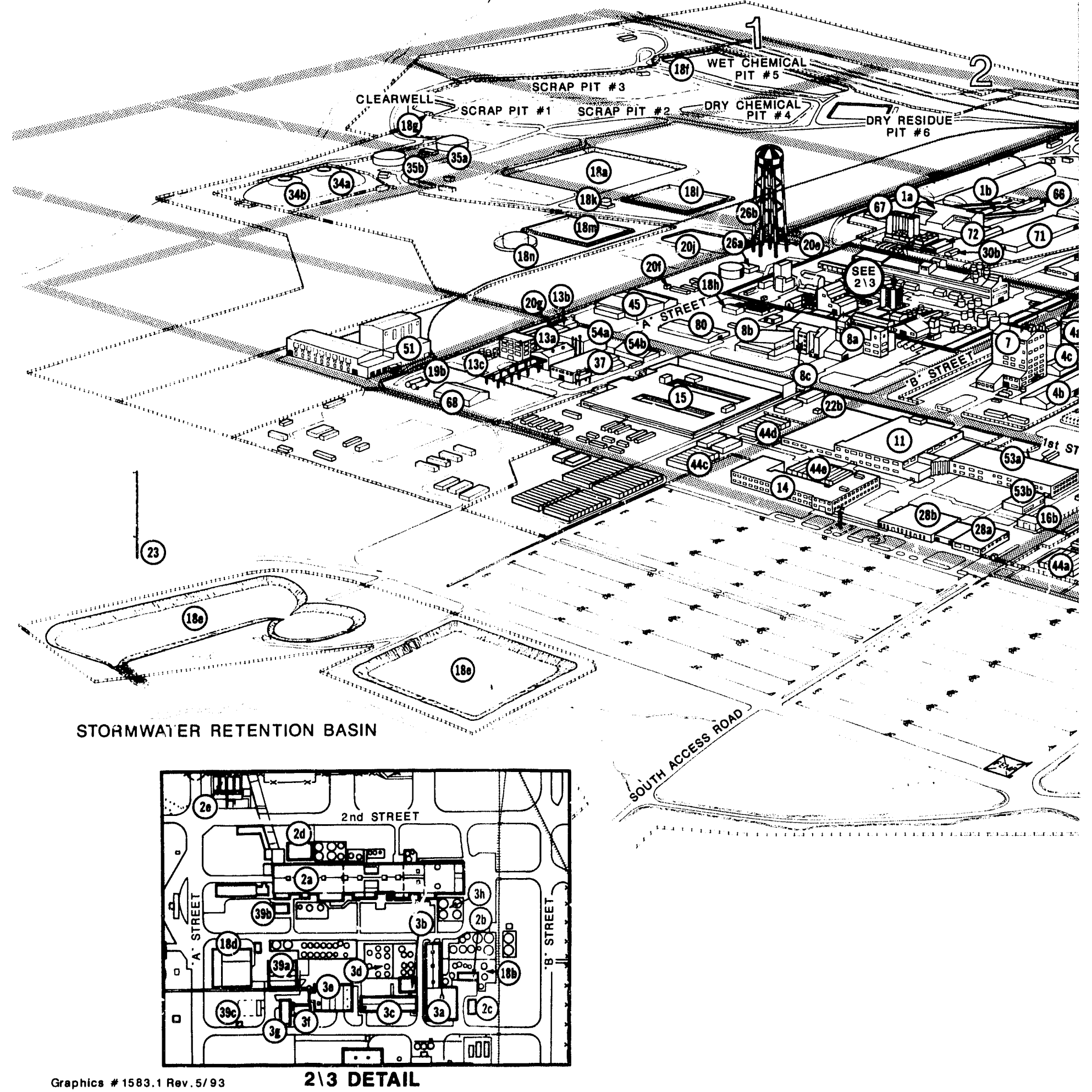




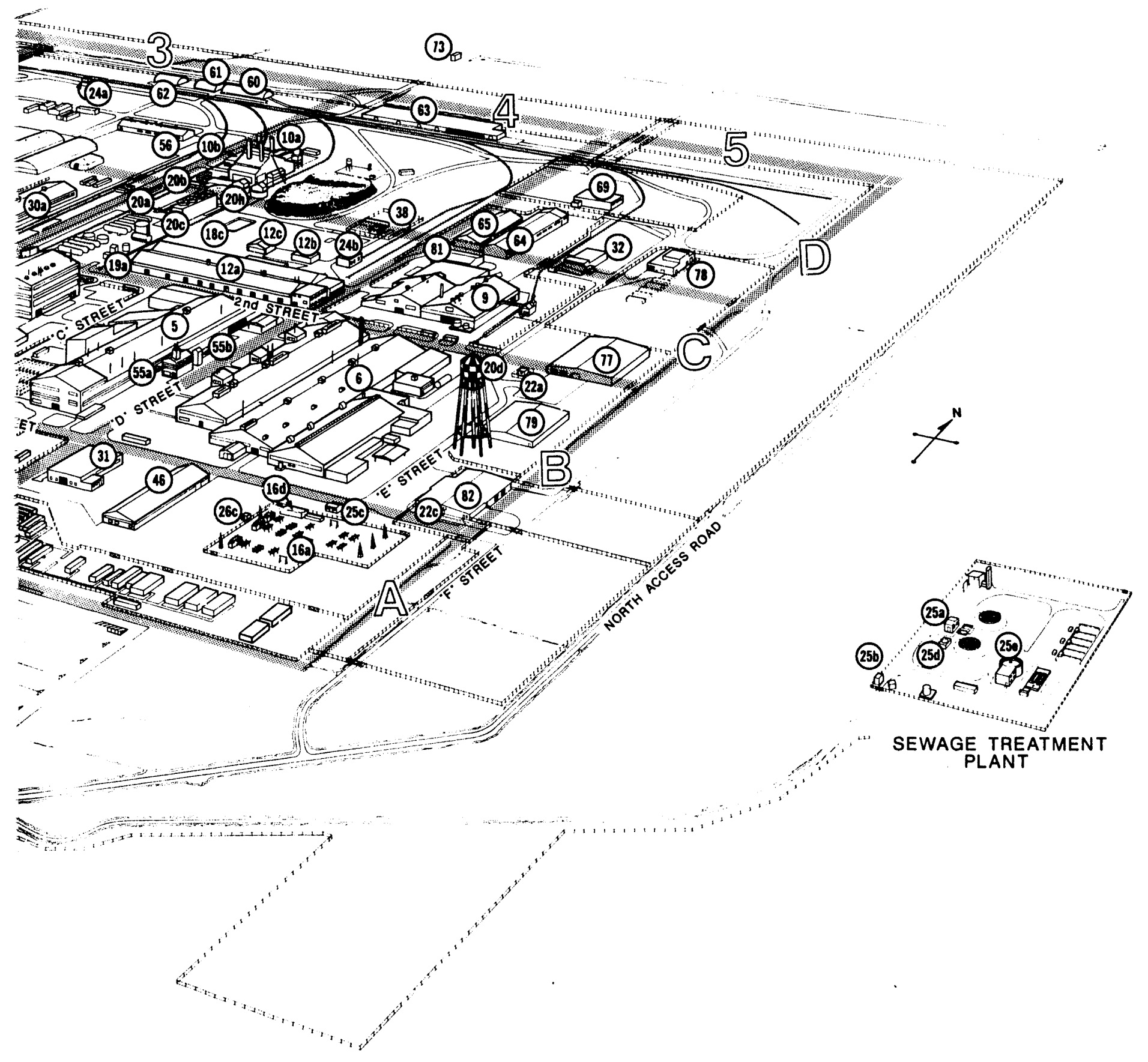




\section{Building Identification}

\begin{tabular}{|c|c|c|c|c|c|}
\hline $\begin{array}{l}\text { Building } \\
\text { ID No. }\end{array}$ & $\begin{array}{l}\text { Grid } \\
\text { Coordinates }\end{array}$ & Title & $\begin{array}{l}\text { Building } \\
\text { ID No. }\end{array}$ & $\begin{array}{l}\text { Grid } \\
\text { Coordinates }\end{array}$ & Title \\
\hline 00 & $\star \star$ & General & $22 c$ & $A-5$ & Truck Scale \\
\hline $1 a$ & $C-3$ & Preparation Plant & 23 & * & Meteorological Tower \\
\hline ib & $C-3$ & Plant I Storage Building & $24 a$ & $D-3$ & Railroad Scale House \\
\hline $2 a$ & $B-3$ & Ore Refinery Plant & $24 b$ & $C-4$ & Railroad Engine Building \\
\hline $2 \mathrm{~b}$ & B-3 & Lime Handling Building & $25 a$ & * & Chlorination Building \\
\hline $2 \mathrm{C}$ & B-3 & Bulk Lime Handling Building & $25 b$ & $\star$ & Manhole-175 \\
\hline $2 d$ & $B-3$ & Metal Dissolver Building & $25 c$ & $A-5$ & Sewage Lift Station Building \\
\hline $2 \mathrm{e}$ & $C-3$ & NFS Storage and Pump House & $25 d$ & * & U.V. Disinfection Building \\
\hline $3 a$ & B-3 & Maintenance Building & $25 \mathrm{e}$ & $\star$ & Digester Control Building \\
\hline $3 b$ & B-3 & Ozone Building & $26 a$ & B-3 & Pump House - H.P. Fire Protection \\
\hline $3 c$ & $B-3$ & Control House & $26 b$ & B-3 & Elevated Water Storage Tank \\
\hline $3 d$ & B-3 & NAR Towers & $28 a$ & $A-4$ & Security Building \\
\hline $3 e$ & $B-3$ & Hot Raffinate Building & $28 \mathrm{~b}$ & A-4 & Human Resources Building \\
\hline $3 f$ & $B-3$ & Digestion Fume Recovery & $30 a$ & $C-3$ & Chemical Warehouse \\
\hline $3 g$ & B-3 & Refrigeration Building & $30 \mathrm{~b}$ & $C-3$ & Drum Storage Warehouse \\
\hline $3 h$ & $\mathrm{~B}-3$ & Refinery Sump & 31 & A-5 & Engine House - Garage \\
\hline $4 a$ & B-4 & Green Salt Plant & 32 & D-5 & Magnesium Storage \\
\hline $4 b$ & $B-4$ & Plant 4 Warehouse & $34 a$ & $B-1$ & K-65 Storage Tank - North \\
\hline $4 c$ & B-4 & Plant 4 Maintenance Building & $34 b$ & $B-1$ & K-65 Storage Tank - South \\
\hline 5 & B-4 & Metals Production Plant & $35 a$ & $\mathrm{C}-1$ & Metal Oxide Storage Tank - North \\
\hline 6 & B-5 & Metals Fabrication Plant & $35 b$ & B-1 & Metal Oxide Storage Tank - South \\
\hline 7 & B-4 & Plant 7 & 37 & A-3 & Pilot Plant Annex \\
\hline $8 a$ & $B-3$ & Recovery Plant & 38 & D-4 & Propane Storage \\
\hline $8 b$ & $B-3$ & Maintenance Building & $39 a$ & B-3 & Incinerator Building \\
\hline $8 c$ & B-3 & Rotary Kiln/Drum Reconditioning & $39 b$ & $\mathrm{~B}-3$ & Shelter Storage Building \\
\hline 9 & $C-5$ & Special Products Plant & $39 c$ & $B-3$ & Incinerator Building Sprinkler \\
\hline $10 a$ & D-4 & Boiler Plant & & & Riser House \\
\hline $10 \mathrm{~b}$ & D-4 & Boiler Plant Maintenance Building & $44 a$ & A-5 & Trailer Complex - 6-Plex (East) \\
\hline 11 & A-4 & Service Building & $44 c$ & $A-3$ & Trailer Complex - 7-Plex (South) \\
\hline $12 a$ & $C-4$ & Maintenance Building (Main) & $44 d$ & $A-3$ & Trailer Complex - 7-Plex (North) \\
\hline $12 \mathrm{~b}$ & $C-4$ & Cylinder Storage Building & $44 \mathrm{e}$ & A-4 & Trailer Complex - 10-Plex \\
\hline $12 c$ & $C-4$ & Lumber Storage Building & 45 & B-3 & Rust Engineering Building \\
\hline $13 a$ & A-3 & Pilot Plant Wet Side & 46 & A-5 & Heavy Equipment Garage \\
\hline $13 \mathrm{~b}$ & $A-3$ & Pilot Plant Maintenance Building & 51 & $A-2$ & $\mathrm{UF}_{6}$ to $\mathrm{UF}_{4}$ Reduction Facility 11 \\
\hline $13 c$ & $A-3$ & Sump Pump House & $53 a$ & $A-4$ & Occupational Safety \& Health \\
\hline 14 & A-4 & Administration Building & $53 \mathrm{~b}$ & A-4 & In-Vivo Building \\
\hline 15 & $A-3$ & Laboratories & $54 a$ & $A-3$ & UF to UF ${ }_{4}$ Reduction Facility 1 \\
\hline $16 a$ & $A-5$ & Main Electrical Station & $54 b$ & $A-3$ & Pilot Plant Warehouse \\
\hline 160 & $A-4$ & Electrical Substation & $55 a$ & $B-4$ & Slag Recycling Plant \\
\hline $18 a$ & $C-2$ & Biodenitrification Surge Lagoon & $55 b$ & B-4 & Slag Recycling Pit/Elevator \\
\hline $18 \mathrm{~b}$ & B-3 & General Sump & 56 & D-3 & CP Storage Warehouse \\
\hline $18 \mathrm{c}$ & $C-4$ & Coal Pile Runoff Basin & 60 & D-3 & Quonset Hut \#1 \\
\hline $18 d$ & $\mathrm{~B}-3$ & Biodenitrification Towers & 61 & D-3 & Quonset Hut \#2 \\
\hline $18 \mathrm{e}$ & $\star$ & Stormwater Retention Basin & 62 & D-3 & Quonset Hut \#3 \\
\hline $18 f$ & $D-1$ & Pit 5 Sluice Gate & 63 & $D-4$ & $\mathrm{KC}-2$ Warehouse \\
\hline $18 q$ & $C-1$ & Clearwell Pump House & 64 & D-5 & Thorium Warehouse \\
\hline $18 \mathrm{~h}$ & B-3 & BDN Effluent Treatment Facility & 65 & D-5 & (Old) Plant 5 Warehouse \\
\hline $18 \mathrm{k}$ & B-2 & Methanol Tank & 66 & $C-3$ & Drum Reconditioning Building \\
\hline 181 & $C-2$ & Low Nitrate Tank & 67 & $c-3$ & Plant I Thorium Warehouse \\
\hline $18 m$ & $B-2$ & High Nitrate Tank & 68 & $A-3$ & Pilot Plant Warehouse \\
\hline $18 n$ & $\mathrm{~B}-2$ & High Nitrate Storage Tank & 69 & D-5 & Decontamination Building \\
\hline $19 a$ & $C-4$ & Main Metal Tank Farm & 71 & $c-3$ & General In-Process \\
\hline 190 & $A-3$ & Pilot Plant Ammonia Tank Farm & & & Storage Warehouse \\
\hline $20 a$ & $C-4$ & Pump Station and Power Center & 72 & $\mathrm{C}-3$ & Drum Storage Building \\
\hline $20 \mathrm{~b}$ & D-4 & Water Flant & 73 & * & Fire Brigade Training \\
\hline $20 c$ & $\mathrm{C}-4$ & Cooling Towers & & & Center Building \\
\hline $20 d$ & $B-5$ & $\begin{array}{l}\text { Elevated Storage Tank } \\
\left.\text { (Potable } \mathrm{H}_{2} \mathrm{O}\right)\end{array}$ & $\begin{array}{l}77 \\
78\end{array}$ & $\underset{\star}{C .5}$ & $\begin{array}{l}\text { Finished Products Warehouse } \\
\text { New D\&D Facility }\end{array}$ \\
\hline $20 \mathrm{e}$ & B-3 & Well House \#1 & 79 & B-5 & Plant 6 Warehouse \\
\hline $20 f$ & $B-3$ & Well House \#2 & 80 & $B-3$ & Plant 8 Warehouse \\
\hline 200 & A-3 & Well House \#3 & 81 & $C-5$ & Plant 9 Warehouse \\
\hline $20 \mathrm{~h}$ & D-4 & Process Water Storage Tank & 82 & B-5 & Receiving \& Incoming \\
\hline $20 j$ & $B-2$ & Lime Slurry Pits & & & Materiais Inspection Area \\
\hline $22 a$ & B-5 & Gas Meter Building & \multirow{2}{*}{\multicolumn{3}{|c|}{ * Outside of Perimeter Security Fence }} \\
\hline $22 \mathrm{~b}$ & $A-3$ & Storm Sewer Lift Station & & & \\
\hline
\end{tabular}




\section{Handling and Storing Radioactive and Hazardous Materials}

Although the Fernald site no longer produces uranium metal, it continues to store materials once used here and at other DOE sites. Some of the radioactive and hazardous materials that were handled or stored onsite during 1992 include:

\section{Radioactive}

- Magnesium fluoride $\left(\mathrm{MgF}_{2}\right)$ contaminated with uranium,

- Pitchblende ore residues containing radium stored in the K-65 silos,

- Radioactive materials in the waste pits,

- Scrap metal contaminated with uranium compounds,

- Thorium and thorium compounús siored within the production area,

- Uranium compounds, and

- Uranium metal.

\section{Hazardous}

- Heavy metals,

- Hydrochloric acid,

- Laboratory chemicals,

- Methanol,

- Nitric acid,

- Process waste,

- Sodium hydroxide, and

- Sulfuric acid.

The site is renovating and adding buildings to store hazardous waste, repackaging some materials into new drums, and removing materials no longer needed since production has ended. For example, thorium previously stored in a deteriorating above-ground silo, in bins, and in drums on an outdoor pad has been repackaged in new drums and stored in a warehouse. The Fernald site has significantly reduced its inventory of chemicals once used for production by disposing of them at designated waste disposal facilities.

\section{Purpose of the Environmental Monitoring Program}

As a result of the continued onsite storage of radioactive and hazardous waste, federal and state waste management requirements that were applied during the site operation period are still in effect. Earlier regulations were much less stringent, and the effects of past operations are still evident. Today, Fernald site personnel continue to investigate these effects on the environment. The Environmental Monitoring Program plays a key role in this effort. Like any complex program or investigation, the Environmental Monitoring Program was developed after careful consideration of many components. For example, former site production processes, which involved 
both radioactive and nonradioactive materials, resulted in air and liquid discharges to the environment. The monitoring program is largely based upon the flow of these materials through the air and liquid pathways. Additional program components address contarnination risks associated with cleanup procedures.

Environmental monitoring activities seek to determine the amount of radioactive and nonradioactive materials that leave the site and enter the surrounding environment. In short, this year-round Environmental Monitoring Program is designed to:

- Ensure that the site will detect any unusual release of materials as quickly as possible so that corrective actions can be taken,

- Closely monitor releases to ensure that air emission and liquid effluent standards and guidelines are not exceeded,

- Evaluate the impact of operations (past and present) on the environment,

- Estimate the radiation dose that area residents may be exposed to as a result of former production operations and current cleanup activities at the site, and

- Measure progress in correcting problems from past operations and in implementing improved environmental management practices.

This type of environmental monitoring report has been published for the site since 1960. It is required by DOE Order 5400.1, "General Environmental Protection Program."' The 1992 SER:

- Focuses on the results of the site's ongoing Environmental Monitoring Program;

- Reports summary data of the sampling conducted to determine whether the site complies with DOE, U.S. Environmental Protection Agency (USEPA), and Ohio EPA (OEPA) requirements; and

- Provides general information on the major waste management and environmental restoration activities during 1992.

\section{Local Geography}

A variety of regional physical, ecological, and human characteristics form the context in which environmental monitoring results must be analyzed. By studying various elements of the local geography, scientists and engineers are better able to identify the impact of former production activities. Remedial techniques are then designed to restore the physical environment to its original state or to an established cleanup standard. The following sections describe several of these characteristics, beginning with the geologic origins of the area.

\section{Geologic History}

About 450 million years ago (in the Late Ordovician period), sediments were deposited in a shallow sea. These sediments solidified over time to become predominantly shale with alternating thin layers of limestone, strata known universally as the Cincinnatian Series. The shale is the relatively impermeable bedrock underlying the site. 
An ancient river cut into the shale bedrock to about 60 meters ( 200 feet) below the present-day Great Miami River, forming a channel named the New Haven Trough. Later, the Illinoisan and Wisconsin glaciers (about 40,000 years ago and 10,000 years ago, respectively) advanced into the area during the Pleistocene epoch. These glaciers crushed rocks as the ice moved southward from the arctic region. As the glaciers receded, they filled the trough with sand and gravel sediments. ${ }^{2}$

The last of the glaciers in the Fernald area deposited a relatively impermeable glacial till over the sands and gravel. A mix of clay, silt, sand, gravel, and cobbles, this glacial till is unevenly deposited throughout the area and makes up the local overburden.

The Great Miami River and its tributaries have eroded significant portions of the overburden and left terrace remnants which stand higher than surrounding bottom lands of the river valley. The Fernald site lies on top of one of these terrace remnants, about 177 meters ( 580 feet) above sea level. The property rises to 213 meters (700 feet) at the northern boundary of the site and slopes downward to 168 meters (550 feet) at Paddys Run. North and south-southwest of the site, the hills peak at about 260 meters ( 850 feet) and 235 meters ( 770 feet), respectively. The elevation of the Great Miami River, east of the site, is about 165 meters (540 feet), while the land rises gently to about 183 meters (600 feet) west of the site. Figure 4 presents a cross section of the area.

\section{Lithology}

Lithology is the study, classification, and mapping of rocks and rock formations. This science is vital in determining the location, flow, and direction of groundwater. The shale underlying the site forms the floor and valley walls of the New Haven Trough and is generally between 18 and 60 meters ( 60 and 200 feet) below the ground surface. The elevation of the bedrock surface varies from 100 meters (330 feet) above sea level south of the production area to 122 meters ( 400 feet) just north of the site. ${ }^{3}$

Sand and gravel filling the New Haven Trough are up to 60 meters (200 feet) thick. This relatively porous material makes up the Great Miami Aquifer. About 30 to 38 meters ( 100 to 125 feet) below the surface of the Fernald site, the sand and gravel is divided by a greenish-black silty clay layer, about 3 to 6 meters (10 to 20 feet) thick. ${ }^{3.4}$ Data collected as part of the ongoing Remedial Investigation and Feasibility Study (RI/FS) suggest that the clay layer extends from west of Paddys Run to the center of the production area and is present beneath the waste pit area. The clay layer does not extend east or south of the production area.

A silty clay glacial till overlies the sand and gravel aquifer. This dense overburden, ranging in thickness between 6 and 15 meters (20 and 50 feet), varies in composition both vertically and horizontally. The elevation of the base of the overburden is 165 
Figure 4: Cross-Section of the New Haven Trough, Looking North

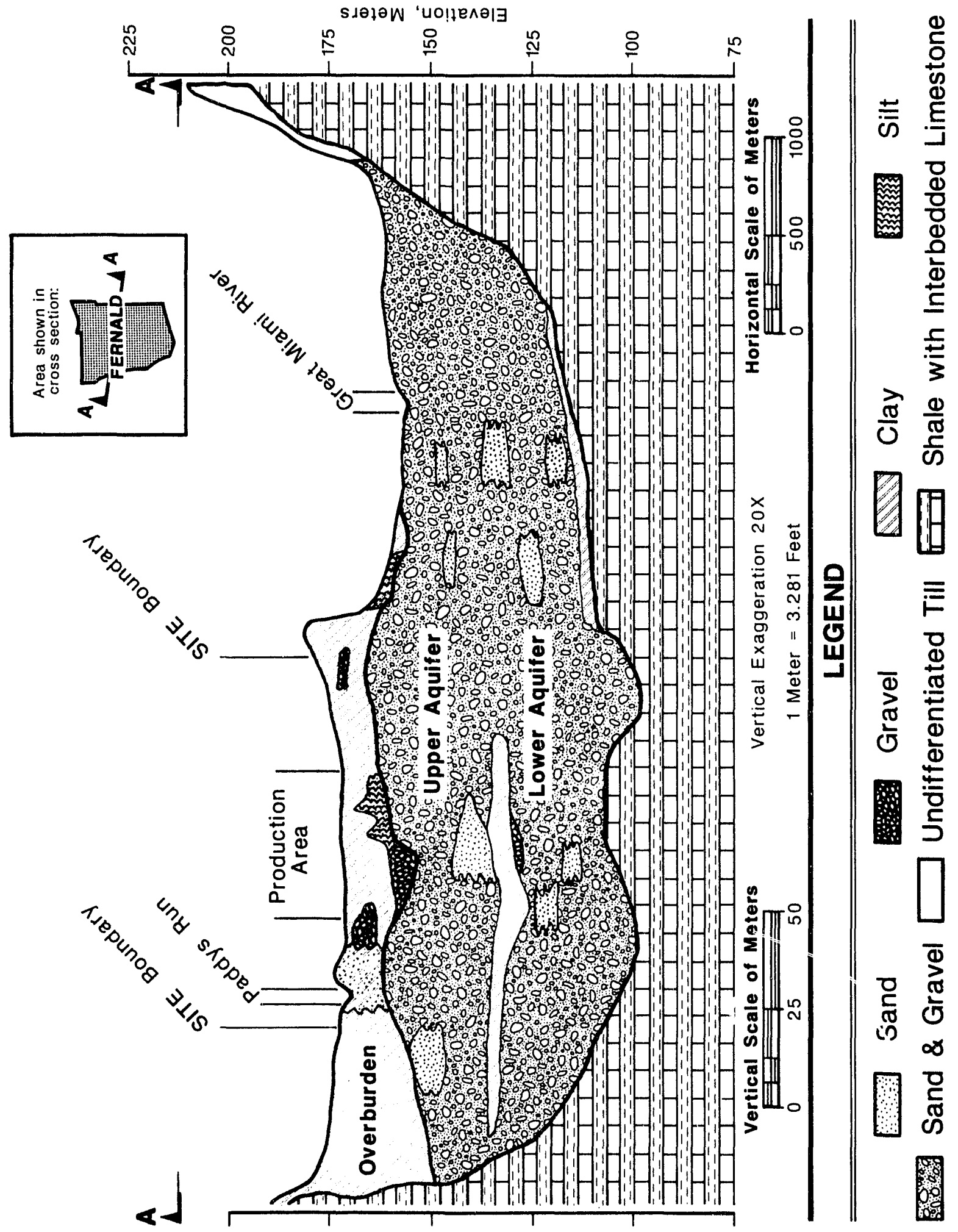


meters (540 feet) above sea level. ${ }^{3,4.5}$ The silty clay overburden continues north and east of the site, where it rests upon the shale bedrock. However, in the lower reaches of Paddys Run and the outfall ditch, the clay has eroded, exposing the underlying sand and gravel and giving the aquifer direct contact with surface runoff.

\section{Groundwater Hydrology}

Hydrology is the study of the properties, distribution, and circulation of water through the local environment. Surface hydrology, discussed in the next section, is the study of drainage systems like rivers, streams, and rainwater runoff. Groundwater hydrology, discussed here, focuses on the movement of water below the earth's surface.

Groundwater beneath the site exists in the glacial overburden as perched water in a sand and gravel aquifer and, to a much lesser extent, in the underlying bedrock. Perched water occurs when water sinking through the earth from the surface is trapped above very dense clay. Some of this perched water may slowly seep through the clay, but most remains trapped. At the Fernald site, perched water is generally found between 0.3 and 3 meters ( 1 to 10 feet) below the surface. Perched water in the glacial overburden occurs sporadically and is not a sufficient source of drinking water. In the overburden, water does not move as easily as water in the sand and gravel aquifer below since most perched water occurs in isolated pockets. ${ }^{6}$

Water sinking through the glacial overburden quickly collects in the sand and gravel aquifer, saturating it. Most water is prevented from sinking further by the nearly impermeable rock floor. The top of the aquifer is about 25 meters ( 82 feet) beneath the site, and the aquifer is between 38 and 53 meters ( 125 and 175 feet) thick. As shown in Figure 5, the groundwater in the sand and gravel aquifer is moving east under the waste pit and production areas, while on the southern edge of the facility, groundwater moves generally to the south. These groundwater flow data are used to track and forecast the movement of contaminants which may be found in the aquifer.

There may be groundwater even deeper in the slightly permeable rock layers below the sand and gravel aquifer; however, this water is essentially trapped in cracks and fissures and does not contribute any significant amount to the entire flow system.

\section{Surface Hydrology}

The Fernald site is part of the Great Miami River drainage basin, although it is above the floodplain (see Figure 6). Natural drainage from the Fernald site to the Great Miami River is primarily via Paddys Run, a small creek which begins north of the site and flows southward along the western edge of the site. This intermittent stream begins losing flow to the underlying sand and gravel aquifer south of the waste pit area. Finally, about $2.4 \mathrm{~km}$ (1.5 miles) south of the site, Paddys Run empties into the Great Miami River. 


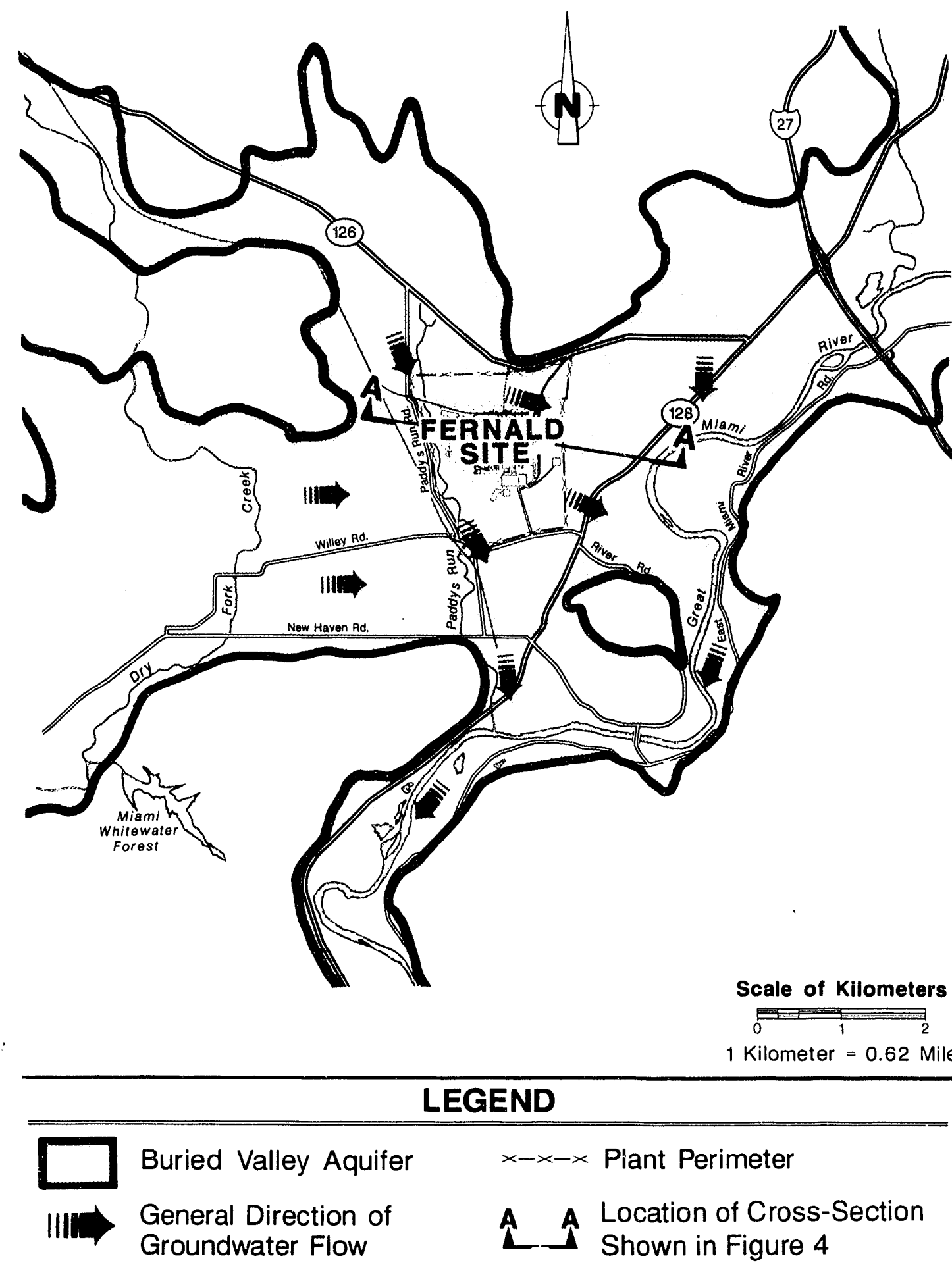




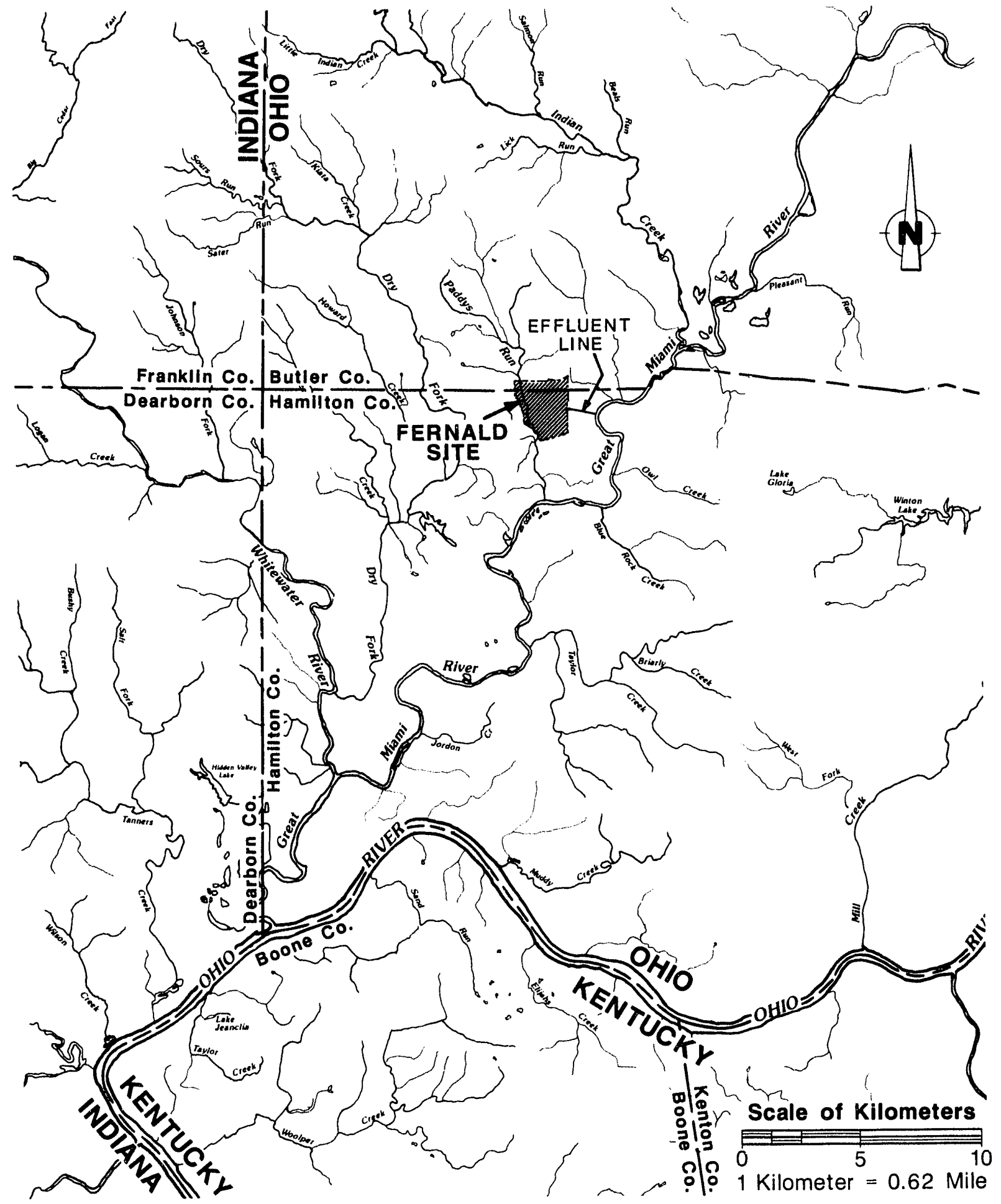


In addition to natural drainage through Paddys Run, site runoff is collected, treated, and discharged to the Great Miami River through an effluent pipeline. The river, about $1 \mathrm{~km}$ ( 0.6 miles) east and south of the Fernald site, runs in a southerly direction and flows into the Ohio River about $39 \mathrm{~km}$ ( 24 miles) downstream of the site. Although turbulence makes the Great Miami River unsafe for swimming, some people do fish there. The segment of the river between the Fernald site and the Ohio River is not a source of public drinking water.

The average river flow rate for 1992 was 79 cubic meters per second $(2,800$ cubic feet per second), measured daily about $16 \mathrm{~km}$ (10 river miles) upstream of the effluent discharge. Flow rate also fluctuates throughout the year. In 1992, the mitximum rate was $710 \mathrm{cms}(25,000 \mathrm{cfs})$ measured in July; the minimum flow was $22 \mathrm{cms}(770 \mathrm{cfs})$ measured in January. ${ }^{7}$

\section{Meteorology}

The Fernald site's meteorological monitoring system was installed in August 1986. The meteorological tower is 60 meters ( $200 \mathrm{feet}$ ) tall, with monitoring equipment at both the 10-meter (33-foot) and 60-meter (200-foot) heights. The tower instruments measure wind speed and direction, ambient air temperature, dewpoint temperature, barometric pressure, and precipitation (see Table 1 on page A-2).

The meteorological instruments are inspected and re-calibrated regularly to ensure that they are functioning properly. The system is down during these routine maintenance periods but not for a length of time that significantly affects the data obtained. While the system is down, it is possible to obtain meteorological data from the Greater Cincinnati-Northern Kentucky International Airport, located about 27 km (17 miles) south of the site.

The meteorological data gathered at the site are primarily used to evaluate climatic conditions at the site. The Environmental Monitoring Program uses atmospheric models to determine how airborne effluents mix and disperse; these models, in turn, are used to assess the impact of operations on the surrounding environment, in accordance with DOE requirements.

Airborne pollutants are subject to whatever weather conditions exist. Wind speed and direction, rainfall, and temperature play a role in predicting how pollutants are distributed in the environment. Weather data, particularly wind speed and direction, provide references for collecting environmental samples and locating monitoring stations. 
Figures 7 and 8 are annual wind roses, which illustrate the average wind speed and general direction measured at the 10-meter (33-foot) and 60-meter (200-foot) levels in 1992. The wind direction was predominantly toward the northeast, blowing from the southwest sector approximately $12 \%$ of the time at the 10-meter (33-foot) level and from the south-southwest sector approximately $11 \%$ of the time at the 60 -meter (200-foot) level. Winds were calm $4.04 \%$ of the time and $1.3 \%$ of the time from the 10-meter (33-foot) and 60-meter (200-foot) levels respectively. (October data for the 60 -meter [200-foot] level were not used in these calculations because of technical problems with the wind speed sensor.)

Trees growing near the meteorological tower have an affect on the measured wind speeds at the 10-meter (33-foot) level because they act as a wind barrier. Site meteorologists have been discussing how best to correct this problem and are considering their options based on potential environmental impact and cost effectiveness.

In 1992, the precipitation measured at the Greater Cincinnati - Northern Kentucky International Airport was $96 \mathrm{~cm}$ (38 inches), which is slightly less than the average annual precipitation of $104 \mathrm{~cm}$ (41 inches) for 1960 through 1990. Figure 9 shows 1992 total precipitation in relation to the annual precipitation amounts recorded since 1982. (Precipitation totals from the airport are used because of a computer software problem at the site meteorological tower.)

Figure 7: 1992 Wind Rose Data, 10-Meter Height

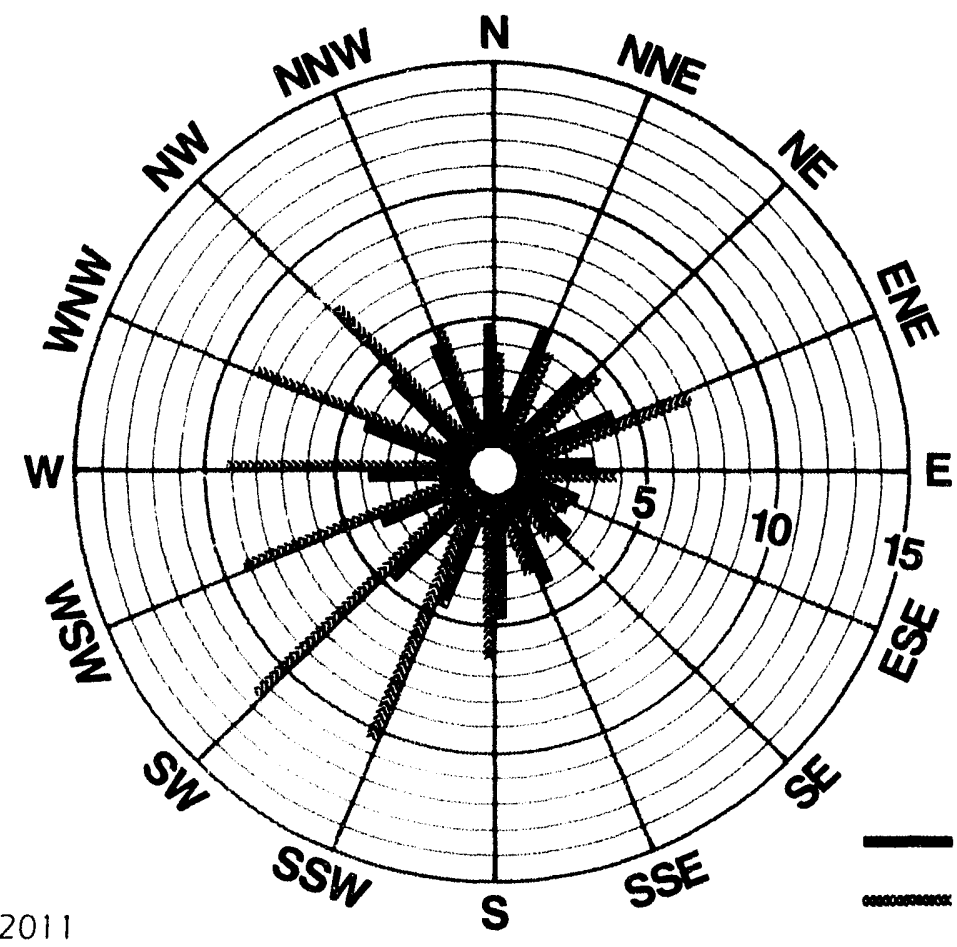

Average wind speed from this direction. Percentage of time that the wind blew from this direction. 
Figure 8: 1992 Wind Rose Data, 60-Meter Height

2011

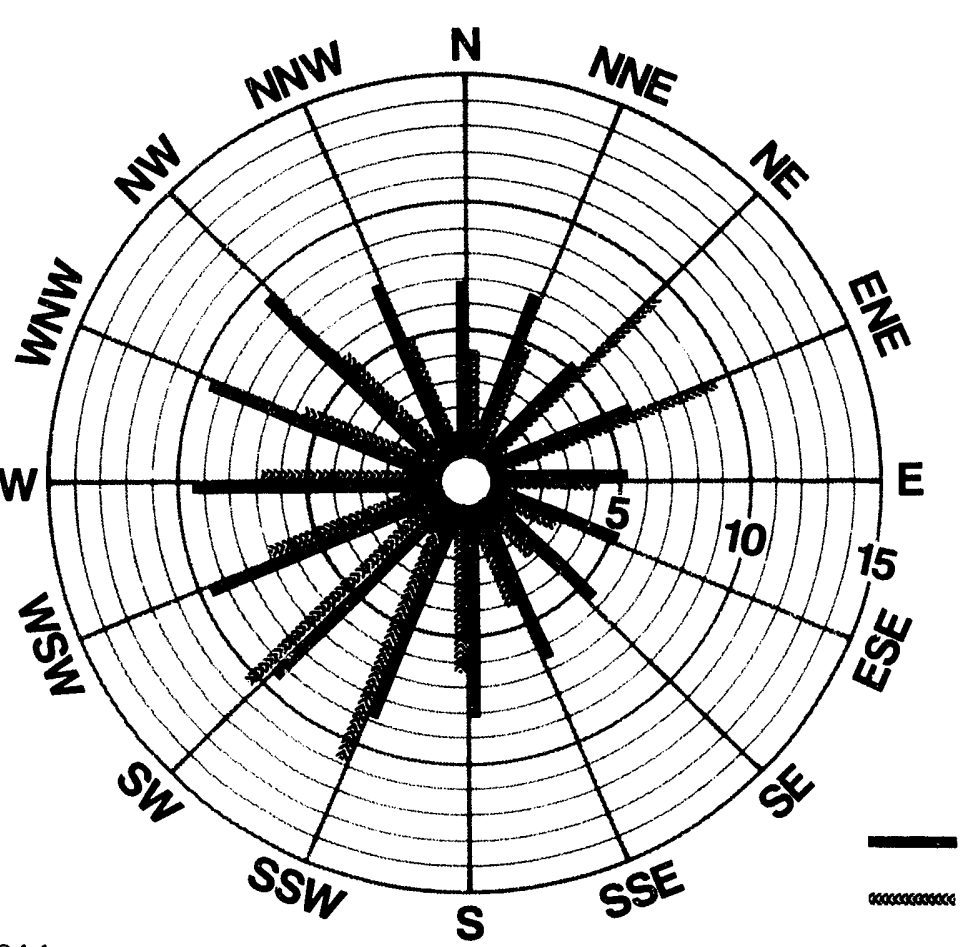

Average wind speed from this direction.

Percentage of time that the wind blew from this direction.

Figure 9: Annual Precipitation Data, 1982 - 1992

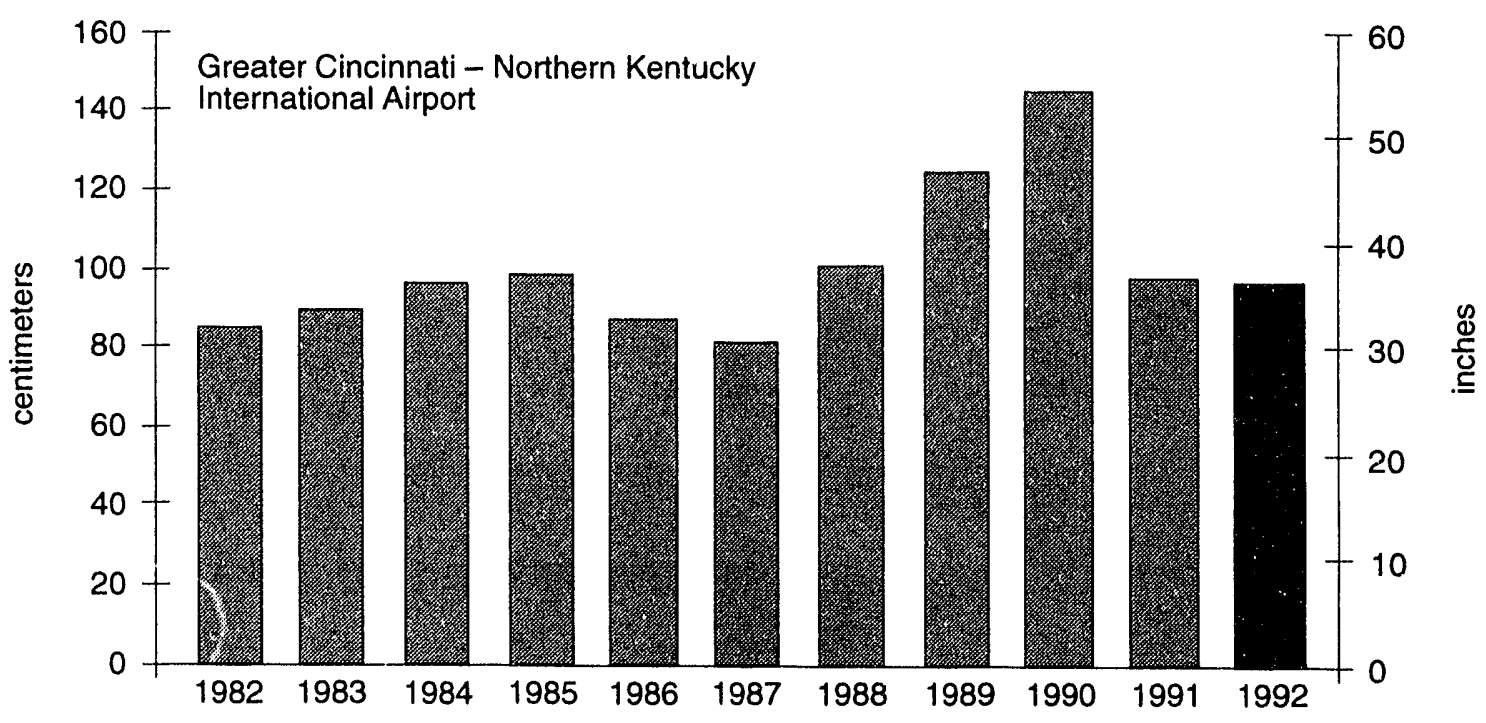




\section{Biology}

Representative of the regional climate, the area's natural vegetation is a broad-leafed deciduous forest, dominated by beech and maple hardwoods. Some of these naturally wooded areas still exist north of the site and in the Paddys Run watershed to the west. Several acres immediately north of the production area were planted with white and Austrian pines as part of a 1973 environmental improvement project. Short pasture grasses and brush cover the remainder of the site, and local dairy farmers lease Fernald site pastures for their herds to graze, consistent with the property's former agricultural uses. The plant diversity provides abundant cover for deer, eastern cottontails, woodchucks, and pheasants; bobwhite quail and assorted waterfowl have also been observed onsite. Song sparrows, blue jays, cardinals, and robins nest in the pine plantations, while Paddys Run is home to several species of small fish, including minnows, darters, and shiners.

In 1986, zoologists from Miami University in Oxford, Ohio, began a comprehensive ecological study of the site. They studied plants and animals to determine if any species were being stressed by former site operations. Based on statistical analyses, the study concluded that the site's impact on the natural habitat did not appear to be different from the ecological impact of any other local industrial site. Their report, published in 1990, also concluded that no plants or animals found onsite were on the federal endangered species list.

\section{Demography and Land Use}

Scattered residences and several villages, including Fernald, New Baltimore, Ross, New Haven, and Shandon, are located near the site (see Figure 10). Downtown Cincinnati is approximately $27 \mathrm{~km}$ (17 miles) southeast of the site, and the cities of Hamilton and Fairfield are 10 to $13 \mathrm{~km}$ (6 to 8 miles) to the northeast. There is an estimated population of over 14,600 within $8 \mathrm{~km}$ ( 5 miles) of the Fernald site, and an estimated 2.74 million within $80 \mathrm{~km}$ ( 50 miles). Table 2 on page A-3 is an estimate of population distribution in the surrounding areas.

The area's major economic activities rely heavily on the physical environment. Farming and raising dairy and beef cattle account for the majority of the land use in the area. Major crops include field corn, sweet corn, soybeans, and winter wheat. Several nearby farms also sell produce locally or in nearby urban markets.

Other important commercial products from the area include sand, gravel, and water from the aquifer. Many gravel pit operations exist along the Great Miami River valley. A water company is located $2 \mathrm{~km}$ (1.25 miles) upstream of the site's effluent discharge to the river; presently, this company pumps about $76,000 \mathrm{~m}^{3}(20$ million gallons) of groundwater per day, for sale primarily to Greater Cincinnati industries. 


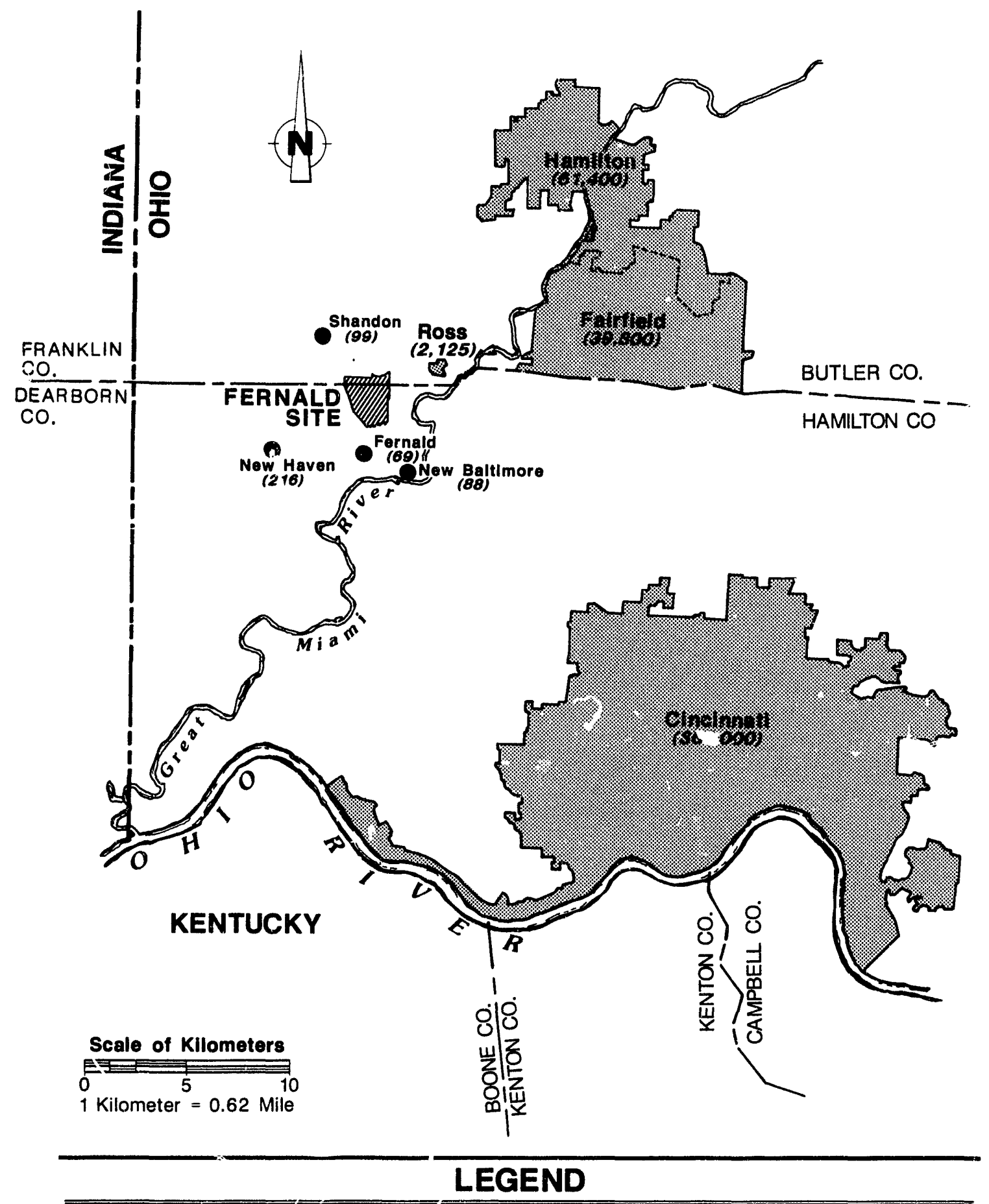

Population in parentheses estimated in 1989

Population in parentheses from 1990 U.S. Census Figures 


\section{Exposure Pathways to Humans}

To protect the local environment, the Environmental Monitoring Program focuses on exposure pathways. A pathway is a route by which materials could travel between the point of release and the point of delivering a radiation or chemical dose to a person. These pollutants may reach people directly via a primary pathway, through contaminated air or water, or through a sucondary pathway, such as the food chain. One example of a secondary pathway is the air-to-soil-to-roots-to-produce-to-human pathway. In this scenario, a gas or dust particle released from a production stack settles on a field or a plant and is absorbed into the soil. A plant may also absorb the pollutant through its roots; the chemical would then pass into the rest of the plant, including the edible portions.

This scenario presents a simplified pathway that materials may take. The actual route of the material can be very complex, and the quantity of material that could eventually reach people is very small. To develop an understanding of the complexity, take another look at the pathway and consider that not all materials released settle out of the air; some fraction may be washed out by rain and enter surface water or groundwater. Of the fraction that does settle, not all falls onto fields, and not all of that fraction on fields is absorbed by the roots of plants. This process of dilution and separation continues until some small fraction of what is released in the air may reach the leaves or fruit of the plant. Although certain plants, animals, and soils may concentrate specific materials and are therefor. important points in pathways that should be sampled, pathways frequently overlap, and it is difficult to trace them precisely. Environmental sampling and analysis are performed to detect the presence and concentration of pollutants throughout the air and liquid pathways.

Although both radioactive and nonradioactive materials can reach people through the same pathways, the pathway scenarios presented here and throughout the report will focus on radioaciive contamination since this is of primary concern at the Fernald site. Much of this report, as well as the Environmental Monitoring Program itself, focuses on radioactive contamination. Uranium is the major radioactive pollutant at the site; however, some of the uranium processed was recycled from nuclear reactors and contains trace concentrations of fission products (such as strontium-90 and cesium-137) and transuranics (such as neptunium-237, plutonium-239, and plutonium-240). These fission products are radioactive, and the site monitors for them in air and liquid discharges to the environment. These trace radionuclides also exist in the environment as a result of fallout from weapons testing and emissions from other nuclear facilities.

To organize the many pathways that exist, the Environmental Monitoring Program centers on two major pathways: air and liquid. These pathways provide a basis for the environmental sampling program and direct which environmental samples and models will be used in estimating dose. (Direct radiation, a third pathway, is monitored with radiation detection instruments that measure radiation emitted directly 
from the site, particularly from the K-65 silos. Direct radiation is discussed further in Chapter Four.) The following sections describe how materials may follow the air and liquid pathways and briefly describe environmental monitoring procedures.

\section{Air Pathway}

The air pathway includes not only all the airborne pollutants that may be carried from the Fernald site through emissions but also direct radiation (see Figure 11). Stack and building vent emissions are obvious sources of pollutants, but dust from construction and remediation activities, waste handling, and wind erosion are also important potential sources. The form and chemical makeup of pollutants influence how they are dispersed in the environment as well as how they may deliver radiation doses. For example, fine particles and gases are inhaled, while larger, heavier particles tend to settle and deposit on grass or soil. Chemical properties determine whether the pollutant will dissolve in water, be absorbed by plants and animals, or settle in sediments and soils.

For the environmental scientist, the first step in monitoring the air pathway is to measure the concentration of the pollutants at the point of release, after they have gone through treatments and filtering. This provides preliminary information on how much pollutant is released and how it will behave in the environment. It is also

\section{Figure 11: General Air Pathways to Humans}

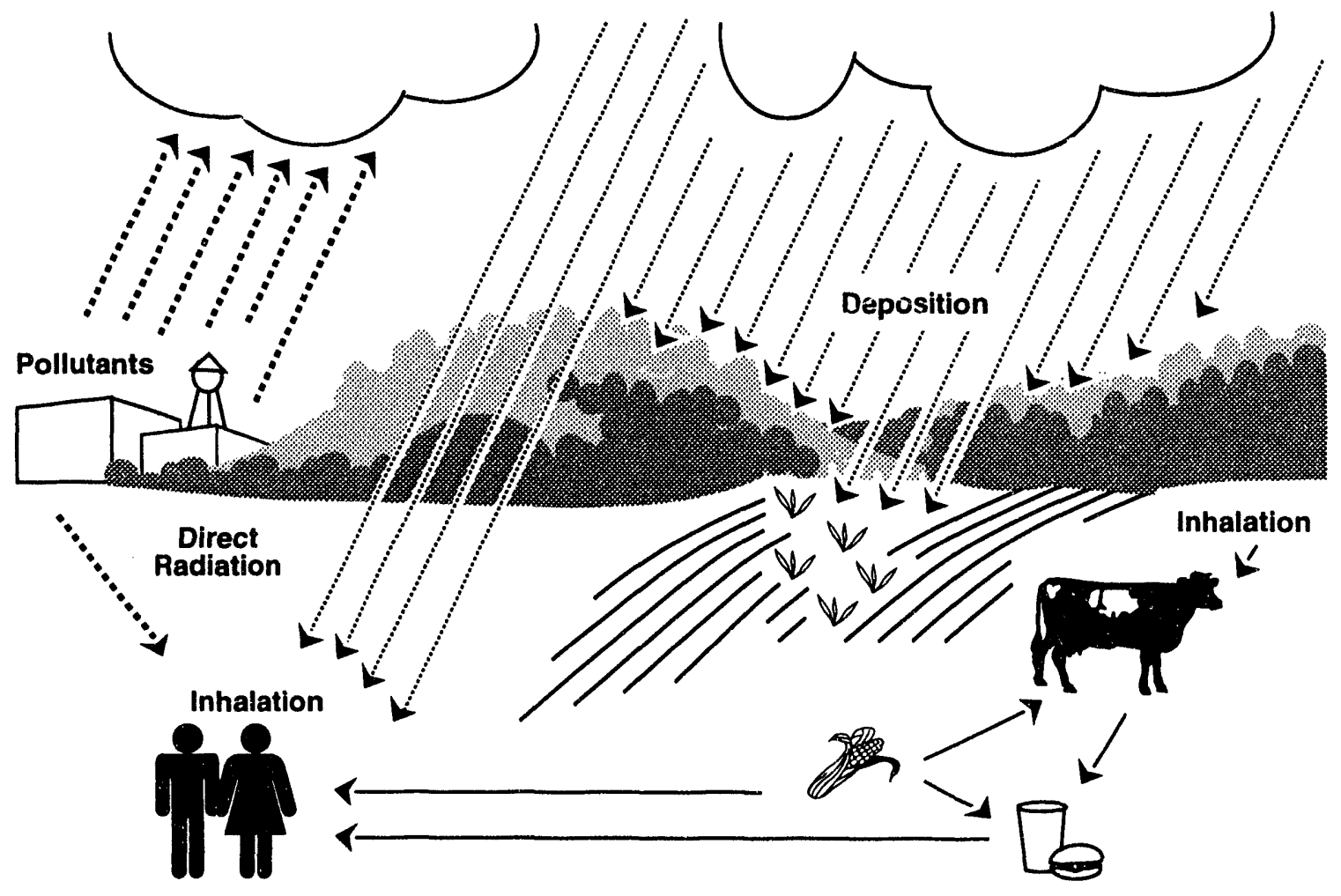


possible to estimate the concentration of contaminants in the air once the emissions pass through the stack. The site operated 16 air monitoring stations 24 hours a day, seven days a week, during 1992 to monitor these air emissions.

\section{Liquid Pathway}

The liquid pathway includes all releases that could carry waterborne pollutants (see Figure 12), such as the effluent discharge line to the Great Miami River, the overflow spillway from the Stormwater Retention Basin, uncontrolled stormwater runoff, and groundwater. Just as with the air pathway, the first step in monitoring the liquid pathway is to sample the effluent streams as they leave the site. The potential dose that could be delivered via the liquid pathway can be estimated by the type and concentration of each pollutant. Some pollutants in the liquid effluent may be carried along as suspended solids, which eventually settle out as sediment in the stream bed; other pollutants are dissolved in the water and could be absorbed by plants and animals.

Sediment sampling in Paddys Run and the Great Miami River provides information on whether pollutants are accumulating in the stream beds. Fish sampling can show whether pollutants are being absorbed by aquatic animals and how much radioactive material could reach people if they eat fish from the Great Miami River. Fish are known as biological indicators because they can concentrate certain pollutants as

Figure 12: General Liquid Pathways to Humans

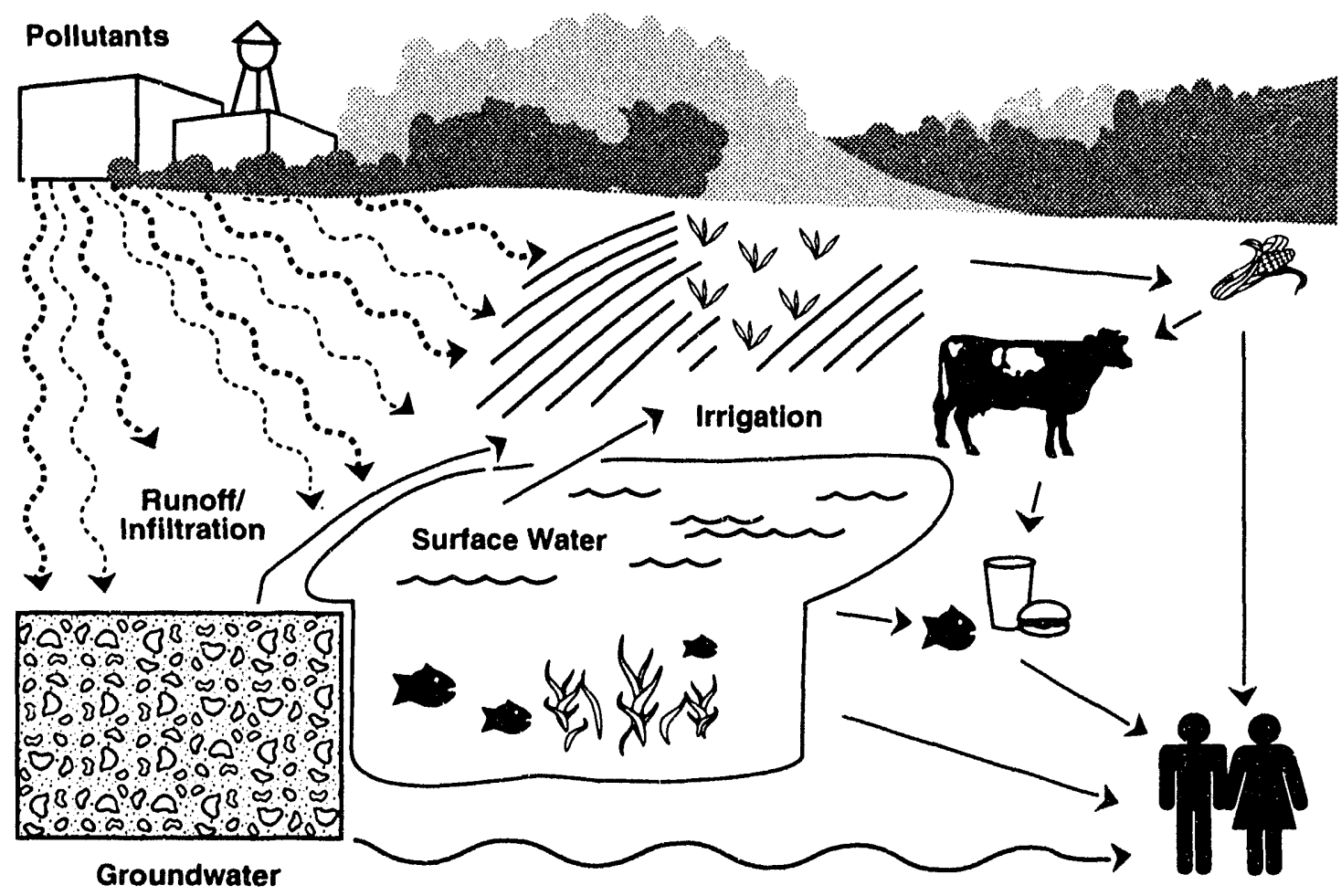


they come into contact with them. Therefore, the longer-term influence of the Fernald site can be measured through fish sampling. (Chapter Five in this report discusses these sampling activities further.)

Groundwater is an important component of the liquid pathway because it is the source of water for homes and farms in the area. Extensive sampling of the wells on the site and in the surrounding area provides information about the aquifer. By sampling the aquifer in many locations and varying depths, site personnel can determine the extent of any contamination. (Groundwater is discussed further in Chapter Six of this report.)

Each pathway has specific standards and guidelines which define the allowable dose limits for the pathway, and these are discussed in the next section.

\section{Environmental Standards and Guidelines}

As part of data analysis, site personnel compare the data to established standards and guidelines whenever possible. These standards and guidelines have been established by numerous national and international scientific and government groups, including National Council on Radiation Protection and Measurements (NCRP), International Commission on Radiological Protection (ICRP), USEPA, OEPA, and DOE.

These organizations have studied the effects of radioactive and nonradioactive materials moving through the many environmental pathways to people. From this information, standards and guidelines have been established to ensure that employees, people in the surrounding communities, and the environment are protected.

DOE adopts standards recommended by various groups of experts and publishes them in DOE orders, thereby establishing the recommendations as limits to be met by DOE facilities. For example, DOE Order 5400.5, "Radiation Protection of the Public and the Environment," defines the guidelines for radiation exposure to the public based upon recommendations of the International Commission on Radiological Protection (ICRP). ${ }^{8,9}$ Through reports and other guidance, the ICRP recommended a system of dose limits. Almost all countries with nuclear programs have adopted these recommendations, which provide a scientific basis for radiological protection and the selection of dose limits.

Once DOE publishes a standard in a DOE Order, such as 5400.5, each DOE site must meet the limits of radiation exposure established in that order. These limits refer to the amount of exposure that a person beyond a facility's boundary could receive from breathing the air or drinking the water. The standards in DOE Order 5400.5 require that routine activities not cause a member of the public to receive an effective dose from all radioactive sources (except radon and its decay products) greater than $100 \mathrm{mrem}$. This dose, known as the primary dose limit, is in addition to 
natural background radiation (discussed in Chapter Two). Underlying all rules and requirements is the philosophy of keeping exposures As Low As Reasonably Achievable (ALARA). Therefore, DOE expects doses from its operations to be just a small fraction of the 100 mrem per year limit.

In addition to the requirements of the primary dose limit and the philosophy of the ALARA process, DOE is subject to several pathway and source-specific limits defined in regulations developed by other federal agencies. These imposed dose limits include, but are not restricted to, doses from the air pathway and from the liquid pathway. For example, the Clean Air Act states that the air pathway (air emissions from a facility) cannot contribute more than a 10 mrem effective duse in one year to a member of the public. Again, doses from radon and its decay products are covered separately. ${ }^{10}$ For drinking water, DOE operations cannot contribute more than a 4 mrem effective dose in one year to a member of the public. ${ }^{11}$

DOE Order 5400.5 also establishes guidelines for concentrations of radionuclides in air emissions and in liquid effluent. These concentrations, referred to as Derived Concentration Guidelines (DCGs), are initial screening levels that enable site personnel to review emissions and effluent data and determine if there is a need for further investigation.

The Fernald site follows these standards and guidelines in its daily operations and must report monitoring results on a regular basis to DOE, USEPA, and OEPA. Examples of these reports include:

- Annual Radionuclide Air Emissions Report to DOE and USEPA,

- NPDES Monthly Discharge Monitoring Report to OEPA,

- Effluent Information System/Onsite Discharge Information System to DOE,

- Monthly Consent Agreement Report to USEPA,

- SARA 313 Report to USEPA and OEPA, and

- Quarterly Report of Radionuclide Discharges to USEPA.

This SER compares the results of the site's monitoring program to specific standards for various pollutants. Some pollutants do not yet have standards and DCGs established. Furthermore, there are instances where standards do not exist for specific media, such as uranium in soil, grass, produce, or fish. Where no standards or guidelines are available, other points of reference are presented in order to help the reader assess the impact of Fernald site operations. For example, results are compared with background data from areas unaffected by the Fernald site activities. Results from 1992 are also comparer with results from previous years to look for possible trends.

The remainder of this report discusses some basic facts about radiation and other health hazards, compliance activities, the Environmental Monitoring Program for 1992, and cleanup activities. 


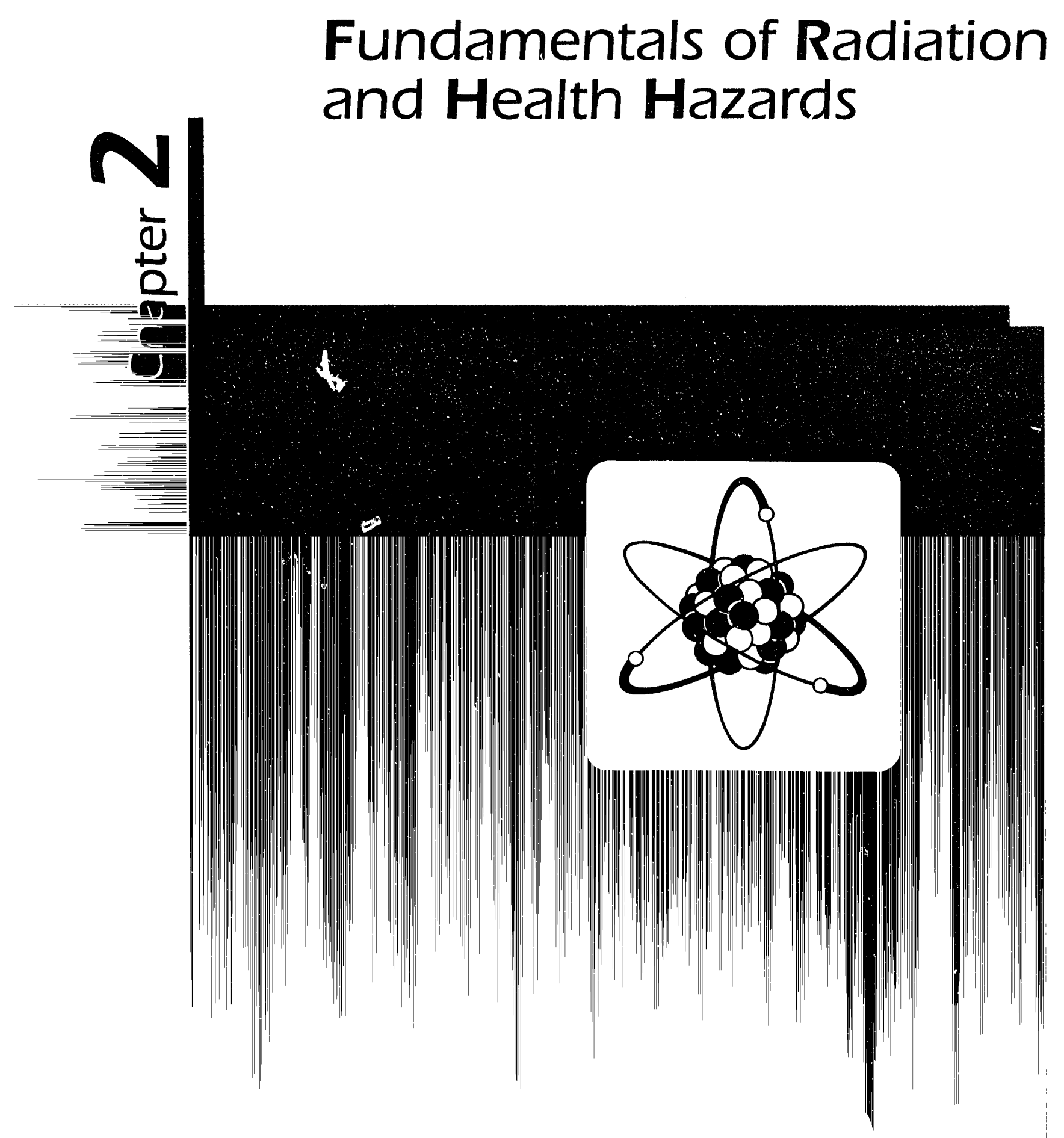




\section{Fundamentals of Radiation and Health Hazards}

Since radioactive materials and hazardous chemicals are stored at the Fernald site, it is important to understand the possible health hazards associated with these materials. Also, terms unique to radiation and its potential health effects are used extensively throughout this report. As a result, some of the important information in the report may be difficult for the non-scientist to interpret. This chapter provides a way to put that information into perspective and includes the following topics:

- The atom,

- Radioactivity and radiation,

- The units used to measure radiation,

- Background radiation,

- The effects of radiation,

- "Hazardous" definitions,

- Laws regulating health hazards, and

- Types of health threats.

Readers who are already familiar with the concepts and terms used in the study of radiation and other health hazards may wish to proceed directly to the next chapter, the Environmental Compliance Summary. 


\section{The Atom}

The world is made up of atoms. Atoms consist of two basic parts:

- The nucleus, and

- The electrons orbiting the nucleus.

The nucleus is made up of protons, which are positively charged, and neutrons, which have no charge. Protons and neutrons are similar in size, and both are considerably larger than electrons (about 1,800 times more massive). Therefore, the weight and mass of the atom is principally concentrated in the nucleus. The electrons circling the nucleus have a negative charge. Atoms tend to move toward a neutral state in which the negative electrical charge of the orbiting electrons balances the positive charge of the nucleus. To keep the atom electrically neutral, the number of

Figure 13: Structure of the Atom

The Nucleus of an Atom The nucleus has many protons (white) and neutrons (red). Notice that there are never two protons touching each other. Similar to a magnet the positively charged protons repel each other. There must be neutrons separating the protons.
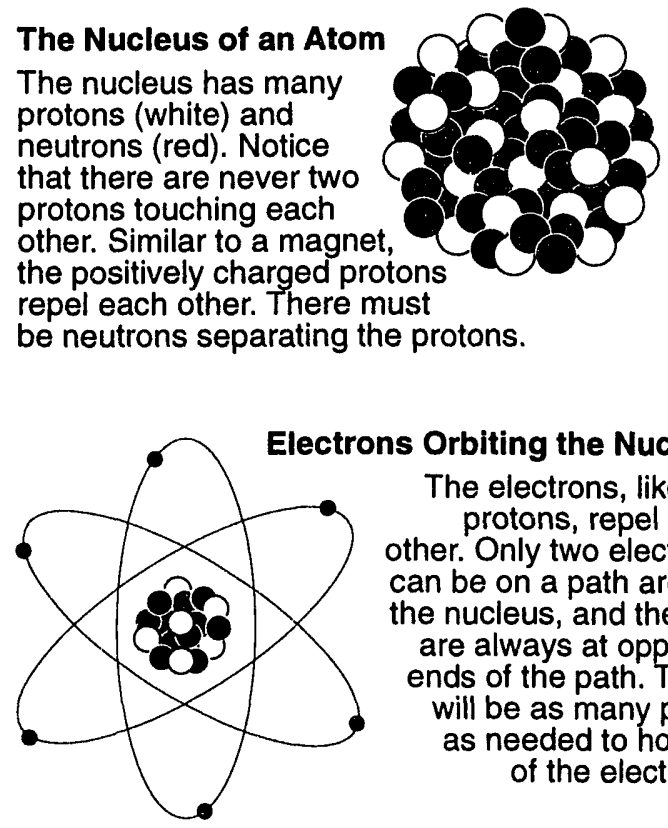

The Hydrogen Nucleus

The hydrogen nucleus always has one proton and can have zero, one or two neutrons. The protons are positive and the neutrons are neutral.

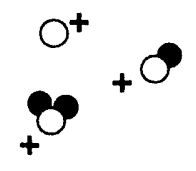
electrons in an atom must equal the number of protons (see Figure 13).

Protons and electrons have many characteristics similar to magnets. Just as opposite magnetic poles are drawn toward each other, protons and electrons are attracted toward each other. This attraction keeps the electrons orbiting around the nucleus. The electrons are not pulled into the nucleus because of the electrons' energy. This energy keeps them constantly moving and away from the protons. The energy in the electrons and the attraction of the electrons to the protons balance each other and keep the electrons in orbit. Just as energy in the electrons keeps them orbiting, energy in the nucleus keeps the protons and neutrons together.

The number of protons in the nucleus is referred to as the atomic number, and it is the identifier of the atom. If the atomic number changes, then the number of electrons and the chemical properties of the atom change. For example, for an atom to be hydrogen, it must have one proton. If a hydrogen atom were to gain a proton, it would no longer be hydrogen; it would be helium, which has two protons. Uranium, the substance of most concern at this site, has 92 protons. Since protons are positively charged, the atom must also have 92 electrons for it to be electrically neutral. 
The sum of the protons and neutrons in the nucleus is called the mass number. Unlike protons, the number of neutrons contained in a specific atom can vary since neutrons have no charge and do not need to be balanced by electrons. Therefore, the mass number can vary. For example, a hydrogen atom always has one proton, but it can have either zero, one, or two neutrons. The different hydrogen atoms are called isotopes of hydrogen. Isotopes are labelled with their mass number. A hydrogen atom without a neutron is referred to as hydrogen-1 where 1 is the mass number. The hydrogen isotope with one neutron is referred to as hydrogen-2, and the isotope with two neutrons is referred to as hydrogen-3.

Most of the uranium at the Fernald site contains 146 neutrons to go with the 92 protons present in every uranium nucleus; therefore, the mass number is 238 (146 neutrons +92 protons $=238$ ). Uranium -234 has 142 neutrons +92 protons, uranium-235 has 143 neutrons +92 protons, and uranium-236 has 144 neutrons +92 protons. All isotopes of uranium are radioactive. Radioactivity and radiation are described in the next section.

\section{Radioactivity and Radiation}

Radioactivity is a process in which a nucleus of an unstable atom spontaneously decays or disintegrates. Radiation is the energy that is released as particles or waves when the disintegration or decay of the nucleus occurs. This section includes a discussion of radioactive decay and the three main forms of radiation produced by radioactivity:

- Alpha particles,

- Beta particles, and

- Gamma rays.

It should be noted, however, that not all radioactive substances emit all three types of radiation. Some homeowners have expressed concern about receiving radiation from gamma rays due to the presence of uranium-238 in well water. However, uranium238 emits alpha particles, not gamma rays. The differences between alpha particles and gamma rays will be clarified in the discussions that follow.

\section{Radioactive Decay}

Atoms are radioactive because their nucleus is too large (because of the number of protons and neutrons) or has too much energy to remain stable. By emitting radiation, the nucleus releases energy and moves toward a more stable, less energetic state and eventualiy becomes a stable atom. Radioactive decay occurs everywhere on earth because of naturally occurring radioactive elements. When most radioactive elements decay, the resulting atom is also radioactive. This is called a radioactive decay chain. There are four natural radioactive decay chains. A common chain begins with uranium-238 and ends with lead-206 (this isotope of lead is stable, 
which means it does not decay). Each of the various radioactive atoms (radionuclides) created during the decay sequence has its own natural rate of decay.

It takes a different amount of time for each element to decay to the next element in the chain. The amount of time it takes for a radioactive substance to lose half of its radioactivity, or for half to become the next element in the chain, is its half-life. All

\section{ADdREsSing HOMEOWNER CONCERNS ABOUT USES OF W/EL WATER}

Several homeowners near the Fernald site have expressed concern as to why well water with low concentrations of natural uranium may be acceptable for household utility uses such as washing clothes, bathing, and watering plants, but may not be acceptable for drinking or cooking. To some, this has seemed an inconsistency and cause for misunderstanding.

The key to understanding why the water is acceptable for external uses is an understanding of how alpha particles, of prime concern when dealing with uranium, deliver a radiation dose. Alpha particles are large, charged particles that readily interact with other materials. This interaction prevents the particles from ever penetrating very deeply. Even the most energetic alphas from uranium are stopped by the outer layers of dead skin.

However, inside the body, there are no protective dead cell layers to prevent the alpha particles from interacting with live organ cells; all emitted energy is delivered as dose to the organ. The alpha-emitting radionuclide may also be incorporated into the cell structure as if it were a different chemical. For example, the body processes several radionuclides as though they were calcium; predictably, they end up being deposited in the bones. Research has shown that uranium tends to concentrate in the bone and, to a lesser extent, in the liver, kidneys, and other tissues.

There is also a chemical toxicity associated with uranium, in dependent of its associated radiation hazards. Studies indicate that uranium is toxic to the kidney cells at concentrations equivalent to $60,000 \mathrm{pCi} / \mathrm{L}$.

Although the concentrations of concern in these studies are several thousand times greater than the concentration of uranium in local groundwater, it is desirable to limit the intake of uranium. While no measurable increase in health effects can be expected by drinking water with slightly higher than typical background concentrations of uranium, decreasing the amount of uranium ingested may provide valuable peace of mind to those concerned. And, even with slightly higher uranium concentrations, the water is still acceptable for external, household utility use. decay chains found in nature begin with an isotope with an extremely long half-life. It is assumed that these atoms were formed at the same time as all the other atoms on earth and are still present because their half-lives are comparable to the age of the earth.

The uranium decay sequence is a common example in nature and here at the Fernald site. (The uranium and thorium decay chains are presented on the following page.) Uranium-238 emits an alpha particle (two protons and two neutrons) and becomes thorium234. Then a neutron in thorium-234 becomes a proton and an electron. The electron is emitted as a beta particle. Then thorium-234 decays to protactinium-234. The decay process proceeds in this manner until the element becomes stable as lead-206. Much of the uranium and thorium at the Fernald site has been chemically purified and separated from other elements shown in the decay series. Elements separated from uranium and thorium are some of the wastes stored onsite. The material stored in the K-65 silos is an example of such waste. 


\begin{tabular}{|c|c|c|c|}
\hline \multirow{3}{*}{$\begin{array}{l}\text { Nuclides } \\
\text { of the Uranium } \\
\text { Decay Chain }\end{array}$} & Isotope & Half-life & Radiation \\
\hline & Uranium-238 & $4,500,000,000$ years & alpha \\
\hline & Thorium-234 & 24 days & beta, gamma \\
\hline & Protactinium-234m & 1.2 minutes & beta, gamma \\
\hline & Uranium-234 & 250,000 years & alpha, gamma \\
\hline & Thorium-230 & 80,000 years & alpha, gamma \\
\hline & Radium-226 & 1,622 years & alpha, gamma \\
\hline & Radon-222 & 3.8 days & alpha \\
\hline & Polonium-218 & 3.05 minutes & alpha \\
\hline & Lead-214 & 26.8 minutes & beta, gamma \\
\hline & Astatine-218 & 2.0 seconds & alpha \\
\hline & Bismuth--214 & 19.7 minutes & beta, gamma \\
\hline & Polonium-214 & 0.000164 second & alpha, gamma \\
\hline & Thallium-210 & 1.3 minutes & beta, gamma \\
\hline & Lead-210 & 22 years & beta, gamma \\
\hline & Bismuth-210 & 5.0 days & beta \\
\hline & Polonium-210 & 138 days & alpha, gamma \\
\hline & Thallium-206 & 4.2 minutes & beta \\
\hline & Lead-206 & Stable & none \\
\hline \multirow{13}{*}{$\begin{array}{l}\text { Nuclides } \\
\text { of the Thorium } \\
\text { Decay Chain }\end{array}$} & Isotope & Half-life & Radiation \\
\hline & Thorium-232 & $14,000,000,000$ years & alpha \\
\hline & Radium-228 & 6.7 years & beta \\
\hline & Actinium-228 & 6.13 hours & beta, gamma \\
\hline & Thorium-228 & 1.9 years & alpha, gamma \\
\hline & Radium-224 & 3.64 days & alpha, gamma \\
\hline & Radon-220 & 55 seconds & alpha \\
\hline & Polonium-216 & 0.16 second & alpha \\
\hline & Lead-212 & 10.6 hours & beta, gamma \\
\hline & Bismuth-212 & 60.5 minutes & alpha, beta, gamma \\
\hline & Polonium-212 & 0.000000304 second & alpha \\
\hline & Thallium-208 & 3.1 minutes & beta, gamma \\
\hline & Lead-208 & Stable & none \\
\hline
\end{tabular}

Example To illustrate the idea of half life, let's look at the isotope thorium -234 . Its halfife is 24 days. If you started with 1,000 atoms of thorium -234 after 24 days you would have 500 . Ater another 24 days you would have 250 , and so on. The halfiffe of some isotepes such as uranium-238, is very long. The middle column in the uranium and thorium decay chain examples contains the half-life periods of the elements in the decay chain. All the radionuclides in the Uranium Chain can be thought of as "potential" lead-206 atoms. This will be the case many billions of years into the future when all natural radioactive isotopes will have decayed to their stable end products. 


\section{Apha Particles}

Alpha particles consist of two protons and two neutrons and have a positive charge. Because they are charged, they interact with other atoms by scattering off other charged particles, thus losing their energy. Moreover, because of their large size, alpha particles do not travel very far when emitted ( 1 to 8 centimeters in air). They are unable to penetrate any solid material, such as paper or skin, to any significant depth (see Figure 14). However, if alpha particles are released inside the body, they can damage the soft internal tissues because they deposit all their energy in a very

\section{Figure 14: Types of Ionizing Radiation}

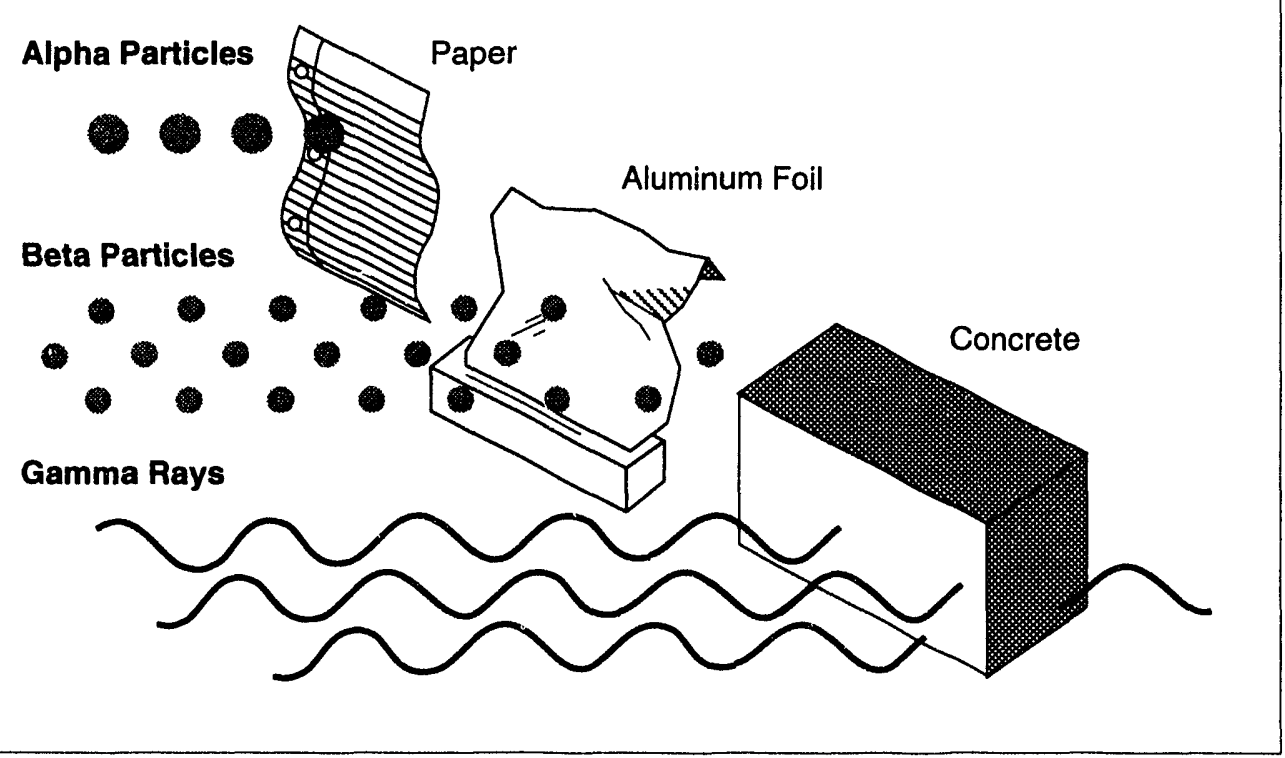

small volume. Ura-

nium decays by emitting alpha particles, so if uranium particles are inhaled or swallowed, the emitted alpha particles may damage internal tissue. Some other radionuclides present at the Fernald site that decay by emitting alpha particles include thorium-228, -230 , and -232 .

\section{Beta Particles}

Beta particles are electrons that carry a negative electrical charge. They are much smaller than alpha particles and travel at nearly the speed of light; thus, they can travel approximately 2 to 4 meters ( 6 to 12 feet) in air and penetrate solid materials about $1 \mathrm{~cm}(0.4 \mathrm{inch})$. Beta particles interact with other atoms in ways similar to alpha particles, but since they are smaller, faster, and have less charge, they cause less concentrated damage when interacting with tissue. Thorium-234, a decay product of uranium-238, emits beta particles.

\section{Gamma Rays}

Gamma rays are bundles of electromagnetic energy which behave as though they were particles. These pseudo-particles are called photons. They are similar to visible light, but of a much higher energy. For example, X-rays are a type of high-energy electromagnetic radiation, and excessive exposure to $\mathrm{X}$-rays can damage the body. Gamma rays are generally more energetic than X-rays. They can travel long distances and can penetrate not only skin, but, depending on their energy, can penetrate 
substantial distances into solid materials such as concrete or steel. Gamma rays are often released during radioactive decay along with alpha and beta particles. Some of the materials stored in the K-65 silos decay by emitting gamma rays. Potassium- 40 is an example of a naturally occurring radionuclide found in all human tissue that decays by emitting a relatively high-energy gamma ray. The typical human body contains about 110,000 picocuries of potassium-40. (Units of radiation are discussed below.)

\section{Interaction with Matter}

When radiation interacts with other materials, it affects the atoms of those materials principally by knocking the negatively charged electrons out of orbit. This causes the atom to lose its electrical neutrality and become positively charged. An atom that is charged, either positively or negatively, is called an ion. Anything that creates an ion is said to be ionizing.

\section{Units of Measurement}

To measure the effect of radiation, scientists have developed ways to measure levels and intensity of radiation. Some of these measurement units are technical and may require some explanation. Additional terms are included in the glossary of this report.

\section{Activity}

Activity is the number of nuclei in a material that decays per unit of time. An amount of radioactive material that decays at a rate of 37 billion atoms per second has an activity of one Curie (Ci). Smaller sub-units of the Curie are often used in

\section{Figure 15: Comparison of Disintegration Rate*}

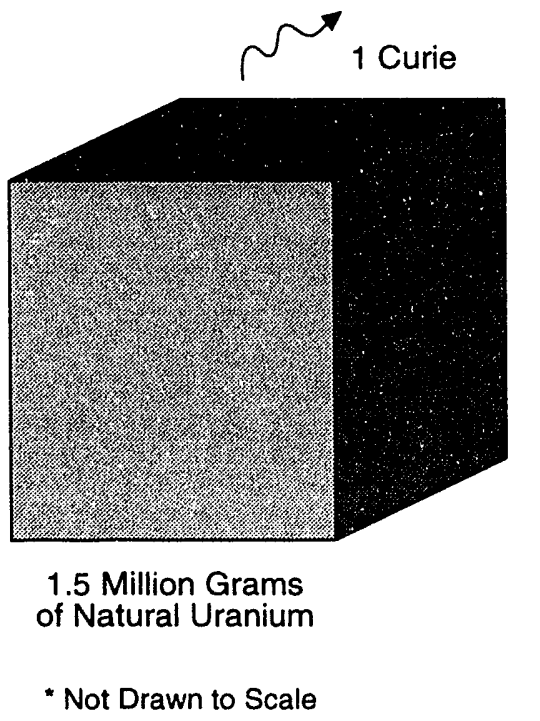

this report. Two common units are the microcurie $(\mu \mathrm{Ci})$, one millionth of a Curie, and the picocurie $(\mathrm{pCi})$, one trillionth of a Curie. The amount of radioactive material required to emit one Curie depends on the disintegration rate. For example, about one gram of radium-226, with a half-life of 1,622 years, is one Curie of activity. On the other hand, it would require about 1.5 million grams of natural uranium, which has a half-life of 4.5 billion years, to equal one Curie because natural uranium is less radioactive than radium-226. Radon-222, with a haif-life of only 3.8 days, is even more radioactive than radium-226, and only 0.0000065 gram of radon-222 is needed to equal one Curie (see Figure 15). 


\section{Dose Equivalent}

When a person comes into contact with radiation, that person has been exposed to radiation. Dose equivalent is a measure of the amount of radiation that is delivered to the body. Alpha, beta, and gamma radiation affect the body to different degrees. To take these different effects into account, each type of radiation is assigned a quality factor $(\mathrm{QF})$. The more damaging the type of radiation, the higher the $\mathrm{QF}$. For Lita and gamma ıcidiation, the $\mathrm{QF}$ is one. For alpha radiation, the $\mathrm{QF}$ is 20 . The $\mathrm{QF}$ number is multiplied by an absorbed dose to calculate an exposed person's dose equivalent. Dose equivalent, or simply dose, is used when comparing the effects of different types of radiation. The rem unit is used to express dose equivalent. The more rem, the higher the potential damage. Since the amount of radiation we receive from backyivin $\mathrm{l}$ and the Fernald site is so small, millirem (mrem) is often used instead of rem. One mrem is equal to $1 / 1000$ of a rem.

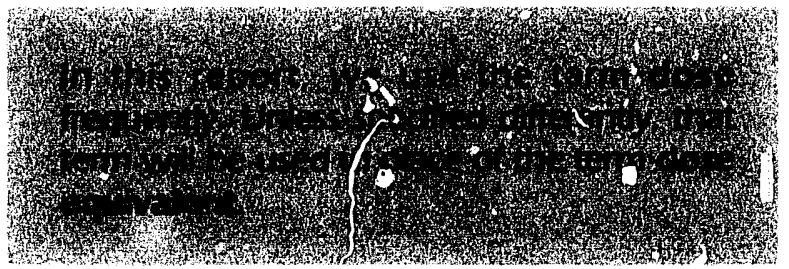

The term dose is used in four different ways in this report: organ dose, effective dose, committed effective dose, and whole body dose.

The organ dose is the amount of radiation received by an individual organ in the body. The amount of radiation any organ will absorb depends upon a variety of factors (for example, the way the radiation entered the body and the type of radiation). Therefore, when discussing the organ dose, scientists often refer only to the organ of greatest importance called the critical organ. The critical organ varies from situation to situation. It is determined based on things such as the amount of radiation received, the chemistry of the radionuclide, the sensitivity of that organ to the particular form of radiation, and the importance of that organ to the body. Based on the radionuclides found onsite, scientists have identified the critical organs as the lung, kidney, and bone surface (endosteum). rigure 16 shows which organs are most affected by various substances found at the site.

The effective dose expresses how much of a health risk radiation doses pose to individuals. To determine the effective dose, scientists first estimate each organ dose. Then, since some organs are more sensitive to radiation than others, the organs are given different weighting factors, similar to quality factors. The greater the risk an organ has of developing cancer and the more important that organ is to human health, the higher the weighting factor. The weighting factor is multiplied by the organ dose for each organ. These numbers are then added together to give the effective dose.

The NCRP and ICRP recommend that an individual be exposed to no more than 100 mrem effective dose per year for all pathways (over and above the amount a person receives from background and medical radiation). This recommendation applies to the general public for long-term, continuous exposure :.$^{12}$ The DOE guideline for 
Figure 16: Organs Affected by Substances Found at the Fernald Site

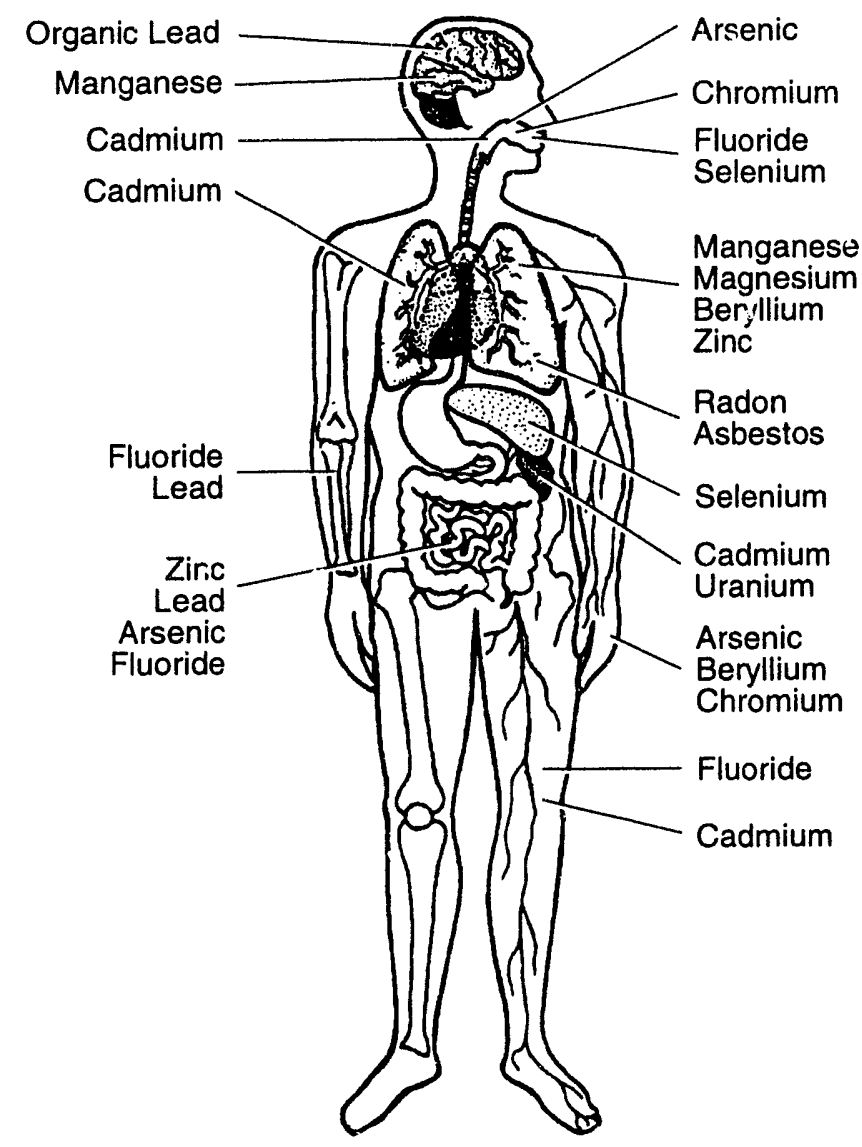

dose to members of the public is 100 mrem per year from all pathways (excluding radon). The National Emission Standards for Hazardous Air Pollutants (NESHAP) limit for effective dose is 10 mrem per year from radionuclides (except radon) released via the air pathway. ${ }^{10}$

The committed effective dose is the total amount of radiation an individual receives over a specified period of time from radioactive materials inside the body. When a person breathes or eats something that contains radivactive materials, the radiation within those materials is not all released at once. Half of the radiation is released over a period of time equal to the half-life of the radioactive material. Meanwhile, the body excretes radioactive materials at various rates determined by the individual's metabolism and the biochemistry of the radioactive material. Scientists have developed the concept of the committed effective dose to estimate the total amount of radiation one will receive over time (generally a 50 -year period) from the radioactive materials taken into the body in a given time period.

The whole body dose is the amount of radiation an individual receives when the entire body is irradiated evenly by direct (gamma) radiation. Most radionuclides present at the Fernald site do not contribute toward a whole body dose because they concentrate more in some organs than others and do not emit significant amounts of gamma radiation.

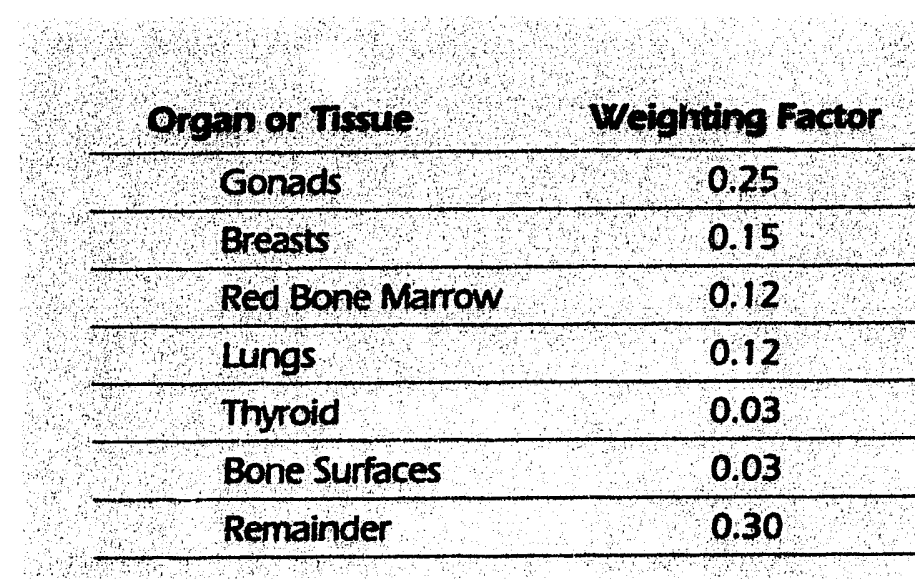

"Remainder" means the five other organs with the highest dose (e.g., liver, kidney, spleen, thymus, adrenal, pancreas, stomach, small intestine, or upper and lower large intestine, but excluding skin, lens of the eye, and extremities). The weighting factor for each of these organs is 0.06 . 


\section{Exposure to Background Radiation}

The dose terms defined in the preceding paragraphs apply to more than just the radiation we may be exposed to from facilities like the Fernald site. All people are constantly exposed to other background and man-made sources of radiation. Such radiation includes the decay of radioactive elements in the earth's crust, a steady stream of high-energy particles from space called cosmic radiation, naturally occurring radioactive isotopes in the human body like potassium-40, medical procedures, man-made phosphate fertilizers (phosphates and uranium are often found together in nature), and even household items like televisions. ${ }^{13}$ In the United States, a person's average annual exposure to background radiation is $360 \mathrm{mrem} .{ }^{12}$ The DOE guidelines (as well as other radiological guidelines) apply to exposures individuals receive in addition to background radiation and medical procedures.

As the Exposure to Background Radiation Chart shows, radon is the largest contributor to background radiation (see Figure 17). At an average of 200 mrem per year, naturally occurring radon accounts for more than half of the background dose in the United States. ${ }^{9}$ (Radon is discussed further in Chapter Eight.)

Background radiation dose will vary in different parts of the country. For example, living in the Cincinnati area will produce an exposure level of approximately 110 mrem, while the dose received annually from living in Denver is approximately 125 mrem. This difference can be attributed to soil composition and distance above sea

Figure 17: Exposure to Background Radiation

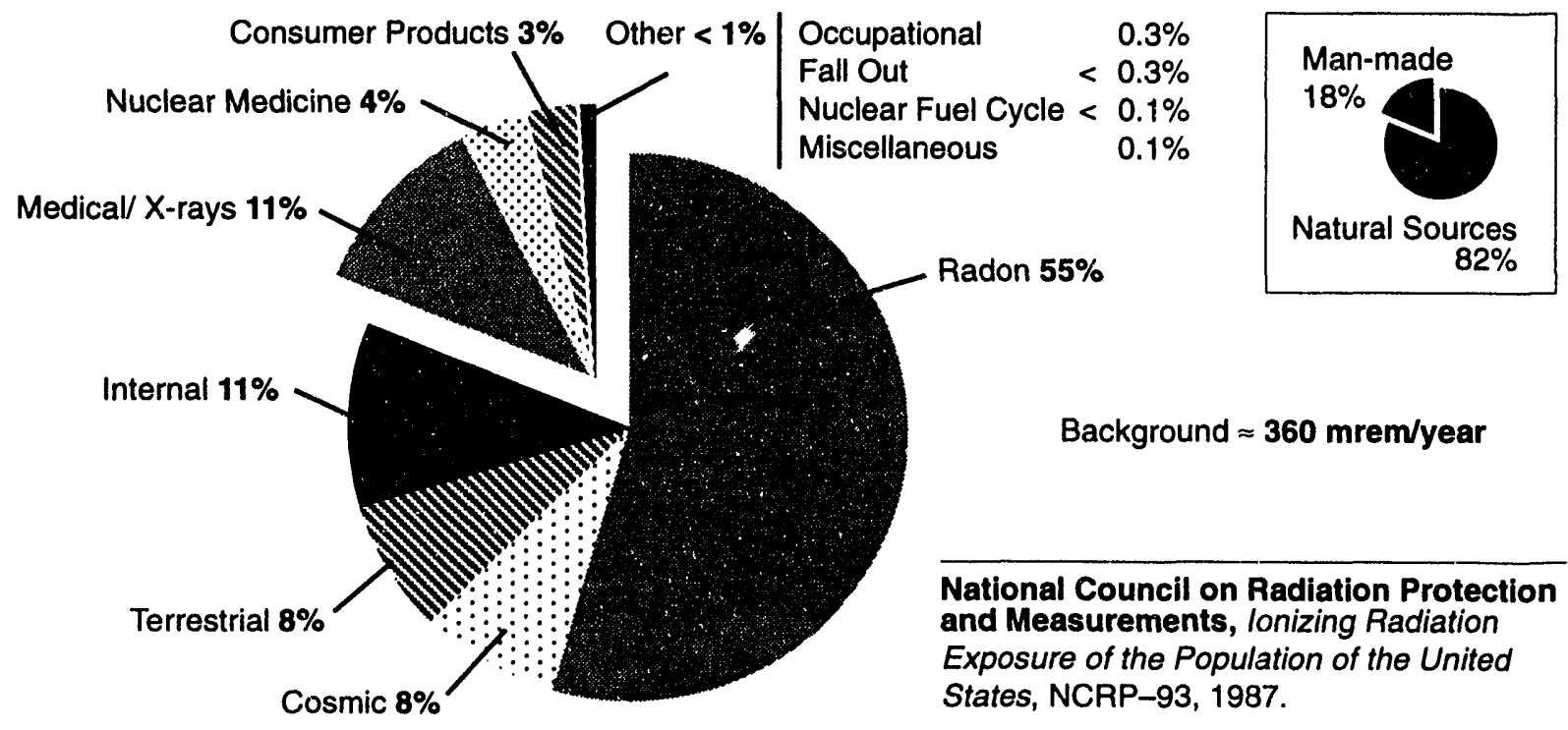


Figure 18: Breakdown of Average U.S. Radiation Exposures

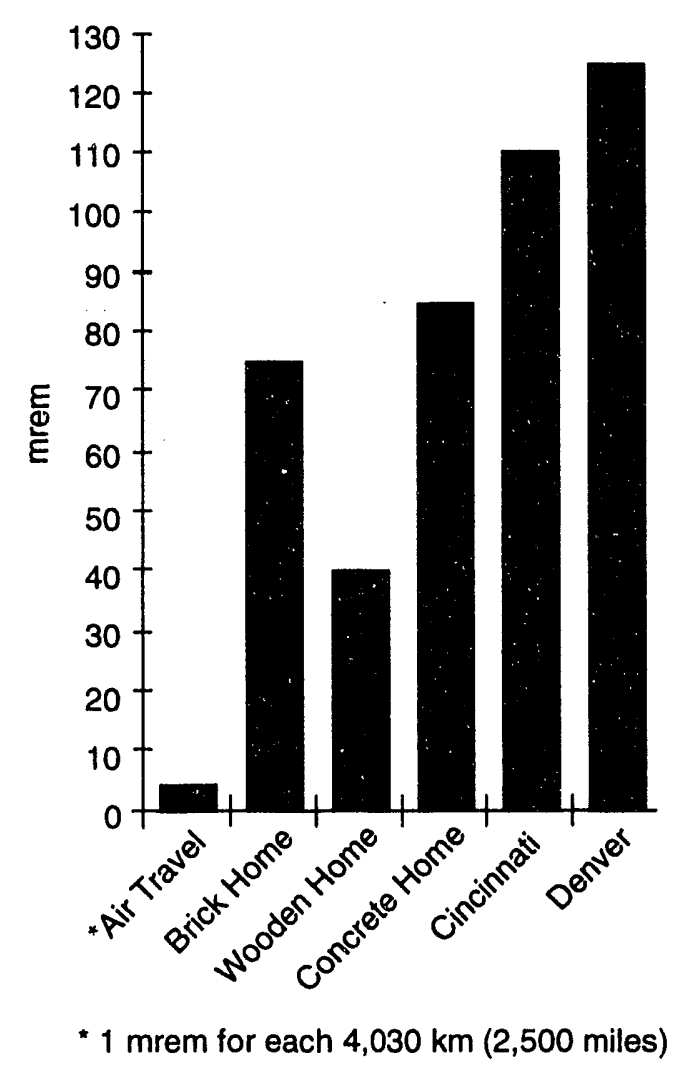

level. Another factor which affects annual radiation dose is the type of building material used in homes. Figure 18 shows that the annual dose received from living in a brick or concrete house is about two times greater than from living in a wood frame house. Also shown in the bar chart is that a single round trip flight from Cincinnati to London (or the equivalent) produces an exposure of approximately 4 mrem. ${ }^{14}$ In comparison, the dose received at the site's fenceline from an entire year is less than 0.9 mrem.

One way to measure how much radiation we are exposed to is to complete a personal radiation dose worksheet, like the one on the next page. The next section provides information on the effects of low-level radiation, whether it is naturally occurring or originates from a facility like the Fernald site.

\section{Effects of Radiation}

The effects of radiation on humans are divided into two categories, somatic and genetic. Somatic effects are those that develop in the directly exposed individual, including a developing fetus. Genetic effects are those that are observed in the offspring of the exposed person.

Because we are constantly exposed to both natural and man-made sources of radiation, and because the body has the capacity to repair damage from low levels of radiation, it is extremely difficult to determine the effects from low-level radiation. This section explains why this is true and how somatic and genetic effects may occur. 
Personal Background Radiation Dose Worksheet*

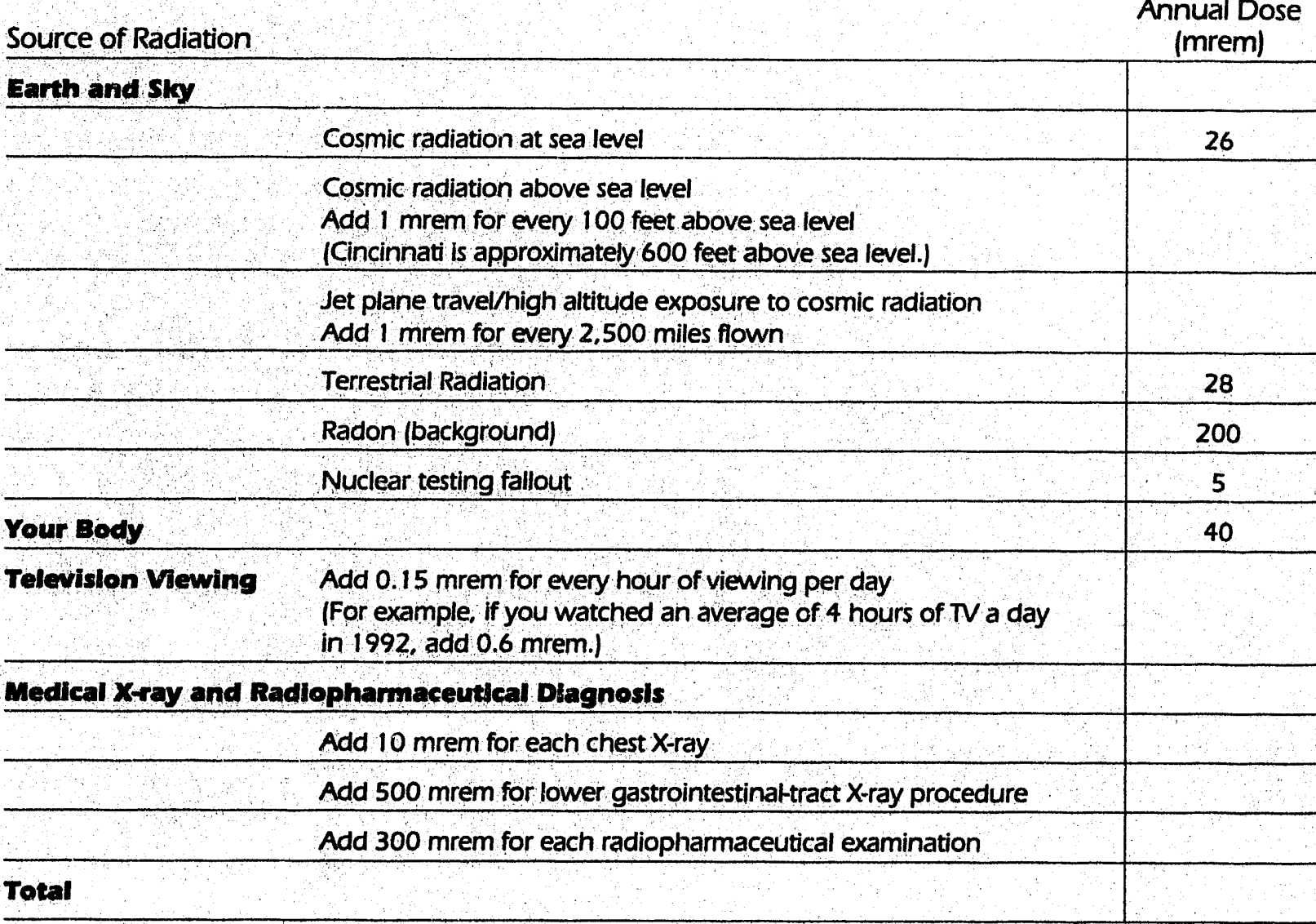

* The information is drawn from two major sources:

- BEIR Report-III-National Academy of Sciences, Committee on Blological Effects of lonizing Radiations,

"The Effects on Populations of Exposure to Low Levels of lonizing Radiation," National Academy

of Sciences, Washington, DC, 1980, and

- National Council on Radiation Protection and Measurements Report No. 93, 1987.

\section{Somatic Effects}

Continuous exposure to low levels of radiation can produce gradual somatic changes over extended time. For example, someone may develop cancer from man-made radiation, background radiation, or some other source not related to radiation. Because all illnesses caused by low-level radiation can also be caused by other factors, it is presently impossible to determine individual health effects of low-level radiation. However, there are a few groups of people under medical observation because they have been exposed to higher levels of radiation. These include the survivors of Hiroshima and Nagasaki, uranium miners in the United States and eastern Europe, a group of workers who used paint containing radium, early users of $\mathrm{X}$-ray machines, some DOE employees working in the defense facilities, and people suffering from illnesses where radioactive material was used for treatment. 
Even after studying the health effects of radiation on these groups of people, scientists are still not able to deternine with certainty how much cancer, if any, may have been caused by low-level radiation.

Those individuals exposed to high levels of radiation are at greater risk. We know this because at these higher radiation doses, we see that the number of radiation effects increases as the level of radiation dose increases.

A whole-body dose of 1,000 rem of radiation delivered instantaneously will probably kill a person. A dose of 600 to 1,000 rem causes severe sickness, but there is some chance for recovery. A dose of 200 to 600 rem causes some sickness with a very good chance for recovery. A dose of 100 to 200 rem could possibly cause some vomiting, but probably no demonstrable long-lasting effects. ${ }^{15}$

Significant clinical symptoms of radiation probably will not be seen in individuals who have been exposed to less than 100 rem. ${ }^{16}$ (The dose to the maximally exposed individual from all pathways, except radon, was less than 0.9 mrem in 1992.) Most scientists believe that there are no directly observable short-term radiation effects on human beings exposed to less than 10 rem because the biological damage created by this level of radiation is too small to result in near-term clinical symptoms.

Estimates on the value of the threshold level for radiation effects, if such a level exists, vary significantly. As mentioned above, some scientists believe it could be as high as 10 rem. ${ }^{15}$ Others insist there is no threshold level below which radiation exposure is safe. ${ }^{17}$ They feel there is always a direct relation between the amount of radiation to which people are exposed and the number of related radiation effects.

Somatic effects have been documented only at high radiation levels. These include clouding of the lens of the eye, lowered fertility rate, and a reduced number of white cells in the blood. Problems caused by radiation seen in the development of the embryo result from large doses, not the low levels characteristic of background radiation. Therefore, the most likely somatic effect of low-level radiation is believed to be a small increased risk of cancer. ${ }^{13}$

\section{Genetic Effects}

A single ionizing event has the potential to cause a genetic effect. To understand why this is true, it is helpful to look at the structure of a human cell.

Human cells normally contain 46 chromosomes- 23 transmitted from the mother and 23 from the father. These 46 chromosomes contain about 10,000 genes which are passed on to the next generation and determine many physical and psychological characteristics of the individual.

Radiation can cause physical changes or mutations in these genes. Chromosome fibers can break and rearrange, causing interference with the normal cell division of 
chromosomes by affecting the number and structure. A cell can rejoin the ends of a broken chromosome, but if there are two breaks close enough together in space and time, the broken ends from one break may join incorrectly with those from another. This can cause translocations, inversions, rings, and other types of structural rearrangement. ${ }^{13}$ Radiation is not the only mechanism by which such changes can ocs . $t$. Spontaneous mutations and chemically induced mutations have been observed.

The mutated genes from one parent can then be passed on to offspring. They typically have no effect on the offspring as long as the genes from the other parent are not mutated in the same way. However, the genes stay in the body of the offspring and are passed on to following generations. If they meet similar genes when reproducing, they would then become present in the characteristics of the offspring. ${ }^{15}$

There is no evidence that there are radiation levels below which chromosomes are not affected; however, genetic effects of radiation have never been clearly demonstrated to occur in people. ${ }^{18,19}$

\section{Health Hazards at the Fernald Site}

Aside from radiation and its effects, there are other health hazards associated with the Fernald site. In order to understand these other health hazards, it is helpful to be familiar with the terminology and laws that define and regulate these hazards.

\section{Hazardous Definitions}

Many terms refer to substances that are subject to regulation under one or more federal environmental laws. State laws and regulations also provide similar terminology that may be confused with the federally defined terms. Many of these terms appear to be synonymous and are easily confused.

A hazardous chemical, as defined by OSHA, is any chemical which is a physical hazard or a health hazard. Physical hazards include combustible liquids, compressed gases, explosives, flammables, organic peroxides, oxidizers, pyrophorics, and reactives. A health hazard, on the other hand, is any chemical for which there is good evidence that acute or chronic health effects occur in exposed people. Among the list of hazardous chemicals are carcinogens, irritants, corrosives, neurotoxins, and agents that damage the lungs, skin, eyes, or mucous membranes.

A hazardous material, as defined by the Department of Transportation, is a substance or material in a quantity and form which may pose an unreasonable risk to health and safety or property when transported in commerce. The Hazardous Materials Table, with more than 16,000 entries, includes explosives, oxidizing materials, corrosives, flammables, gases, poisons, radioactive substances, and agents capable of causing disease. 
A hazardous substance is any substance designated under Section 311 of the Clean Water Act; any element, compound, mixture, solution, or substance designated as hazardous under Section 102 of CERCLA; any listed or characteristic RCRA hazardous waste; any toxic or pollutant listed under Section 307 of the Clean Water Act; any hazardous air pollutant listed under Section 112 of the Clean Air Act; and any imminently hazardous chemical substance or mixture subject to Section 7 of the Toxic Substances Control Act.

A hazardous waste is a solid waste that must be treated, stored, transported, and disposed of in accordance with applicable requirements under Subtitle C of RCRA. Hazardous wastes may cause or significantly contribute to an increase in mortality or an increase in serious irreversible, or incapacitating reversible, illness. These kinds of wastes may also pose a substantial present or potential hazard to human health or the environment when improperly treated, stored, transported, or disposed of, or otherwise managed. The four characteristics of hazardous waste are ignitability, corrosivity, reactivity, and toxicity. All RCRA Subtitle $\mathrm{C}$ hazardous wastes are also CERCLA hazardous substances. ${ }^{20}$

\section{Laws Regulating Health Hazards}

Some of the laws that regulate health hazards are:

- CERCLA,

- RCRA,

- Toxic Substances Control Act (TSCA), and

- The Clean Air Act.

CERCLA defines hazardous substances and has its own reporting and response requirements when a hazardous substance released to the environment exceeds a reportable quantity. $\boldsymbol{R} \boldsymbol{C R A}$, as discussed above, defines and regulates hazardous waste.

Section 6 of TSCA authorizes USEPA to initiate civil actions regarding hazardous chemical substances or mixtures which present an imminent and unreasonable risk of serious or widespread injury to health or the environment. There is no "list" of imminently hazardous chemical substances or mixtures, but USEPA currently regulates PCBs, fully halogenated chlorofluoroalkanes, asbestos, and hexavalent chromium under Section 6 of TSCA.

Under the Clean Air Act, National Emission Standards for Hazardous Air Pollutants (NESHAP) are established. There are many hazardous air pollutants, including asbestos, benzene, beryllium, coke oven emissions, inorganic arsenic, mercury, radionuclides, and vinyl chloride. 


\section{Types of Health Threats}

There are many types of potential health threats (aside from the radioactive risks already discussed) related to the hazardous substances at the site. They should all be addressed and understood by both area residents and onsite workers so the substances may be avoided whenever possible. Carcinogens, corrosives, explosives, flammables, irritants, and poisons/toxins all have the potential to do harm.

Carcinogens are substances that have the potential to cause cancer. A common carcinogen located at the Fernald site is asbestos. When asbestos particles are inhaled into the lungs, they may damage the alveoli (the air sacs lining the lungs). This damage makes the lungs more susceptible to cancer, especially in smokers.

When a chemical causes a substance to wear away or deteriorate, it is said to be corrosive. Many common chemicals are potentially corrosive. For example, vapors from ammonia may be corrosive to the eyes, respiratory system, and other moist tissues. Blindness may result from a large exposure to these vapors.

Explosions can occur in many situations. If an unstable solid or liquid changes suddenly into a quickly expanding gas, especially in a tightly closed container, an explosion can occur. Rapid nuclear fission may also cause a substance to explode. During these explosions, energy is released, often in the form of heat and sometimes radiation. This energy release may cause burns to exposed skin or injury resulting from the impact of debris.

Flammable materials are any materials which can be easily set on fire and burn readily. Paints, gases, and fuels are common flammable materials at the site. Hydrogen, for example, is a very flammable gas. An obvious health hazard associated with flammable material is the potential for burns.

An irritant is a substance which causes an organ or any part of the body to become inflamed or sore. A common solvent used at the site, 1,1,1-trichloroethane, can be an irritant to the skin and the eyes upon contact.

Poisons and toxins are substances that may cause illness or death when ingested or absorbed into the body. Nearly all chemicals have the potential to become poisonous or toxic when used improperly or in excessive amounts. A toxin that destroys nerves or nervous tissue is called a neurotoxin.

The environmental monitoring data are presented in chapters Four, Five, and Six, and the Radon Monitoring Program is discussed in Chapter Eight. Along with this information are descriptions of the methods used to gather data. Using this information and a basic understanding of radiation, we can proceed to Chapter Seven for a discussion of the estimated radiation doses to which the people near the site might be exposed and how these results were calculated. 


\section{Environmental Compliance Summary}
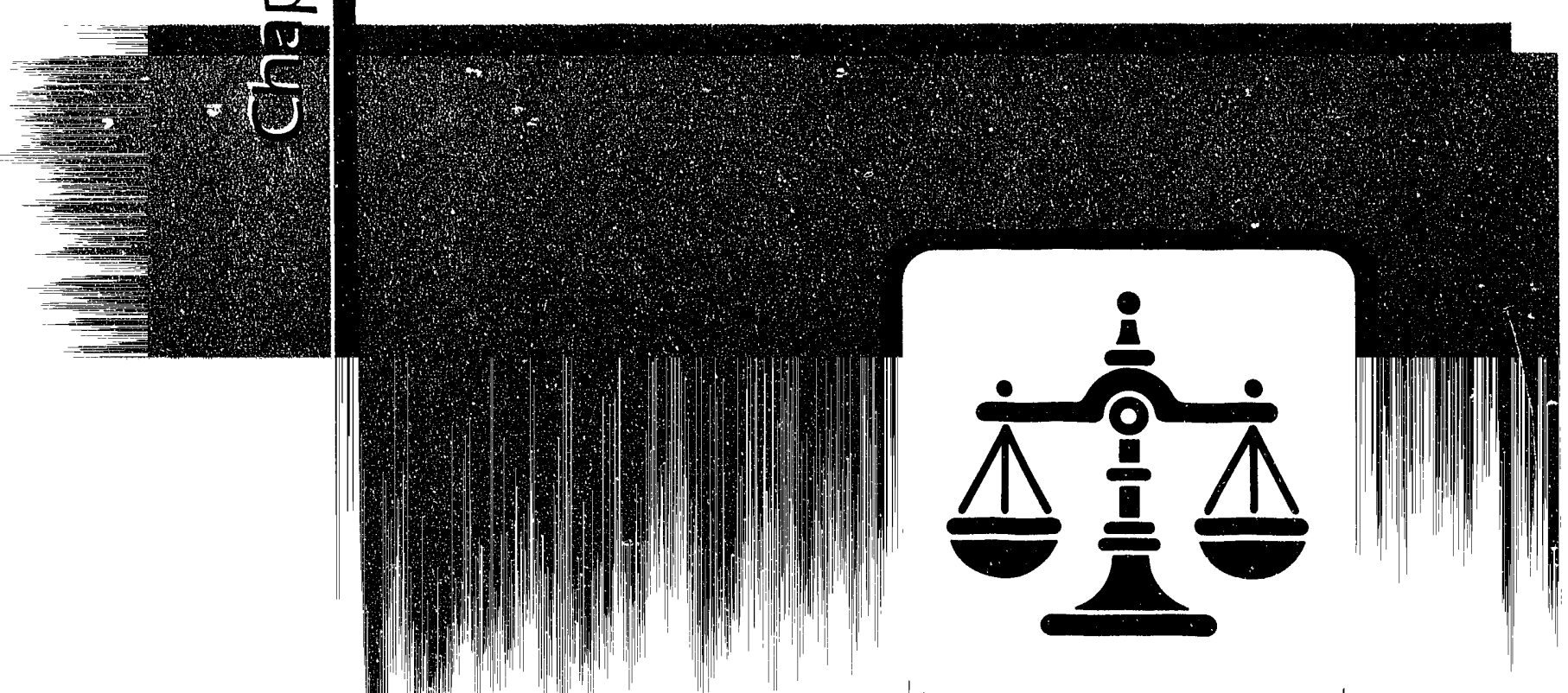


\section{Environmental Compliance Summary}

The Fernald site must comply with environmental requirements established by a number of agencies governing daily operations at the site. These requirements fall into four general categories:

- Requirements imposed by federal statutes and regulations,

- Requirements imposed by state and local statutes and regulations,

- Requirements imposed by DOE orders and directives, and

- Site-specific requirements imposed through agreements with regulatory agencies.

Because these requirements are initiated by several different sources, enforcement likewise falls under several federal, state, and local agencies. OEPA is the primary agency that issues permits, reviews compliance reports, inspects facilities and operations, and oversees compliance with applicable regulations. USEPA Region $V$ governs the CERCLA process with the cooperation and active participation of OEPA. In addition, USEPA develops, publishes, and enforces environmental protection regulations and technology-based standards as directed by statutes passed by Congress. For some programs, USEPA has delegated the regulatory authority to the State of Ohio. For these programs, OEPA promulgates state regulations which must be at least as stringent as the federal requirements and may exceed the federal requirements. The Fernald site also operates under a number of legal agreements with USEPA Region $V$ and OEPA. DOE Headquarters issues directives to its field offices and conducts compliance audits. In addition, the Fernald site conducts internal audits.

The Fernald site's progress toward achieving full compliance with all environmental regulations is summarized in this chapter. It is divided into three sections - Compliance Status, Current issues and Accomplishments, and Environmental Permits. This summary covers the period from January 1, 1992, to April 1, 1993, as required by DOE reporting requirements. 


\section{Compliance Status}

This section presents a summary of the Fernald site's status with many of the regulations with which the site must comply.

\section{CERCLA}

The Fernald site is on the National Priorities List (NPL) of sites requiring environmental cleanup under the Comprehensive Environmental Response, Compensation, and Liability Act (CERCLA). Consistent with the requirements of Section 120 of CERCLA, a Consent Agreement was signed by DOE and USEPA in April 1990 and was amended in September 1991. The Consent Agreement defined five operable units to more effectively manage the ongoing CERCLA cleanup. These operable units are as follows:

- Operable Unit 1 - Waste Pit Area,

- Operable Unit 2 - Other Waste Units,

- Operable Unit 3 - Former Production Area,

- Operable Unit 4 - Silos 1 - 4, and

- Operable Unit 5 - Environmental Media.

The Amended Consent Agreement:

- Established new schedules for the completion of the ongoing RI/FS;

- Identified 14 new removal actions, which are tasks undertaken to abate immediate threats to the environment and health;

- Established a Sitewide Operable Unit (encompassing operable units 1 through 5) to ensure that actions taken under the individual operable units are protective of human health and the environment on a sitewide basis; and

- Established a mechanism for the site to add additional removal actions on a yearly basis.

In December 1992, comments were received from USEPA on the Remedial Investigation (RI) report for Operable Unit 2, including requirements for additional field investigations. The site agreed that additional investigation was needed and requested an extension of the schedule imposed by the Consent Agreement for submittal of the RI report. The site completed an informal dispute resolution with USEPA. As a result of this dispute resolution, USEPA has accepted the revised schedule for submittal of the RI Report and for submittal of the Feasibility Study and Record of Decision. USEPA also agreed that, as an alternative to paying a large stipulated penalty, DOE will fund and implement a Supplemental Project in Operable Unit 5 to provide additional treatment for uranium removal from Fernald site wastewater streams.

With the exception of the Operable Unit 2 RI report, the Fernald site met all requirements of the Amended Consent Agreement between January 1, 1992, and April 1, 1993. 


\section{SARA}

The Superfund Amendments and Reauthorization Act of 1986 (SARA) was written to clarify and expand CERCLA ("Superfund") requirements. More detailed regulations for reporting inventories and releases of hazardous substances to federal, state, and local authorities are included in these amendments as outlined below.

The SARA Title III, Section 312 report for 1992 was completed and submitted to OEPA by the March 1, 1993, deadline. This report lists the amount and location of hazardous substances stored or used in amounts greater than the minimum reporting threshold. A computerized chemical tracking system is being installed which will provide better information on all chemicals used and stored at the site.

The SARA Title III, Section 313 Toxic Chemical Release Inventory Report was submitted to OEPA and USEPA on July 1, 1992. This report is required for any toxic chemical that is manufactured, processed, or otherwise used at a facility in quantities greater than a minimum reporting threshold. A report was completed for Hydrochloric Acid, Methanol, and Sulfuric Acid which were processed and/or otherwise used at the Fernald site. The Toxic Chemical Release Inventory Report lists routine and accidental releases, as well as information about the activities, uses, and waste for each reported toxic chemical. The report also included source reduction and recycling information as required by the Pollution Prevention Act of 1990.

For any offsite release exceeding a reportable quantity (RQ), SARA Title III, Section 304 requires immediate notifications to Local Emergency Planning Committees and State Emergency Response Commissions. All releases are evaluated to ensure that proper notifications are made in accordance with SARA. In addition to SARA, releases are also evaluated for notification under CERCLA Section 103, RCRA, TSCA, the Clean Air Act, the Clean Water Act, Ohio environmental laws and regulations, and the Ohio Fire Code. Department of Transportation regulations are also considered. Depending on the respective requirement, notifications may also be made to the National Response Center, OEPA, USEPA, the Ohio State Fire Marshal, or a local fire official.

During the early part of 1992 , the Fernald site continued to evaluate weight discrepancies discovered during overpacking operations and reported those that exceeded an RQ as potential releases. Drum weight discrepancies occur when a drum containing a measured amount of waste indicates an unexplained weight loss upon being reweighed. In May 1992, the drum weight discrepancy reporting policy was revised to reflect the fact that improvements in drum waste management, such as improved inspections, storage improvements, and overpacking of deteriorated drums, have greatly increased the likelihood that these inventory discrepancies are due to administrative errors rather than an actual release to the environment. The following is a summary of reported releases. 
From January 1, 1992, through April 1, 1993, a total of seven releases to the environment were reported to offsite agencies. Of these seven, four were in regard to drum weight discrepancies. Although the discrepancies were most likely due to evaporation or errors in weighing, the possibility exists that some materials may have leaked out of the drums stored on open pads. These four drum weight discrepancies resulted in reported potential releases of:

- $37 \mathrm{~kg}$ (81 pounds) of trash containing arsenic, lead, selenium, benzene, and spent solvents (over two separately reported releases); and

- $30 \mathrm{~kg}$ (66 pounds) of spent solvents containing 1,1,1-trichloroethane and benzene (over two separately reported releases).

In January 1992, coal in a storage bin at the Boiler Plant spontaneously ignited and continued to burn for 26 hours. A release to the atmosphere of $60 \mathrm{~kg}$ (130 pounds) of sulfur dioxide, which was produced by combustion of coal, was reported.

In March 1992, seven uranium ingots were dropped onto a plant driveway as they were being moved within the former production area. The weight of these ingots, $1,841 \mathrm{~kg}$ (4,050 pounds), was reported as a release to the environment (according to USEPA definition), even though the material and its residues did not leave the concrete driveway and were removed immediately.

In August 1992, approximately 0.95 liter (1 quart) of antifreeze containing approximately $0.454 \mathrm{~kg}$ ( 1 pound) of ethylene glycol was released to the environment when a site vehicle boiled over during a drill exercise. An RQ for ethylene glycol has not been set, so the default is 1 pound, the approximate amount found in a quart of antifreeze.

\section{RCRA}

The Resource Conservation and Recovery Act (RCRA) regulates treatment, storage, and disposal of hazardous waste. OEPA has authority to enforce most RCRA regulations for the Fernald site.

Past operations and ongoing cleanup activities generate both hazardous wastes and mixed wastes (containing hazardous and radioactive components). As a management practice, some wastes are accumulated in quantities less than 55 gallons at the point of generation in locations known as satellite accumulation areas. The waste may remain in these areas until 55 gallons have been accumulated, at which time it must be moved to an approved RCRA storage area.

There are a limited number of facilities in the United States that can treat or dispose of mixed waste; a final disposal site for all Fernald site mixed waste is not yet available. Therefore, although some waste was shipped to the $\mathrm{K}-25$ incinerator in Oak Ridge in 1987 and incinerated in 1991, most of the mixed waste currently remains onsite. 
In addition to being regulated by state and federal legislation, RCRA waste is handled according to the 1988 Consent Decree between the State of Ohio and DOE. In 1990, negotiations between the State of Ohio, DOE, and the former operating contractor (Westinghouse Environmental Management Corporation (WEMCO)) resulted in the Proposed Amended Consent Decree (PACD). The PACD was signed by all parties in January 1993 and became known as the Stipulated Amendments to the Consent Decree (SACD). The SACD outlines many requirements, including:

- Hazardous waste characterizations,

- A Drum Management Plan,

- Closure pians for Underground Storage Tank 5 and Waste Pit 5 ,

- A timetable for submitting revised RCRA Part A and Part B permit applications, and

- A report of all known hazardous waste management units.

In accordance with the PACD, characterization of a specified population of waste materials was completed in October 1992. This characterization program encompassed both process knowledge and chemical analysis requirements, including:

- Process knowledge determinations for 1,800 drums of suspect materials in RCRA storage,

- Initial process knowledge determinations for the 8,000 drums of material not affected by the Hazardous Waste or Solid Waste Management Unit (HWMU or SWMU respectively) review,

- Initial process knowledge determinations for the 8,000 drums of material affected by the HWMU/SWMU review, and

- A Waste Determination Plan, approved by OEPA, which identified the approach the site will take in conducting the characterization program.

The hazardous waste characterizations summarized above were completed as scheduled. Quarterly reports have been submitted to OEPA, as specified by the PACD, since January 1991.

In February 1992, the Fernald site received a letter from OEPA identifying several violations of the Ohio Adminis ${ }^{\wedge}$ ative Code within the RCRA Groundwater Assessment Monitoring Program. The violations were noted as a result of OEPA review of the 1989 and 1990 RCRA Annual Groundwater Quality Assessment Reports and concerned the determination of the rate and extent of migration of hazardous waste constituents in groundwater, the identification of Waste Pit 4 waste constituents, the site's sampling methodology and procedures, and the suitability of upgradient monitoring wells. Written responses to two of the violations were provided to OEPA in March and April 1992. A response was sent to OEPA in May 1992, which summarized the site's effort to determine the rate and extent of contaminant migration and disagreed with the OEPA that the site was in violation. No response was received by the end of this reporting period. 
In August 1992, OEPA notified the Fernald site of two violations and five issues as a result of their RCRA compliance inspection of the Fernald site in June and July 1992. A response was submitted to OEPA in September 1992. The two violations concerned Land Disposal Restriction (LDR) storage and facility inspection requirements. These issues are:

- Nitric acid tank car and hydrofluoric (HF) tank schedules,

- Container stacking,

- Storage areas' fire protection, and

- Two issues on container management.

\section{Clean Air Act}

In Ohio, authority to enforce requirements of the Clean Air Act has been delegated by USEPA to OEPA, except for the enforcement of the National Emission Standards for Hazardous Air Pollutants (NESHAP) for radionuclides and radon. Most Fernald site air emission sources are regulated by USEPA as radionuclide sources and by OEPA as particulate and/or chemical emission sources.

The NESHAP standard for radionuclide air emissions from DOE facilities imposes a limit of 10 mrem per year on the effective dose equivalent (EDE) to the maximally exposed offsite resident due to all emissions (with the exception of radon) from the facility in a single year. This standard also imposes requirements for continuous monitoring of certain emission sources and periodic confirmatory measurements of smaller sources.

Because the Fernald site is a former uranium processing plant, uranium is the radioactive particulate of most concern in monitoring airborne emissions. The Fernald site estimated that airborne uranium emissions for 1992 totalled $0.23 \mathrm{~kg}$

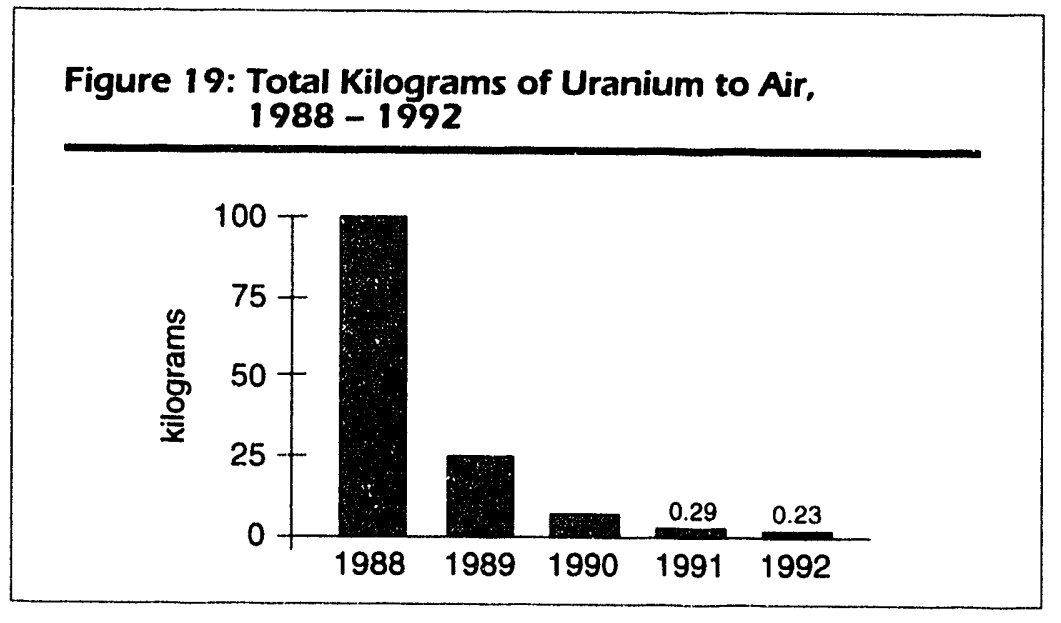
( 0.51 pound). This is a $21 \%$ reduction from $0.29 \mathrm{~kg}$ ( 0.64 pound) estimated in 1991 (see Figure 19). Airborne uranium emissions have been steadily dropping since processing operations were discontinued in 1989.

During 1991, the State of Ohio regulation limiting sulfur dioxide emissions was revised to reduce the allowable $\mathrm{SO}_{2}$ emission level from the Fernald site's coal-fired burners from $0.91 \mathrm{~kg}(2.0$ pounds) $\mathrm{SO}_{2} / \mathrm{MMbtu}$ heat input to $0.60 \mathrm{~kg}$ (1.32 pounds) $\mathrm{SO}_{2} / \mathrm{MMbtu}$ heat input to be effective in 1993. In response, the Fernald site began purchasing a low-sulfur coal in 1991 and has been in compliance with the reduced limit ever since. 
Asbestos - In order to identify the location of asbestos-containing materials, a site survey was completed in February 1992. Locations of all asbestos-containing material were recorded on site diagrams. The material was assessed for its hazard potential, and work orders were written and implemented to repair or remove damaged asbestos.

To control the asbestos identified as hazardous by the site survey, a specially trained and equipped "Asbestos Team" encapsulated over 2,300 linear meters (7,500 linear feet) of damaged pipe insulation and removed more than 980 linear meters $(3,180$ linear feet) that were beyond repair.

A Transite Fiber Migration Study was completed in February 1992. This study determined that asbestos fibers are being released from the transite panels that were used for most roofs and exterior walls onsite. The fiber release does not exceed any regulatory limits. Fibers have accumulated in soil and concrete surfaces surrounding transite clad buildings and in the gutters and stormwater system.

A Transite Fiber Stabilization Study was completed in September 1992. The purpose of this study was to examine why asbestos fibers were migrating from transite and what can be done to prevent such releases. The first test application of several products to prevent asbestos fiber migration was completed in December 1992; the durability of these products will be evaluated during 1993.

In December 1992, a procedure was developed and implemented to ship nonradioactive asbestos waste to a local landfill. This resulted in considerable time and cost savings compared to shipping the waste to the Nevada Test Site (NTS).

\section{Clean Water Act}

Under the Clean Water Act, the Fernald site is governed by National Pollutant Discharge Elimination System (NPDES) regulations that call for the control of discharge of nonradioactive pollutants to Ohio waters and the monitoring of industrial stormwater discharges to public waters.

\section{NPDES Effluent Regulation}

The NPDES permit issued by the State of Ohio specifies discharge and sampling locations, sampling and reporting schedules, and discharge limitations. The current permit specifies seven regulated monitoring locations; two are external discharges directly to Ohio waters and five are internal effluent streams which lead to one of the external discharges (see Figure 20). 


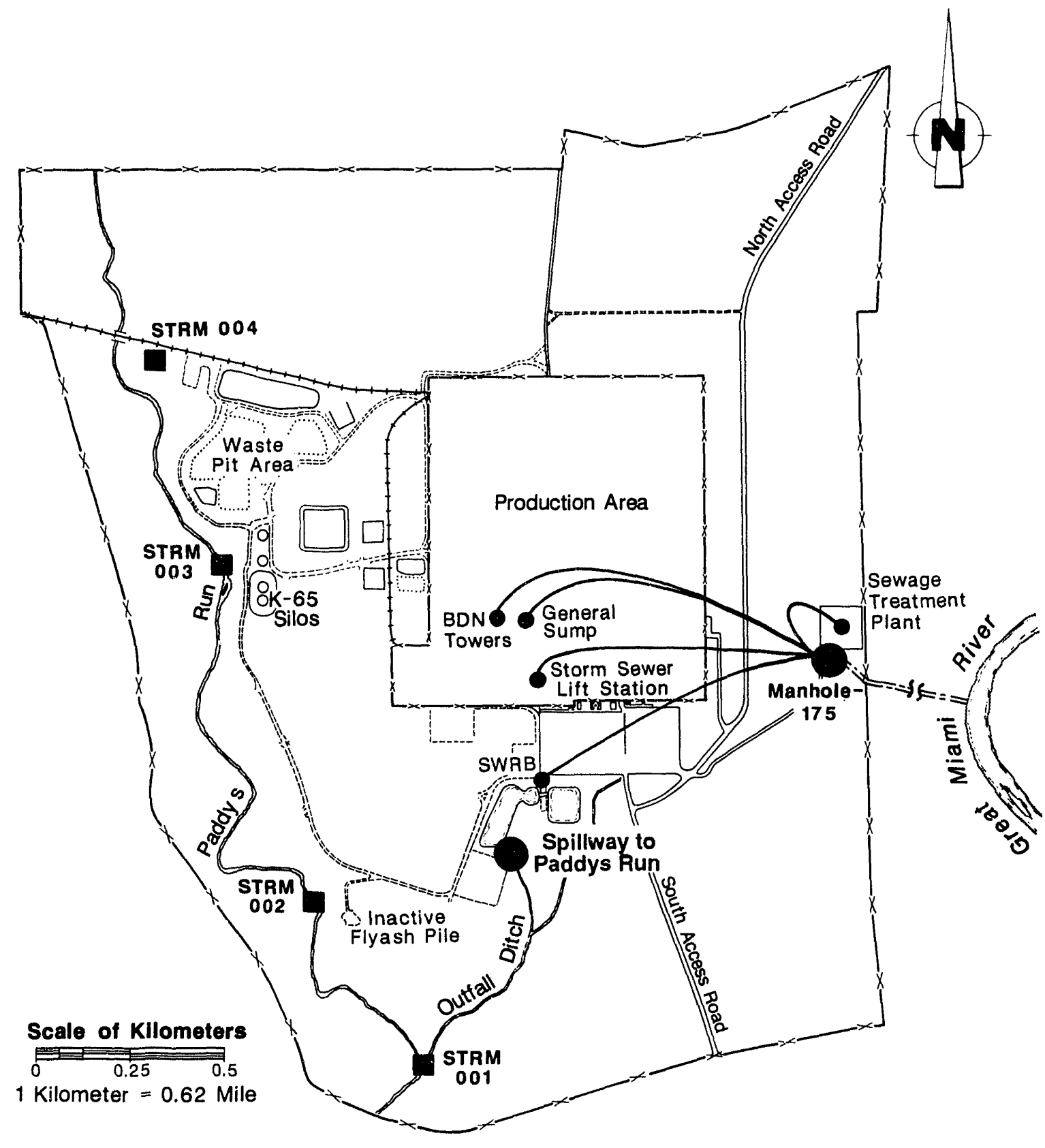

LEGEND

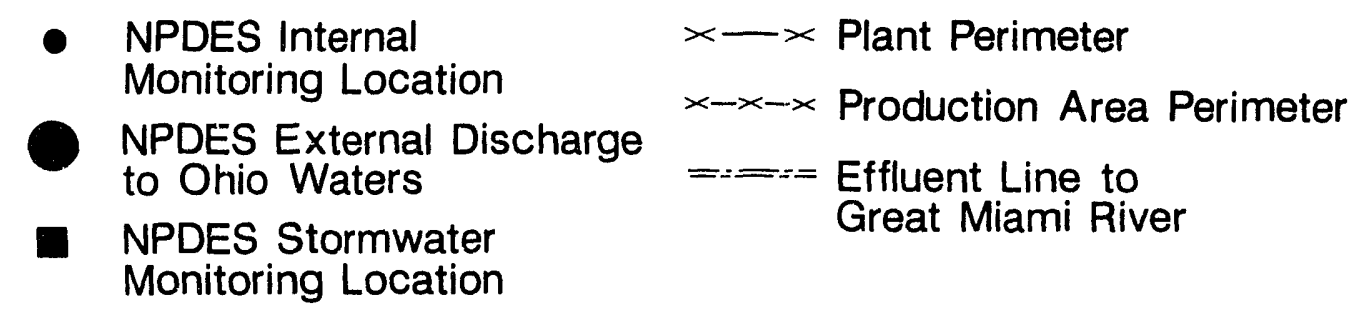


Between January 1, 1992, and April 1, 1993, the Fernald site was compliant with the discharge limits specified by the NPDES permit $99.7 \%$ of the time. Of the 7,780 monitoring results between January 1, 1992 and April 1, 1993, only 23 were not within the discharge limits specified by the permit. All noncompliances were shortduration exceedances of limits, such as $\mathrm{pH}$, at internal monitoring points. Permit limits at the discharge to the Great Miami River (Manhole-175) were met without exception.

\section{NPDES Stormwater Regulation}

New NPDES rules were established by USEPA in 1990 to regulate industrial stormwater discharges. Under these new rules, permit applications for point source discharges of stormwater to public waters from certain categories of industrial activity were required to be submitted to OEPA by October 1, 1992. A point source discharge is defined as a discharge through a pipe, ditch, channel, or other discernible conveyance.

As part of preparing an application for Fernald site stormwater discharges, onsite runoff patterns were mapped; it was identified that flow is generally to the west and south. Four NPDES stormwater monitoring locations have been marked where stormwater flows into Paddys Run. A permit application for these discharges was submitted to OEPA in September 1992.

These monitoring locations are:

- STRM 001 - Collecting runoff from the east and south;

- STRM 002 - Collecting runoff from the Inactive Flyash Pile;

- STRM 003 - Collecting runoff from the western property perimeter, excluding the waste management facilities; and

- STRM 004 - Collecting runoff from the northern property perimeter.

Stormwater runoff from the majority of the former Production Area is already collected through the stormwater system, monitored at internal outfalls, and discharged through Manhole-175 to the Great Miami River in accordance with the existing NPDES permit. Collection of runoff in the waste pit area is provided by the recently completed Waste Pit Area Stormwater Runoff Control Removal Action. Runoff from the remainder of the former production area will be directed to the storm sewer system upon completion of the Collect Uncontrolled Production Area Northeast Removal Action, which is scheduled for 1993.

During a May 1992 inspection by USEPA, Fernald site personnel informed the inspector that the Spill Prevention Control and Countermeasure (SPCC) Plan had last been updated in February 1992 and that a revision to the plan was in process in order to incorporate updated status of secondary containments for above-ground storage tanks and also to reflect movement of some PCB materials from Building 79 to Building 81.40 CFR 112.1 requires that SPCC Plans be updated whenever there is a change at the facility that impacts the SPCC Plan. In March 1993, USEPA 
notified the site that the changes mentioned at the inspection not yet incorporated into the plan constituted a violation of 40 CFR 112 . The letter directed that either an updated SPCC Plan or a commitment to a program and schedule to complete the revision was to be submitted by April 15, 1993.

At the time the USEPA letter was received, a revision to incorporate the referenced changes had been compiled and was in final internal review in preparation for being issued. A schedule for its issuance was provided to USEPA on April 15, 1993.

\section{Safe Drinking Water Act}

Safe Drinking Water Act (SDWA) regulates generation and treatment of drinking water supplied to the public. The Fernald site drinking water system is regulated by OEPA as a non-transient, non-community public drinking water system. An inspection of the Fernald site drinking water program conducted by OEPA in 1992 identified no deficiencies in the program.

New monitoring regulations put forth between 1986 and 19rs1 will require more extensive monitoring of the Fernald site drinking water system beginning in July 1993. In response to these new regulations, 1992 SDWA ac ivities focused on planning the implementation of the increased monitoring requirements beginning in mid-1993.

\section{Toxic Substances Control Act}

The Toxic Substances Control Act (TSCA) regulates the manufacturing, storage, and disposal of toxic materials. Under TSCA, USEPA regulates polychlorinated biphenyl (PCB) materials at the Fernald site. The site ships non-radiologically-contaminated PCB material to commercial facilities for disposal, while radioactively-contaminated PCB materials from past operations and maintenance activities are stored onsite. One non-radioactive PCB shipment was made to a facility in Deer Park, Texas, during the January 1, 1992, through April 1, 1993, period.

The radioactively contaminated PCB materials are stored in Building 81 in compliance with TSCA requirements. A document log is kept, and an annual PCB report is completed by July 1 of each year. Forty-eight drums of radioactive PCB waste remain onsite due to the lack of treatment and disposal facilities.

A Notice of Noncompliance (NON) was received from USEPA due to an inspection conducted on May 28, 1992. The NON cited noncompliance due to the 1990 PCB Annual Report encompassing the time period January 1, 1990, to December 31, 1990, when it should have reflected the period February 5, 1990, to December 31, 1990, per 40 CFR 761.180(a). The heading on the 1990 PCB Annual Document Log was corrected to reflect the appropriate period (the 1990 PCB Annual Report was an attachment to the 1990 PCB Annual Document Log). The body of the 1990 PCB Annual Document Log contained no activity that occurred during the period of 
January 1 to February 5, 1990, and there were no changes to the body of the 1990 PCB Annual Document Log. This information was sent to USEPA in March 1993.

\section{Ohio Solid Waste Act}

This 1988 act and its subsequent revisions regulate infectious waste. The Fernald site is considered a small generator under Ohio law because the medical department generates less than $23 \mathrm{~kg}$ (50 pounds) of infectious waste, such as hypodermic needles, per month. Therefore, generator registration with the state is not required. All infectious wastes generated in the medical department are transported to a licensed treatment facility for incineration. Fernald site personnel conduct annual surveillances of the onsite medical department, the transporter, and the treatment facility to ensure that the waste is properly managed.

\section{Federal Insecticide, Fungicide, and Rodenticide Act}

Under the Federal Insecticide, Fungicide, and Rodenticide Act (FIFRA), USEPA regulates the use of insecticides, herbicides and rodenticides. The majority of Fernald site rodenticide and herbicide applications are performed by subcontractors according to state and federal requirements. Applications are made for pest control in food areas, as well as for weed control along railroad tracks. An inspection by USEPA in 1992 identified no deficiencies. Site personnel are implementing actions to ensure that historical information is available on the identification and location of chemicals used at the site.

\section{National IEnvironmental Policy Act}

The National Environmental Policy Act (NEPA) requires a formal evaluation of environmental impacts before any action, such as a construction project, is initiated by a federal agency. DOE publishes federal regulations to implement NEPA requirements at its facilities. Fernald site NEPA activities continue to focus on the integration of NEPA with CERCLA. A total of six removal actions were deemed to be Categorical Exclusions (CXs) and of them, five were approved as such. A Categorical Exclusion for limited Safe Shutdown activities is expected to be approved in mid-1993. Three Findings of No Significant Impact (FONSIs) were also submitted for the Safe Shutdown and Management of Contaminated Structures Removal Actions and for the Central Storage Facility.

In addition to the removal actions deemed as CXs, 15 other CXs were approved in 1992 and an additional seven CXs were submitted before the end of the first quarter of 1993. Other NEPA activities between January 1, 1992, and April 1, 1993, included the initiation of an Environmental Impact Statement (EIS) and Environmental Assessments (EAs) as follows:

- Receipt of approval of the Implementation Plan for the Operable Unit 4 Feasibility Study - Environmental Impact Statement (FS - EIS) and initiation of preparation of the FS - EIS; 
- Initiation of a Proposed Plan/EA for the Operable Unit 3 Interim Record of Decision;

- Preparation of an EA for the remediation activities at the RMI Titanium Company (this site was formerly operated under subcontract to the Fernald site to extrude uranium billets produced at the Fernald site; the site is now managed by the DOE Chicago Field Office);

- Preparation of an EA/FONSI for the new Fernald site Boiler Plant; and

- Public Interactive Workshops for the Programmatic EIS (for the DOE complex) in March and September 1992.

\section{Endangered Species Act}

The Endangered Species Act requires the protection of any endangered species found at the site. In addition, USEPA ecological guidelines direct CERCLA sites to identify any threatened species present at the site or in offsite areas affected by site activities. Critical habitats that may support any threatened or endangered species must be recognized as well. The baseline ecological survey conducted by Miami University (Oxford, Ohio) in 1986 and 1987 found no federal or state endangered species at the Fernald site. However, the Miami University study, as well as other studies, have identified suitable habitats at the Fernald site for the following endangered species:

- The Indiana bat (Myotis sodalis) is a federal- and state-listed endangered species. While none have been seen at the Fernald site, some areas within the property along Paddys Run are considered good habitat for the Indiana bat. There is a breeding colony on nearby Banlick Creek, a tributary to the Great Miami River near Ross, Ohio;

- The cave salamander (Eurycea lucifuga) is on Ohio's endangered species list and has been found in several locations close to the Fernald site. There are areas along Paddys Run which are suitable habitat for the cave salamander, but none have been sighted; and

- Discussions with EPA in 1992 resulted in the identification of one additional federal- and state-listed endangered species, running buffalo clover (Trifolium stoloniferum), which may occur on the Fernald site. Running buffalo clover has not been identified at the Fernald site, but a population was identified less than $8 \mathrm{~km}$ ( 5 miles) southwest of the Fernald site at Miami Whitewater Forest.

DOE and FERMCO plan to update the baseline ecological survey. A Public Water Supply Project (discussed further in Chapter Six) involves the installation of water pipelines along approximately $23 \mathrm{~km}$ (14 miles) of county and state roadways. Along the route of the pipeline are areas which may include possible critical habitats. A threatened and endangered species survey for the project was completed in April 1993. 


\section{Executive Order 11990 , "Protection of Wetlands"}

This executive order is a directive requiring federal agencies to institute programs to identify and protect wetlands. A study of the Fernald site conducted in 1990 delineated wetlands onsite, most of which were man-made. Since restoration activities have the potential to alter or influence these wetland areas, all restoration projects and activities are reviewed for their potential impact. An updated site-wide delineation of wetlands, performed in accordance with the U.S. Army Corps of Engineers Wetland Delineation Manual, was completed in March 1993.

Also, a wetlands assessment will be completed for the jointly funded Hamilton County Public Water Supply Project. Approximately 1.5 acres of wetlands lie along the routes of this project.

\section{Executive Order 11988 , "Floodplain Management"}

This Executive Order instructs federal agencies to avoid construction in river floodplains. A notification of Floodplain Involvement was published for the South Plume Removal Action. A Floodplain Statement of Findings was published in the Federal Register on January 24, 1992. The statement indicated that even though the South Plume Removal Action had been identified to be within the 100-year floodplain of the Great Miami River, there was no practicable alternative to the proposed removal action.

Portions of the Public Water Supply Project have also been identified to be within the 100-year floodplain of the Great Miami River, but they are within existing roadway easements. The installation of the pipeline is expected to result in no permanent elevation changes to the floodplain. Once the pipeline is installed, the disturbed areas will be regraded and seeded. A floodplain assessment and a statement of findings for the project will be completed in mid-1993.

\section{National Historic Preservation Act}

Pursuant to the National Historic Preservation Act, construction activities are required to take into account the impact on any local historic or cultural resources. Consultation and coordination with federal and state preservation agencies are required when cultural resources are in danger of being disturbed.

Consultation with the State Historic Preservation Officer (SHPO) had established exclusion areas (within the production area and near the K-65 silos) of the 425hectare (1,050-acre) site. It was determined that these areas had already been sufficiently disturbed, so there would be no requirement to consult the SHPO for new actions within these areas onsite. However, a survey and consultation for land disturbance activities outside these designated areas and offsite are required. To address such activities, a Cultural Resource Management Plan was drafted and is being revised for submittal to the SHPO. 
The South Groundwater Contamination Plume Removal Action required an archeological survey and consultation. Archeological surveys were conducted to verify that the South Plume projects will not adversely affect cultural resources. The reports identified no known resources within the project area.

The Public Water Supply Project involves the installation of water pipelines along approximately $23 \mathrm{~km}$ (14 miles) of state and county roadways in Hamilton and Butler Counties. An archeological survey for this project will be completed in 1993 to determine if there will be any impact on historic or cultural resources.

\section{Current Accomplishments and Issues}

This section presents significant compliance-related accomplishments and issues for 1992 and the first quarter of 1993.

\section{CERCLA}

In the course of a RI/FS effort, conditions are occasionally identified that call for immediate action in order to address releases or potential releases of hazardous substances. These actions, called removal actions, are coordinated with USEPA and OEPA.

\section{Compieted Removal Actions}

Through April 1, 1993, the Fernald site had identified 30 removal actions. Four of these had been completed prior to this reporting period. The following six removal actions were completed between January 1, 1992, and April 1, 1993.

Waste Pit Area Stormwater Runoff Control Removal Action - After analysis showed that stormwater runoff from the waste pit area had contaminated the surface soils, the glacial overburden, and the groundwater beneath the waste pits, this removal action was initiated. Installation of a runoff control collection system was completed in July 1992. This system will collect the runoff and allow it to be treated in the existing wastewater treatment facilities.

Inactive Flyash Pile Removal Action - This removal action focused on isolated areas of radiological surface contamination in the Inactive Flyash Pile and other South Field disposal areas. The removal action was completed when a small amount of contaminated debris (soil and transite) was removed from the Inactive Flyash Pile and placed in appropriate containers for storage pending final disposition.

Pit 5 Experimental Treatment Facility Removal Action - This treatment facility was built in 1984 to test the feasibility of thermal drying for sludge material from Waste Pit 5. This removal action was completed ahead of schedule in March 1992 when the facility was dismantled and the building materials and sludge were packaged for safe storage pending final disposition. 
Control Exposed Material in Pit 5 Removal Action - Exposed materials were repositioned within the pit so they would be covered by water. This prevents them from being blown by the wind and released to the environment. Dredging was completed December 16,1992. Other field activities, including patching separations in the pit liner, were completed in January 1993, ahead of the scheduled completion date of February 3, 1993.

Expedited Silo 3 Dust Collector Removal Action - The removal of an out-ofservice dust collector and hopper assembly from Silo 3 in January 1992 marked the completion of this removal action. All pathways were permanently sealed to prevent the release of silo contents to the atmosphere.

Inactive Flyash Pile Removal Action - This removal action was completed in the fall of 1992 when a small amount of contaminated debris was removed from the Inactive Flyash Pile and placed in appropriate containers for storage pending final disposition. This removal action was in addition to the Inactive Flyash Pile Controls Removal Action that was completed in December 1991.

\section{Ongoing Removal Actions}

Twenty removal actions are currently in progress. The following eleven removal actions are already underway to alleviate immediate threats to the environment:

- Contaminated Water Under Fernald Site Buildings,

- South Groundwater Contamination Plume,

- Plant 1 Pad Continuing Release,

- Removal of Waste Inventories,

- Safe Shutdown,

- Plant 1 Ore Silos,

- Contaminated Soils Adjacent to Sewage Treatment Plant Incinerator,

- Scrap Metal Pile,

- Collection of Uncontrolled Production Area Runoff,

- Stabilization of Uranyl Nitrate Inventories, and

- Asbestos Removals.

Chapter Eleven, Remedial Investigation and Feasibility Study, presents more information on the activities concerning the ongoing removal actions listed above. The remaining nine removal actions, listed below, are still in the planning and implementation process:

- Improved Storage of Soil and Debris,

- Plant 7 Dismantling,

- Waste Pit Area Containment Improvement,

- Removal of the Pilot Plant Sump,

- Cleanup of Nitric Acid Tank Car and Surrounding Area,

- Management of Contaminated Structures,

- Stabilization of Thorium Nitrate, 
- Contamination at the Fire Training Facility, and

- Temporary Nitrate Storage Tanks.

Inactive Flyash Pile Time-Critical Removal Action - This time-critical removal action has recently been identified for near-term implementation and therefore is not included in the previously discussed 30 removal actions. The action is proposed to stabilize the bank of Paddys Run and eliminate the threat of undercutting the Inactive Flyash Pile. The Removal Site Evaluation was submitted in draft to DOE, and an Action Memorandum was issued in March 1993. USEPA and OEPA have concurred. The project consists of installing a weighted berm for bank stabilization. The U.S. Army Corps of Engineers has issued a letter stating the project qualifies under Nationwide Permit \#13. The target date to begin work is the week of April 19, 1993. The project will be evaluated upon completion to determine if follow-up work will be necessary in the form of an additional removal action.

\section{Other CERCLA Accomplishments and Issues}

Operable Unit 4 Treatability Study Report - The cementation study in progress involves the evaluation of different cement and additive formulations. This study focuses on producing the best mix design which retards contaminant migration and provides acceptable physical properties such as volume and strength. Testing for durability, radon emanation, and radium leaching is also in progress. The Operable Unit 4 Treatability Study Report is on schedule, to be submitted to USEPA in May 1993.

Operable Unit 5 Treatability Study - The Fernald site is installing a pilot unit in Plant 8 at the Fernald site to demonstrate the feasibility of soil washing as a remedial technology for cleaning site soils. Data generated from the study will be used to support the Operable Unit 5 Feasibility Study and subsequent remedy selection.

\section{NEPA}

NEPA coordination at the site is being revised to oversee activities more efficiently. Administrative activities in 1992 and the first quarter of 1993 include:

- Revision of DOE site office NEPA procedures to reflect the Final Rule and Notice, 57 Federal Register 15122 et al., No. 80;

- Revision of the NEPA site documents and training program to ensure integration with the Project Management Procedures (PMPs) that are presently being revised and to further foster the integration of NEPA requirements with all types of activities at the Fernald site, and

- Upgrade of the NEPA database to permit site-wide access.

NEPA activities are now being carried out by site staff instead of subcontractors to improve efficiency. 


\section{RCRA}

The SACD requires that all Hazardous Waste Management Units (HWMUs) at the site be identified. As a result, the Fernald site is investigating burners, incinerators, furnaces, stills, process equipment, tank units, dust collectors, and other potential waste containment units to determine if they are HWMUs or SWMUs. A total of 53 HWMUs have been recognized, and individual schedules have been established for bringing the units into compliance.

The evaluation process, regulatory basis, and technical assumptions used to designate these units as HWMUs are being reviewed to verify that the designation of these units as HWMUs is justified or if some units should more appropriately be designated as SWMUs. If this evaluation identifies any proposed changes in designations, OEPA approval will be sought to change the designation.

\section{Thorium Management}

A Thorium Management Strategy and schedule of accomplishments were developed as part of the SACD to provide a plan to complete RCRA determinations of thorium materials and to improve the storage of thorium materials at the Fernald site. The Thorium Management Strategy was initiated as part of the SACD and is based on three primary objectives:

- To maintain environmentally stable interim storage of the thorium inventory while minimizing personnel radiation exposure,

- To implement required further actions to complete RCRA evaluations of the thorium materials, and

- To implement long-term storage and disposal alternatives.

Between January 1, 1992, and April 1, 1993, more than 1,600 drums of thorium materials were shipped to NTS. The characterization of the last 16 containers required to be further characterized in accordance with the SACD was completed in June 1992.

\section{Land Disposal Restriction W/aste}

The Fernald site stores mixed waste subject to the RCRA Land Disposal Restrictions (LDR). These regulations currently prohibit the storage of certain hazardous waste streams unless an extension is approved by USEPA or the appropriate state regulatory agency. Due to the lack of available treatment and disposal facilities for waste that is both hazardous and radioactive, DOE facilities, including the Fernald site, are continuing to store this mixed waste. DOE has been pursuing a one-year case-bycase extension from USEPA to continue to allow storage after May 1992. The Federal Facilities Compliance Act (FFCAct) of October 1992 provides DOE with relief from enforcement under the LDR storage prohibition until October 1995, so long as the waste is stored in accordance with all other RCRA requirements. This time period may be extended further if DOE submits and obtains approval of a plan for providing the required treatment for LDR mixed waste. Such a plan must be 
approved before October 1995. The Fernald site has initiated the preparation of a Mixed Waste Treatment Technology Plan and is scheduled to submit an initial conceptual plan to OEPA in October 1993.

\section{RCRA Closures}

During 1992 and the first quarter of 1993, activities were underway to plan and implement the closure of Fernald site HWMUs. Many of these activities consist of proposing, obtaining approval, and implementing RCRA closures integrated with the CERCLA process under the Amended Consent Agreement with USEPA. RCRA closure activities during the January 1, 1992, through April 1, 1993, period are charted below:

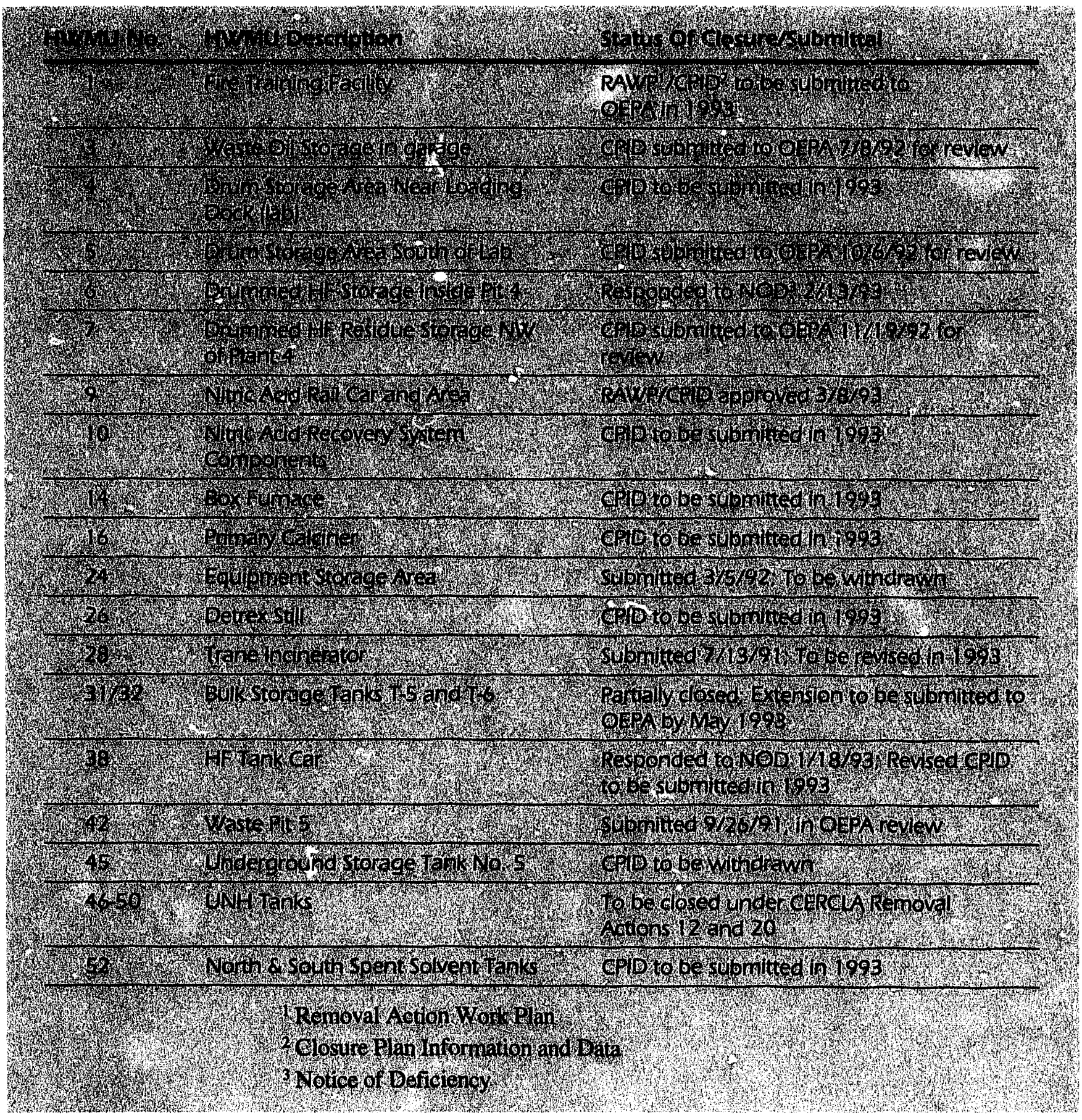




\section{Clean Air Act}

Clean Air Act activities for this period have included obtaining required permits for new facilities and maintaining permits required for existing equipment. Permits which serve unneeded or newly retired equipment are being cancelled. Support was also given to CERCLA projects, specifically through the identification of Applicable or Relevant and Appropriate Requirements (ARARs) such as emission limits, control equipment, or monitoring requirements which must be satisfied for these projects.

In order to improve the accuracy with which the Fernald site demonstrates compliance with the NESHAP standard for radionuclide air emissions, DOE has requested approval from USEPA to base the annual compliance demonstration on ambient air monitoring results, rather than on computer modelling of emission estimates. If approved, this method would improve the ability of the Fernald site to demons'rate that emissions from diffuse sources do not impact the offsite dose.

Due to the small magnitude of point source (stack or vent) emission sources which are still in operation at the Fernald site, there is only one source currently in operation with the potential for emissions above the level requiring continuous monitoring under the NESHAP regulations. Aithough the remaining sources are not required to be monitored continuously, they are required to be periodically monitored to verify their estimated emissions. A program is currently being developed and anticipated to be completed during 1993 to provide adequate confirmatory monitoring of all such sources.

\section{Radon Sources}

NESHAP regulations under 40 CFR 61, Subpart $Q$, specify a radon-222 flux standard of $20 \mathrm{pCi} / \mathrm{m}^{2}$ per second. In response to these regulations, a commitment has been made to USEPA that radon sources will achieve compliance with the flux standard upon final remediation under CERCLA. An additional commitment was to provide USEPA with estimates of radon-222 emissions from all sources which potentially have emissions in excess of the standard under the November 1991 Federal Facility Agreement (FFA) for Control and Abatement of Radon-222 Emissions.

The radon flux from waste pits 1, 2, 3 and 4 was measured and reported to USEPA during the January 1, 1992, through April 1, 1993, period. The results of these measurements show that the average level for each of the four pits was well below 20 $\mathrm{pCi} / \mathrm{m}^{2}$ per second. USEPA has agreed that, because hey are kept covered with water, the Clearwell and Pit 5 may be assumed to ha no radon emissions.

\section{Asbestos}

Test applications of various products were applied to transite panels at the Fernald site, in order to prevent the migration of asbestos fibers. An evaluation of these panels is continuing to determine the most effective and least-cost approach to solving this problem. 


\section{Toxic Substances Control Act}

In November 1991, USEPA issued a NON for storage of PCB containers in excess of one year. In response to this notice, the Fernald site outlined the status and disposal options for the 68 drums of PCBs and PCB items in its inventory as follows:

- Twenty-eight drums of PCB items were shipped to a commerial disposal facility in Texas in January 1992;

- Thirty drums were radioactively-mixed PCB liquids, and disposal at the Oak Ridge TSCA incinerator was proposed; and

- Ten drums were radioactively-mixed PCB solids, for which there are currently no disposal options.

Including eight drums generated since 1991, there are currently 48 drums of radioactive PCB waste stored at the Fernald site.

In February 1992, USEPA requested that the Fernald site report the status of the PCB wastes remaining onsite on a semi-annual basis. These semi-annual reports have been submitted in July 1992 and January 1993.

\section{Environment, Safety, and Health Assessments}

The concept of Environment, Safety, and Health (ES\&H) Assessments, also known as Tiger Team Assessments, was developed to evaluate compliance of all DOE facilities. To determine the actions taken in response to previous ES\&H Assessment findings, the Secretary of Energy ordered that small, focused Progress Assessments be performed. The ES\&H Assessment at the Fernald site was conducted from October 15 through October 25, 1991, and it was the pilot assessment for this new program. Key findings were cited representing potential compliance issues related to federal and state regulations or DOE Orders.

A draft Action Plan containing 57 response actions to these findings was submitted to DOE Headquarters in March 1992 for review. A revised action plan was submitted to DOE Headquarters for approval in March 1993.

An Environment, Safety, and Health and Quality Assurance functional appraisal of the Fernald site was conducted as a joint effort by FERMCO and DOE in November 1992. A final report outlining the findings of this appraisal will be issued during 1993.

An Environmental Management Assessment of the Fernald site was conducted by DOE Headquarters in March 1993. The assessment included a technical assessment in the quality assurance and radiation protection areas, as well as an overall management assessment of site operations. 


\section{Environmental Permits}

The following is a summary of the environmental permits applied for and received between January 1, 1992, and April 1, 1993.

\section{Air Permit Applications}

Under the Ohio Administrative Code, the Fernald site must obtain a Permit to Install (PTI) prior to the construction of an air pollutant source. The Fernald site is also required to obtain a Permit to Operate (PTO) for all operating air pollutant sources. During 1992, the Fernald site submitted four PTI and 42 PTO applications to OEPA. Additionally, 13 PTOs were cancelled due to the lack of plans for future operation of the sources. During the same time, two PTIs and 51 PTOs were approved by OEPA, and 126 PTOs were on hand by April 1, 1993.

\section{Water Permit Applications}

Two Wastewater PTIs and one Drinking Water System Plan Approval were received during 1992.

The effluent system is currently operating under the NPDES permit that was issued in February 1990 and modified in July 1991. A request for modification of the permit was submitted in July 1992. In response to new NPDES regulations concerning stormwater discharge (see page 48 of this chapter), a stormwater permit application was submitted to OEPA in September 1992.

\section{RCRA Permits}

A RCRA Part A Permit application for the Fernald site was first submitted in July 1984 and was subsequently revised several times. Under the PACD (now the SACD), the Fernald site submitted revisions to the RCRA Part A Permit Application in June 1991 and in October 1991. The RCRA Part B Permit Application was also submitted in October 1991. OEPA review comments were received in July 1992; a revised RCRA Part B Permit Application was submitted to OEPA in March 1993. 


\section{Air Pathway Monitoring}

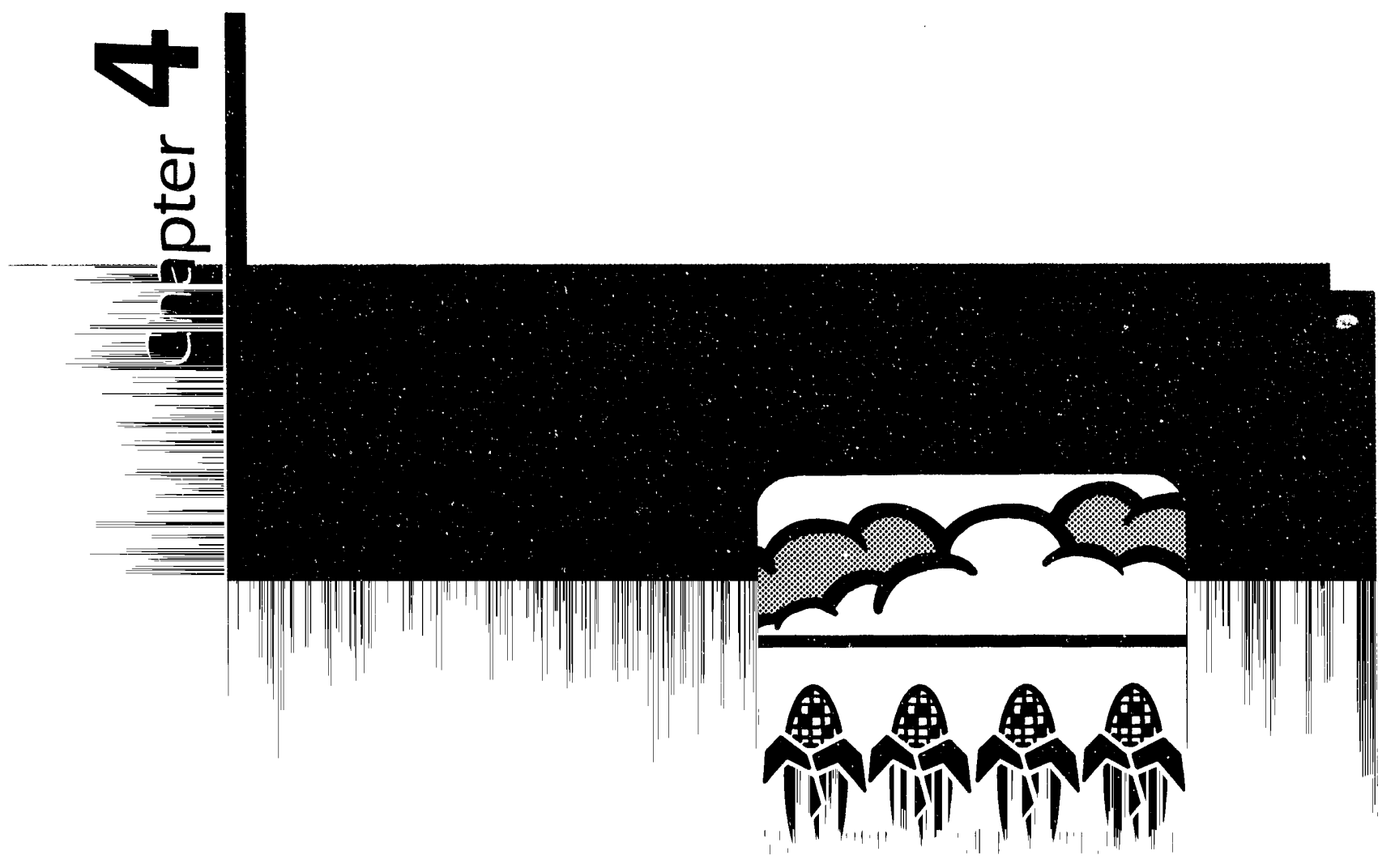




\section{Air Pathway Monitoring}

This chapter is the first of six that will focus on environmental monitoring at the Fernald site. It describes the air pathway and its components that may become contaminated as a result of the site's airborne emissions. As discussed in Chapter One, the public may be exposed to radiation from the site through the air pathway as a result of airborne emissions. This includes emissions from specific point sources (such as plant stacks), as well as dust from large, open areas, such as the waste pit area. When production operations were suspended in mid-1989, the majority of point source emissions from the site were eliminated. Since then, the largest sources of airborrie uranium emissions have

\section{FuGmve Dust}

The term fugitive dust is used to describe the small amounts of contaminated soil, waste materials, and construction dusts which are released from the fernald site as a result of the ongoing remediation work. Sources of fugitive dust at the Fernald site include dust generated as contaminated material is moved or repackaged, small amounts of soil carried away by the wind during the excavation of a trench, wind erosion of waste pit materials which are not covered by water, and soil erosion during dry, windy weather. been the cooling tower mists, which have low levels of uranium contamination, and fugitive dust from the waste pit area and locations where environmental cleanup activities are underway.

Air pathway monitoring focuses on the airborne pollutants that may be carried from the Fernald site as a particulate or gas and how these pollutants are distributed in the environment. Stack and building vent emissions are obvious sources of pollutants, but dust from construction and remediation activities, waste handling, and wind erosion are also important potential sources. The form and chemical makeup of pollutants influence how they are dispersed in the environment as well as how they may deliver radiation doses. For example, fine particles and gases are breathed in, while larger, heavier particles tend to settle and deposit on grass or soil. Chemical properties determine whether the pollutant will dissolve in water, be absorbed by plants and animals, or settle in sediments and soils. 


\section{Recults in Brief 1992 Air Pathway}

Ar - Data collected from fenceline air monitoring stations show that average concentrations of uranium were all less than $1 \%$ of the DOE standard. Airborne uranium emissions for 1992 were estimated to be $0.23 \mathrm{~kg}(0.51$ pound).

Soil - Some onsite and nearby offsite soil samples continue to indicate elevated uranium concentrations due to deposition of airborne particles from past opera tions. One offsite samping location, in the predominant wind direction north east of the site, had a total uranium concentration of $6.1 \mathrm{pCi} g$, which is above the background level of about 4.4 . pG/g for Ohio.?

Grass - The 1992 results indleate that uranium concentrations are higher at fenceline and onsite locations than at offsite locations. The elevated uranium con centrations in the soil where the grass samples were collected are believed to be the source of these higher concer trations.

Produce Uranium concentratons in produce were consistent with previous years data. Laboratony analysis did not detect any significant differences in urz nium concentrations between produce grown near the plant ahd produce grown at locations distant from the plant

Mik - In general, uranium concentrations from the local dairy are comparable to those from a background daily in Indiana. However, analysis of October samples showed a sudden increase in uranium concentrations at the local dairy. This in crease was not supported by analysis of other environmental media, and uranium concentrations returned to normal the remainder of the year.

Direct Radiation - Measurements of direct radiation indicate that levels increase with proximity to the $\mathrm{K}-65$ silos. These measurements are consistent with the fact that the silos contain radium and radon gas which contribute to the direct radiation in the vicinity. These levels are substantially lower than those measured in 1991 prior to the addition of the bentonite layer within the K-65 silos.

Boiler Plant - All emissions were well below permit limits. 


\section{Monitoring for Radioactive Pollutants}

During 1992, Fernald site personnel continued to monitor radioactive materials in the air pathway by sampling air, soil, grass, produce, and milk. This monitoring enables scientists to evaluate the effects of the cleanup efforts at the site, as well as fulfill the site's obligations toward ongoing environmental surveillance and dose estimating.

\section{Air Sampling for Radioactive Particulates}

The first step in monitoring the air pathway is measuring the emission rate of the pollutants at the point of release after they have gone through treatments and filtering. This is done by means of stack monitoring, and it provides preliminary information on how much pollutant is released and how it will behave in the environment. The second step in air pathway monitoring involves measuring the polluted concentration in ambient air onsite and at the site boundary. Since only a few stacks and vents continue to emit pollutants at the site, there are few data on site airborne emissions from stack monitoring. However, monitoring of site emissions continues through the use of air monitoring stations (AMS) located onsite, near the site fenceline, and at several locations in nearby communities.

Airborne pollutants are subject to existing weather conditions, thus wind speed and direction, rainfall, and temperature play a role in predicting how pollutants are distributed in the environment. Weather data, particularly wind speed and direction, provide input for selecting locations for the collection of environmental samples and locating monitoring stations.

During 1992, the site operated 16 air monitoring stations 24 hours a day, seven days a week as part of the Air Monitoring Program. Scientists selected the locations for the AMSs, as shown in Figure 21, for several reasons:

- AMS 1 through 7 provide data at the fenceline because this is where the public has closest access to the site and guidelines for offsite exposure apply;

- AMS 8 and 9 are in the prevailing wind direction at the site. They were added in 1986 to the northeast sector of the site based on a computer model that predicted where the highest ground-level concentrations of airborne uranium from plant operations would be found;

- AMS 10 through 14 are located at schools and industries near the site and provide additional monitoring of emissions at these points;

- AMS 15 and 16 were installed in 1989 to obtain additional background data AMS 15 is located near the University of Cincinnati, in Cincinnati, Ohio; AMS 16 is located in Miamitown, Ohio.

At each AMS, air is drawn through a $20 \mathrm{~cm}$ by $25 \mathrm{~cm}$ ( 8 in by 10 in) filter at a rate of about $1.3 \mathrm{~m}^{3} / \mathrm{min}$ (about $45 \mathrm{ft}^{3} / \mathrm{min}$ ). Technicians account for any changes in flow rate over the sampling period by inspecting charts that continuously record flow data. 
Figure 21: Air Monitoring Locations
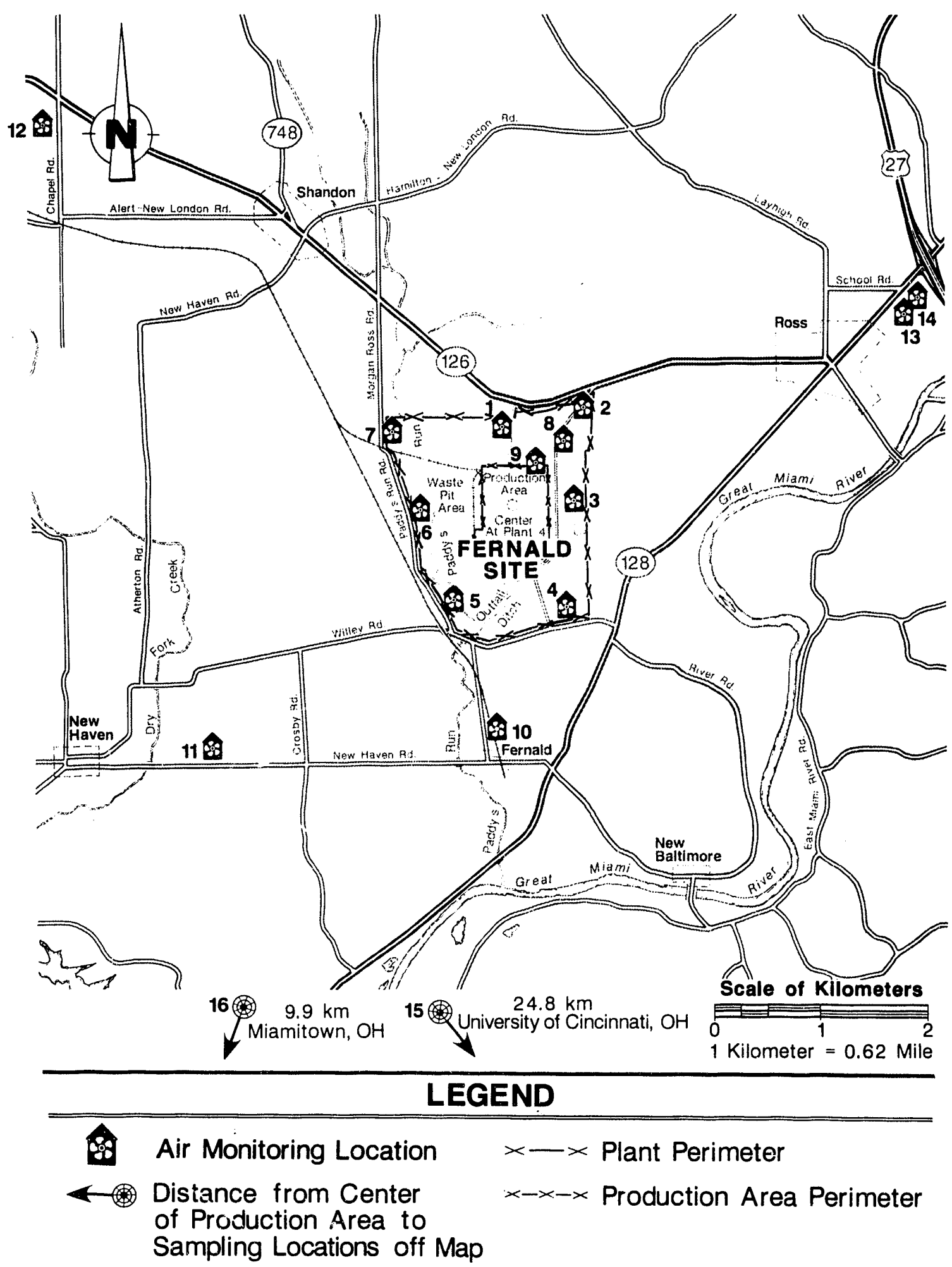
Environmental monitoring personnel collect the filters from the AMSs for analysis at weekly intervals. At the laboratory, technicians store the filters for at least three days following collection to allow naturally occurring, short-lived radionuclides (such as radon daughters) to decay. (This holding period does not affect the amount of uranium on the filters.) After the holding period, laboratory technicians heat the filters to $550^{\circ} \mathrm{C}\left(1,022^{\circ} \mathrm{F}\right)$ to remove organic matter. Finally, they dissolve these filters in acid and analyze the resulting solutions for uranium. A portion of each of these solutions is retained each week to prepare a yearly composite, which is then analyzed for trace concentrations of radionuclides such as isotopes of radium, neptunium, plutonium, and thorium.

DOE Order 5400.5, "Radiation Protection of the Public and the Environment," establishes guidelines for concentrations of radionuclides in air emissions. These concentrations, referred to as Derived Concentration Guidelines (DCGs), are concentrations of radionuclides that, under conditions of continuous exposure for one year by one exposure mode, would result in a dose of $100 \mathrm{mrem}$. The intent of the DCGs is to provide reference values that enable site personnel to review emissions data and determine if there is a potential to exceed the limits on dose to members of the public.

\section{METHOD USED TO DETERMINE A ARBORNE EMISSIONS}

The total ainborne uranium emissions are determined by summing the estimated and measured emissions from a number of stacks, vents, and processes onsite. Measured and estimated uranium emissions for 1992 totaled $0.23 \mathrm{~kg} 10.5 \mathrm{~J}$ pound. This represents a decrease of $20 \%$ from the 1991 estimated air emis sions. Uranium discharges from monitored stacks were the only measured emissions. Emissions from all other sources isted here were estimated. The decrease is consistent with trends in fernald site air emissions as restoration activities improve site conditions and decrease emissions to the environment Airborne emissions are expected to re nain at these low levels for several years, However, as fifal remediation of the site occurs, an increase in emissions is possible as contaminated buildings and equipment are torn down.

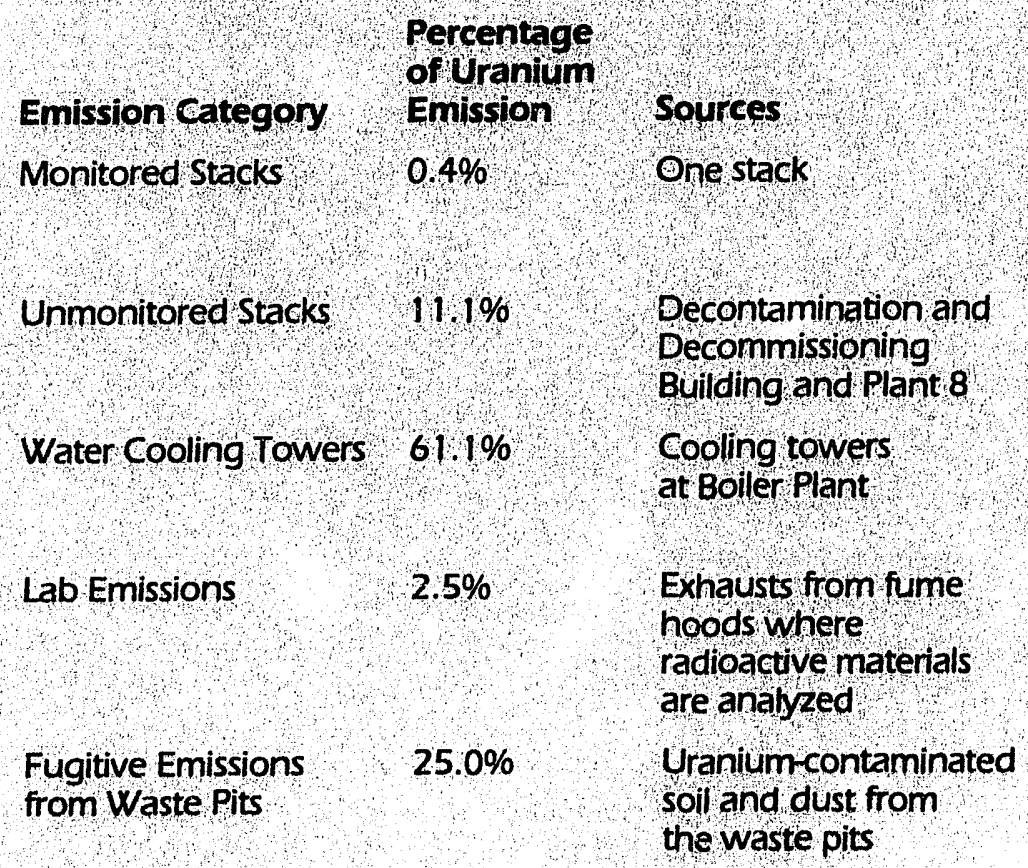

\section{Comments}

Decrease from 33 stacks in 1089 reflects end in production

Some estimated emissions were from the processing of wastes for shipment offsite

Estimated using uranium concentration of cooling water and loss as a mist

\section{Estimated based on 0.1 gram of uranium released per operating fume hood}

\section{Estimated according to approved USEPA method ${ }^{22}$}


The average concentrations of uranium at the seven fenceline AMSs (AMS 1 through 7) were all less than $1 \%$ of the DOE guideline. Table 3 on page A-4 lists 1992 data for uranium concentrations. Figure 22 compares uranium concentrations at the air monitoring stations for 1988 through 1992. The higher concentrations measured at AMS 9, located within the production area, are in part attributed to the emissions from the contaminated scrap metal pile which is located in the northeast corner of the production area.

The data on the concentrations of trace radionuclides in 1991 were not available for inclusion in the 1991 ASER, and they are presented in Table 4 on page A-5 with the 1992 concentrations. The results indicate that concentrations of trace radionuclides at the onsite and fenceline locations are well below DOE guidelines. Concentrations of thorium-232, measured at the AMSs, for 1988 through 1992 are presented in Figure 23. Thorium-232 is stored in quantity at several locations onsite and is considered a potential environmental contaminant.

Figure 22: Average Uranium Concentrations in Air, 1988 - 1992

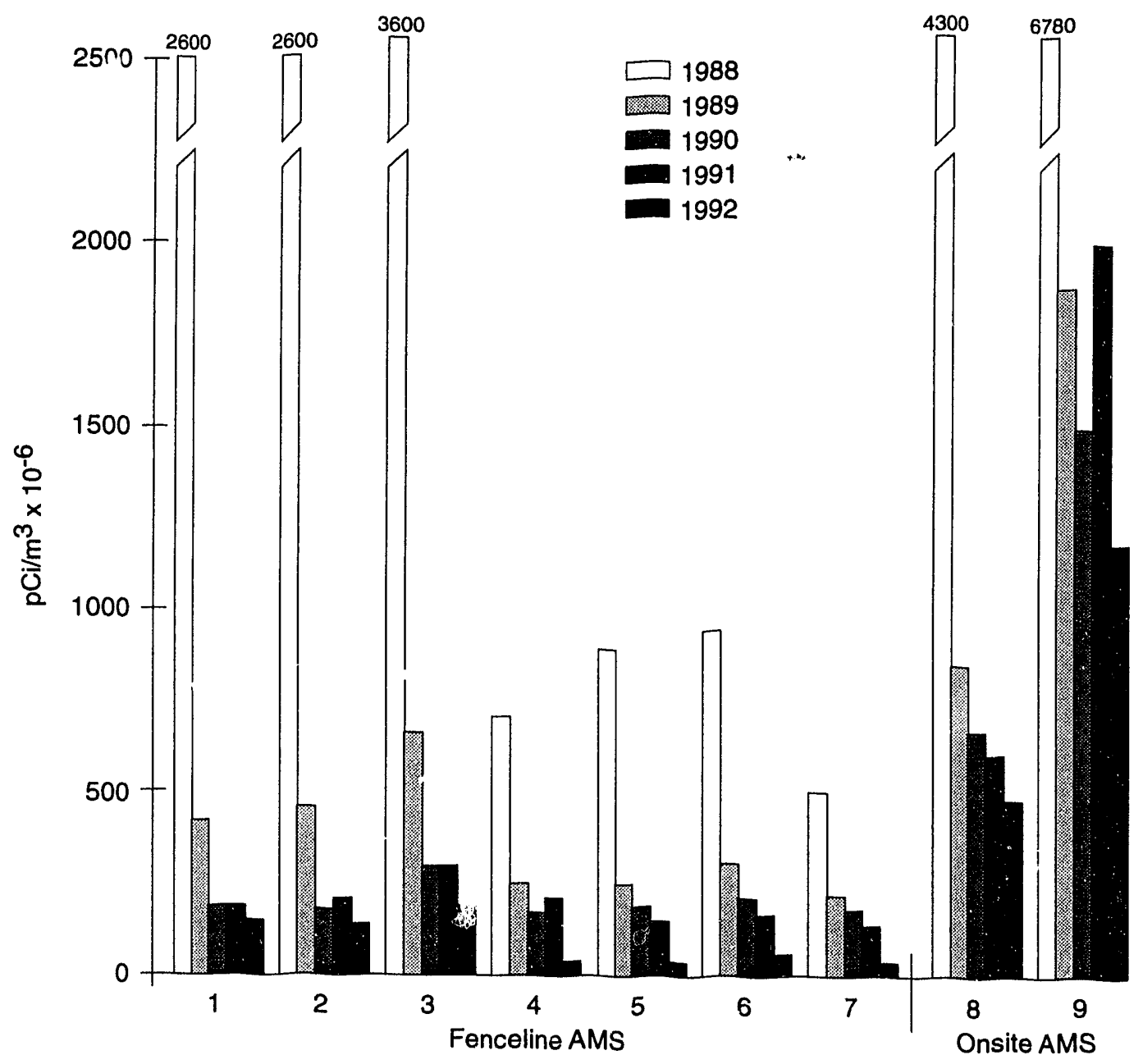


Figure 23: Average Thorium - 232 Concentrations in Air, 1988 - 1992

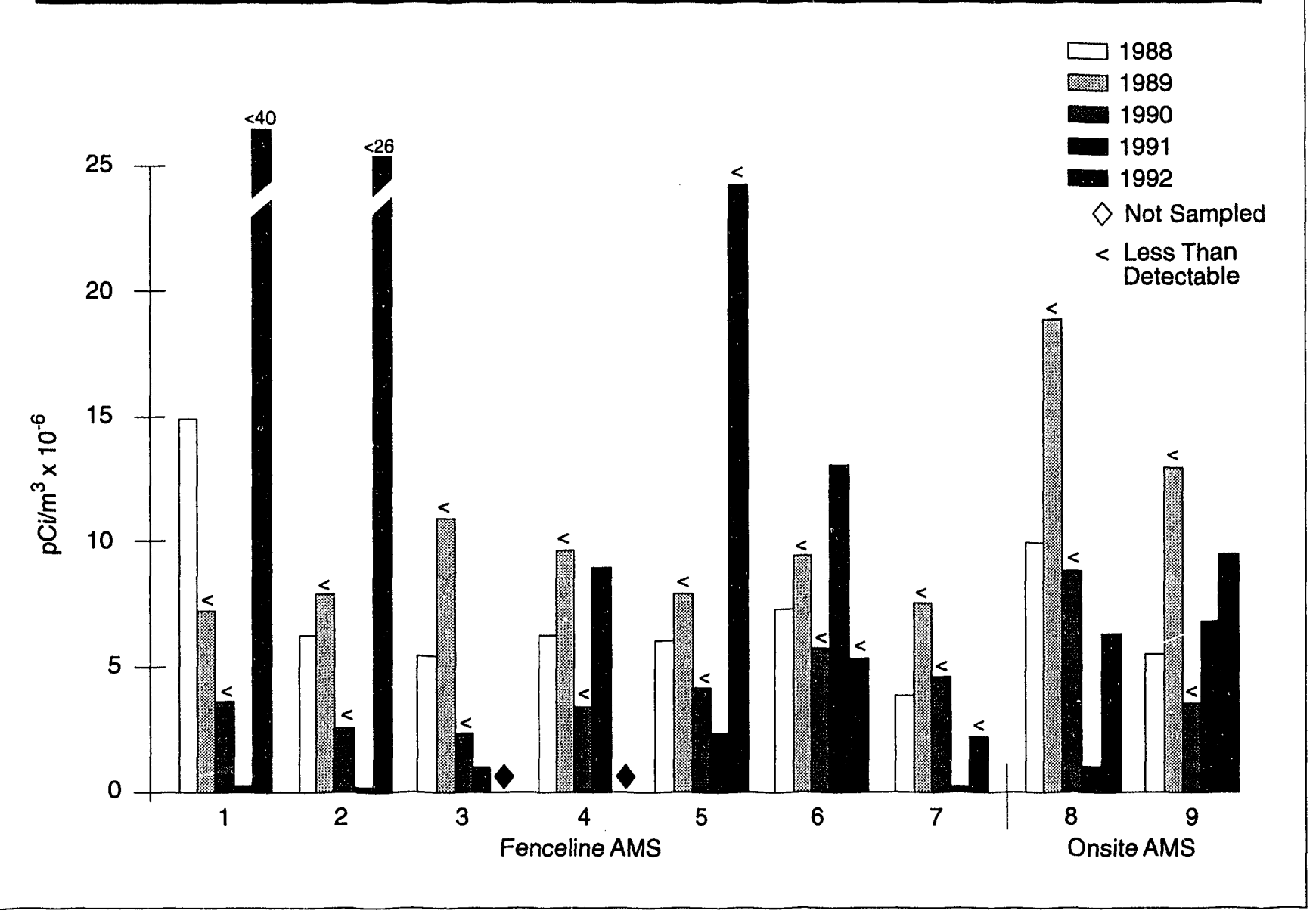

\section{Comparison of Measured and Estimated Emissions}

Scientists compared average air concentrations of uranium measured at the seven fenceline air monitoring locations to the predicted concentrations at the stations based on the emissions estimate of $0.23 \mathrm{~kg}(0.51$ pound $)$ of uranium. The comparison provides a means to evaluate the accuracy of the estimated emissions.

Results of the comparison are provided in Table 5 on page A-11. The results indicate that the measured concentrations are higher than the predicted concentrations. This finding suggests that the estimated emissions are higher than $0.23 \mathrm{~kg}(0.51$ pound). However, given the comparatively low emissions and limited accuracy of the model used to predict the concentrations, the predicted results are considered reasonably accurate. Currently, USEPA requires the site to use the estimated values in its calculations. 
Figure 24: Soil and Grass Sampling Locations

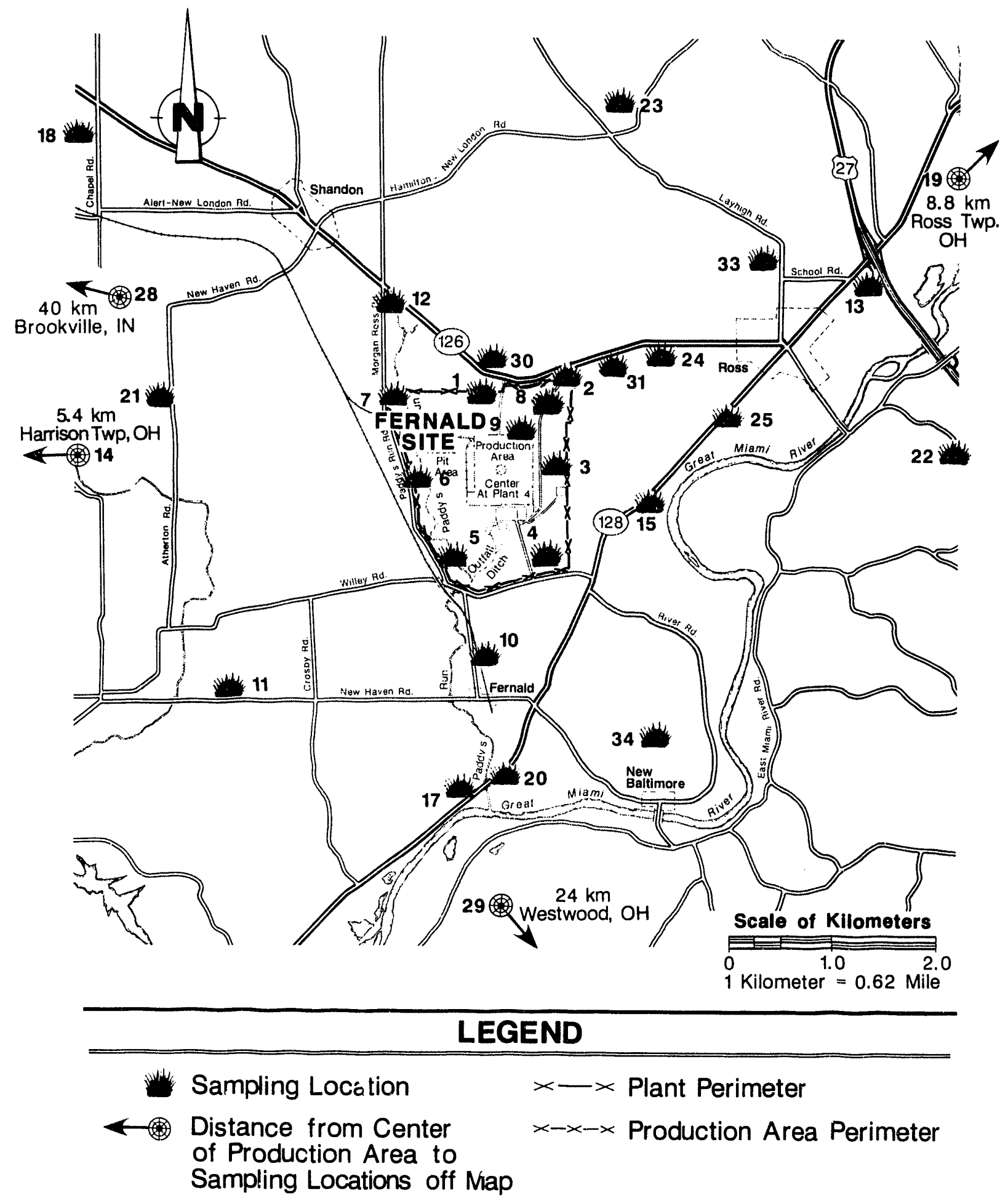




\section{Soil Sampling for Uranium}

Site technicians take annual soil samples at the air monitoring stations and offsite locations to determine if soil uranium concentrations in the area are changing (see Figure 24, previous page). Any uranium found in the soil may be naturally occurring, added by fertilizers, or a result of site operations. The amount of uranium naturally present in rocks and soils varies greatly (see Figure 25). For example, out of twelve samples collected throughout Ohio, the range of uranium-238 concentrations was $0.76 \mathrm{pCi} / \mathrm{g}$ to $2.2 \mathrm{pCi} / \mathrm{g} .{ }^{21}$ (The total radioactivity from uranium would be about twice this range because naturally occurring uranium in soil typically contains equal amounts of uranium-238 and uranium-234 radioactivity.) As a result, it is not possible to establish a single value for the background level of uranium and other minerals for an area such as near the Fernald site. While no DOE or USEPA guidelines or standards have been established for uranium in soil, both agencies have agreed that an acceptable level at which to begin cleanup activities for uranium in soil is $35 \mathrm{pCi} / \mathrm{g}$ or greater, based on potential dose..$^{23}$

To better evaluate the uranium concentration in soil, the site conducted a study to determine the amount of uranium naturaily present in soil near the site. Soil samples were analyzed for a number of radionuclides; however, only uranium results are reported here. Results from this study show that the mean uranium concentration is $2.1 \mathrm{pCi} / \mathrm{g}$ with an upper limit (95\% tolerance limit) of $2.8 \mathrm{pCi} / \mathrm{g}{ }^{24}$

Figure 25: Range of Total Uranium Occurring in Surface Soils

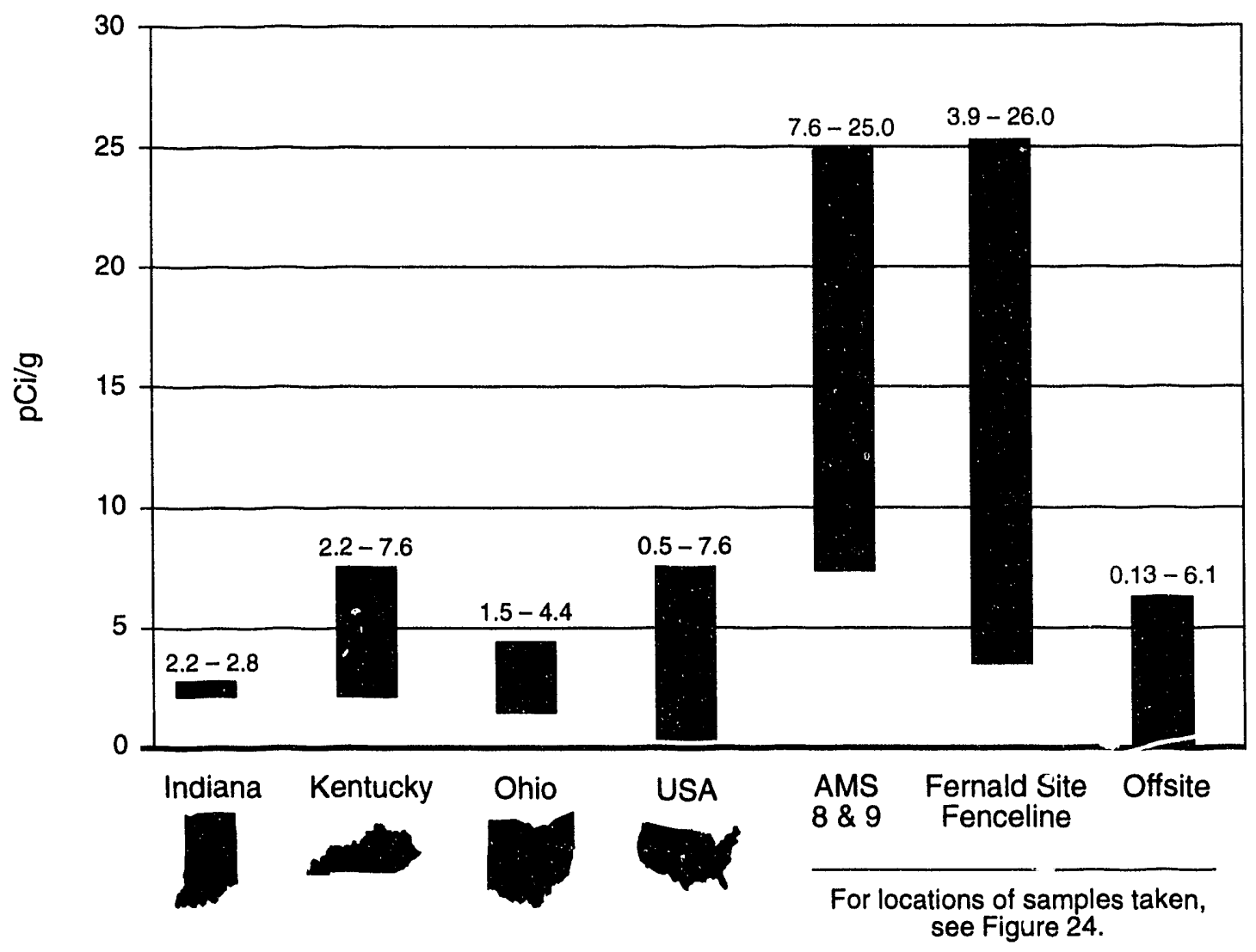


As part of the soil sampling program, technicians collect cores of soil from undisturbed plots at two depths, $0-5 \mathrm{~cm}(0-2$ inches) and 5-10 $\mathrm{cm}$ (2-4 inches), taking care to exclude grass frum the soil samples. Results from the $0-5 \mathrm{~cm}(0-2$ inches) depth show that uranium concentrations in the soil

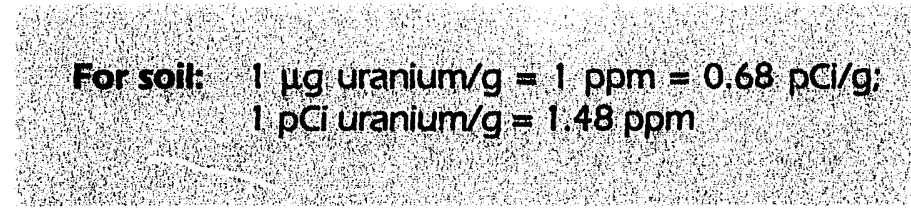
samples taken at two onsite locations ranged from 7.6 to $25 \mathrm{pCi} / \mathrm{g}$ dry weight, while samples collected along the fenceline ranged between 3.9 and $26 \mathrm{pCi} / \mathrm{g}$ dry weight at the $0-5 \mathrm{~cm}(0-2$ inches) depth (see Table 6 on page A-12). The higher concentrations in onsite soil are indicative of the soil contamination known to exist, particularly in the northeastern quadrant of the site. The uranium concentration in offsite samples ranged from $0.13 \mathrm{pCi} / \mathrm{g}$ dry weight at sample location 13 to $6.1 \mathrm{pCi} / \mathrm{g}$ at sample location 31, which is northeast of the site. Higher-than-background concentrations at sampling locations nurth and northeast of the site have been reported in past annual reports and are probably the product of airborne emissions and deposition during the period of uranium production. With the exception of the several locations north of the site, results from other offsite locations are within the range of naturally occurring uranium concentrations in Ohio soil.

\section{Grass Sampling for Uranium}

Uranium contamination in vegetation may result from transfer of uranium from the soil through absorption by the plant, deposition of eroded soil, or from uranium deposited on the surface of the plant from the air. As a general rule, uranium is not selectively absorbed by plants since it serves no useful purpose in the plants' metabolic processes; however, small amounts of uranium may be absorbed through a plants' normal growth processes. Fernald site personnel analyze grass for uranium to determine if airborne emissions are affecting the uranium concentration in grass.

Samples of grass were collected at the same locations as soil. Subsamples of grass are collected from the area around the soil sample location and then combined to form a composite sample. Each grass sample was a composite of at least three subsamples clipped near ground level. The composite samples each weighed about 500 grams (1 pound). An offsite laboratory air-dried and then analyzed the samples for uranium.

Standards have not been established for uranium in grass; however, comparing results of samples collected at the site with the results of samples collected offsite and distant from the site provides a means to evaluate the impact of site emissions on uranium concentrations in grass.

In addition to soil sample results, Table 6 on page A-12 reports the following uranium concentrations in onsite, fenceline, and offsite grass samples:

- Dnsite and fenceline results ranged from 0.01 to $0.46 \mathrm{pCi} / \mathrm{g}$ dry weight, and

- Offsite results ranged from 0.01 to $0.11 \mathrm{pCi} / \mathrm{g}$ dry weight. 
The results indicate that uranium concentrations are higher at onsite and fenceline locations. The elevated uranium concentrations in the soil where the grass sampies were collected are believed to be the source of these higher concentrations. There is no evidence from the AMS data to indicate that increased airborne deposition of uranium occurred.

\section{Produce Sampling for Uranium}

As mentioned in Chapter One, the Fernald site is surrounded by farmland.

Home-grown sweet corn and tomatoes are two of the major crops sold from roadside stands within three miles of the site. Local residents also grow and sell beets, potatoes, apples, lettuce, pumpkins, cucumbers, and peppers.

With air emissions reduced to very low levels, the possibility of uranium contamination in produce that is caused by air deposition is also very low. While washing the produce before eating removes any surface contamination which may be present, some uranium may be taken up by plants through their root systems and incorporated into their edible portions. Uranium detected in produce may be uranium that is naturally occurring in the soil, added by fertilizers, or deposited on the ground from airborne emissions.

Technicians sample produce each year to determine if uranium concentrations in produce grown near the site (0-5 km or 0-3 miles) are higher than concentrations in produce grown at distant locations (11-42 km or 7-26 miles) and are, therefore, a pathway of exposure from site emissions (see Figure 26 for sampling locations). The sample results are then used to estimate the potential dose to people from this component of the air pathway (see Chapter Seven).

The results of the produce and soil sampling program are reported in Table 7 on pages A-13 and A-14. In general, uranium concentrations varied greatly for each type of produce. A comparison between the uranium concentration in corn grown near the site with concentration in corn grown distant from the site determined that there is no statistical difference $(\mathrm{p}=.05)$ in the average concentrations of each group. ${ }^{25} \mathrm{~A}$ similar comparison using uranium concentrations in tomatoes found that the average concentration was actually higher in the tomatoes grown distant from the site. These comparisons suggest that there is no substantial impact today from past or current Fernald site emissions on produce grown in the area.

Technicians also sample the soil in which the produce is grown. This sampling is in addition to the soil sampling described earlier and is conducted to compare uranium concentrations found in soil with the concentrations found in produce. To date, no strong correlation between uranium concentrations in soil and produce has been established. Uranium concentrations in the soil taken along with preduce ranged from 0.8 to $3.1 \mathrm{pCi} / \mathrm{g}$ and were within the range of naturally occurring uranium concentrations in area soils. 


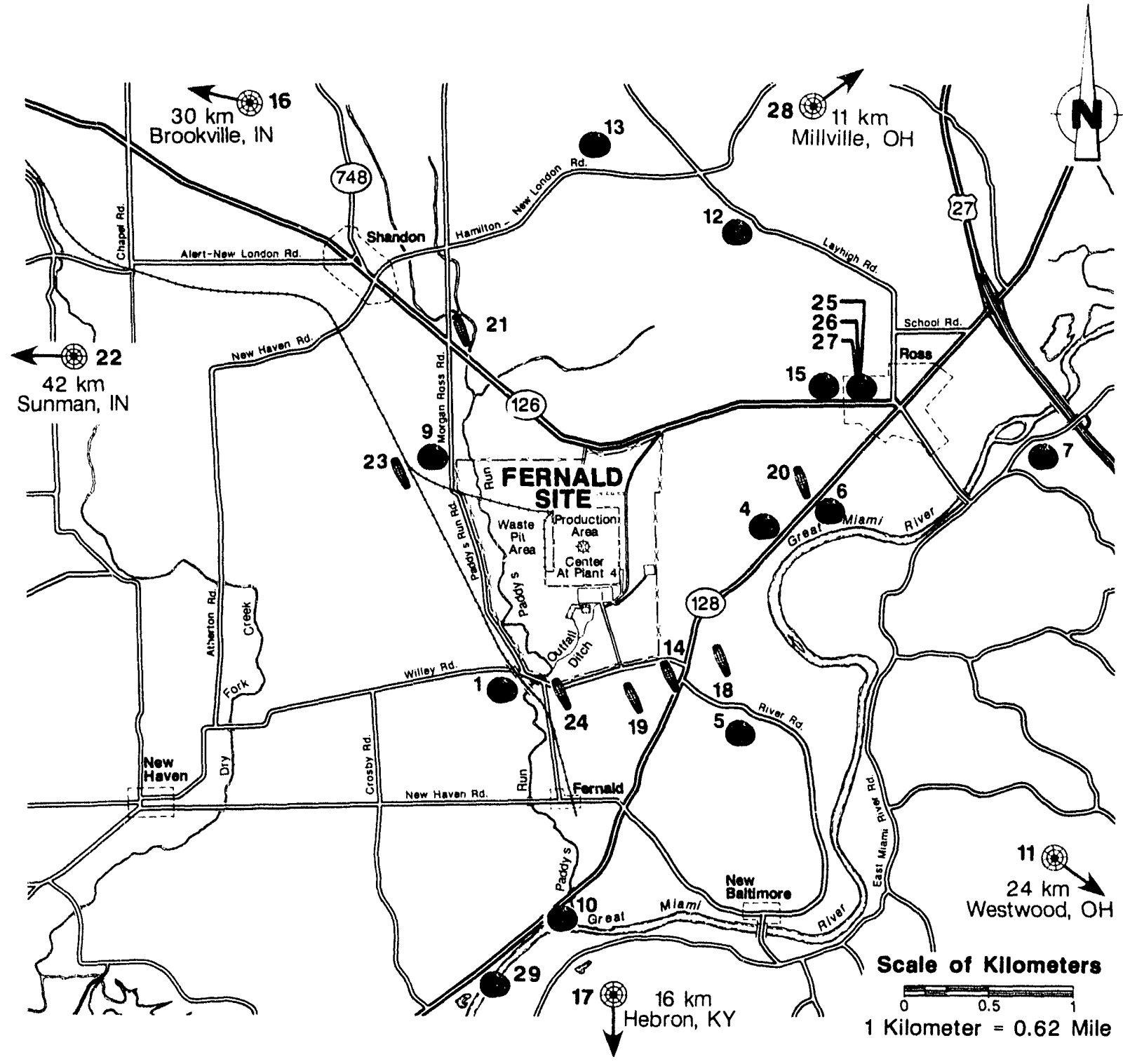

\section{LEGEND}

Sampling Locations:

Cash Crop

Garden Produce $\times \longrightarrow \times$ Plant Perimeter

$x-x-x$ Production Area Perimeter

$\leftarrow$ Distance from Center of Production Area to Sampling Locations off Map 


\section{Milk Sampling for Radionuclides}

Even though uranium is not normally concentrated in milk, the site monitors cows' milk as a component of the air pathway in response to public concerns about the dairy farm located next to the Fernald site. In 1992, technicians collected monthly samples of milk from the dairy adjacent to the site, as well as milk from a dairy in Indiana about $37 \mathrm{~km}$ ( 23 miles) west of the Fernald site. The milk samples were then frozen and shipped to an offsite laboratory for uranium analysis. In addition to monthly uranium analyses, once a year a set of milk samples is analyzed for radioactive materials present in trace concentrations (radium, thorium, etc.) in site emissions.

Table 8 on page A-15 presents the data from monthly milk sampling in 1992. In general, the results show uranium concentrations in milk from the local dairy were comparable to the uranium concentrations measured in milk from the background dairy in Indiana. However, the result of the October sample indicates a sudden increase in uranium concentration in milk from the local dairy. As part of the investigation into the high October result, a duplicate milk sample, collected at the same time as the original sample, was analyzed. The result of the duplicate sample also indicated a higher than expected uranium concentration in the milk $(13 \pm 2.3 \mathrm{pCi} / \mathrm{L})$.

The sudden increase is not supported by elevated air monitoring station results for the October period. Also, the well from which the dairy herd receives its water did not show a notable increase in uranium concentration at any time during 1992 (this well is sampled bi-weekly). Furthermore, uranium concentrations in milk from the local dairy returned to more typical values in November and December. Therefore, one can conclude that the increase in uranium concentration was not caused by releases from the Fernald site. The site takes a number of steps to ensure the integrity of all environmental samples; however, the possibility of sample contamination cannot be eliminated. The environmental monitoring program continues to work on improving the milk sampling and analysis program in order to improve the reliability of data.

Table 9 on page A-16 presents the results of the trace radionuclide analysis from milk. Results show that the concentrations of radionuclides in milk from the local dairy are similar to the concentrations in milk at the background dairy. The results also demonstrate that milk from the local dairy is not affected by site emissions. 
Figure 27: Direct Radiation Monitoring Locations

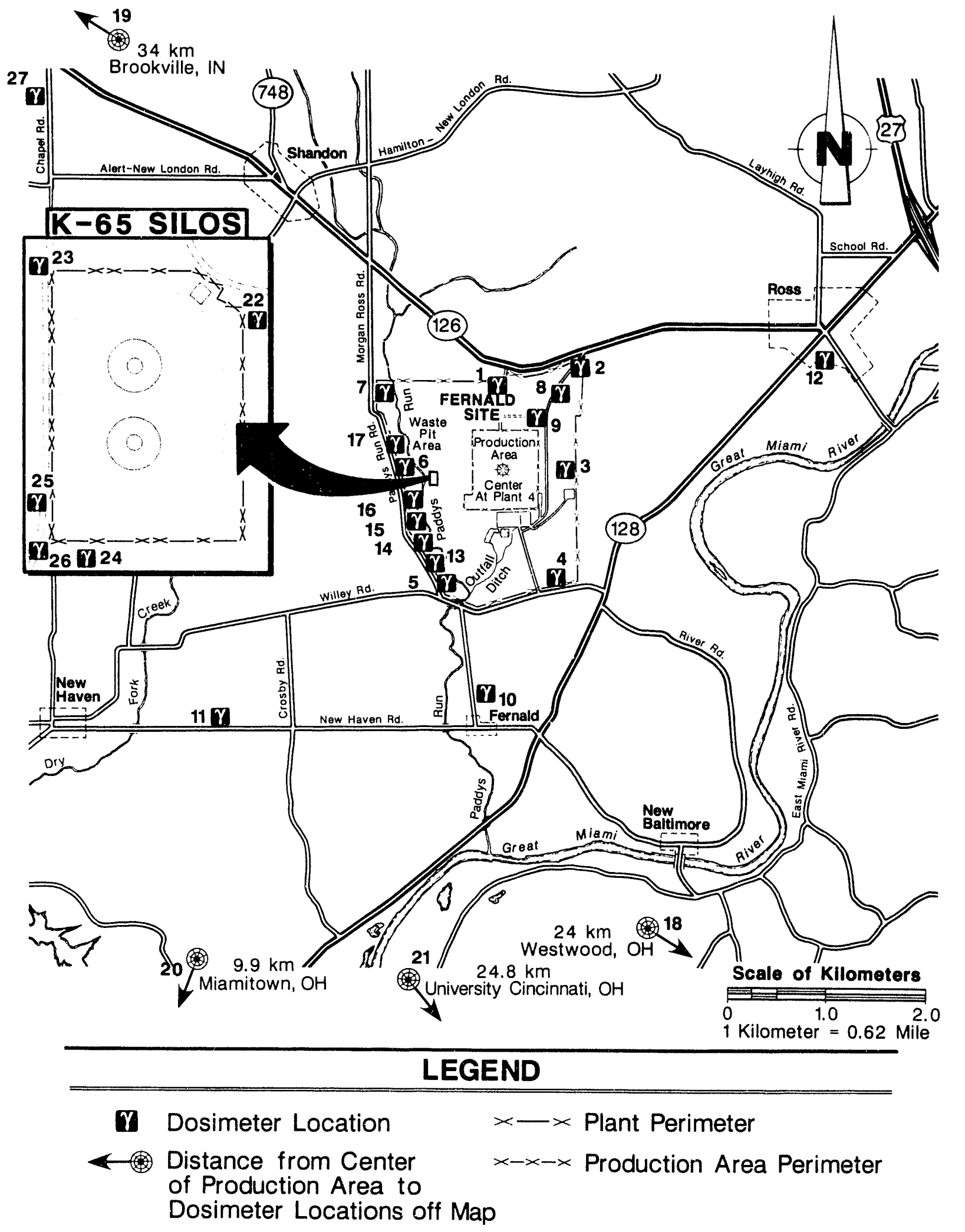




\section{Monitoring for Direct Radiation}

Direct radiation (X-rays, gamma rays, energetic beta particles, and neutrons) originates from sources such as cosmic radiation, naturally occurring radionuclides in soil, worldwide fallout, and radioactive materials at the Fernald site. The largest source of direct radiation at the site is the material stored in the K-65 silos. Gamma rays and $\mathrm{X}$-rays are the dominant types of radiation emitted from the silos. Energetic beta particles and neutrons are not a significant component of direct radiation at the Fernald site because uranium, thorium, and their decay products do not emit this radiation at levels that create a public exposure concern.

Direct radiation levels at and around the site are continuously measured at 32 locations with thermoluminescent dosimeters (TLD). TLDs absorb and store the energy of direct radiation within the thermoluminescent material. By heating the thermoluminescent material under controlled conditions, the stored energy is released, measured, and correlated to the amount of direct radiation. Figure 27 shows the location of the TLD monitoring points. These monitoring points were selected based on the need to monitor the K-65 silos, the site boundary, and several offsite locations, including background locations. The TLDs are placed at each monitoring location for a three-month period. A set of control TLDs is used to account for exposure accumulated during transport and any natural thermoluminescence. Starting in April 1992, three TLDs were placed at each monitoring location in order to comply with DOE recommendations and increase the precision of monitoring results.

Results of direct radiation measurements for 1991 and 1992 are provided in Table 10 on page A-17. Direct radiation fields vary from one location to another because of the differences in the terrestrial and cosmic components of natural background radiation. For example, varying concentrations of naturally occurring radium, thorium, and their decay products in soil result in different measured radiation levels. Measurements of direct radiation indicate that levels are higher in the area near the K-65 silos as expected. However, these levels are clearly lower than radiation levels measured in 1991 prior to the addition of the bentonite layer within the K-65 silos. An estimated dose from direct radiation is provided in Chapter Seven.

\section{Monitoring for Nonradioactive Pollutants}

OEPA requires an estimate of emissions from the Boiler Plant as par? of the site's effort to demonstrate compliance with the Clean Air Act. The site estimated the amount of nonradioactive pollutants including sulfur dioxide $\left(\mathrm{SO}_{2}\right)$, nitrogen oxides $\left(\mathrm{NO}_{\mathrm{x}}\right)$, and carbon monoxide $(\mathrm{CO})$ and measured the shade, or density, of particulate emissions from the coal-fired boilers. Shade, or density, is also called opacity and is a measure of how much light is blocked by particulates present in stack emissions. 
In order to estimate $\mathrm{SO}_{2}$ emissions, scientists regularly determine the sulfur content of the coal. Using this information and the total amount of coal burned, the amount of $\mathrm{SO}_{2}$ emissions can be calculated. For $1992, \mathrm{SO}_{2}$ emissions were calculated to be $74,000 \mathrm{~kg}$ (160,000 pounds). ${ }^{26}$ This was well below the allowable limit of 1.6 million $\mathrm{kg}$ (3.5 million pounds) calculated from information in the Permit to Operate issued by OEPA.

The $\mathrm{NO}_{\mathrm{x}}$ and $\mathrm{CO}$ emissions are estimated using USEPA-developed emission factors which utilize data on the combustion characteristics of the Boiler Plant and the gracie of coal burned. Nitrous oxide emissions for 1992 were estimated to be $68,030 \mathrm{~kg}$ (150,000 pounds). To date, the State of Ohio has not set $\mathrm{NO}_{\mathrm{x}}$ or $\mathrm{CG}$ limits for Fernald site industrial processes. Carbon monoxide emissions were estimated to be $24,000 \mathrm{~kg}(53,000$ pounds $)$ in 1992.

\section{Avr Emissions}

OEPA maintains an inventory system for actual air emissions from major point sources; the inventory is reported by the Department of Environmental Services Air Quality Management fformerly the Southwestern Ohio Air Pollution Control Agency). The totals presented here are in kilograms.

\begin{tabular}{lrrrrrr} 
& $\begin{array}{r}\text { Hamilton } \\
\text { County }\end{array}$ & $\begin{array}{r}\text { Butler } \\
\text { County } \\
1991\end{array}$ & $\begin{array}{r}\text { Combined } \\
\text { Counties }\end{array}$ & $\begin{array}{c}\text { Fernald Site } \\
\text { Boiler Plant }\end{array}$ \\
\hline Particulates & $3,000,000$ & $4,200,000$ & $7,200,000$ & 16,410 & 7,300 \\
\hline $\mathrm{SO}_{2}$ & $94,000,000$ & $8,800,000$ & $103,000,000$ & 408,800 & 74,000 \\
\hline $\mathrm{NO}_{X}$ & $29,000,000$ & $4,800,000$ & $34,000,000$ & 154,000 & 68,000 \\
\hline $\mathrm{CO}$ & $2,000,000$ & $20,000,000$ & $22,000,000$ & 55,000 & 24,000
\end{tabular}

Electrostatic precipitators reduce particulate emissions from the Boiler Plant. These emissions were estimated to be $7,300 \mathrm{~kg}(16,000$ pounds) for 1992 . This estimate was based on emission factors developed from stack testing in 1988. The opacity of the emissions

from the two site coal-fired boilers were continuously monitored by instruments designed for that purpose. During 1992, the boilers operated 4,965 hours, and 49,650 measurements were made and recorded at six-minute intervals. A total of eight excursions failed to meet the opacity standard. These excursions were brief, typically less than 18 minutes in length, and associated with boiler start up, wet coal, or the coal bunker fire in January.

In addition to directly affecting concentrations of contaminants in soil, grass, and other media discussed in this chapter. the air pathway can indirectly influence contaminant concentrations in the liquid pathway. Stormwater runoff is one way materials deposited in the air can be transported into surface water such as Paddys Run. Eventually, these contaminants may affect groundwater quality as well. The next two chapters describe the Fernald site's monitoring program for the liquid pathways, beginning with Effluent and Surface Water Monitoring in Chapter Five. 


\section{Liquid Pathway: \\ Effluent and Surface Water Monitoring}

ก

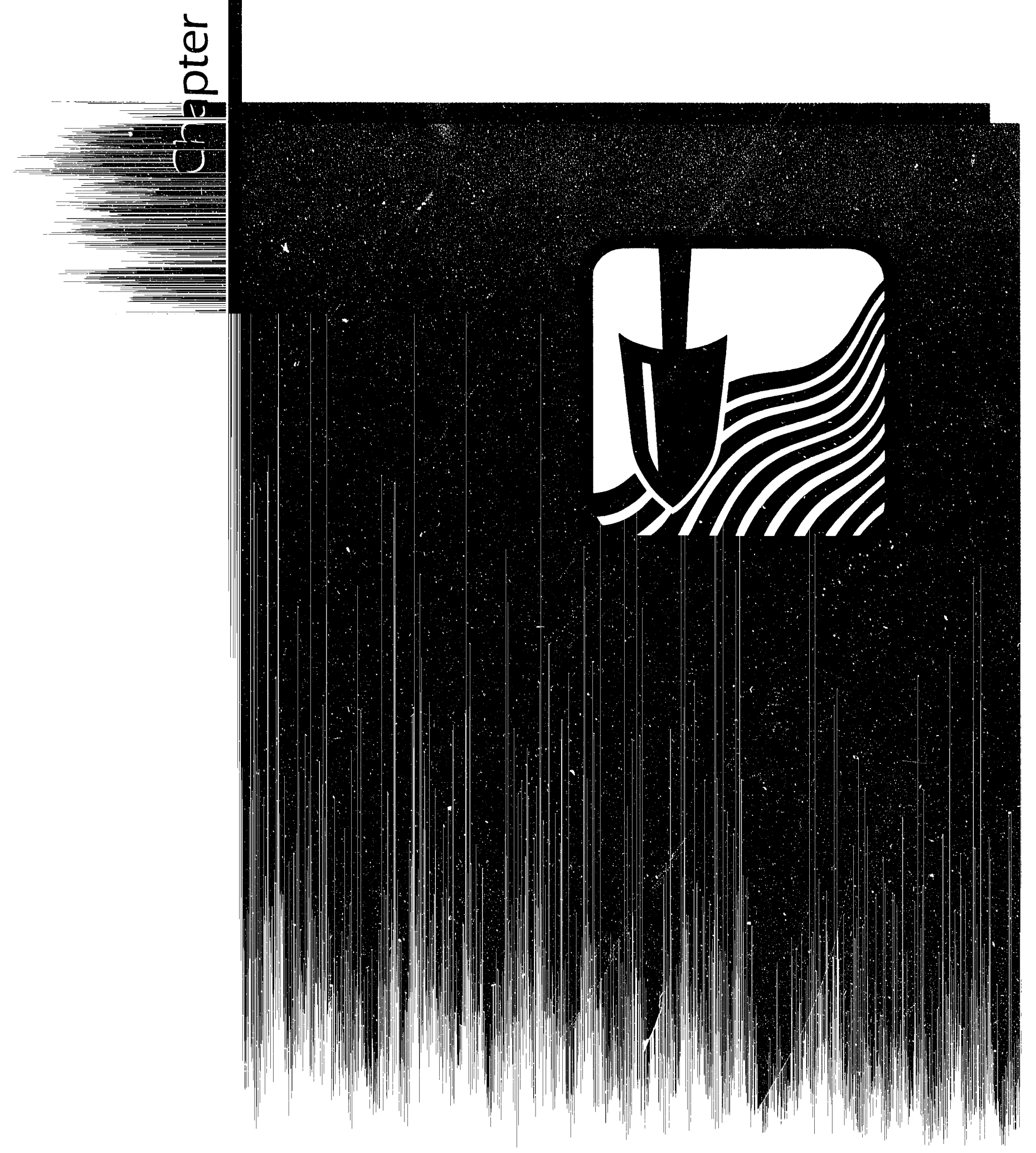




\section{Liquid Pathway: Effluent and Surface Water Monitoring}

The Fernald site investigates the effects of past and current operations on the second major pathway, the liquid pathway. Since contaminants can leave the site through the regulated liquid effluents and uncontrolled stormwater runoff, this chapter discusses sampling methodologies and results used to evaluate the site's effluents. It also discusses any impacts from the site on the Great Miami River and Paddys Run. Groundwater, another major component of the liquid pathway, is discussed in the next chapter.

\section{Results in Brief: 1992 Lquid Pathway, Effluent and Surface Water}

Effiuent - Approximately $436 \mathrm{~kg} / 961$ pounds/ of uranium were discharged to the Great Miami River during 1992 from Manhole-175; this was a reduction of over $30 \%$ as compared to 1991 . Approximately $159 \mathrm{~kg}(350$ pounds) of ura nium reached Paddys Run through uhcontrolled stormwater runoff during 1992.

Surface Water - The liquid effluent discharged to the Great Miami River resulted in a slight increase in downriver uranium concentration from the upriver loca tion. However, the downriver concentrations were consistent with 1991. Paddys Run continued to show effects of stormwater runoff from the site through higher uranium concentrations. Although the average uranium concentration at the nearest offsite sampling location was just slightly higher than in 1991, it was only $1.2 \%$ of the DOE guideline for drinking water.

Sediments - Radionuclide concentrations in the Great Miami River and Paddys Run sediments for 1992 were consistent with previous years' data and did not indicate a build-up of radioactive pollutants in the sediment.

Fish - Uranium concentrations in 1992 were no greater in fish caught downstream of the site's effluent line than in those caught upstream.

NPDES - During 1992 there were no *ividions of NPDES limits at Manhole-175, the monitoring point for site discharges to the river. Out of the yearly total of 6,190 NPDES samples taken, only 16 (all onsite) were not within permit limits.

Surface Water Quality - Concentrations of fluoride, nitrate-nitrogen, and pH values in the river showed little or no effect from fernald site operations, and all results were within acceptable limits. 


\section{Monitoring for Radioactive Pollutants}

The first section of this chapter centers on the radioactive pollutants and begins with an examination of the liquid effluent sampling and analysis program. A discussion of the river and creek surface water sampling program follows. The Fernald site conducts these programs because radionuclides in the regulated liquid effluent discharge and in uncontrolled stormwater runoff may be a source of radiation exposure to the public.

\section{Effluent Sampling for Radionuclides}

The site's liquid effluents have been categorized into twelve basic sources. All liquid effluents are monitored and, if necessary, treated before they leave the site. Figure 28 illustrates the flow of the effluents and where they are treated and monitored before they are discharged.

\section{Sources of Effluent During 1992}

The first two sources of liquid effluent are controlled contaminated stormwater runoffs from the waste pit area, which are collected and pumped to the Biodenitrification Surge Lagoon (BSL).

The third source of liquid effluent is perched groundwater, which is treated for volatile organic compounds (VOCs) and sent or to the Plant 8 Sump for further treatment. Following treatment at Plant 8 , the liquid is sent to the contaminated side of the General Sump, and the leftover solids are drummed and stored as a low-level radioactive waste.

The combination of plant effluent and pad stormwater is the fourth source of effluent, and it is sent directly to the contaminated side of the General Sump. All liquids from the contaminated side of the General Sump are combined and, if needed, are sent to the Plant 8 Sump where they are treated. If treatment is not required, they are sent on to the BSL.

At the BSL, runoff mixes with liquid from the contaminated side of the General Sump and the combined liquid effluent is treated in the Biodenitrification Facility (BDN) towers to reduce nitrates. From there, the liquid flows through the BDN effluent treatment system, after which the combined treated effluent flows to the Interim Advanced Waste Water Treatment (IAWWT) System (which is discussed further in Chapter Eleven), where uranium may be removed before it flows to Manhole-175 and on to the Great Miami River.

The fifth through the eighth sources of effluent are all collected in the noncontaminated side of the General Sump. Boiler plant blowdown and coal pile runoff are collected in the coal pile runoff basin and, after clarification, are sent to the 
Figure 28: Fernald Site Effluent Flow Diagram

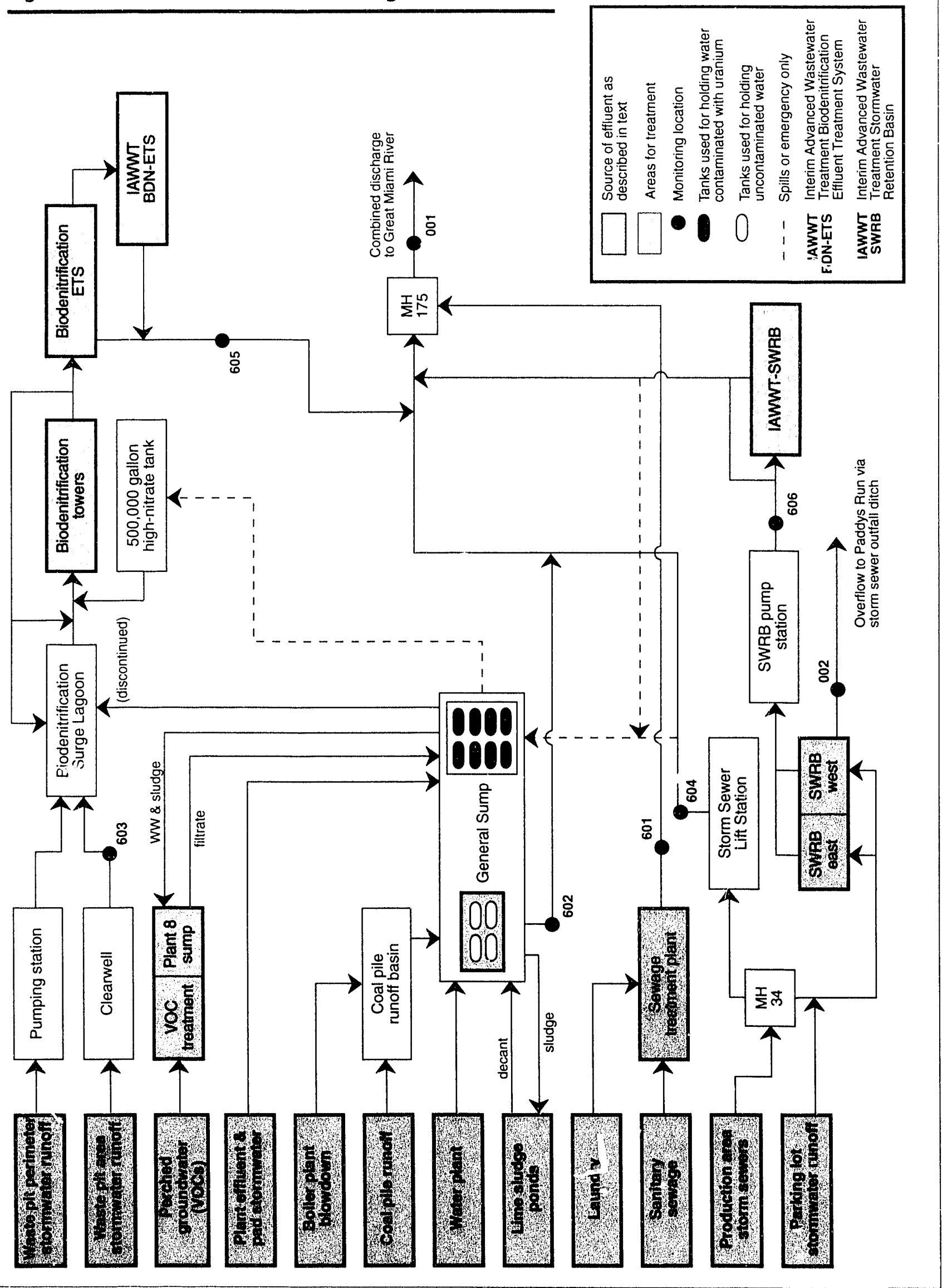


noncontaminated side of the General Sump. Water plant effluent and Lime Sludge Ponds decants are sent directly to the noncontaminated side of the General Sump. After settling, the liquids are then sent to Manhole-175, and the sludge is sent to the North Lime Sludge Pond.

The ninth and tenth sources of effluent are sanitary sewage and liquid from the laundry, which are processed at the Sewage Treatment Plant to remove biological contaminants. After treatment, the effluent is sent to Manhole-175 and on to the Great Miami River.

The eleventh and twelfth sources of effluent are produced from rain which has been collected by the production area storm sewers and parking lot runoff (see Figure 29). Stormwater runoff from the former production area is collected by a network of storm sewers that converge at Manhole-34. During dry weather, effluent is pumped to Manhole- 175 by the Storm Sewer Lift Station (SSLS). During storm situations, the SSLS is deactivated and all runoff is permitted to flow to the Storm Water Retention Basin (SWRB). Here it mixes with runoff from the parking lot storm sewers and is allowed to settle. From the SWRB, the effluent is treated at the IAWWT before it is eventually pumped to Manhole-175 and on to the Great Miami River.

In summary, the Fernald site controls liquid effluents and treats them as necessary before they eventually enter Manhole-175. There, the effluents combine to form a single liquid from which a representative sample can be taken before the effluent flows to the Great Miami River.

During 1992, on an average day, 6.9 billion liters (1.8 billion gallons) of Great Miami River water flowed past the site's effluent line. ${ }^{7}$ The site discharged an average of 2.2 million liters (580,000 gallons) of effluent into the river each day. Therefore, on average, each liter ( 0.26 gallon) of effluent discharged was combined with about 3,100 liters ( 820 gallons) of river water.

\section{Sampling Methodologies}

The mixed effluent, described above, was sampled at Manhole- 175 by a flow-proportional sampler, a continuously operating device that collects a varying amount of the effluent in proportion to the volume of effluent flow. After every 24 hours of operation, the collected liquid is removed from the automatic sampler to provide a daily flow-weighted sample of the effluent (see Figure 30 on page 84).

Scientists analyzed a portion of each daily sample of effluent flowing through Manhole-175 to determine the amount of total uranium discharged to the Great Miami River. In addition, they mixed portions of all daily samples collected during each month to form either monthly composites or three-month composites. The monthly composites were analyzed for the four uranium isotopes and 15 other radionuclides listed in Table 11 on page A-18. Composites, rather than daily 


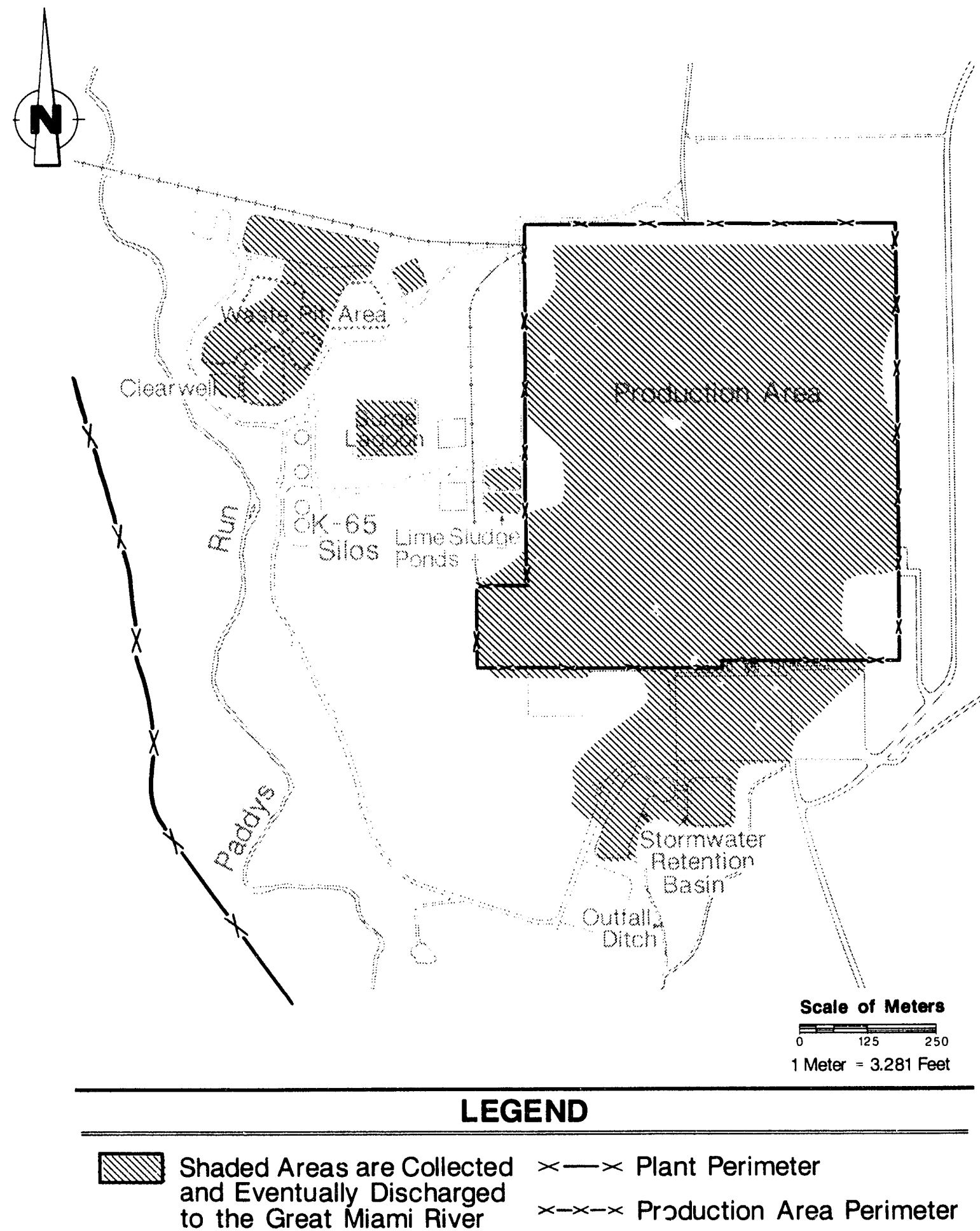


Figure 30: Continuous Sampling at Outfall 001

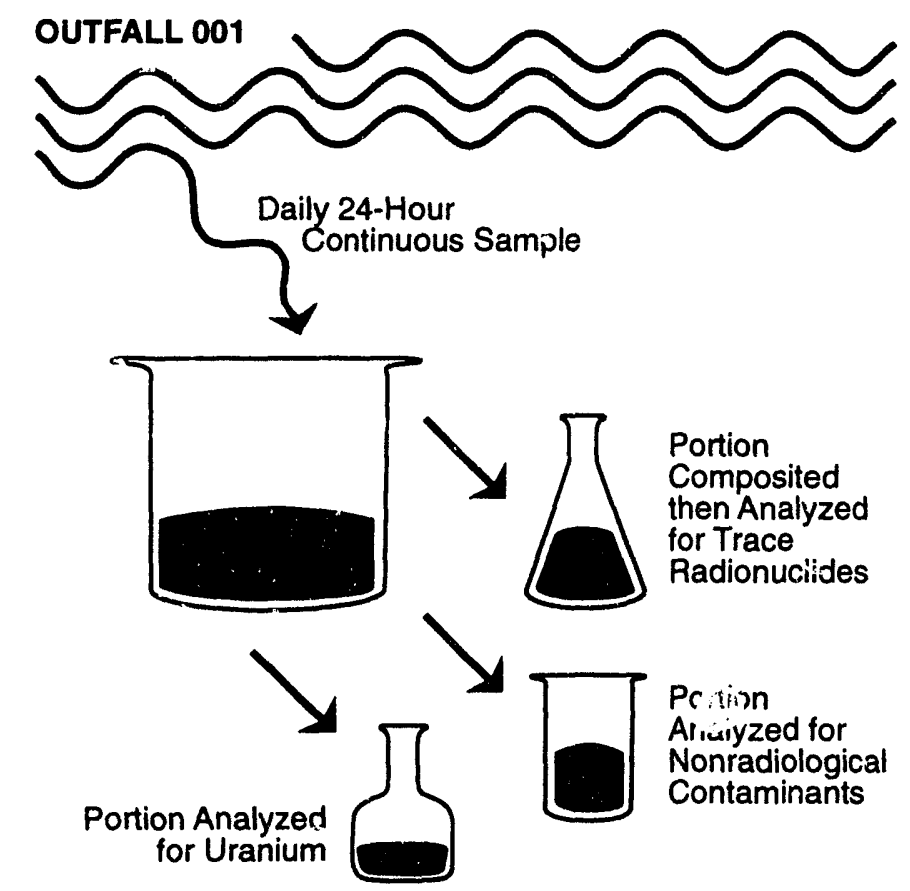

samples, were analyzed because many of the radionuclides have been present in only trace amounts, and it is neither practical nor cost-effective to perform more frequent analyses for them. The three-month composites were analyzed for cesium-137, ruthenium-106, and strontium-90.

The Fernald site also monitors any discharges to Paddys Run that occur from the overflow of the SWRB. Since the SWRB began operating in 1986, the amount of uranium entering the outfall ditch has been substantially reduced. During 1992, the SWRB did not overflow.

\section{Results of Laboratory Analyses}

Table 11 on page A-18 is a summary of the radionuclide analysis of the liquid effluent discharged to the Great Miami River. The table shows the total Curies discharged during 1992 compared to 1991 and the average concentration (in $\mathrm{pCi} / \mathrm{L}$ ) of each radionuclide in 1992. Not all data had been received in time to be included in this report, but they will be made available in the 1993 report.

The average concentration of each radionuclide is compared to the Derived Concentration Guideline (DCG) or standard. DOE orders state that a dose must be estimated based on all of the radionuclides present in the effluent. The annual average percentages of the DCG for each radionuclide, when added together, must not exceed $100 \%$. When the total is above $100 \%$, the site is required to use the "best available technology" to reduce radionuclide concentrations in its effluent.

An Advanced Wastewater Treatment (AWWT) Facility is presently under construction to provide "best available technology" treatment of both stormwater and process wastewater before their discharge to the Great Miami River. An interim facility, using similar technology, was placed into operation at the SWRB in July 1992. Another interim system is expected to begin operation in 1993 to extract uranium from wastewater discharged from the BSL. 
During 1992, 0.29 Curie ( $436 \mathrm{~kg}$ or 961 pounds) of uranium was discharged to the Great Miami River through Manhole-175. This was a decrease of $28 \%$ on an activity basis and $34 \%$ on a mass basis, in comparison to the 0.40 Curie $(663 \mathrm{~kg}$ or 1,489 pounds) of uranium discharged to the river during 1991. Comparisons of uranium discharges at Manhole-175 during 1992 and the four previous years are shown in Figure 31 (in Curies and kilograms).

The Fernald site reports an estimate of uranium in uncontrolled stormwater runoff into Paddys Run to the USEPA. Based on a series of grab samples collected in various onsite drainage ditches that flow into Paddys Run, Fernald site personnel had developed a general estimate of $4.5 \mathrm{~kg}$ (10 pounds) of uranium in the runoff to Paddys Run for every inch of rain. In November 1992, this estimate was reduced to $2.8 \mathrm{~kg}$ (6.3 pounds). This change was brought about to reflect the completion of the Waste Pit Area Runoff Control Removal Action that now directs contaminated runoff from the waste pit areas to the BSL and has eliminated that source of contamination to Paddys Run. For 1992, the estimate of uranium in stormwater runoff to Paddys Run was reported as $159 \mathrm{~kg}$ ( 350 pounds). This estimate was based on the amount of precipitation recorded at the Greater Cincinnati - Northern Kentucky International Airport rather than data from the site due to a computer software error at the site.

Figure 31: Total Uranium Discharged through Outfall 001, r 988 - 1992
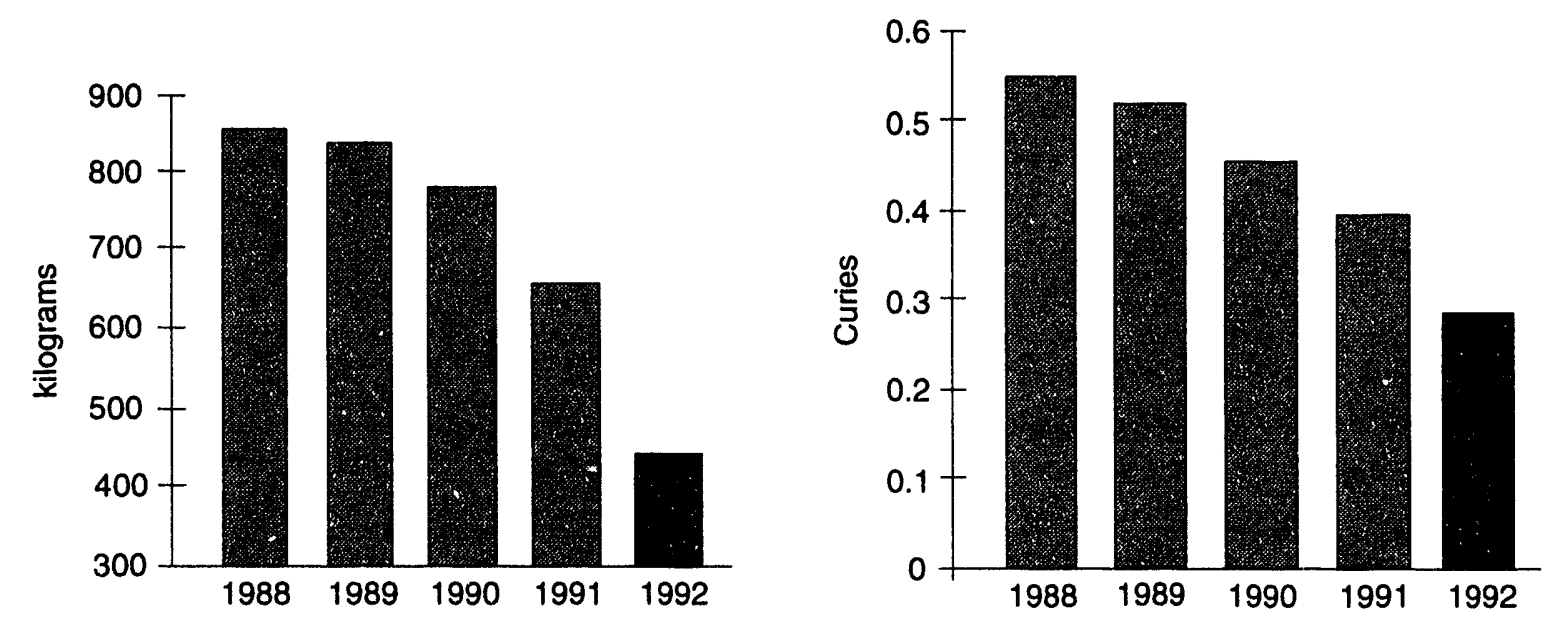


\section{Surface Water Sampling for Radionuclides}

The site's surface water sampling measures the effects of two sources of contamination: the discharge of liquid effluents into the Great Miami River and the effects of uncontrolled stormwater runoff into Paddys Run and overflow from the SWRB (which did not occur in 1992). Figure 29 shows the area of controlled stormwater runoff.

\section{Sampling Methodologies}

During 1992, surface water was sampled at the following locations identified in Figure 32:

- Three locations along the Great Miami River (W1 - upstream from the effluent discharge, W3, and W4);

- Five onsite locations along Paddys Run (W9, W10-US, W10, W10-DS, and W11);

- One location along the drainage ditch originating near the Pilot Plant (W10-DD); and

- Three offsite locations along Paddys Run (W5 - upstream from the site, W7, and W8).

Each week, the onsite laboratory analyzed one of the daily samples from each river sampling location for total uranium. Portions of the daily samples collected along the Great Miami River were combined to form weekly and monthly composites for each location, which were then analyzed for radium-226 and radium-228. Six-month composites, taken from the individual monthly composites, were analyzed for cesium-137, strontium-90, and technetium-99.

Weekly grab samples were collected at the five onsite locations along Paddys Run and one location along the drainage ditch and analyzed for total uranium. Often times there is not enough water present to collect a sample. Uranium concentrations at W10 have varied greatly. Uranium concentrations in surface water are not directly comparable over time due to different states of dilution as a result of varying precipitation and flow rates. Consequently, representative samples cannot always be obtained because the effluent from the drainage ditch often does not have sufficient time to completely mix with the water in Paddys Run to provide a homogeneous mixture for sampling. In order to account for this problem, three sampling locations (W10-US - just upstream of W10 - near the K-65 silos, W10-DD - along the drainage ditch, and W10-DS - just downstream of W10) were sampled.

\section{Results of Laboratory Analyses}

The radionuclide concentrations found in surface water samples collected during 1992 are summarized in Table 12 on pages A-19 and A-20. The data indicate that uranium concentrations in the Great Miami River were significantly higher downstream of the site's effluent discharge (W3 and W4) than they were upstream (W1). ${ }^{27}$ However, average uranium concentrations at $\mathrm{W} 3(1.2 \mathrm{pCi} / \mathrm{L})$ and $\mathrm{W} 4(1.3 \mathrm{pCi} / \mathrm{L})$ 
Figure 32: Surface Water Sampling Locations
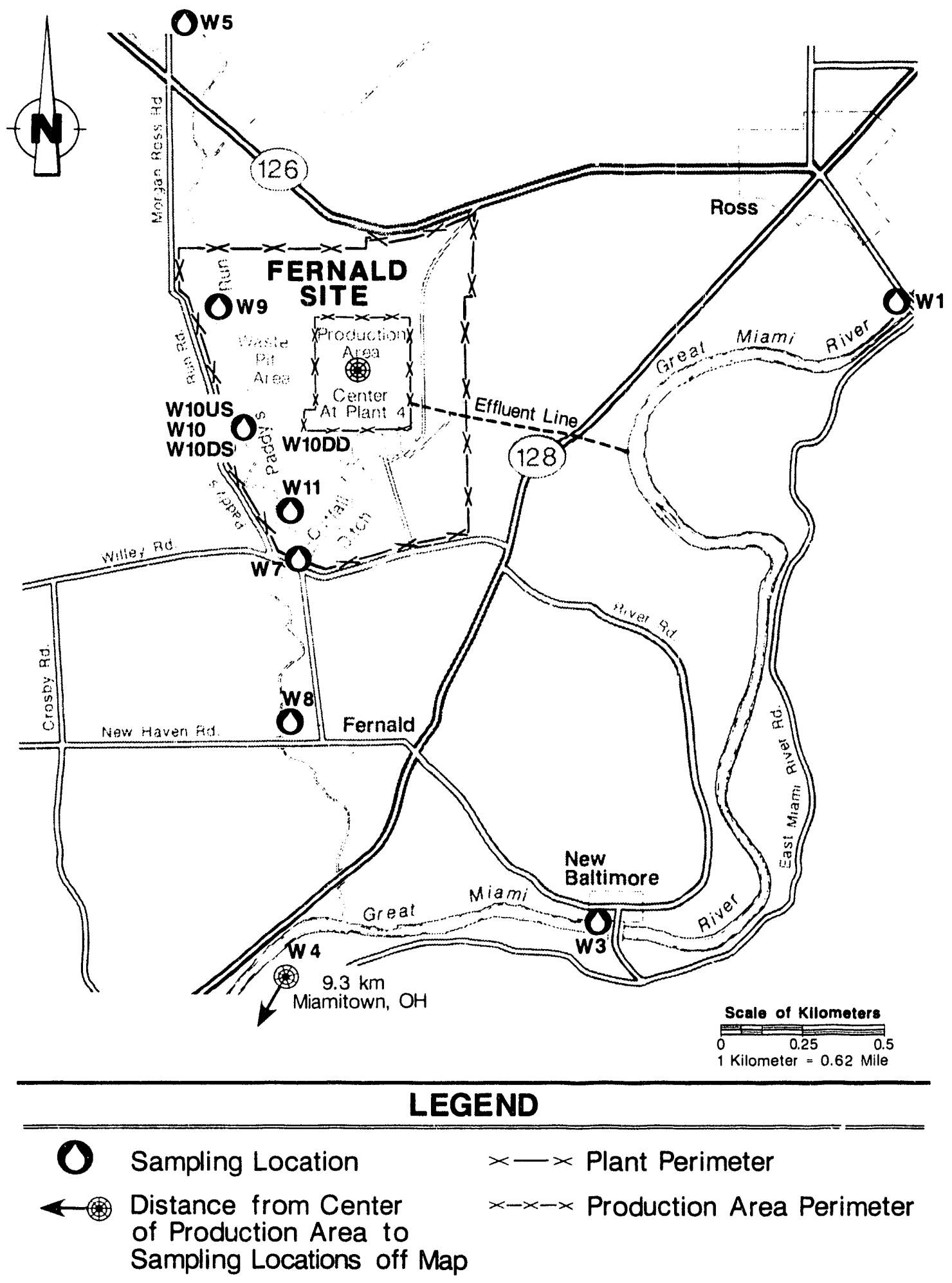
were well below the DOE guideline for drinking water (used for comparison purposes only) both at $0.23 \%$ of the DCG. Figure 33 shows five-year trends of uranium concentrations in surface water from the Great Miami River and Paddys Run.

Surface water samples collected from the Great Miami River in 1992 showed no measurable increases resulting from the site's effluents in the concentrations of radium-226, radium-228, strontium-90, cesium-137, and technetium-99. These data support the results in Table 6, demonstrating that the concentrations of these radionuclides in the liquid effluent discharged to the river were very low and would result in very little, if any, increase in the concentrations already present in the river.

Figure 33: Average Uranium Concentrations in Surface Water, 1988 - 1992

Great Miami River Locations

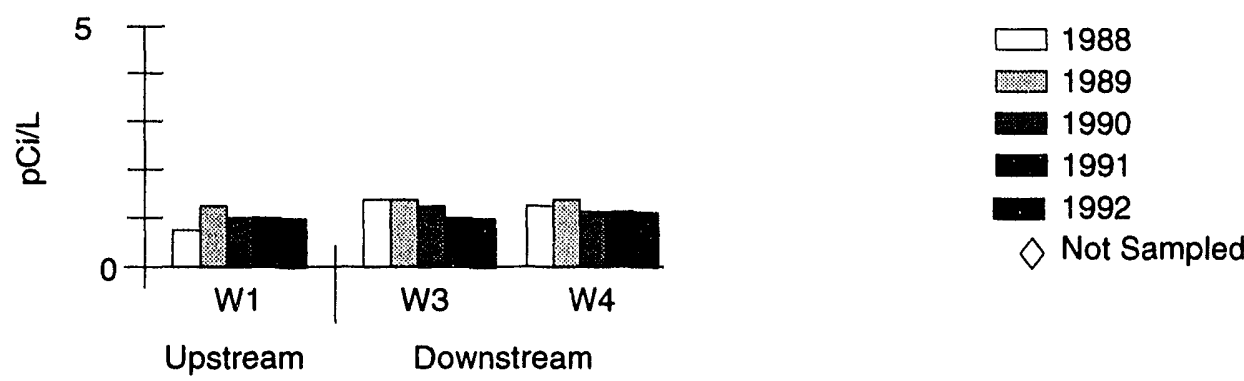

Paddys Run Locations

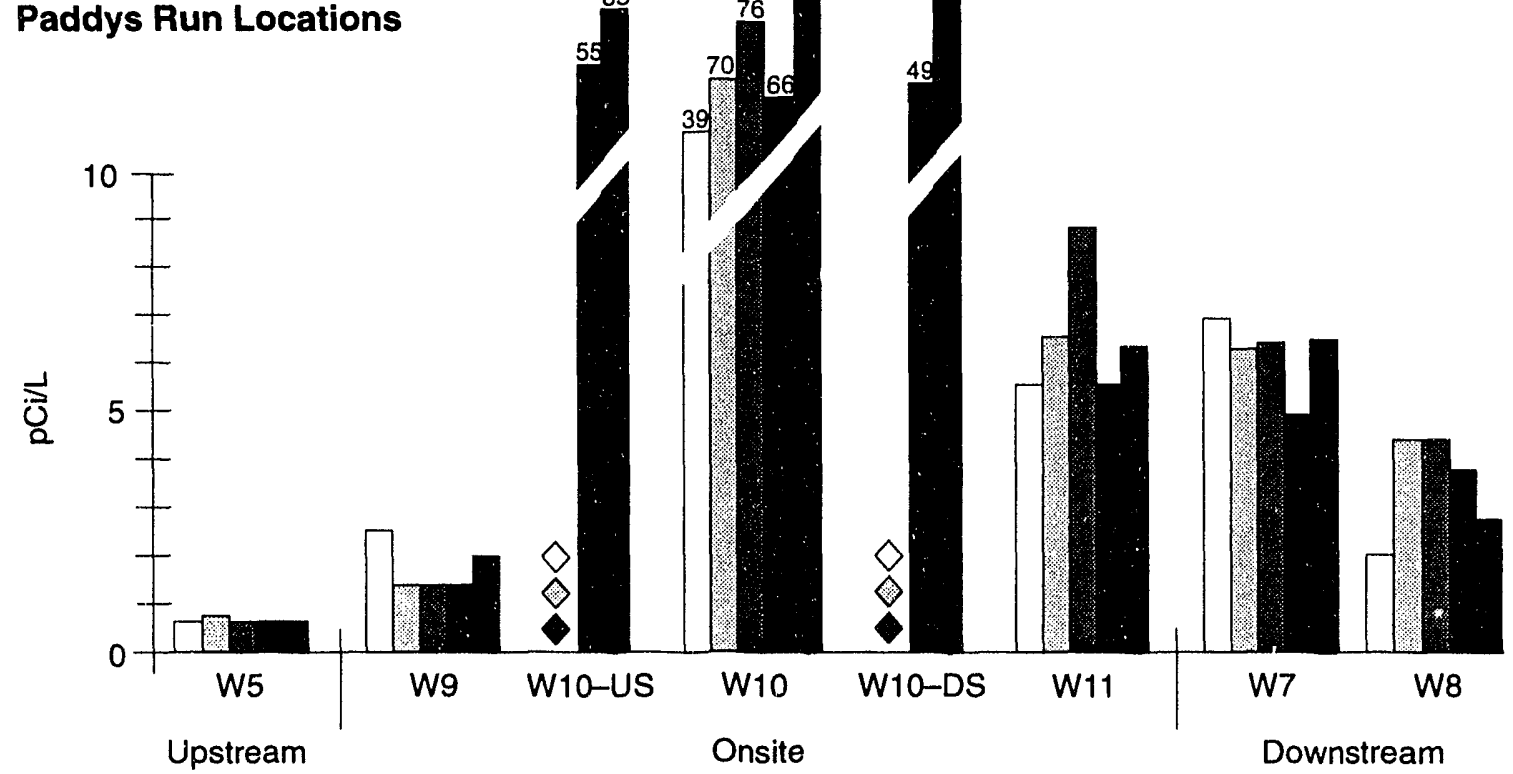


Fernald site personnel also analyzed surface water samples collected from Paddys Run. Environmental monitoring personnel used upstream sampling point W5 to determine concentrations of uranium and radium normally present in this stream. The data indicate that the uranium concentrations found in Paddys Run were significantly higher downstream (W7 and W8) of the site than they were upstream (W5). ${ }^{27}$ However, average uranium concentrations at all Paddys Run monitoring locations were well within DOE guidelines for drinking water (used for comparison purposes only), ranging from $0.36 \%$ of the DCG at W9 to $17 \%$ at W10-DS. High average values from W10-US, W10, and W10-DS are due to a few very high weekly results. The median value may better represent the actual conditions of the stream, rather than the average, since the median is not as easily changed by a few extreme results. The median values of these locations are $2.4 \mathrm{pCi} / \mathrm{L}$ at W10-US, $2.3 \mathrm{pCi} / \mathrm{L}$ at $\mathrm{W} 10$, and $8.4 \mathrm{pCi} / \mathrm{L}$ at W10-DS. The elevated levels in W10-DD and the fact that the average uranium concentration at W10-DS and W-10 are higher than W10-US suggest that the drainage ditch also contributes to the uranium concentrations in Paddys Run (see Table 12 on page A-19). Due to the increase in both the median and average concentration from W9 to W10-US, there is evidence that factors other than the drainage ditch influence the uranium concentration levels in Paddys Run.

Sampling will continue in 1993. With the completion of the Waste Pit Area Runoff Control Removal Action in July 1992, the amount of uranium-contaminated runoff to Paddys Run should be reduced in the future.

\section{Sediment Sampling for Radionuclides}

Contaminants present in surface water can settle or precipitate and thereby accumulate in sediment. Sampling and analysis of sediments provide a way to evaluate possible cumulative effects of routine discharges of treated effluents into the Great Miami River and the effects of stormwater runoff into Paddys Run.

\section{Sampling Methodologies}

Technicians collected sediment samples only at those locations where sediment was most likely to accumulate. In early August 1992, samples were collected from the following locations identified in Figure 34 on the next page:

- Eight locations at 100-meter intervals along the Storm Sewer Outfall Ditch (SSOD);

- Nine locations along the Great Miami River;

- Twelve locations along Paddys Run north of the SSOD;

- Twelve locations along Paddys Run south of the SSOD; and

- Four background locations along Paddys Run, north of the site. 
Figure 34: Sediment Sampling Locations

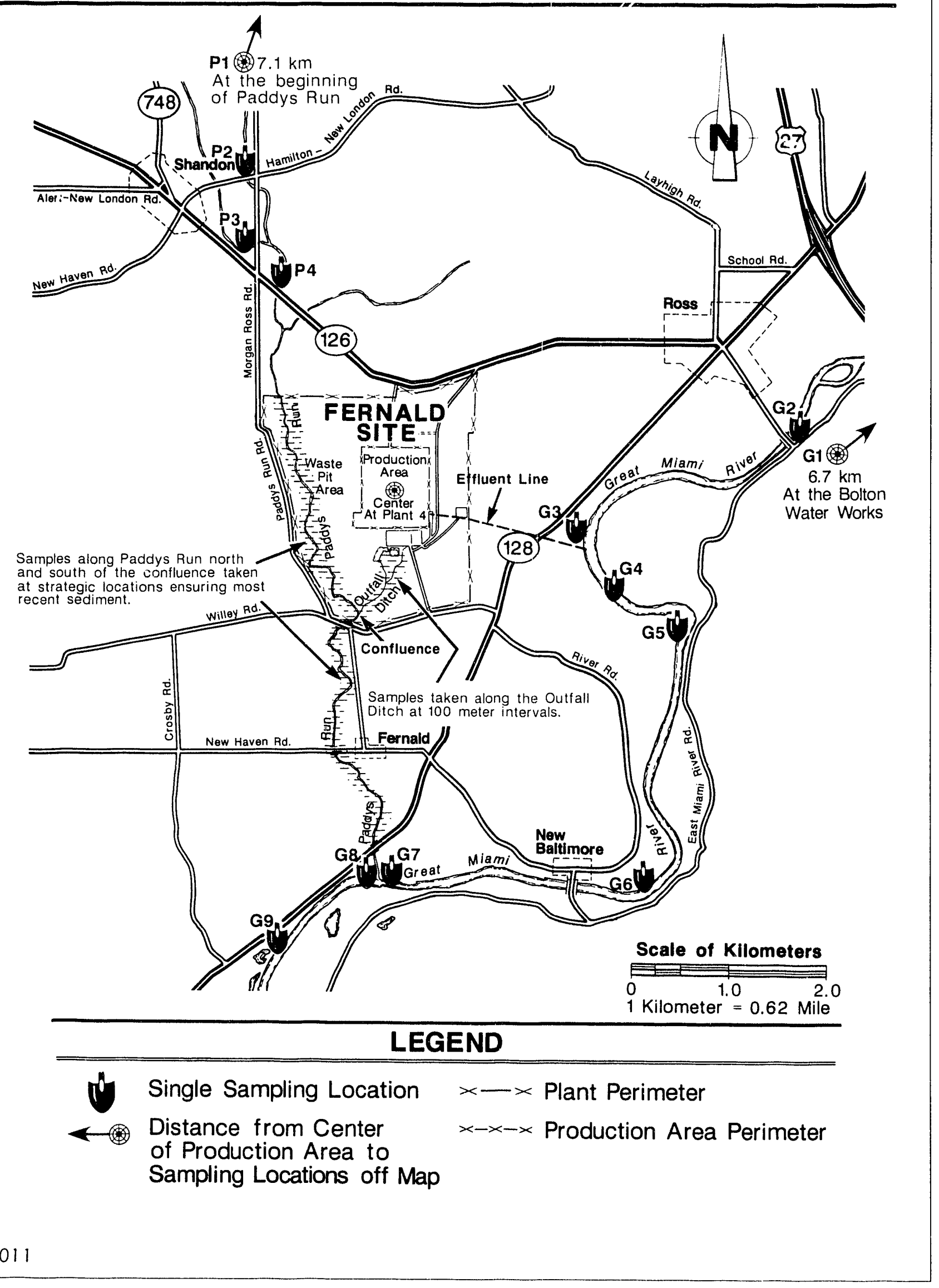


Technicians collected one sample at each location. All samples were taken from strategically chosen locations to ensure that they were representative of the most recent and greatest amount of sediment deposited.

In 1992, all sediment samples were analyzed for total uranium. Samples taken from the SSOD, Paddys Run above the SSOD, and Paddys Run background were also analyzed for radium-226 and isotopes of thorium. There are currently no DOE or USEPA guidelines or standards for uranium or other radionuclides in sediment.

\section{Results of Laboratory Analyses}

The data in Table 13 on page A-21 show there were no noticeable differences in the concentration of uranium and other radionuclides found in sediment samples collected from the Great Miami River upstream and downstream of the site's effluent discharge line. Therefore, the site's liquid effluent discharges did not cause any discernible increase in the levels of radionuclides in Great Miami River sediment.

Total uranium results from Paddys Run locations in 1992 are similar to those of 1991. However, the average uranium concentration in the outfall ditch $(4.3 \mathrm{pCi} / \mathrm{g})$ was still above background levels. Uranium concentrations in individual locations along this ditch have been elevated in previous years as well, probably because of runoff from onsite stormwater flowing into the outfall ditch over the years. With the completion of the Waste Pit Area Runoff Control Removal Action in July 1992, the amount of uranium-contaminated runoff to Paddys Run should be reduced, resulting in lower uranium concentrations in sediments.

\section{Fish Sampling for Uranium}

The fish population of the Great Miami River is another component of the liquid pathway. Fernald site personnel, with the help of a research team from the University of Cincinnati, have been sampling fish in the river for nine years. The sampling team collects fish by electrofishing. This method is among the most efficient methods of collecting fish samples unbiased with respect to size and species.

\section{Sampling Methodologies}

In August 1992, the team collected over 490 fish representing 22 species from four sites along the Great Miami River (see Figure 35 on the next page):

- Site 1-River Mile 37.8 below the Route 127 bridge, north of Hamilton (an additional sample was taken at River Mile 36.5, within 1 kilometer (0.62 miles) of the first Hamilton dam and is grouped with Site 1);

- Site 2 - River Mile 28 at the Bolton Water Works;

- Site 3-River Mile 24 at the Fernald site effluent discharge; and

- Site 4-River Mile 19.3 at the outfall point of Paddys Run. 
Figure 35: Fish Sampling Locations

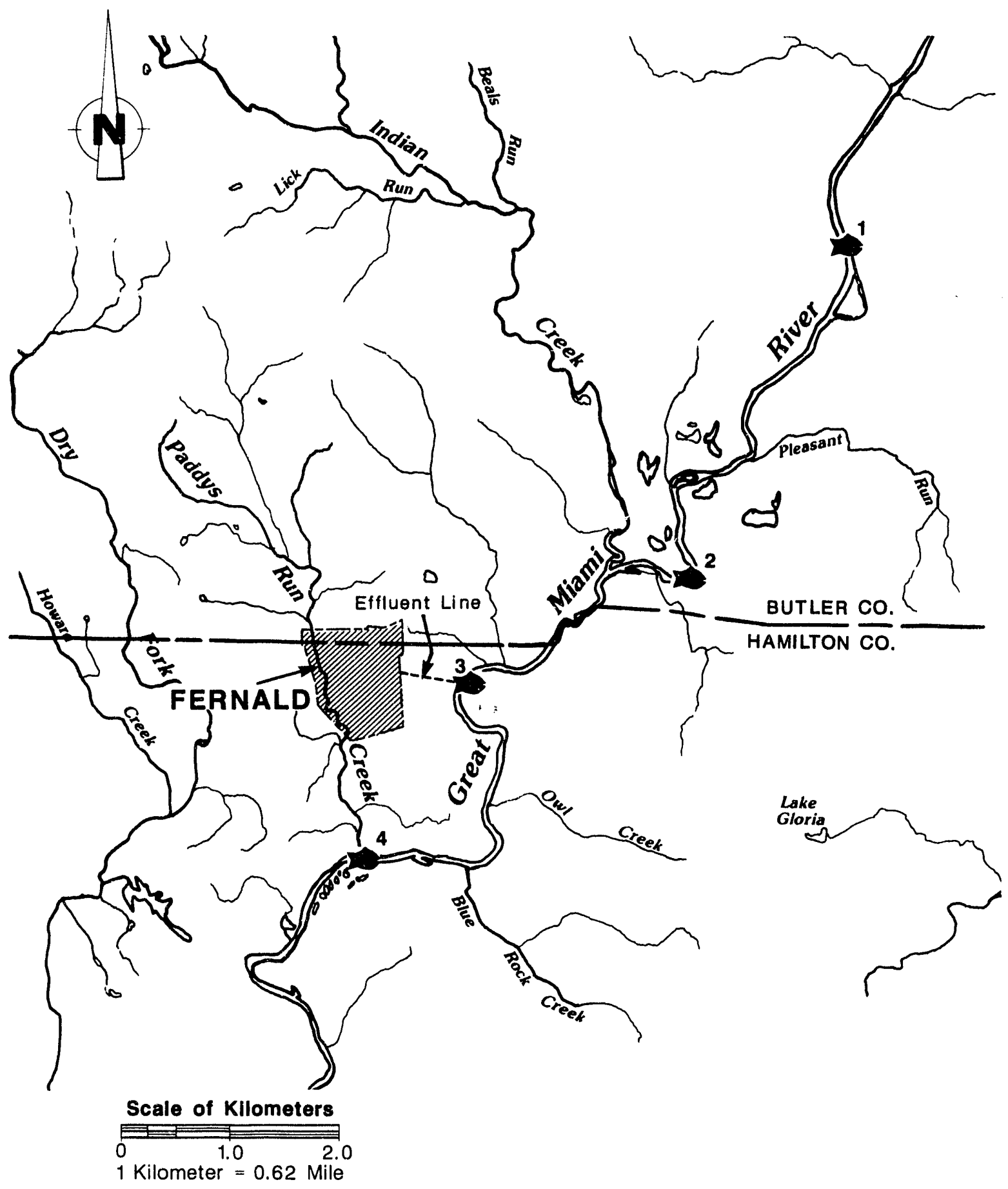

LEGEND

Fernald Site

Sampling Location 
The 1992 collection was made at the same time of year as in 1991. Site 1 is used as a background location because the fish population is physically isolated from downstream activity and migration of fish by the two Hamilton dams, whereas the other locations are not. Sites 2,3 , and 4 have the potential to be influenced by the backwater species that migrate up from the Ohio River. The variety of fish species collected included gizzard shad, skipjack herring, black redhorse, golden redhorse, spotfin shiner, silver banded minnow, largemouth bass, striped bass, smallmouth bass, river carpsucker, drum, bluegill, green sunfish, longear sunfish, longnose gar, sauger, carp, channel catfish, white sucker, smallmouth buffalo, bigmouth buffalo, and flathead catfish.

Overall, the fish population of the Great Miami River has been stable over the course of this study. In 1992, sites 1 and 3 had the highest diversity while site 4 had the lowest. The observed diversity is not statistically different than previous years for the three traditional sampling sites. However, Site 4 had a significantly higher number of young-of-the-year gizzard shad but a similar number of species overall. The fish species appear to be in similar health regardless of sampling location. ${ }^{28}$

Table 14 on page A-22 contains the average for uranium concentrations reported in fish from all four sampling locations. Since all uranium c.oncentrations in fish were not normally distributed, the geometric mean was also provided in order to make meaningful comparisons between locations and/or families. Statistical comparisons were made to determine if:

- The uranium concentrations of all fish caught in any one site were greater than the fish caught from the other three locations,

- Any one family of fish showed higher uranium concentrations when sampled at one location as opposed to the other three locations, and

- The uranium concentrations of all fish in general caught at site 1 (background location) were different from the fish caught at sites 2,3 , and 4 taken collectively.

\section{Results of Laboratory Analyses}

It was statistically proven with $\mathrm{p} \leq 0.05$ that:

- No single location had statistically greater uranium concentrations than the other three locations,

- No single family of fish had significantly greater uranium concentrations when caught at one location than when the same family was caught at the other three locations, and

- No significant difference was found between the average uranium concentrations when fish in general were caught at location 1 versus at locations 2,3 , and 4 taken collectively. ${ }^{29}$

The estimated dose from eating fish caught in the Great Miami River at the Fernald site outfall is discussed in Chapter Seven. 


\section{Monitoring for Nonradioactive Pollutants}

This section of the chapter looks at concentrations of nonradioactive pollutants in the site's liquid effluent, the Great Miami River, and Paddys Run. The site controls the discharge of nonradioactive pollutants in liquid effluent to meet the requirements of the site's National Pollutant Discharge Elimination System (NPDES) permit. Criteria used for nonradioactive contaminants in the river and creek are taken from standards adopted by OEPA. Although no surface water on the Great Miami River downstream from the Fernald site is designated as a source of public drinking water, the site compares concentrations of nonradioactive pollutants in the river (fluoride, nitrate-nitrogen, and $\mathrm{pH}$ ) to drinking water standards as a means of evaluating possible effects from the site.

\section{NPDES Summary for 1922}

The NPDES permitting process for the site is under the jurisdiction of the State of Ohio to control the discharge of nonradioactive pollutants to Ohio waters. The permit specifies sampling locations, sampling and reporting schedules, discharge limits, and other restrictions on the site's effluents discharged to the Great Miami River and Paddys Run. Table 15 on pages A-23 through A-25, zontains the NPDES compliance data for 1992. Out of 6,190 NPDES samples taks in 1992, only 16 were not in compliance (99.7\% compliance). All noncomp'iances were onsite and all discharges to the Great Miami River were within acceptable limits. Fernald site personnel did not collect NPDES samples from Paddys Run since the SWRB did not overflow during 1992.

\section{Surface Water Sampling for Waten-Quality Indicators}

During 1992, Fernald site personnel analyzed weekly surface water samples from the Great Miami River and Paddys Run for fluoride, nitrate-nitrogen, and $\mathrm{pH}$. The 1992 data, presented in Table 16 on page A-26 and Table 17 on page A-27, indicate that operations at the site had minimal, if any, effect on nitrate-nitrogen concentrations or $\mathrm{pH}$ in the Great Miami River. These anion concentrations and $\mathrm{pH}$ levels were all within OEPA standards for water designated for public use. These standards are used only for comparison purposes and do not apply to the site's discharges because OEPA has not designated either Paddys Run or the Great Miami River as public water supplies south of the site. Average concentrations for these anions were the same or only slightly different south of the site than they were at the upstream locations. All average fluoride concentrations were within OEPA standards for a public water supply.

By controlling the concentration of radionuclides in the effluent and by reducing the amount of stormwater runoff to Paddys Run, the site can lessen its impact on the various components of the liquid pathway. In particular, surface water runoff can enter the aquifer and influence groundwater quality. The next chapter looks at the groundwater component of the liquid pathway. 


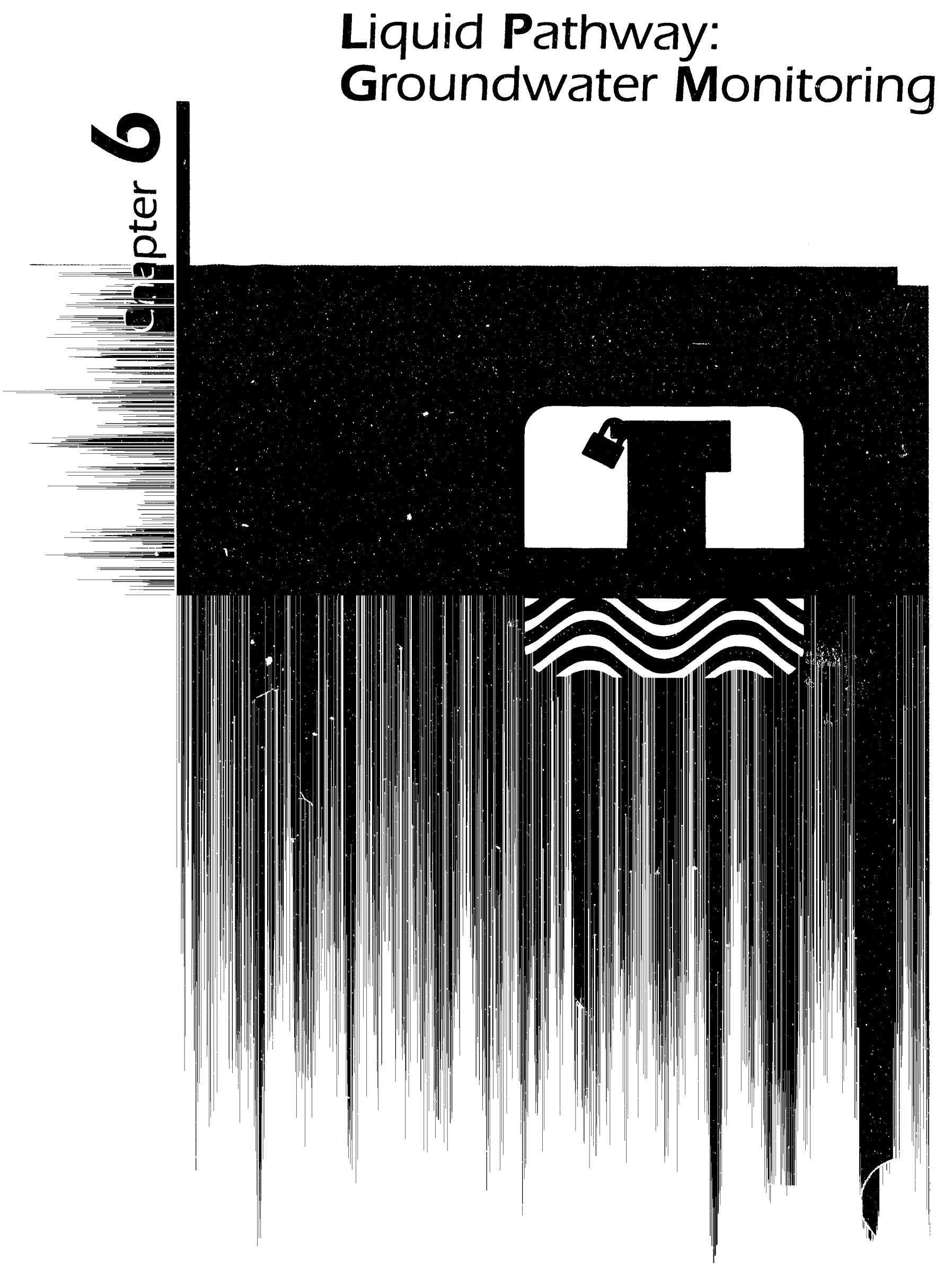




\section{Liquid Pathway: Groundwater Monitoring}

This chapter continues the discussion of the liquid pathway, as surface water running off and leaching through the soil may contaminate the groundwater. The site carefully monitors the groundwater beneath and in the vicinity of the site to identify and track the movement of pollutants which may be present in the Great Miami Aquifer. Scientists can analyze the groundwater and soils sampled during drilling operations to learn much about the soil and its ability to restrict the movement of contaminants into the groundwater. This enables the site to better define the steps it should take to control present contamination and to prevent additional contamination from occurring.

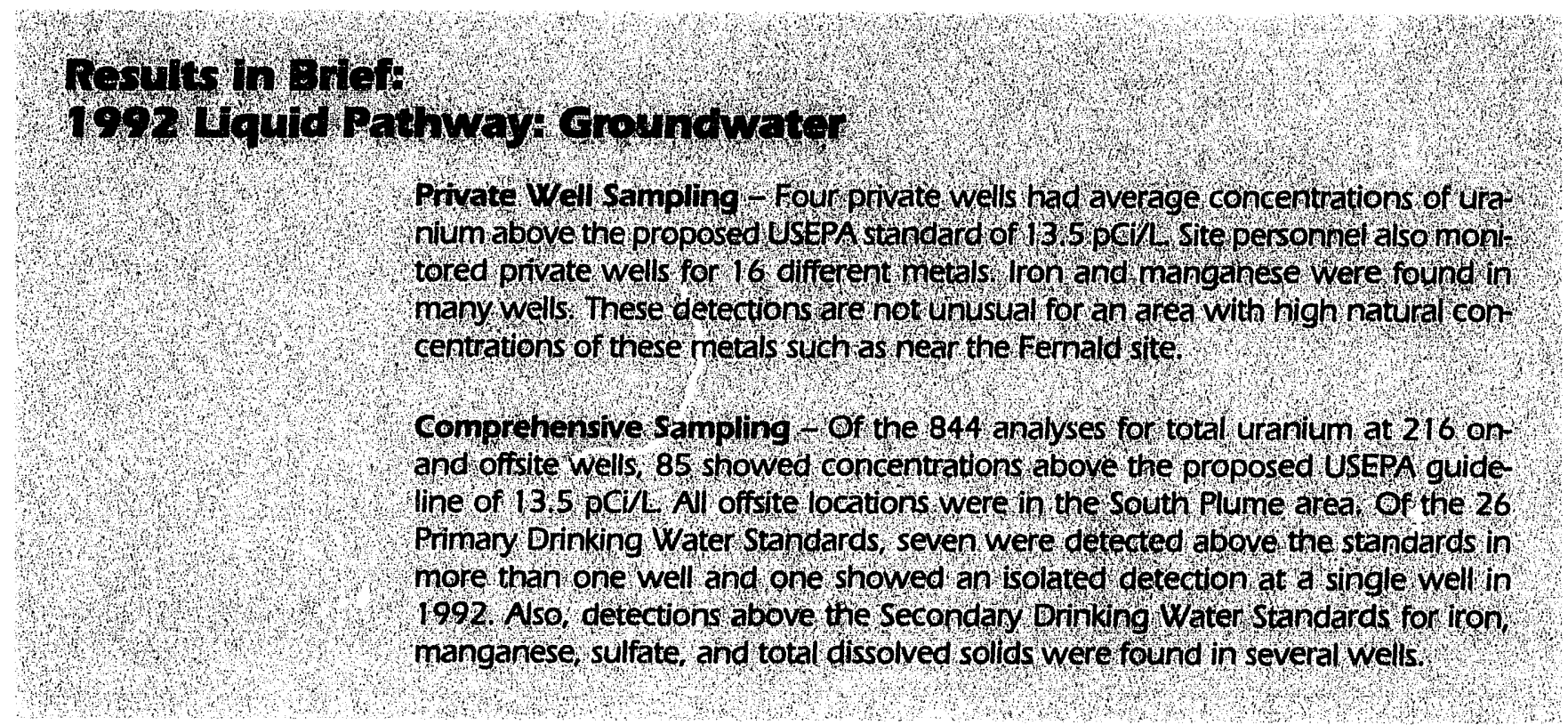




\section{History of Groundwater Monitoring at the Site}

Several groundwater monitoring programs have evolved throughout the history of the site. The original three production wells drilled during the construction of the Feed Materials Production Center in 1951 were the first to be monitored. From 1959 to 1965 , the site installed eleven monitoring wells in the waste pit area to see if pit operations were affecting the groundwater. These waste pit and production area wells constituted the original Environmental Monitoring Groundwater Program.

In late 1981, the State of Ohio sampled three wells south of the site and found elevated levels of beta activity. It was found that this activity was due to potassium40 , a naturally occurring radionuclide which was not present in site production materials. However, sampling also detected above-background concentrations of uranium in other wells near the site. This information was reported to the State in November 1981.

These findings prompted an expansion of groundwater monitoring in the area. Environmental Monitoring began sampling existing area wells in February 1982, and by 1984, the Fernald site officially established the Radiological Enviroinmental Monitoring (Private Well) Program with the monthly sampling of 19 privately owned wells.

Around this same time, the site focused more attention on onsite groundwater contamination. The disposal of barium chloride in Waste Pit 4 from 1980 to 1983 led to the establishment of the RCRA Detection and Groundwater Assessment Programs, separate from the existing environmental monitoring activities. Federal and state environmental regulations required the Fernald site to determine whether or not hazardous waste had entered the groundwater, and, if so, to identify the rate and extent of migration and the concentration of any hazardous waste in the groundwater. When the RCRA Detection Program confirmed suspicions of contamination, the RCRA Groundwater Assessment Program began in May 1988 and has since provided valuable information on the quality of groundwater beneath the waste pit area. (Analytical results of this sampling and assessment can be found in the RCRA Annual Report for 1992.)

Also in May 1988, additional groundwater sampling was initiated as part of the Remedial Investigation and Feasibility Study (RI/FS). This CERCLA-driven study investigates the nature and extent of potential environmental impacts from past and current operations at the site, with particular regard to the Great Miami Aquifer. (More information on the complete RI/FS is presented in Chapter Eleven.)

By late 1989, more than 200 wells were being sampled under the various programs. To eliminate duplication of efforts, all long-term groundwater monitoring responsibilities were shifted to the Environmental Monitoring group. In 1990, this group developed the Comprehensive Groundwater Monitoring Program to coordinate the 
sampling schedules of the original Environmental Monitoring Groundwater Program, the RCRA Assessment Program, and the RI/FS.

Today, as this Comprehensive Groundwater Monitoring Program monitors siteowned wells in accordance with the applicable regulations, the private well sampling program continues under Radiological Environmental Monitoring as a service to local residents and as an additional source of offsite groundwater information. Results are presented in this chapter as either private well results or as comprehensive sampling results.

\section{Monitoring for Radioactive Pollutants}

As part of the total liquid pathway, the rnovement of radioactive pollutants into and through the groundwater is of significant concern. This section discusses the results of private well sampling and of the Fernald site's comprehensive sampling program.

\section{Private Well Sampling for Uranium}

The Radiological Environmental Monitoring Program encompasses all sampling of privately owned wells. The program itself is divided into non-routine sampling and routine sampling.

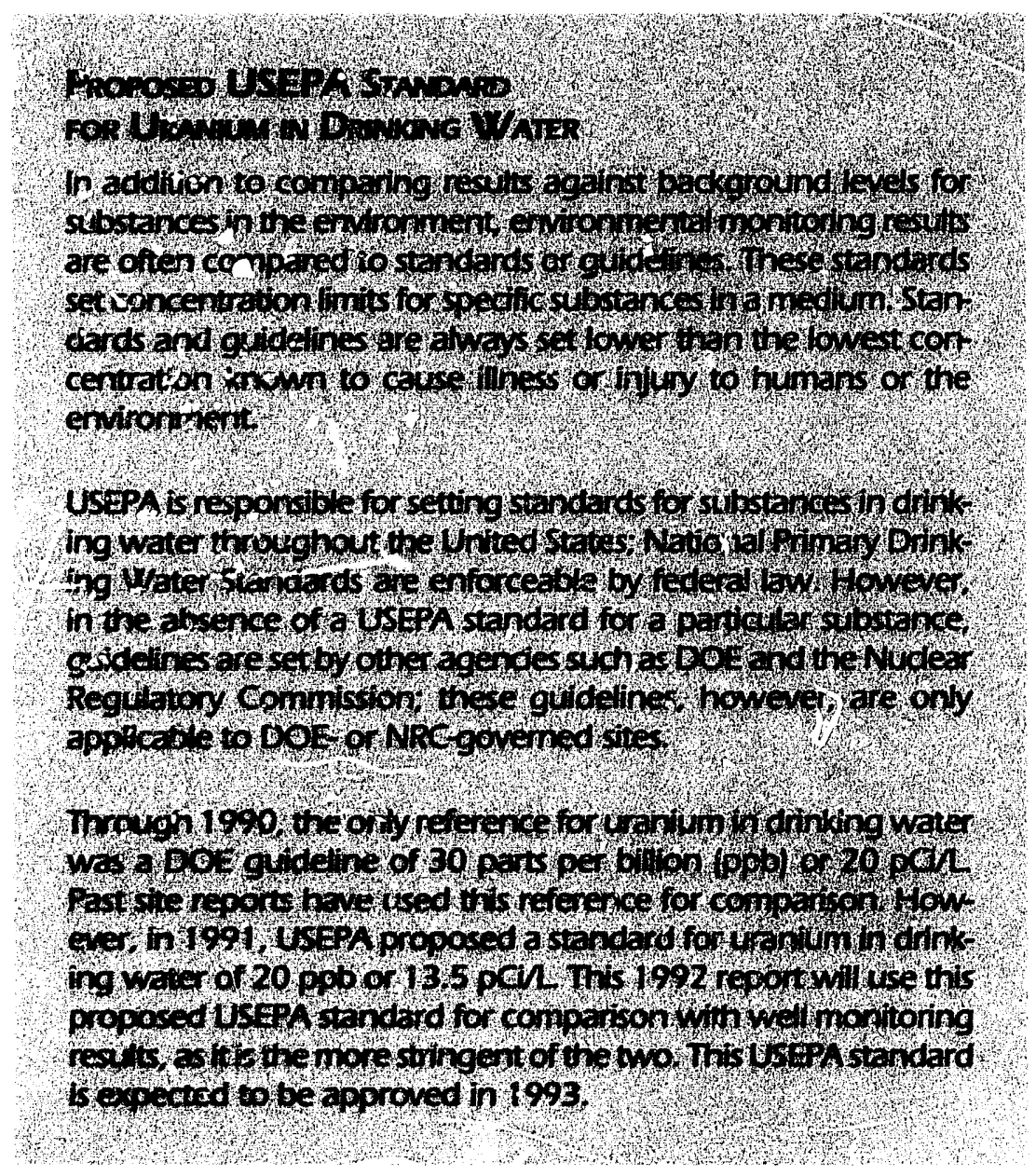

At a property owner's request, any drinking water well near the site will be sampled for uranium tc gain additional information about local groundwater quality, and the one-time sample results are reported to the well owner. If one of these "special request" samples shows a questionable or significant total uranium concentration, or if the well is believed to be representative of an area based on its location, the property owner has the option to participate in the routine sampling program. This program has grown from 19 wells in 1984 to 37 wells in 1992. (Wells 55 and 56 were added to the program during 1992; well locations are shown in Figure 36.) The data from the routine sampling program are presented in Table 18 on page A-28. Figure 37 on page 99 shows average uranium concentrations found in private wells from 1988 to 1992. 
Figure 36: Private Well Monitoring Locations

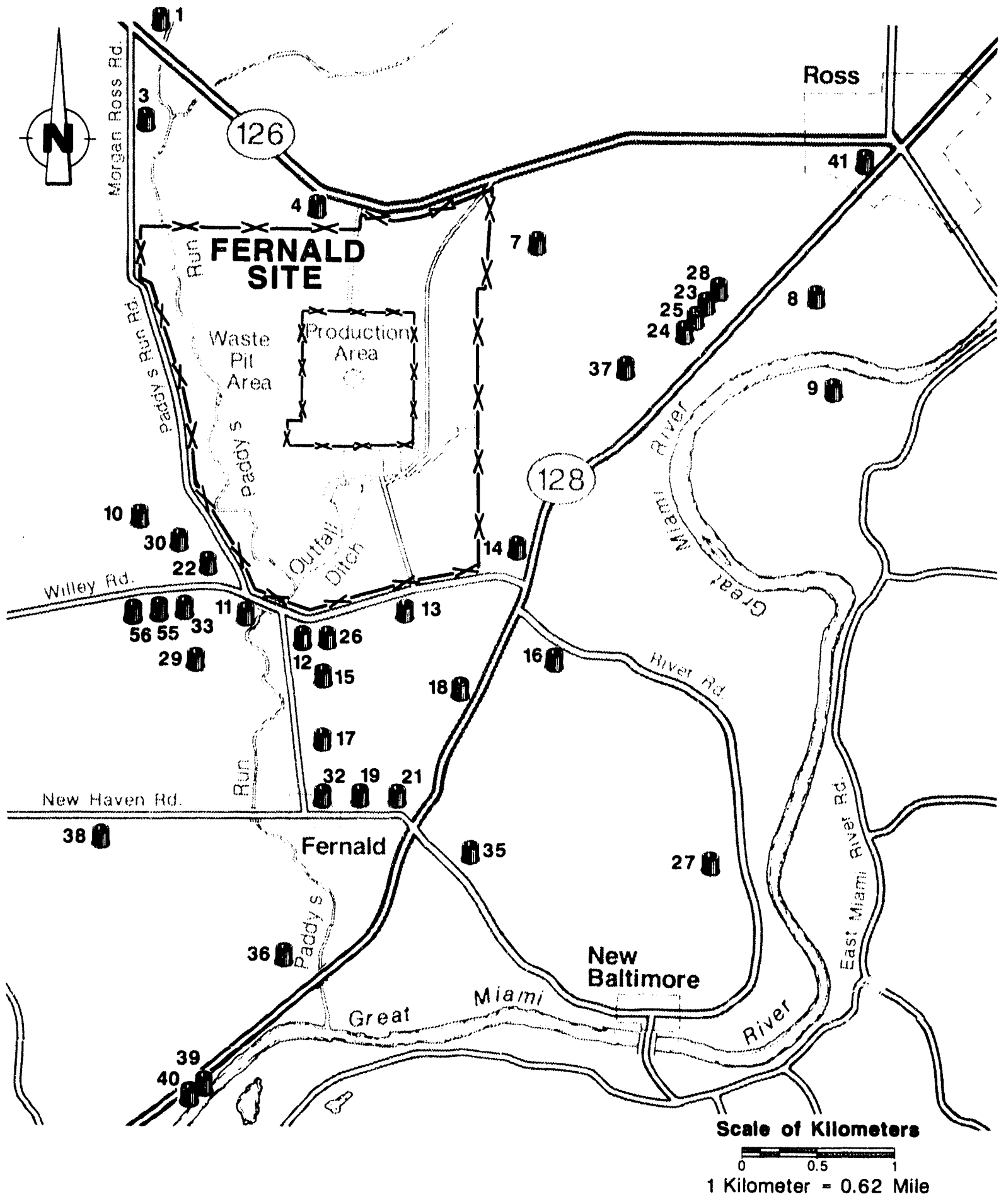

LEGEND

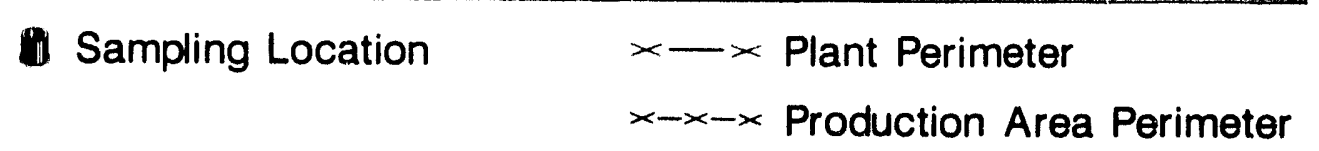


Figure 37: Average Uranium Concentrations in Private Wells, 1988 - 1992
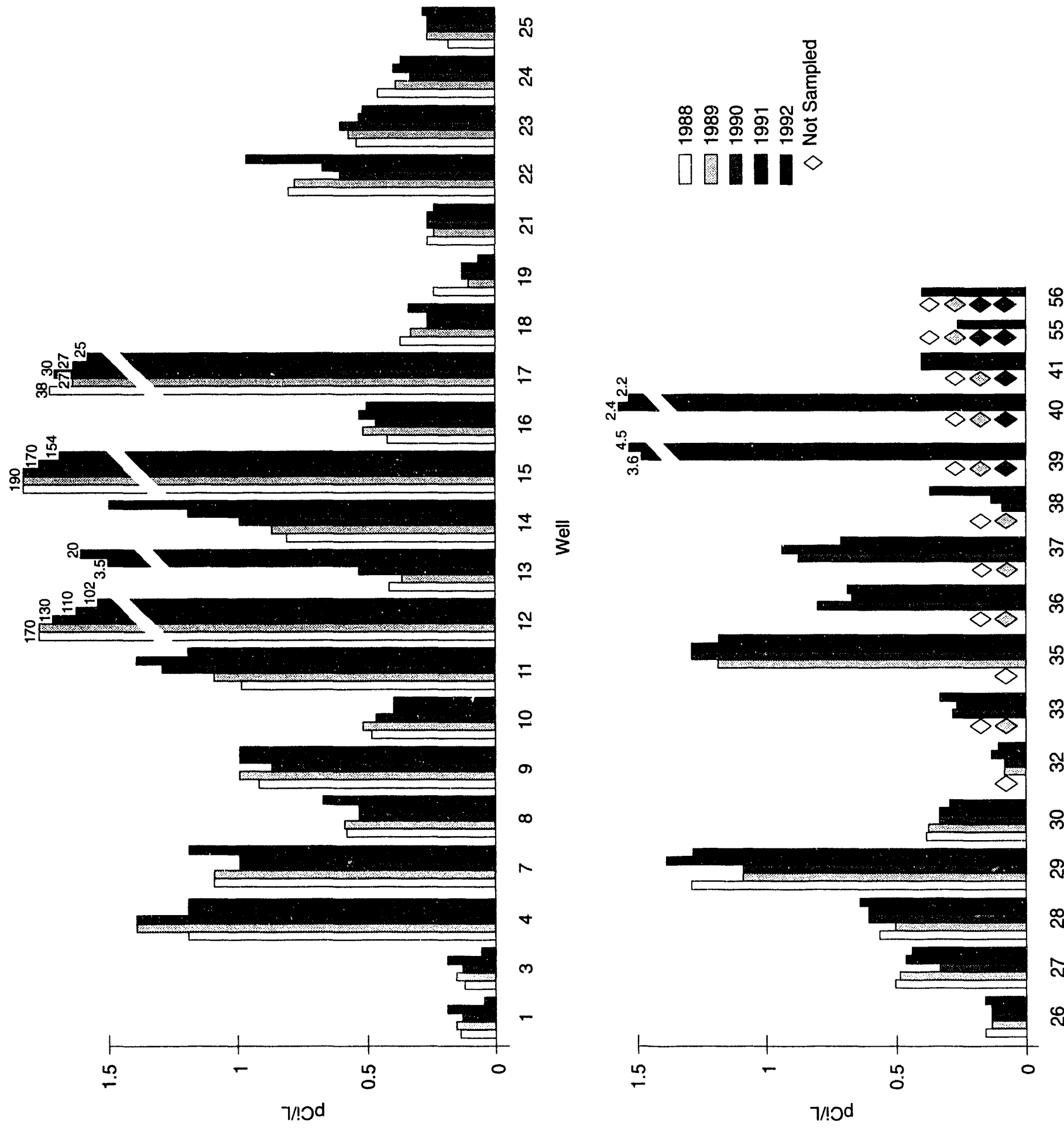

เำ 
During 1992, the 37 offsite wells belonging to individuals and companies in the vicinity of the site were sampled monthly and analyzed for total uranium. Average uranium concentrations in all but six wells were less than $2 \mathrm{pCi} / \mathrm{L}$ and, therefore, less than $15 \%$ of the proposed USEPA standard. Only wells $12,13,15$, and 17 exceeded this proposed standard in 1992. These concentrations can also be compared to national background levels for total uranium in groundwater of 0.068 to $6.8 \mathrm{pCi} / \mathrm{L}$ or local background levels of 0.068 to $2.03 \mathrm{pCi} / \mathrm{L}$, which scientists have determined using a $95 \%$ confidence interval. ${ }^{30,31}$

Well 13 has again shown increasing uranium concentrations. In June 1992, an ion exchange system was installed at this location. This system is designed to remove the uranium from the well water by filtering the water. Results from the water filtered through the ion exchange system indicate that the uranium is removed and the uranium concentration in the treated water is within the background range for this area. Well 13 is located just south of the site, in an area of known groundwater contamination, and continues to be a point of monitoring.

The uranium-contaminated water in this area, known as the South Plume, will be pumped from the aquifer as part of the South Groundwater Contamination Plume Removal Action, discussed further in Chapter Eleven. The plume itself is discussed later in this chapter.

\section{Comprehensive Sampling for Uranium}

The Comprehensive Groundwater Monitoring Program encompasses all sampling of site-owned monitoring wells. Groundwater monitoring personnel do not monitor all wells each quarter, nor do they monitor all wells for the same constituents. As discussed earlier, site personnel sample as necessary to provide each of the groundwater monitoring subprograms with a complete database for reporting purposes. However, when taken together, as done here, the comprehensive sampling results present a rather detailed and complete description of groundwater under and around the site.

The movement of uranium in the groundwater has been a key factor in determining the sources of contamination in the area. In 1992, the Groundwater Monitoring Program received results from 844 analyses for total uranium from samples at 216 onand offsite locations. Of these uranium analyses for 1992, the highest concentration was $3,243 \mathrm{pCi} / \mathrm{L}$, well above the proposed USEPA standard of $13.5 \mathrm{pCi} / \mathrm{L}$. This sample was drawn from Well 1085 in the glacial overburden directly beneath the northeast corner of the production area. Other above-guideline detections at this same location were $2,714 \mathrm{pCi} / \mathrm{L}$ and $2,702 \mathrm{pCi} / \mathrm{L}$. Most above-guideline detections at the other sampled wells were below $689 \mathrm{pCi} / \mathrm{L}$. Uranium concentrations in 82 other samples at 25 onsite and 12 offsite locations were also above the USEPA drinking water guideline. (All 12 offsite locations were in the South Plume area, currently being addressed by a RI/FS removal action - see Chapter Eleven.) These 85 above-guideline sample concentrations and their relative locations are listed in Table 19. 
Figure 38: Well Diagram*

This diagram depicts the construction of a typical well used for sampling groundwater. These wells are located both on and off the Fernald site. They range from $11-76$ meters ( 35 - 250 feet) deep.

\section{Fernald Ste Groundwater Welus}

Figure 38 depicts a typical well at the Femald site. The depth of a Fernald site well and the waterbearing zone into which it extends are denoted by the first digit of the well number (see Figure 39). Wells extending into the perched ground. water within the till are denoted as 1000 -series wells. Wells extending into the upper portion of the sand and gravel aquifer are denoted as 2000 series wells. The 3000 -series wells are placed within the middle portion of the sand and gravel aquifer, and the 4000 -series wells are installed in the sand and gravel aquifer beneath a layer of "blue clay." Sometimes a group of two or more wells of different depths are drilled at the same location to sample different water-bearing zones within the groundwater; these groups are called cluster wells.

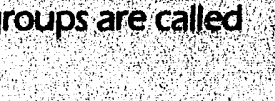

* Not Drawn to Scale
Vent Hole Inner Well Cap

$\leftarrow$ Weep Hole
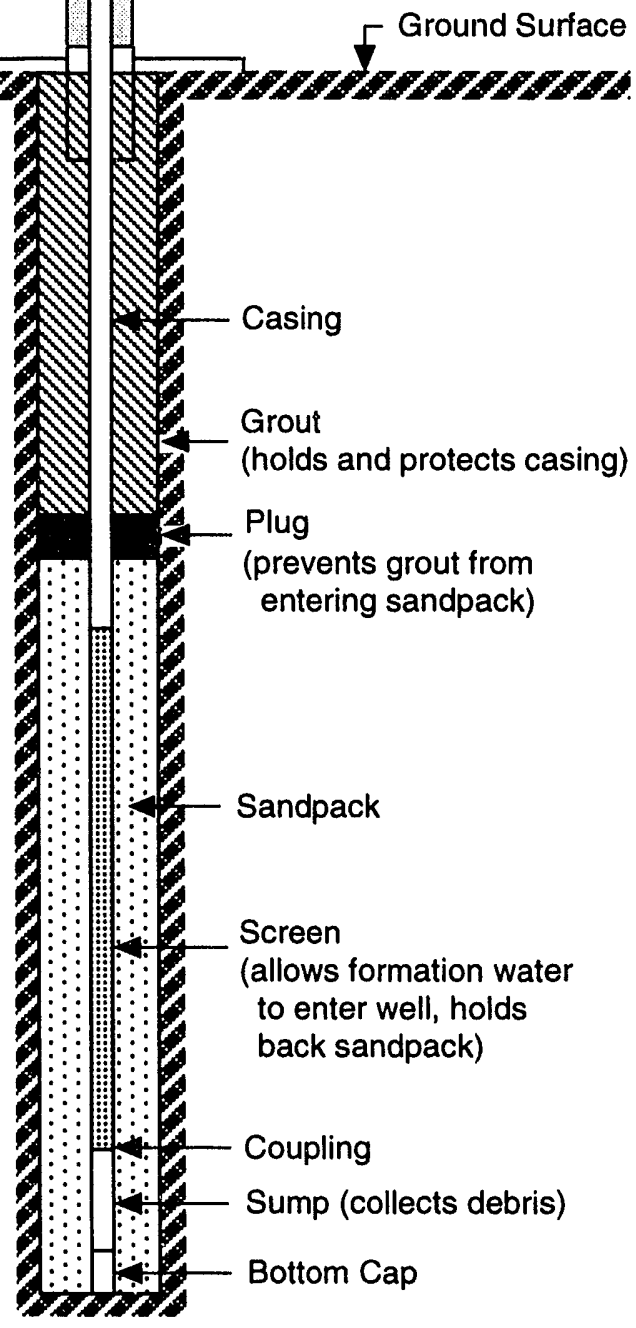
Figure 39: Monitoring Well Depths and Screen Locations

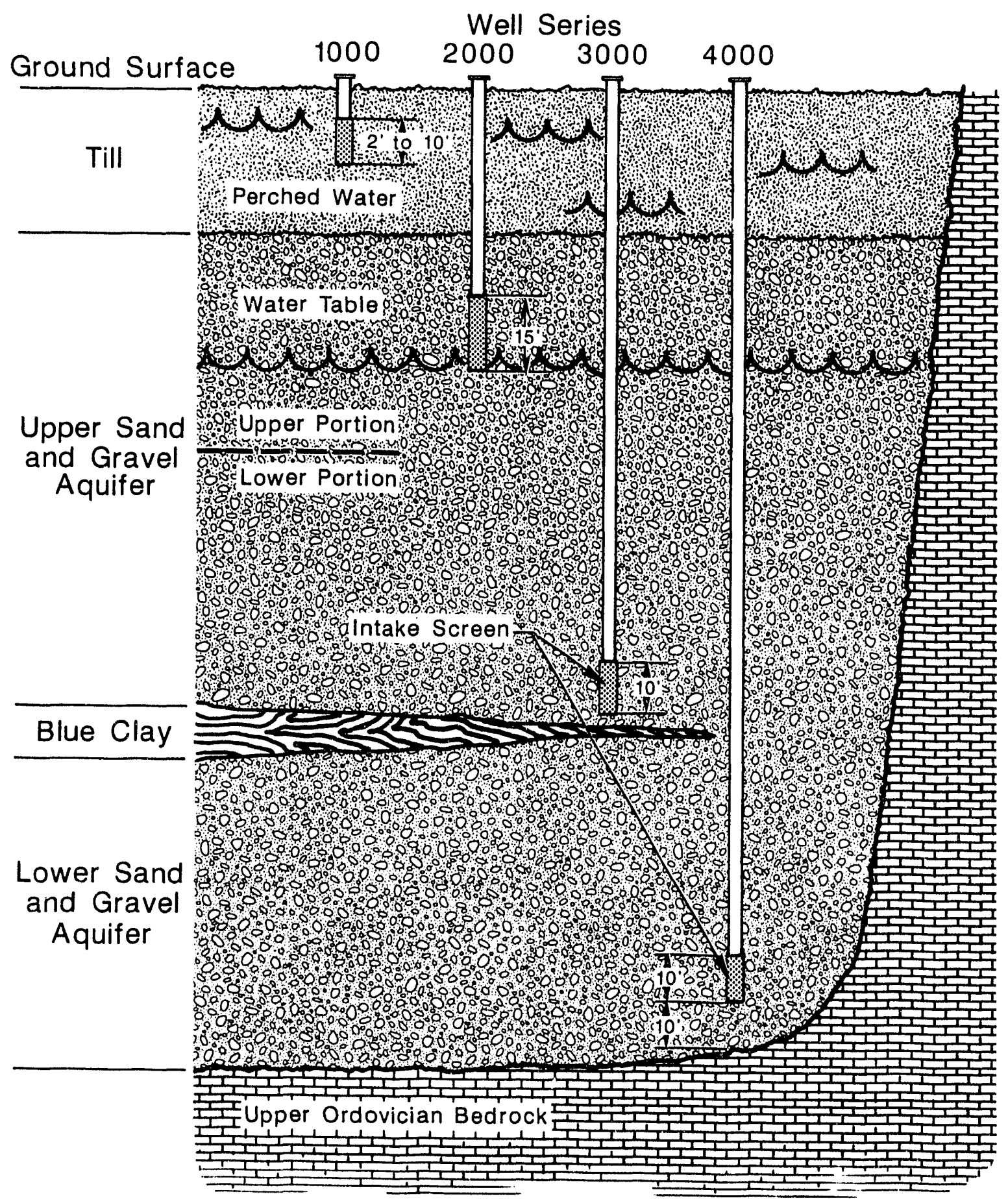




\section{Comprehensive Groundwater Monitoring for Other Radionuclides}

The Comprehensive Groundwater Monitoring Program also samples for radium, strontium, technetium, and thorium. Gross alpha activity, gross beta activity, cesium, plutonium, ruthenium, and neptunium in the groundwater are also monitored as indicators of radionuclide contamination. Results from 1991 monitoring for radionuclides were not available in time to include in the 1991 Annual Site Environmental Report. These results are considered suspect at this time due to laboratory problems and are not presented in this report. The results from sampling for radionuclides in 1992 also cannot be reported with any assurance of data quality. If the problems with the data validation are resolved, these 1991 and 1992 results may be reported in future reports.

\section{South Groundwater Contamination Plume}

Groundwater monitoring results over the past several years have led to the identification of the South Groundwater Contamination Plume, an area immediately south of the site with known levels of uranium contamination. Contamination from the site flows with the groundwater, generally to the east and south, toward the Great Miami

\section{Public Water Supply Program}

DOE has supplied bottled water to homeowners whose private wells have been impacted by the South Plume. This action is, however, considered only a temporary solution. The preferred alternative is to eliminate individual homeowner wells that withdraw water from the aquifer and to provide these residents with water from a public water supply.

The primary objective of this program is to protect public health by providing this permanent, reliable, and safe water supply to local residents. DOE has committed to providing its fair share of the cost for installation of the water mains in the South Plume area. This funding is in conjunction with the Hamilton County Department of Public Works, the agency responsible for coordinating all water supply within Hamilton County.

The portion of this proposed action that is of concern to DOE involves the installation of approximately $23 \mathrm{~km}$ (14 miles) of pipeline within Hamilton and Butler counties. This installation will occur along East Miami River Road from Bolton Water Works to the intersection of state routes 126 and 128 , then south along State Route 128 to approximately $2.7 \mathrm{~km}$ (1.7 miles) south of the New Haven Road intersection. Installation will also occur along Willey, New Haven, and Paddys Run roads.

The estimated duration of the entire project is two years. This time frame includes design, review, the bidding process, contract award, and construction. The overall schedule is contingent on the construction schedule of Hamilton County, but the tentative completion date of the public water supply is set for the summer of 1994.
River. Therefore, wells to the north or west of the site should not show increased concentrations of site contaminants, whereas wells to the south and east may show increased concentrations.

Because groundwater in the Fernald area travels very slowly as compared to surface water, some areas may not see the effects of the contamination for years. Also, since the contamination moves in about the same direction as the groundwater, environmental monitoring personnel can track the movemen" of this plume by monitoring the movement of the groundwater. Figure 40 show: the area of uranium contamination in the upper sand and gravel aquifer above the proposed USEPA standard of $13.5 \mathrm{pCi} / \mathrm{L}(20 \mathrm{ppb})$ as it appeared at the end of 1992. 
Figure 40: South Groundwater Contamination Plume

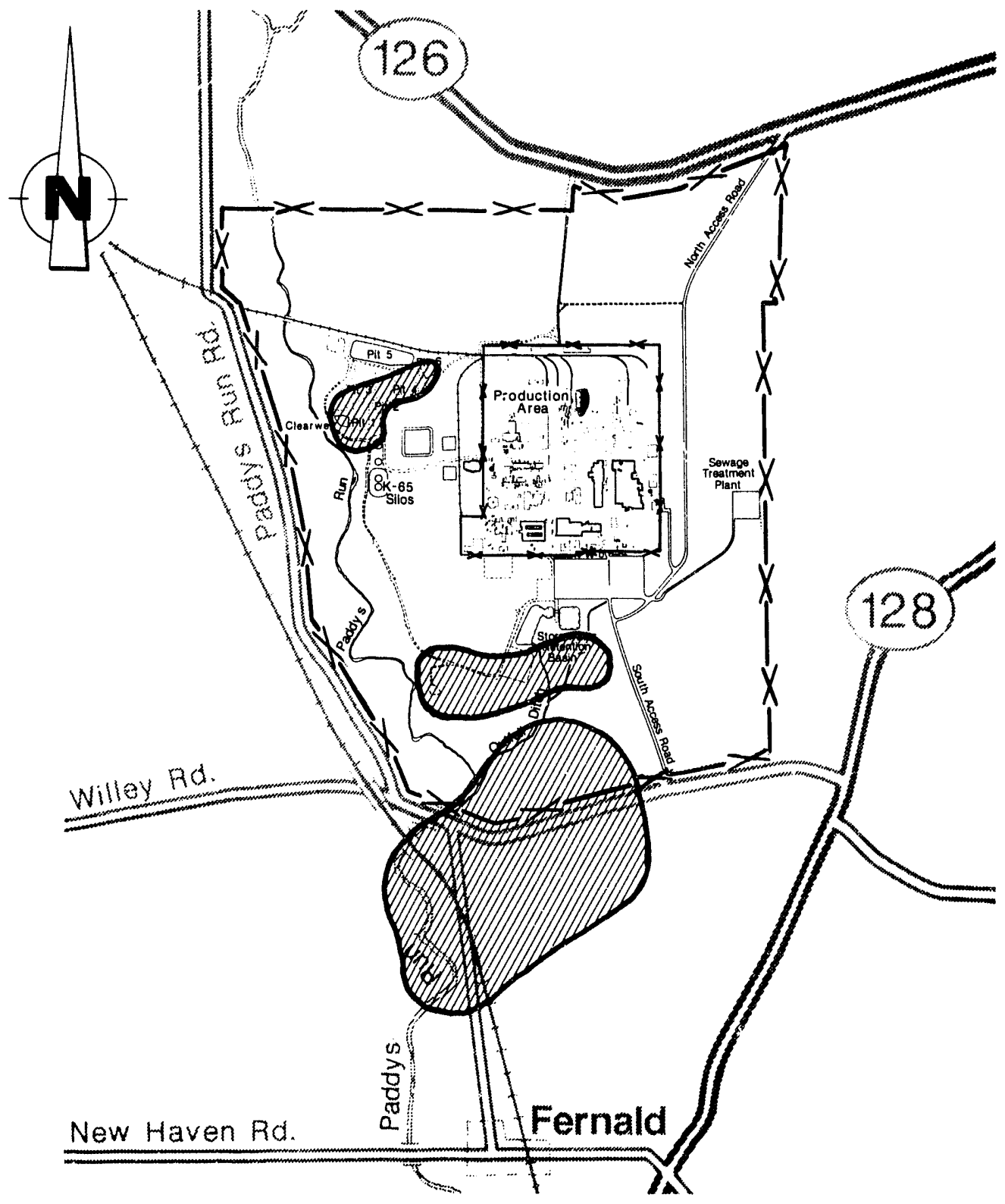

Scale of KIlometers

1 Kilometer $=0.62$ Mile

LEGEND

Area of Total Uranium

Exceeding 20 parts per billion $x-\times$ Plant Perimeter

$\times-x-x$ Production Area Perimeter 
The South Groundwater Contamination Plume Removal Action was initiated to restrict further southward movement of the plume, to limit access and exposure to contaminated groundwater, and to protect the groundwater environment. This removal action is discussed in detail in Chapter Eleven under "Operable Unit 5."

\section{Monitoring for Nonradioactive Pollutants}

Protection of the Great Miami Aquifer also includes monitoring for a number of nonradioactive pollutants and general water quality indicators. Site technicians generally sample for those constituents listed in the National Primary and Secondary Drinking Water Standards. Primary standards apply to those substances that pose definite health threats if present beyond the regulated concentrations; secondary standards control contaminants that primarily affect the aesthetic qualities of drinking water and are not federally enforceable. ${ }^{32}$ In addition to these USEPA-listed constituents, the RCRA wells within the Comprehensive Groundwater Monitoring Program are sampled for many RCRA-listed constituents.

\section{Private Well Sampling for Metals}

The 1992 samples from the private wells were analyzed for the 16 metals listed in Table 20 on pages A-31 through A-33. Of these 16 metals, no DOE or USEPA standards have been established for calcium, magnesium, nickel, potassium, or sodium. Although concentrations of iron and manganese were higher than the secondary drinking water guidelines in a number of wells, high concentrations of those natural elements are typical for groundwater in this area., 11, ${ }^{42}$ All other metal concentrations were well within the appropriate guidelines.

\section{Comprehensive Sampling for Hazardous Substances}

The Comprehensive Groundwater Monitoring Program monitors for nonradioactive constituents in the groundwater to identify areas that might have harmful chemical concentrations as a result of production operations. All site wells sampled under the comprehensive program are analyzed for metals, volatile organic compounds (VOCs), and water quality indicators listed in the National Primary and Secondary Drinking Water Standards.

This section focuses on the incidences in which these constituents occur above the applicable standards. In addition, those wells with detections above the primary standards and the DOE guideline for uranium are mapped in Figures 41 through 44 beginning on page 107 . 


\section{Detections above Primary Standards}

The site analyzes its comprehensive groundwater samples for 10 metals and 16 VOCs which have applicable Primary Drinking Water Standards. These constituents, which are known to be a threat to human health in high concentrations are:

\section{Metals}

- Arsenic

- Barium

- Cadmium

- Chromium

- Fluoride
- Lead

- Mercury

- Nitrate

- Selenium

- Silver

\section{Volatile Organic Compounds (VOCs)}

- Benzene

- Carbon tetrachloride

- 2,4-D

- para-Dichlorobenzene

- 1,2-Dichloroethane

- 1,1-Dichloroethylene

- Endrin

- Lindane
- Methoxychlor

- 2,4,5-TP Silvex

- Toxaphene

- 1,1,1-Trichloroethane

- 1,1,1-Trichloroethene

- Trichloroethylene

- Total trihalomethanes

- Vinyl chloride

Of these 26 harmful constituents, seven were detected above the primary standards in more than one well in 1992. Also, mercury showed a single detection above its standard of 0.002 at a well in the production area (see Table 21 on pages A-34 and A-35).

The first of the repeated contaminants was arsenic in four wells. These wells are located in the silo area, the northwest sector of the site along Paddys Run Road, and south of the production area. There were seven detections ranging from 0.07 to 0.22 $\mathrm{mg} / \mathrm{L}$. The standard for arsenic is set at $0.05 \mathrm{mg} / \mathrm{L}$.

Barium was detected above its standard of $1 \mathrm{mg} / \mathrm{L}$ at five wells. These detections ranged from 1.1 to $1.4 \mathrm{mg} / \mathrm{L}$, and they were located in the silo area, the production area, and Paddys Run Road.

Fluoride has a standard of $4 \mathrm{mg} / \mathrm{L}$. It was detected at three wells, and the detections ranged from 5.0 to $7.7 \mathrm{mg} / \mathrm{L}$. One of these wells is located in the silo area, and the other two are located just east of the production area.

Seven wells showed eight detections of lead above the standard of $0.05 \mathrm{mg} / \mathrm{L}$. These detections ranged from 0.06 to $0.25 \mathrm{mg} / \mathrm{L}$. Most of these wells are in the production area. Other detections were found in the silo area and along Paddys Run Road. 


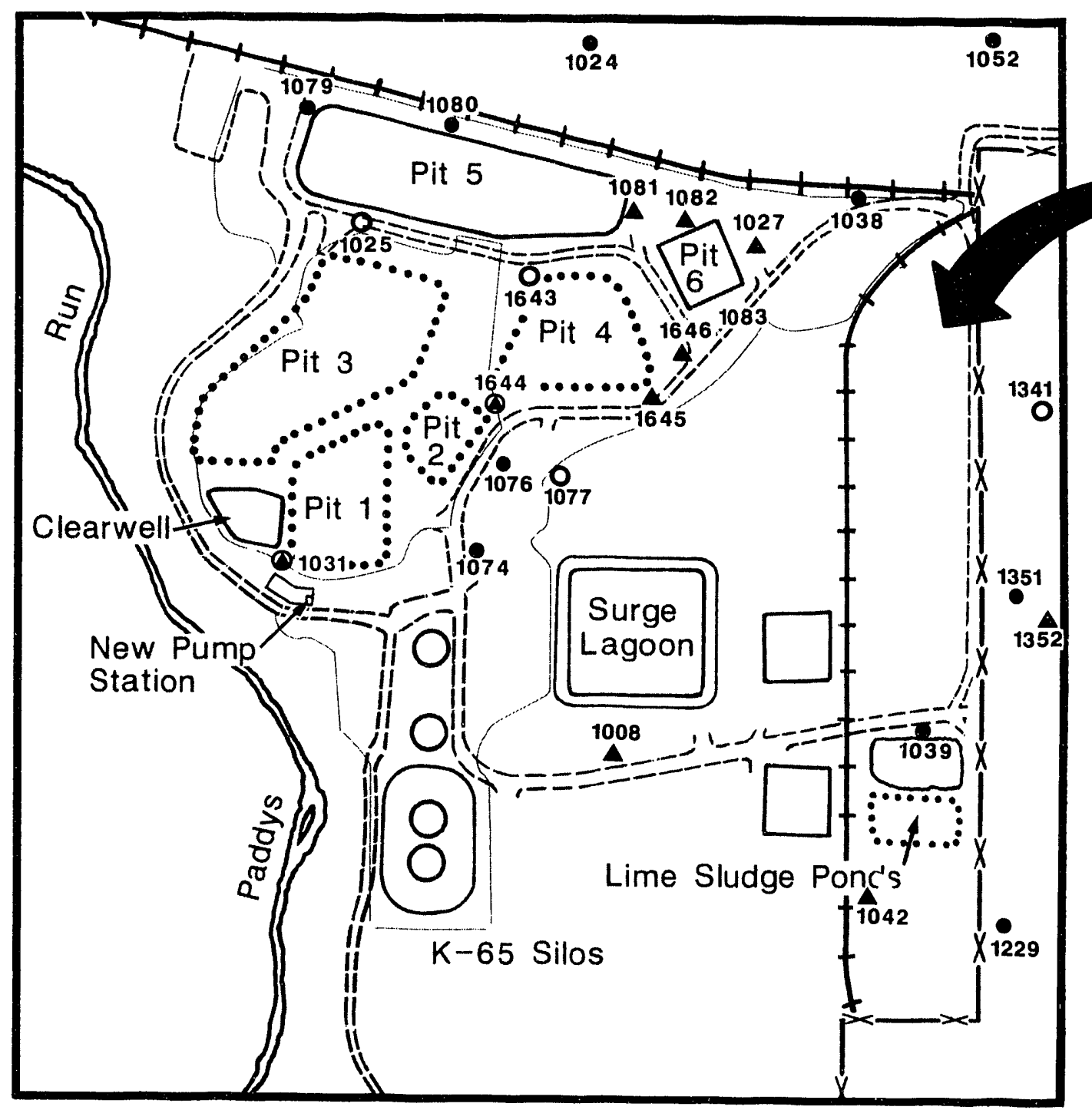




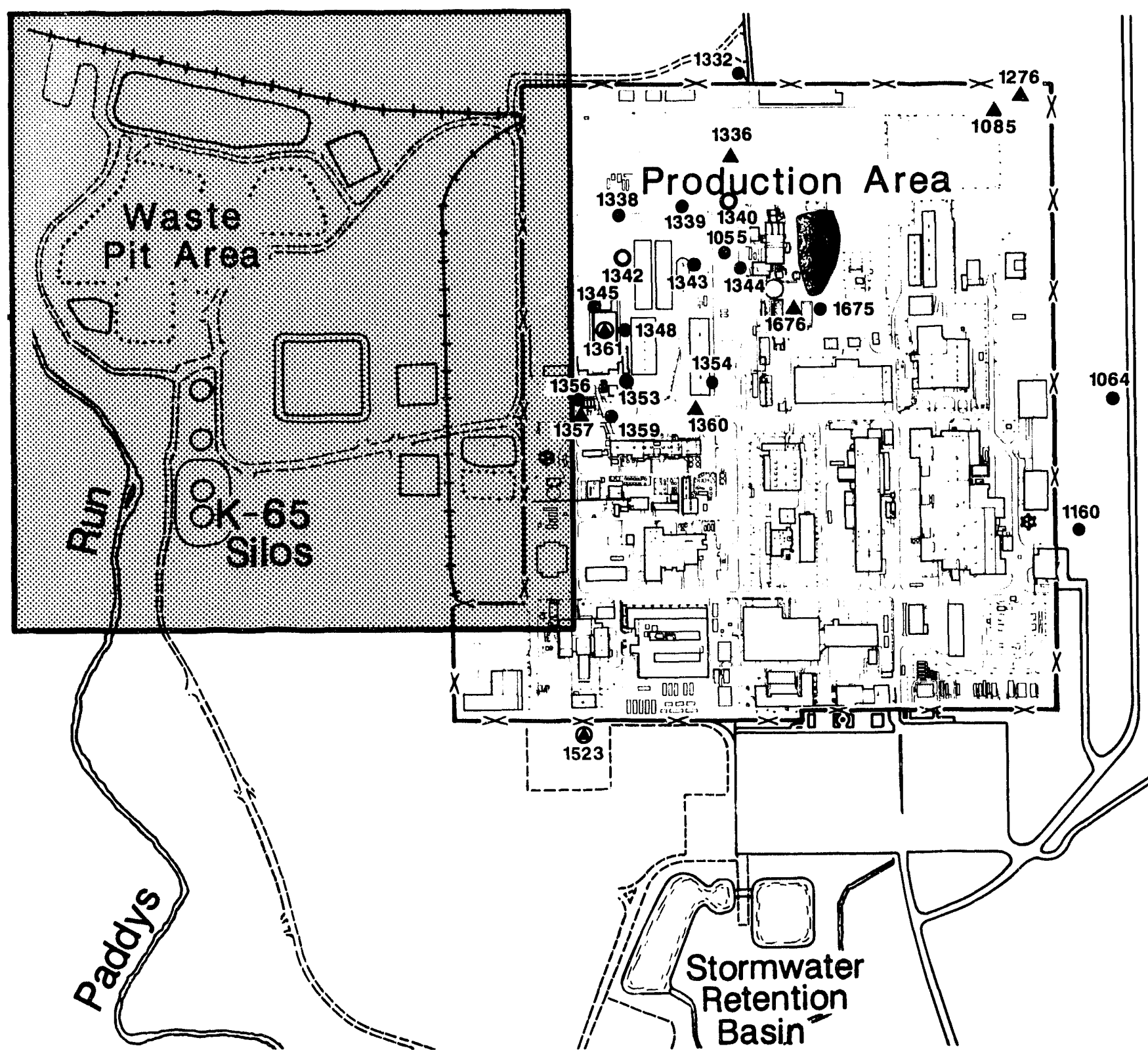

\section{LEGEND}

- 1000 Series Well

00000 Primary NDWS Detection $\triangle 0000$ Proposed USEPA Standard Total U Detection

$\odot 0000$ Primary and Total U Detection 


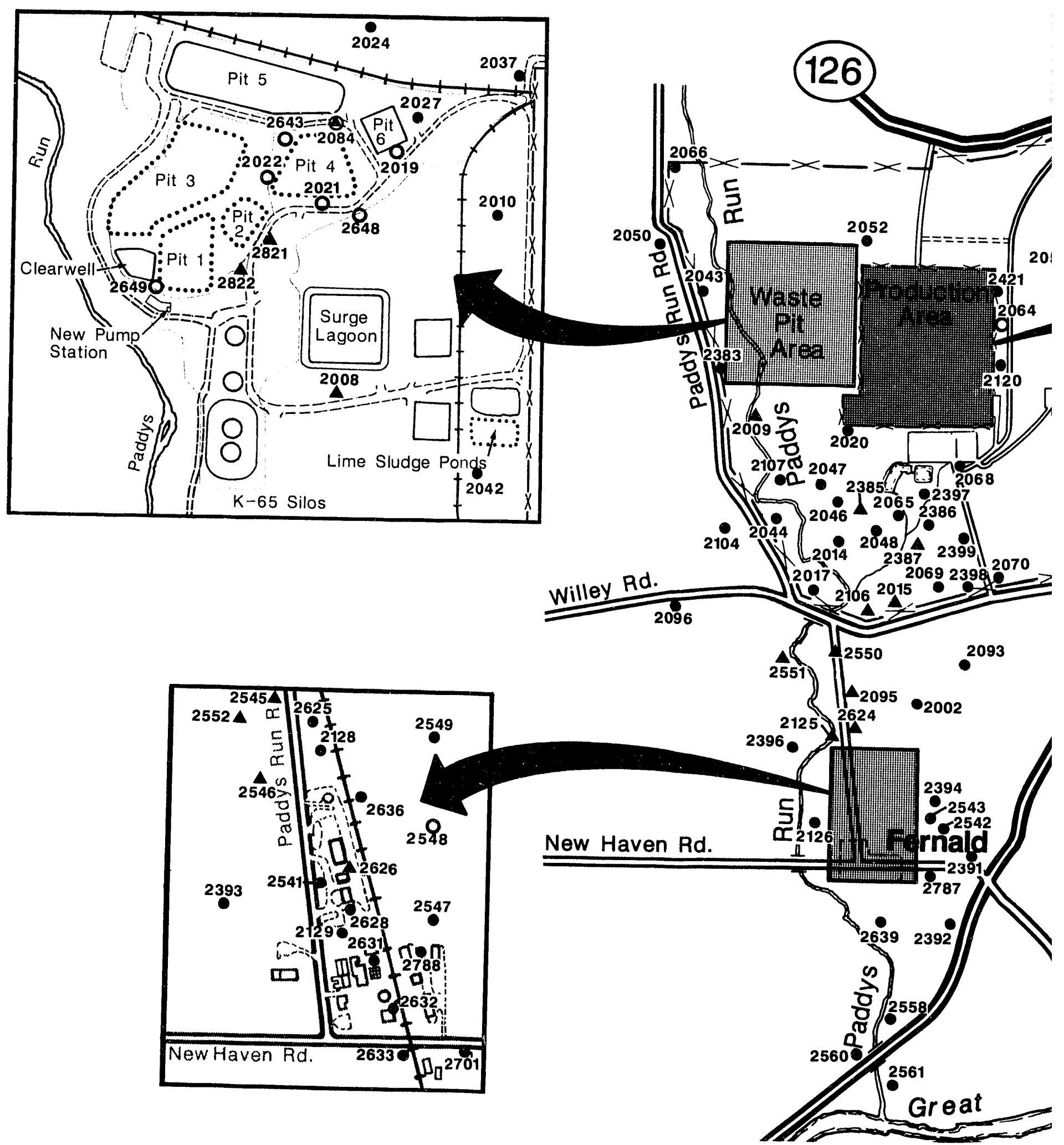



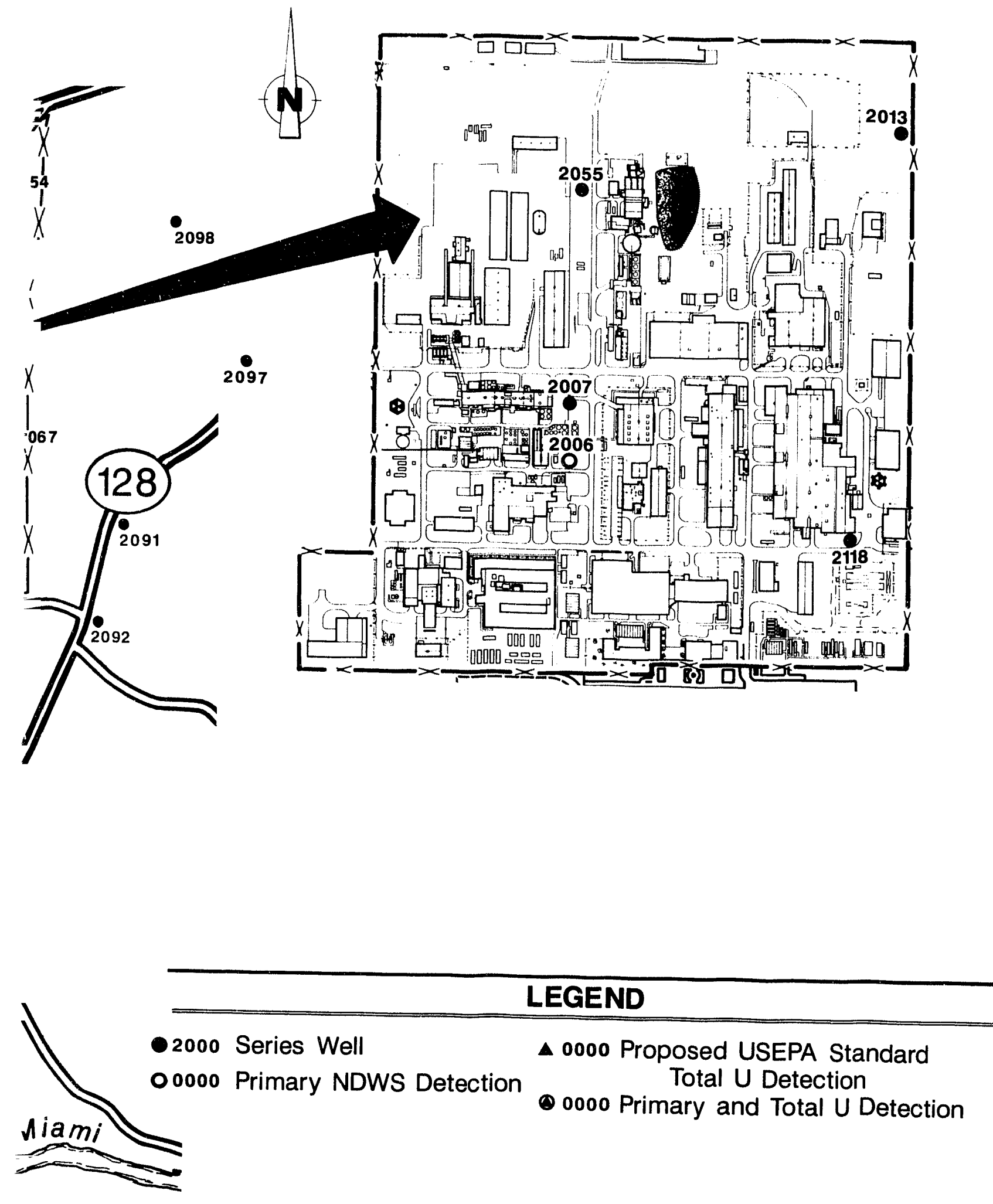
Figure 43: 3000-Series Wells
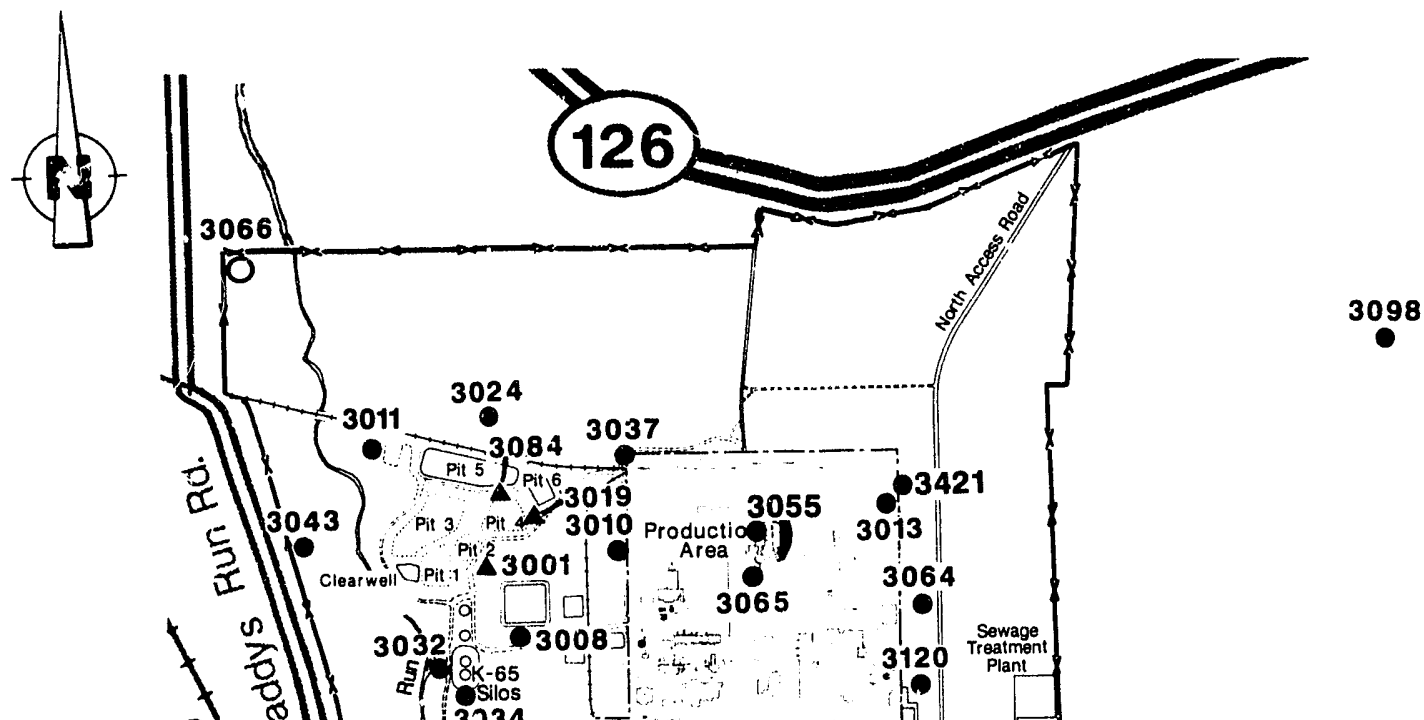
10 क
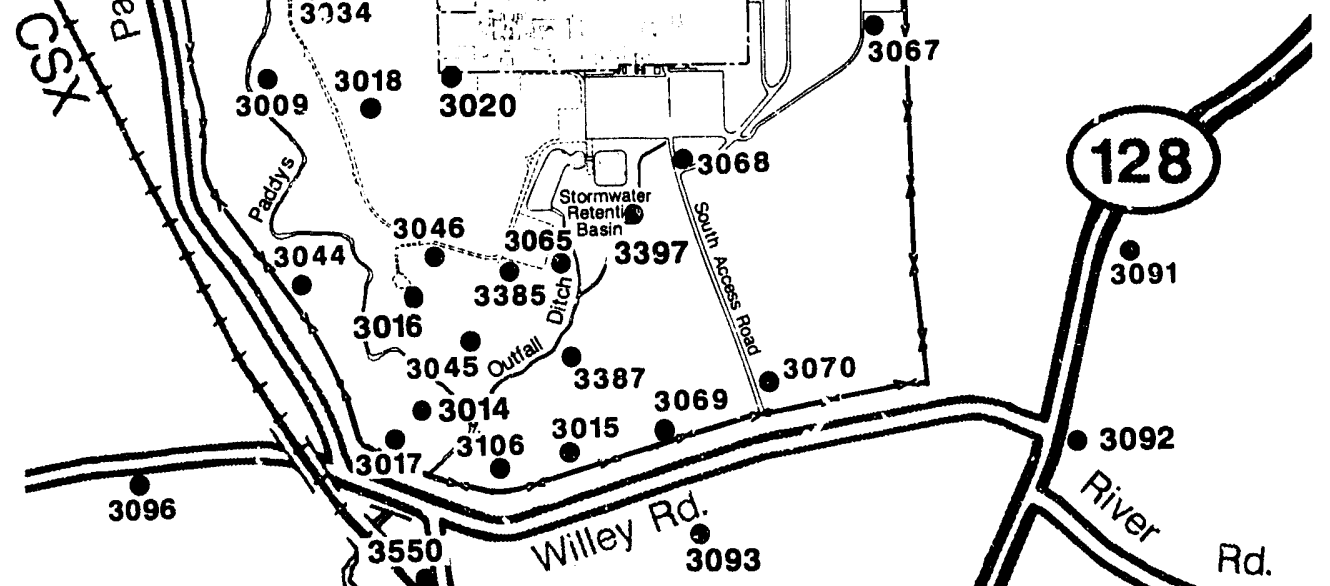

$$
=51
$$

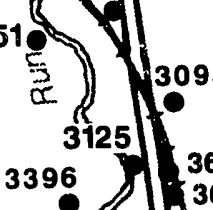

3689

us 3552

3062

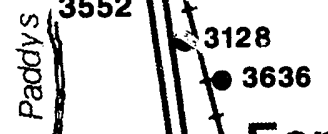

New Haven Rd.

\section{LEGEND}

3000 Saries Well

00000 Primary NDWS Detection $\triangle 0000$ Proposed USEPA Standard

Total U Detection

$\$ 0000$ Primary and Total U Detection 
Figure 44: 4000-Series Wells
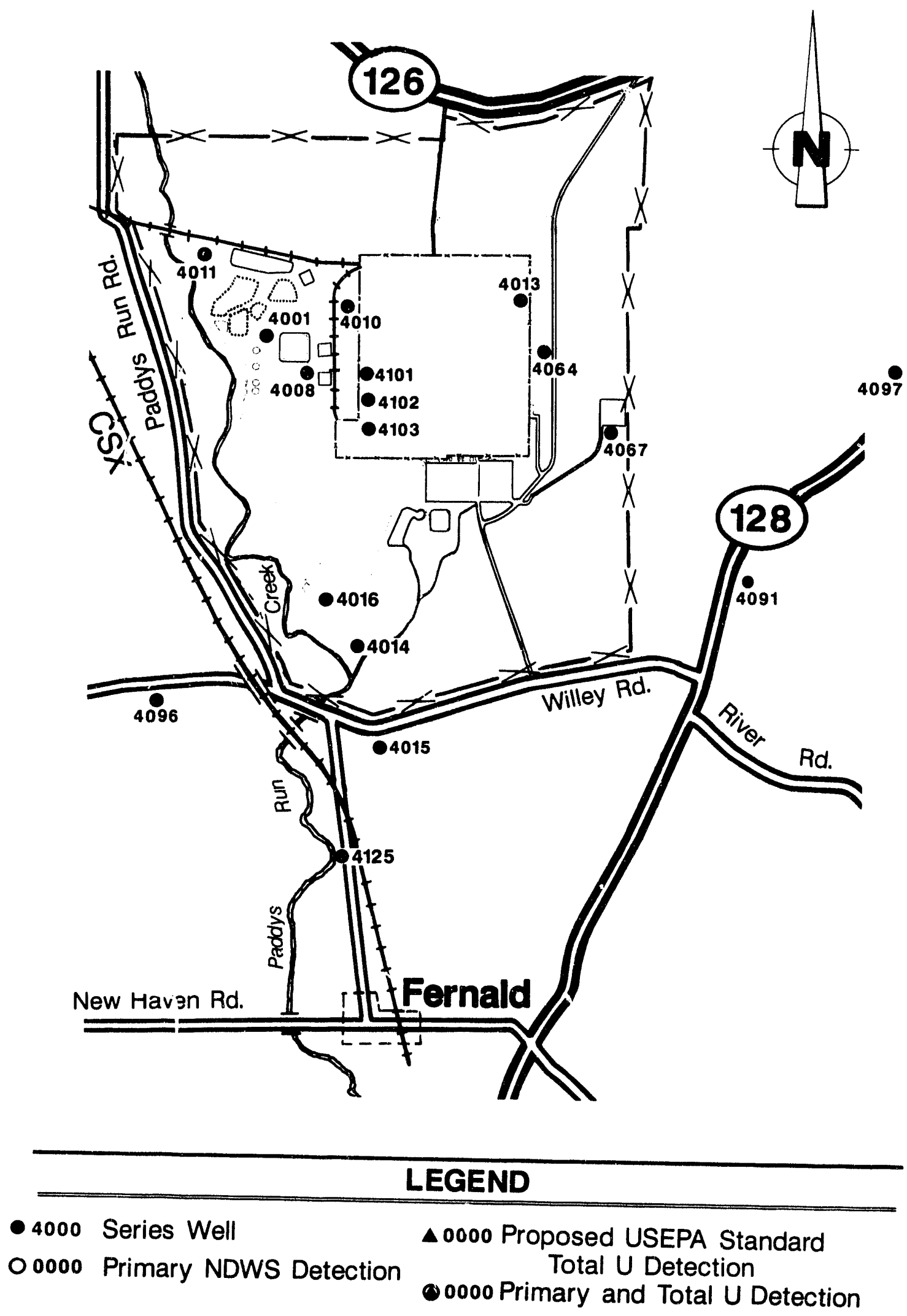
Nitrates were detected in nine wells in the waste pit area. The twenty detections ranged from 12 to $140 \mathrm{mg} / \mathrm{L}$, while the standard is set at $10 \mathrm{mg} / \mathrm{L}$.

Two wells in the silo area showed four detections of trichloroethene. While the standard is sut at $0.005 \mathrm{mg} / \mathrm{L}$, detections ranged from 0.015 to $0.028 \mathrm{mg} / \mathrm{L}$.

Finally, vinyl chloride, a volatile organic compound used in a variety of processes involving solvents, paints, and gasoline, showed two detections in one well located in the silo area. ${ }^{33}$ These detections were 0.0051 and $0.0065 \mathrm{mg} / \mathrm{L}$. Because the detection limit was greater than the $0.005 \mathrm{mg} / \mathrm{L}$ standard, additional wells may have exceeded the standard. The Fernald site is currently addressing this issue, and the information will be recorded in the 1993 report.

\section{Detections above Secondary Standards}

Several constituents were detected above their secondary standards in 1992. However, it should be noted that many of these secondary constituents are naturally occurring, and their presence does not pose a threat to human health or to the environment except at considerably higher concentrations. ${ }^{34}$

Iron and manganese are two particularly noteworthy examples of such naturally occurring elements. Both are commonly found at high levels in southwest Ohio. Iron was detected above its secondary standard at 73 on- and offsite wells, and manganese was detected above its standard at 75 wells.

Sulfate, one of the major anions in water, was found above its standard in 21 wells. Detections ranged from 254 to $532 \mathrm{mg} / \mathrm{L}$. This range can be compared to the standard set for sulfate which is $250 \mathrm{mg} / \mathrm{L}$.

Total dissolved solids, a measure which exceeded the secondary standard at 70 wells, is simply an indicator of the amount of solid matter dissolved in the water. In a region where certain specific constituents are naturally high, such as iron and manganese, it is common to have high levels of total dissolved solids.

\section{The RCRA Groundwater Assessment Program}

This subprogram has grown from 41 wells in 1987 to 77 wells by the end of 1992 . The Great Miami Aquifer is monitored by 46 wells, and 31 wells are in the glacial till. Results from these onsite wells are used to determine the rate and extent of contaminant migration in the vicinity of the waste pits.

The onsite RCRA Groundwater Assessment Program wells are not only monitored for drinking water standards, but they are also monitored for many additional RCRA parameters. Sampling in 1992 detected at least one site-specific parameter in 29 wells in the sand and gravel aquifer. Five of the 46 aquifer wells had increasing 
concentrations, with three of these wells being in the waste pit area. One well was at the southern boundary of the site, and the fifth well was located in the northwest sector of the site property. ${ }^{35}$ Complete results from this program are discussed in the 1992 RCRA Annual Report.

The Fernald site developed the RCRA Groundwater Monitoring Plan to integrate the requirement to provide groundwater monitoring for RCRA regulated units with CERCLA remedial investigation activities. This plan monitors for site-specific parameters at two waste management areas and the facility boundary. Results from these monitoring activities will allow site personnel to analyze and evaluate changes in water quality over time. Although this RCRA Groundwater Monitoring Plan has been implemented onsite, it has not yet been approved by OEPA.

Both the air and liquid pathways allow radioactive and non-radioactive materials to leave the Fernald site and are, therefore, monitored. The results from these monitoring activities are used to estimate potential radiation dose, which is discussed next in Chapter Seven. 


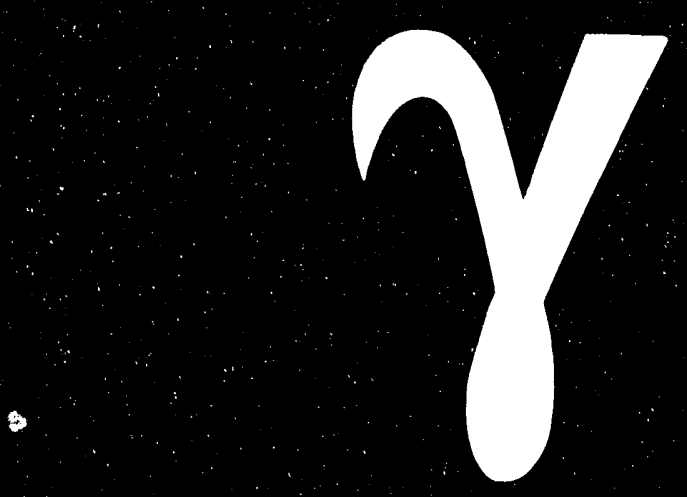




\title{
Estimated Radiation Doses for 1992
}

One of the chief public concerns about any facility that handles radioactive materials is that people working and living in the area may be exposed to harmful amounts of radiation. In response to this concern and environmental regulations, Fernald site personnel are monitoring the ways in which radioactive material could move through the environment and reach people. Background radiation levels and naturally occurring radioactive materials present technical as well as practical problems in trying to directly measure the dose people may actually receive from the Fernald site; therefore, scientists estimate dose using models and the results of environmental samples. This chapter:

- Explains how dose estimates are calculated,

- Provides 1992 dose estimates from several different pathways, and

- Interprets the significance of these estimated doses.

\section{Results in Brief 1992 Estimated Doses*}

\begin{abstract}
Nr Pathway
Airborne Emissions - The estimated maximum effective dose to a member of the public from 1992 airborne emissions was calculated as 0.2 mrem.

Foodstuffs - The committed effective dose from eating foodstuffs produced within three miles of the site was estimated to be $0.8 \mathrm{mrem}$.

Direct Radiation - There was no statistical difference between direct radiation measurements at the site fericeline and measurements at background locations. Therefore, no dose is attributed to direct radiation for 1992. This can be compared to the 8.8 mrem estimated for 1991 . The bentonite layer, added to the K-65 silos in late 1991, effectively shields and reduces the levels of direct radiation from the silos.
\end{abstract}

\section{Uquid Pathway}

Great Miami River - Although the river is not used as a source of public drinking water, the estimated committed effective dose from drinking river water down stream of the site effluent line was $0.02 \mathrm{mrem}$.

Fish - The estimated committed effective dose from eating fish from the river near the Fernald site effluent line was 0.01 mrem.

* These doses for 1992 are also presented in Table 22 on page A-36. Information on doses received from other sources is also provided in that table. 


\section{Methodology for Calculating Total Radiation Dose}

DOE Orders and USEPA regulations require the Fernald site to demonstrate that its radionuclide airborne emissions are low enough to ensure that no one in the public receives an effective dose of 10 mrem or more in any one year. (This excludes radon-222 emissions, which are covered under different regulations. Radon regulations, emissions, and estimated dose from radon are presented in Chapter Eight of this report.) Moreover, to determine whether the site is well within the DOE dose limit to members of the public of 100 mrem per year from all exposure pathways, Fernald site personnel estimate doses from other components of the air and liquid pathways, as well as direct radiation dose from materials stored onsite. The DOE limit of 100 mrem per year from all pathways is the sum of the doses from radiation external to the body during the year plus the dose from radionuclides taken into the body during the year. This latter dose is called the committed effective dose and is rect." "ed over a 50-year period.

As described in Chapter One, pathways are the routes along which radioactive material moves and may deliver a dose to the public. Total dose estimates incorporate dose from the air and liquid pathways. Direct radiation is included as a component of the air pathway dose. Monitoring of the air and liquid pathways provide the basis for the extensive environmental sampling described in chapters Four, Five, and Six. Using these measurements, a dose from each pathway can be estimated using models.

\section{Environmental and Dose Modeling}

The Fernald site, like many other nuclear facilities, uses models to estimate doses to the public. Models play an important role in environmental monitoring because current technology and the low concentrations of radioactive pollutants in the environment make it impractical to measure environmental doses with standard instruments. The nature of radioactivity and the presence of naturally occurring radioactive materials create difficulties in detecting low levels of radioactivity and distinguishing between natural radioactivity and radioactivity from the Fernald site. Models also estimate pollutant concentrations and doses which are below the detection capabilities of instruments and laboratory measurements. These concentrations and doses would be left out in assessing the environmental impacts of the site if models were not used. Environmental and dose models are briefly explained below.

Environmental modeling is a way to represent a complex environmental process, such as atmospheric dispersion of emissions or the air-to-soil-to-produce process, as a set of mathematical formulas. By studying an environmental process, such as dispersion of a pollutant from a stack as it is carried by the wind, scientists can develop a mathematical formula that models the process. They can then use this model to predict the concentration of the pollutant at a specific location. As additional processes are modeled, it is possible to interconnect them so that the movement of pollutants is predicted by a larger environmental model. 
Dose models are developed similarly. By modeling radioactive decay, absorption and removal of radioactive materials in the body, and other physical and biological processes, scientists can develop a dose model to evaluate how radioactive materials deliver a dose. Connecting the dose model to the environmental model provides a means of estimating dose using information gathered through environmental sampling. Models are usually translated into computer programs to conveniently handle the data and calculations.

Although models may be the only comparative way for scientists to estimate dose, they do not necessarily predict all environmental processes. Since the mathematical formulas that represent the environmental and biological processes are simplifications and generalizations, applying them to the specific conditions at the site may lead to differences between predicted and actual concentrations or doses. The results or outputs of models always involve some uncertainty in the accuracy of the estimated dose, and many have built-in assumptions which strongly influence the results. Models may be most beneficial because of their ability to estimate the upper limit of the dose and identify the most influential pollutant or pathway of exposure.

\section{Air Pathway Dose Calculations}

The air pathway is a route for contaminants to reach people directly as emissions and indirectly through foods contaminated by airborne emissions. This section uses data from air and produce sampling as well as estimates of airborne releases (refer to Chapter Four) to calculate doses. Dose from radon is presented in the following chapter of this report.

\section{Estimated Doses from Airborne Emissions}

At the Fernald site, scientists obtain dose estimates from airborne emissions using a set of computer programs called CAP-88. The site used CAP- 88 to determine compliance with the NESHAP requirements of the Clean Air Act. Within the CAP- 88 set of programs, the AIRDOS program calculates concentrations of radionuclides in the air, on the ground, and in food based on estimates of the amount of airborne radioactive material released. The concentrations are then used to calculate the intakes and subsequent doses to people.

The CAP-88 computer programs calculate both individual and collective doses. Collective dose is the sum of individual doses to people in the Fernald area and is reported in the units of person-rem. (For example, if 10 people each receive 1 rem, the collective dose is " 10 person-rem;" if 20 people each receive $0.5 \mathrm{rem}$, that collective dose also is " 10 person-rem.") The per?on-rem unit is used as a broad measure of the radiological impacts of the site and is useful in comparing the risks from site operations with other facilities and industries. 
The CAP-88 programs require a large amount of data to estimate dose, which includes the number, height, and location of release points, wind speed and direction, the amount of radioactive material released, and population distribution in the Fernald area. (Wind rose data are shown in Figures 7 and 8 in Chapter One, and estimated airborne radionuclide emissions and population distribution are presented in tables 2 and 23 on pages A-3 and A-37 respectively.) Although some of the data were obtained through measurements and sampling, many data were not readily available and were estimated. Examples of estimated data are the amounts of airborne radioactive material released from the waste pits, Laboratory Building, and Water Cooling Towers. The site made very conservative estimates for these and all other emission sources which were not measured directly. Conservative estimates, used frequently in environmental monitoring and dose calculations, are based on assumptions about an exposure situation that should result in the highest estimate of a dose. For example, an assumption about estimated doses at the air monitoring stations is that a person is outdoors at one location for $100 \%$ of the time during the year. The assumptions are conservative in the sense that they provide a margin of error for underestimating emissions and doses. Conservative estimates of emissions are used to ensure that dose estimates are not underestimated but are the maximum doses that could have resulted from site operations during 1992.

Figure 45: Department of Energy Dose Limits

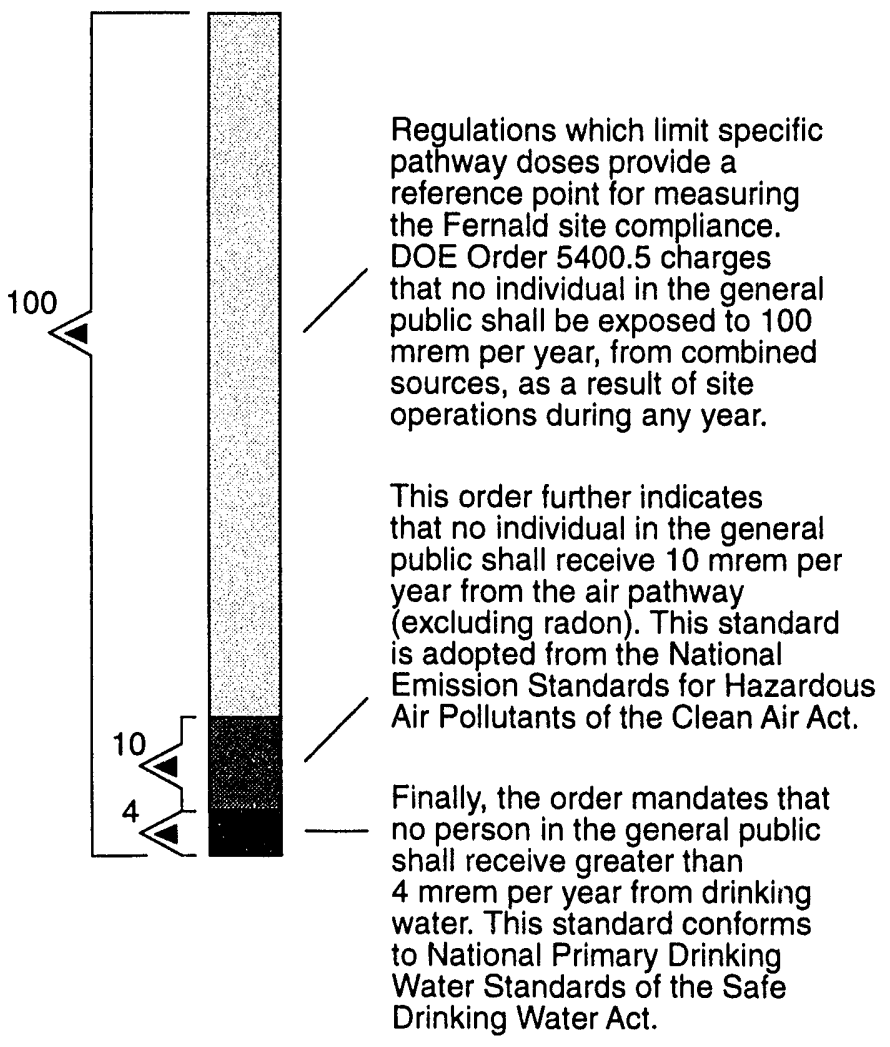

Results of the CAP-88 programs estimated the maximum effective dose from 1992 airborne emissions to be $0.2 \mathrm{mrem}$ to a person located north of the former production area. This dose estimate assumed that the person remained outside his or her home $100 \%$ of the time in 1992. The dose was well below the NESHAP standard of $10 \mathrm{mrem}$ from the air pathway and was only $0.2 \%$ of the DOE guideline of 100 mrem per year from all pathways (see Figure 45).

The collective effective dose from 1992 airborne emissions (not including radon) to the population within $80 \mathrm{~km}$ (50 miles) of the site was also calculated by CAP- 88 . This dose was estimated to be 1.3 person-rem for a population of $2,740,000$. For comparison, the same group of people received an estimated collective effective dose of 274,000 person-rem from background radiation, excluding radon. 


\section{Estimated Dose from Eating Foodstuffs Produced near the Fernald Site}

Since the CAP-88 program only calculated doses from 1992 airborne emissions, scientists made additional dose calculations to estimate doses from past emissions that may have accumulated through the food chain. These additional calculations estimate potential dose from consuming locally grown fruits, vegetables, and milk.

Uranium deposited in soil during the years the Fernald site was in production may be absorbed by produce and farm animals and, therefore, deliver a secondary pathway dose. This estimated dose is based on the conservative assumption that $100 \%$ of a person's diet of fruit, vegetables, and milk comes from gardens and farms in the Fernald area. This modeled diet assumes an annual consumption of $18 \mathrm{~kg}$ (40 pounds) of leafy vegetables (cabbage, lettuce, etc.), $45 \mathrm{~kg}$ (100 pounds) of grains (corn, soy beans, wheat, etc.), $68 \mathrm{~kg}$ (150 pounds) of fruit, $28 \mathrm{~kg}$ (62 pounds) of below ground vegetables (potatoes, carrots, etc.), $45 \mathrm{~kg}$ (100 pounds) of other vegetables, and 112 liters (30 gallons) of milk. ${ }^{36}$ Scientists analyzed cabbage, corn, soybeans, apples, potatoes, tomatoes, beans, and milk sampled from local gardens and farms for uranium to represent the foods in the diet. The maximum uranium concentration found in locally produced foods was used to estimate dose. The average background uranium concentration in foods was subtracted from the maximum concentration to account for the natural occurrence of uranium in foods.

The laboratory analysis of foodstuffs determines the total amount of uranium (all uranium isotopes) in the sample. Because any dose from uranium is based on the isotopic composition of uranium, an assumption about the isotopic composition of uranium in foodstuffs must be made to calculate the dose. Scientists assume any uranium detected in the foodstuffs has the isotopic composition of natural uranium. This assumption is reasonable because a large amount of uranium produced at the Fernald site had an isotopic composition similar to naturally occurring uranium. Scientists used dose conversion factors to convert the intake of uranium to dose. The conversion factors themselves are the result of modeling the radioactive decay and metabolism of radionuclides in the body. ${ }^{37}$

The committed effective dose received over the course of 50 years was calculated to be $0.8 \mathrm{mrem}$, only $0.8 \%$ of the DOE dose limit of 100 mrem per year for all pathways. This dose is comparable to the estimated doses from foodstuffs in past years. It is worth noting that the conservative assumptions used in calculating dose lead to a small dose from tomatoes and corn. This occurs even though uranium concentrations in local tomatoes and corn were not statistically higher than concentrations in tomatoes and corn grown at background locations (see Chapter Four). This is an example of how the conservative assumptions used in estimating dose can lead to a reported dose which is not firmly supported by all environmental data. 


\section{Direct Radiation Dose}

Unlike the air and liquid pathways where a radionuclide in the form of a particulate or gas delivers its dose after inhalation or ingestion, direct radiation dose is the result of radiation (gamma and X-rays) emitted from radionuclides stored onsite. The largest sources of direct radiation are the wastes stored in the K-65 silos and thorium compounds stored at several locations onsite. Direct radiation dose is estimated using environmental TLD measurements (see Chapter Four), rather than estimated through the use of models.

Direct radiation dose was estimated using the highest dose from a fenceline monitoring location and subtracting the average dose measured at four background TLD locations (locations 18, 19, 20, and 21 as shown in Figure 27 on page 76). Limits in the accuracy of TLD measurements require consideration of the plus/minus $( \pm)$ values associated with each measurement in calculating dose.

Location 2 had the highest dose, $70 \pm 12$ mrem per year (two sigma), of the TLD locations along the site fenceline. The average background dose was $58 \pm 14 \mathrm{mrem}$ per year. At first glance, it appears that the fenceline dose is 12 mrem per year higher than the background dose. However, when the accuracy of the measurements is taken into account, there is no statistical difference in the two doses. To understand this, consider the difference between the combined uncertainty of the two dose measurements. The difference is calculated to be 12 mrem per year, but the combined uncertainty associated with this difference is \pm 18 mrem per year. Since the 12 mrem difference in doses is exceeded by the uncertainty term, the $\pm 18 \mathrm{mrem}$, there is no firm basis for stating that there is a statistical difference between the two measurements.

Given this lack of statistical difference between fenceline and background measurements, no dose is attributed to direct radiation for 1992. This is a significant reduction from the 8.8 mrem estimated for 1991 . The bentonite layer, added to the K-65 silos in late 1991, effectively shields and reduces the levels of direct radiation from the silos. 


\section{Liquid Pathway Dose Calculations}

Dose estimates from the liquid pathway are calculated using environmental sample results and dose conversion factors. Measurements of radionuclide concentrations in groundwater, the Great Miami River, and fish from the river are used to estimate dose from the liquid pathway. Descriptions of the monitoring programs for these environmental samples are given in chapters Five and Six.

\section{Estimated Background Dose from Drinking Well Water in the Area around the Fernald Site}

As discussed in Chapter Six, the site monitors a number of private wells which have uranium concentrations within the range of background levels. In the Fernald area, the range of background concentrations is 0.07 to $2.0 \mathrm{pCi} / \mathrm{L}$ ( 0.1 to 3.0 parts per billion). To provide additional information on the amount of dose received from naturally occurring uranium in well water, the site estimated the dose received from this range of background concentrations. For purposes of the dose calculation, uranium in well water is assumed to have the isotopic composition of natural uranium.

Using a consumption rate of 2 liters ( 0.5 gallon) of water per day, the committed effective dose received over the course of 50 years would range between 0.01 mrem and $0.4 \mathrm{mrem}$. The actual dose received would depend on the concentration present in the private well. This range of background doses is useful information in developing a perspective for evaluating the small, incremental dose attributable to site emissions.

Figure 46: Great Miami River Dose

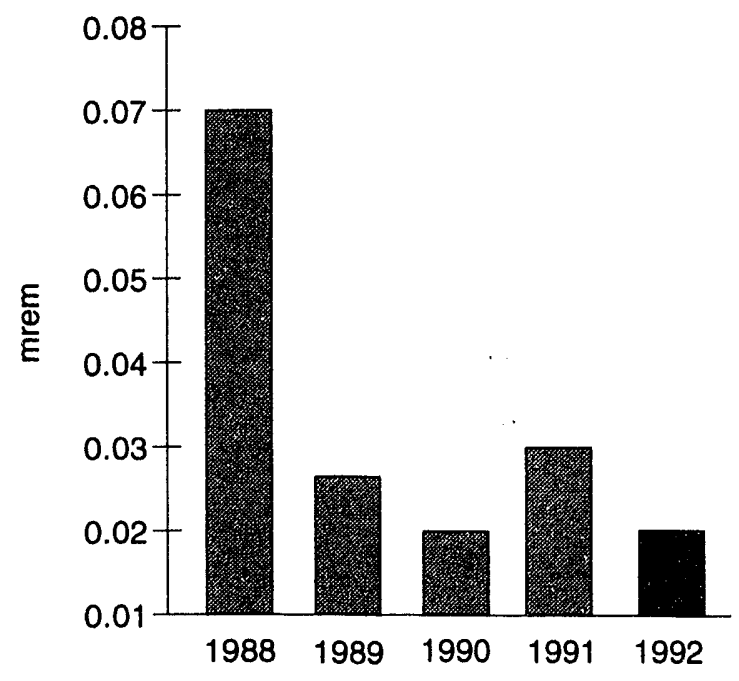

\section{Estimated Dose from Drinking Great Miami River Water}

Although the Great Miami River downstream of the site is not designated as a public water supply by OEPA, the site estimated the radiation dose to an individual if that person drank only the water from the river downstream of the discharge point after mixing had occurred.

Scientists used data on the amounts of radionuclides discharged to the Great Miami River (see Table 16 on page A-26) and the average river flow to calculate concentrations in river water. Dose conversion factors were used to convert the intake of radionuclides to dose. Assuming a daily consumption of 2 liters $(0.5$ gallon) of water, the committed effective dose received over the course of 50 years would be $0.02 \mathrm{mrem}$ (see Figure 46). ${ }^{36}$ 


\section{Estimated Dose from Eating Fish from the Great Miami River}

The estimated dose from eating fish from the river was calculated using the maximum uranium concentration in edible fish collected at sites 2, 3, and 4 (see Figure 35 on page 92). The average background uranium concentration in edible fish collected at Site 1 was subtracted from the maximum concentration to account for natural occurrence of uranium in the fish. As with other dose calculations, any uranium detected in the fish was assumed to have the isotopic composition of natural uranium.

Assuming an annual consumption of $4.5 \mathrm{~kg}$ (10 pounds) of fish from the Great Miami River, the committed effective dose would be less than $0.01 \mathrm{mrem} .{ }^{36}$ This dose is well below the DOE guideline of 100 mrem effective dose per year from all pathways.

\section{Total of Doses to a Maximally Exposed Individual}

The maximally exposed individual is a hypothetical member of the public who receives the highest calculated effective dose based on the location of his or her home, weather conditions, and the individual pathway doses. Since it is not possible to single out a specific individual in the Fernald area who receives the most dose, the results of the individual pathways and the CAP- 88 evaluation are added to predict the maximum dose that a person could receive. The dose to the maximally exposed individual is a total of estimated doses from breathing 1992 airborne emissions (excluding radon), consuming foodstuffs produced in the Fernald area, drinking water from the Great Miami River (even though the river is not a source of drinking water south of the site), eating fish from the Great Miami River, and the direct radiation dose at the home nearest the K-65 silos. The conservative assumptions used throughout the dose calculation process ensure that the dose to the maximally exposed individual is the upper limit of the actual dose any member of the public receives.

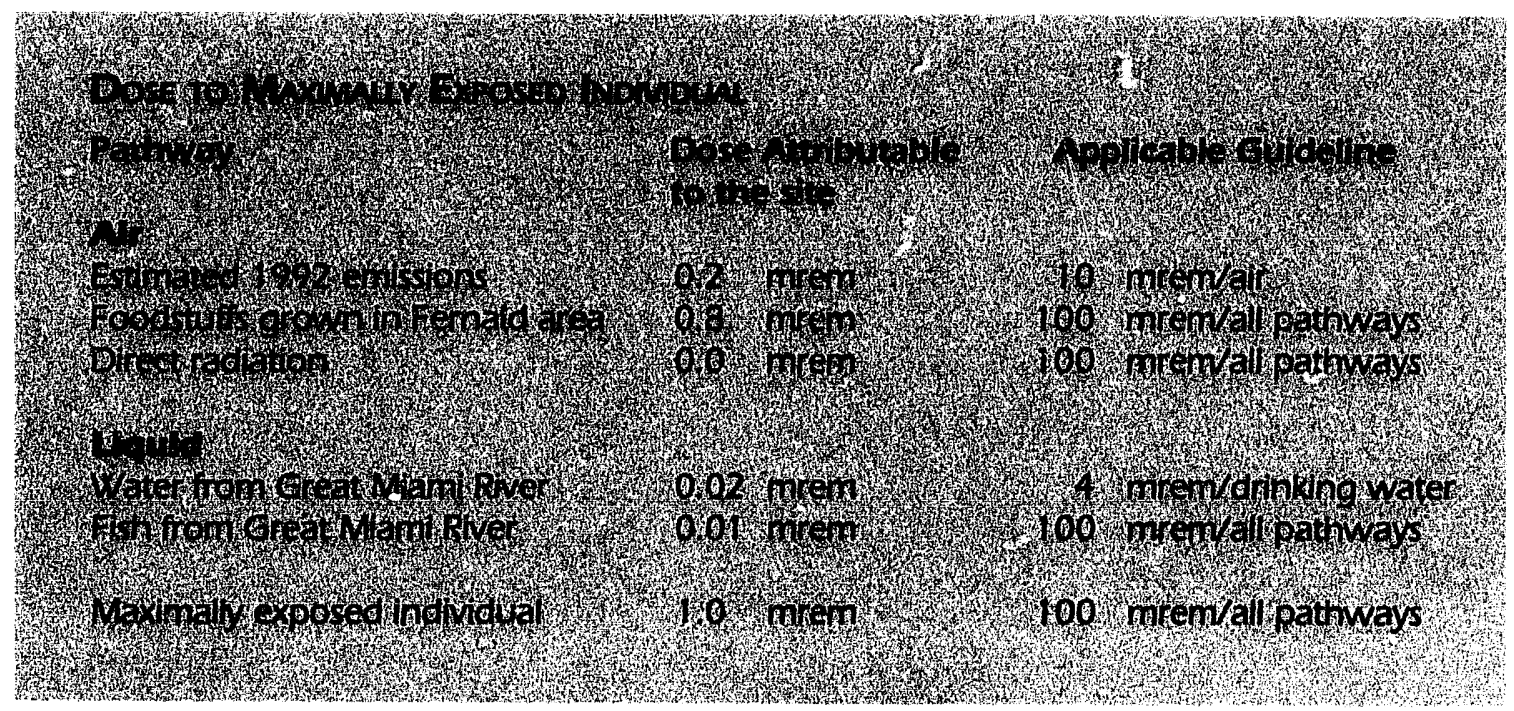


The dose to the maximally exposed individual is estimated to be $1.0 \mathrm{mrem}$, well below the guideline of 100 mrem per year for all pathways. The 1.0 mrem dose represents a $90 \%$ decrease from the maximally exposed individual dose for 1991 . The decrease is largely due to the lower direct radiation dose which is attributed to the shielding provided by the addition of the bentonite to the K-65 silos in November 1991 .

\section{Significance of Estimated Radiation Doses for 1992}

One method of evaluating the significance of the estimated doses is to compare them with doses received from background radiation (see Chapter Two). Background radiation yields approximately 100 mrem per year from natural sources, excluding radon. Comparing the maximally exposed individual dose to the background dose demonstrates that, even with the conservative estimates, the dose from the site is much less than background. Although the estimated dose will be received in addition to the background dose, this comparison provides a basis for evaluating the significance of the estimated doses. A dose that is small in comparison to that of background radiation will produce no measurable health effects.

Another method of determining the significance of the estimated doses is to compare them with dose limits developed to protect the public. The International Commission on Radiological Protection (ICRP) has recommended that members of the public receive no more than 100 mrem per year as a result of site operations, and DOE has incorporated this limit into Order 5400.5 as well. The sum of all estimated doses from site operations for 1992 was well within this limit.

Radon is subject to different regulations than other components of the air pathway. Likewise, the dose received from radon is regulated separately. Therefore, the Radon Monitoring Program is discussed separately in the next chapter, as well as the dose received from radon at the Fernald site. 


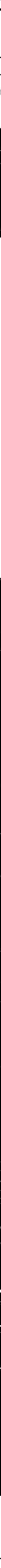

Sitewide CERCL 


\section{The Radon Monitoring Program}

Radon is a radioactive gas that occurs naturally throughout the environment. Everyone is exposed to radon at varying concentrations, and exposure to ra don is part of the annual background radiation dose that people receive. As discussed in Chapter Two, this exposure contributes approximately 55\% to a person's average annual dose.

In addition to the radon found naturally in the environment, the Fernald site stores some materials onsite that decay to form radon. Because thiese materials are onsite, the Radon Monitoring Program has monitored radon levels onsite since the early $1980 \mathrm{~s}$. This program operates in compliance with the requirements of DOE Order 5400.5, "Radiation Protection of the Public and the Environment." Radon monitoring results and attributable dose are reported separately from the air pathway in order to improve the presentation of information and regulations that are unique to radon.

\section{Results in Brief: 1992 Radon Monitoring}

Fenceline - Average fenceline concentrations measured in 1992 were $0.57 \pm$ $0.29 \mathrm{pCi} / \mathrm{L}$ much lower than the DOE guideline of $3.0 \mathrm{pCi} / \mathrm{L}$ This represents a $37 \%$ decrease from 1991 fenceline concentrations.

Background - The average background concentration for 1992 was $0.40 \pm 0.13$ $\mathrm{pCi} / \mathrm{L}$. This concentration is $32 \%$ lower than the $0.59 \pm 0.05 \mathrm{pCi} / \mathrm{L}$ reported in 1991. Background radon concentrations can vary considerably from year to year.

Net Concentration at Fenceline - These concentrations show the average amount attributable to the Femald site (fenceline concentration minus the background concentration). In 1992, this concentration was $0.17 \pm 0.33 \mathrm{pCV} / \mathrm{L}$ a $45 \%$ decrease from the 1991 average net concentration.

Dose Received from Radon - The effective dose is calculated from the 0.17 pCi $/ \mathrm{L}$ average net concentration at the fenceline. In 1992, this dose was $51 \mathrm{mrem}$, $45 \%$ lower than in 1991. This dose is in addition to the dose received from background levels of radon (approximately 200 mrem per year). 


\section{Introduction to Radon}

Three isotopes of radon are found in the environment. They are a part of the uranium238 , thorium-232, and uranium-235 (actinium) decay series. These decay series or chains are formed by a series of natural radioactive decays, with many individual isotopes having extremely long half-lives. Radon-219 (actinon) is the seventh decay product in the actinium decay chain. Radon-220 (thoron) is the fifth decay product in the thorium decay chain. Radon-222 (radon) is the sixth decay product from the uranium-238 decay chain. These decay chains are shown in Figure 47.

Of minor importance is radon-219, due to its 3.96 second half-life and the fact that it comes from uranium-235, which has a very low natural distribution in the environment. Radon-220, with a much longer half-life of 55.6 seconds, can be a significant contributor to the potential radiation dose to people. This occurs primarily in geographic regions that have shallow deposits of thorium-rich soils. Although the area on which the Fernald site is located does not contain thorium-rich soils, technicians

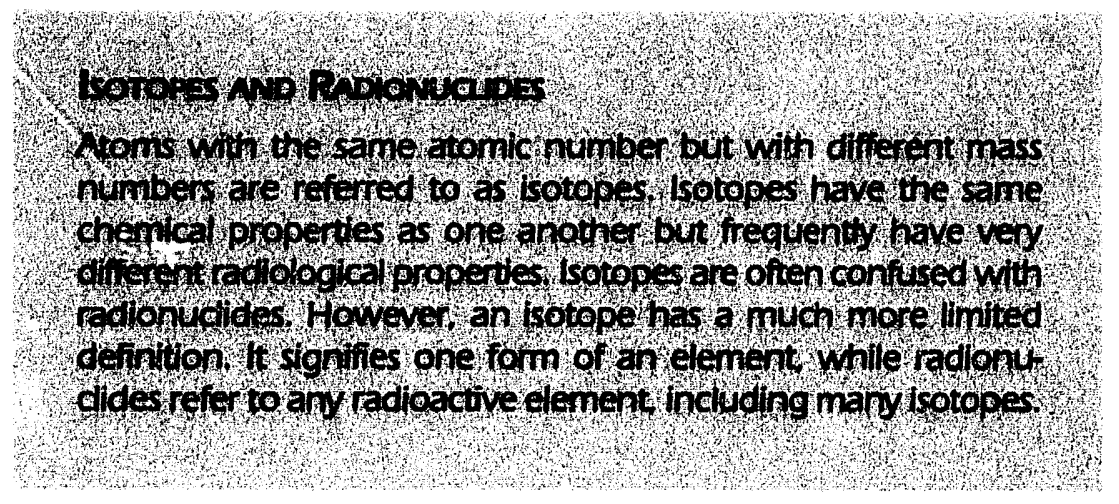

monitor for radon- 220 because thorium compounds have been stored at the site since the early 1970s. At one time, the site studied possible uses for thorium and had processed the material for use at other government facilities.

Radon-222 is a naturally occurring decay product of uranium-238 which is widespread in the earth's crust. Radon-222 has the longest half-life of the radon isotopes, 3.8 days, and it gives rise to the majority of the concern for risks from radon exposure. Therefore, the general term radon refers to this isotope. Radon-222 is virtually everywhere because of the widespread distribution of its parent radionuclides, radium-226 and uranium-238, in the earth's crust.

Radon decays into a series of short-lived radionuclides that are collectively referred to as radon "daughters," or redon decay products. Some of these short-lived daughters emit alpha particles. As alpha particles are easily shielded by the skin, the primary concern of radon exposure is the internal dose received by inhalation. When these radon daughters are inhaled and alpha particles are released within the lungs, the cells lining the airways may be damaged and lung cancer may ultimately result. This dose is attributed to the radon daughters. 
Figure 47: Decay Chains
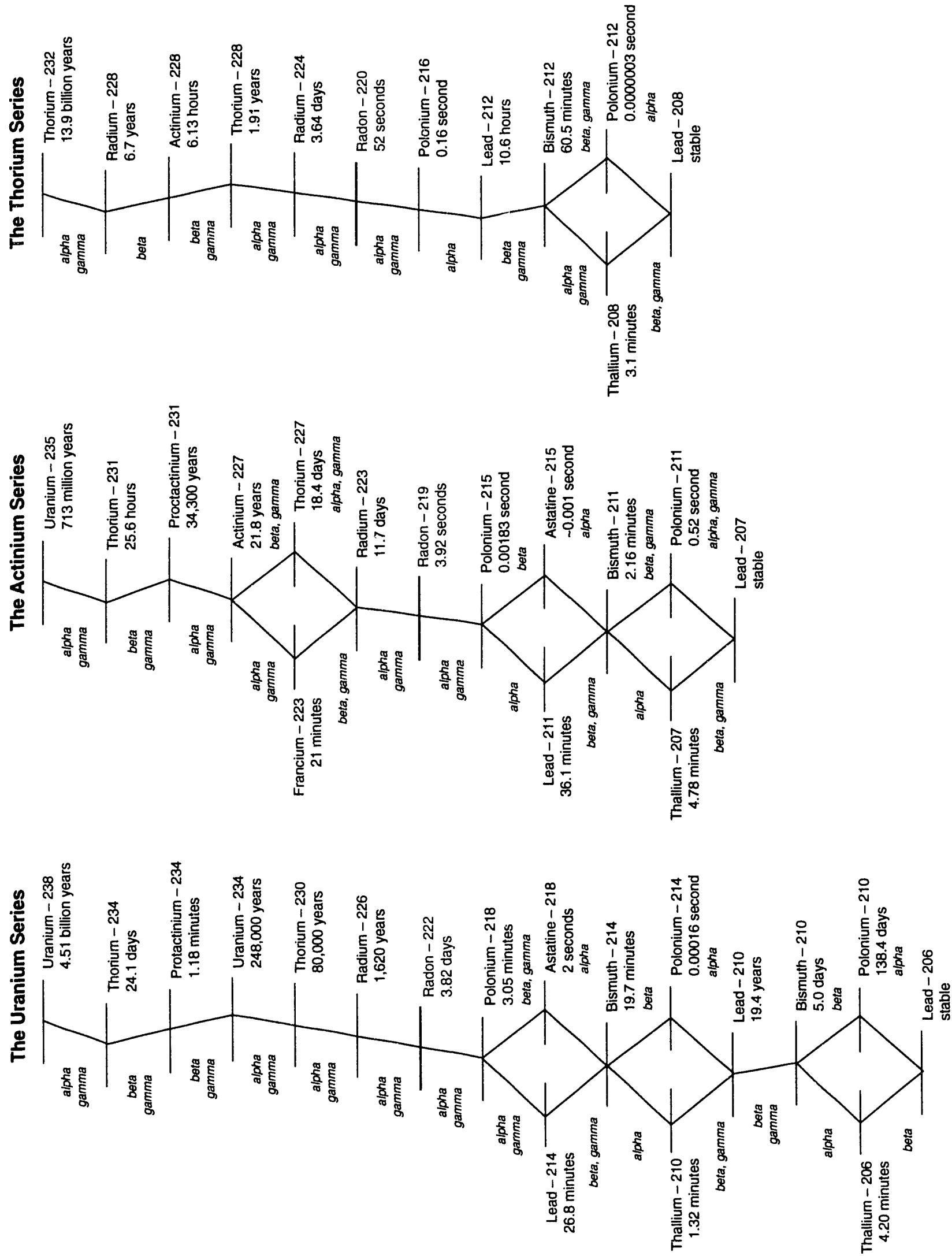


\section{Radon in the Environment}

Radon's importance as a source of background radiation depends principally on three factors: the concentration of its parent material, the physical characteristics of the rocks and soil, and its half-life. The amount of parent material in the area is a significant factor in determining the amount of radon found there. The last two factors determine its ability to migrate into air and water. The relatively short half-life of radon allows some media to become an effective filter barrier.

Some of the radon produced by radium decay escapes into the air spaces around soil particles and then diffuses into the atmosphere. Consequently, radon is always present in outdoor air and is a source of background radiation. The concentration of radon will depend on the local environment and soil characteristics.

The outdoor concentration of radon in the atmosphere shows daily and seasonal patterns. These changes are caused, in part, by atmospheric conditions. They are also caused by changes in the rate that radon is released from the ground because of precipitation and freezing temperatures. Because radon tends to accumulate under stagnant weather conditions, concentrations increase during periods of calm winds and temperature inversions. (During temperature inversions, warm air traps cooler air near the earth's surface and prevents mixing and turbulence of the air near the surface. When these inversions occur, radon is also trapped near the earth's surface.)

\section{Radon at the Fernald Site}

In addition to the radon formed naturally in the environment, the Fernald site stores some materials onsite which are parent materials of radon. It is believed that the principal source of radon emissions from the site is currently the $K-65$ silos because of their radon-emitting ore residues. Radon can escape through the cracks and access ports on top of the $\mathrm{K}-65$ silos. To ensure that radon emissions are monitored as efficiently as possible, radon concentration measurements are taken in the air at points immediately adjacent to the silos and at points on the fenceline, as well as in the headspace of the silos themselves. In November 1991, a bentonite sealant was placed over the residues to reduce the amount of radon emitted into the headspace. This removal action has decreased the emissions, as will be discussed later.

The waste pits are potential sources of radon because they contain radium-226, the parent material for radon-222. Radon-222 emissions were measured at Waste Pits 1, 2, and 3 in 1991 and were found to be well below the regulatory limit. Waste Pit 4, another potential source of radon emission, was capped and covered with a hypalon layer as part of the RCRA interim closure of that pit. Waste Pit 4 was monitored in 1992 pursuant to an agreement with USEPA. The emissions from that pit were also found to be well below the regulatory limit. Waste Pit 5 is a potential source of radon emissions when it is not covered with water. A CERCLA removal action has provided a water cover over all of Pit 5 , thereby eliminating any radon emissions from the pit to the atmosphere. (Waste Pit 6 is not considered a source of radon since very few radium-bearing materials are contained in it.) 


\section{Radon Monitoring at the Fernald Site}

It is DOE's objective to operate its facilities and conduct its activities so that radiation exposures to members of the public are As Low As Reasonably Achievable (ALARA). Therefore, DOE facilities monitor all releases applicable to site activities and also assess radiation exposures to members of the public. Aside from providing protection to members of the public, it is DOE's objective to protect the environment from radioactive contamination.

Since the site still stores radium-bearing materials onsite, radon concentrations in the atmosphere above facility surfaces or openings are regulated by DOE Order 5400.5, "Radiation Protection of the Public and the Environment." This order presents radiological protection requiremerits and guidelines for cleanup of residual radioactive material and the management of resulting wastes and residues and the radiological release of property. These requirements and guidelines are applicable at the time the property is released. Because these radium-bearing materials are onsite, the Radon Monitoring Program operates under these guidelines. When added to background levels, these concentrations must not exceed the following limits:

- $100 \mathrm{pCi} / \mathrm{L}$ at any given point,

- An annual average concentration of $30 \mathrm{pCi} / \mathrm{L}$ over the facility site,

- An annual average concentration of $3 \mathrm{pCi} / \mathrm{L}$ at or above any location outside the facility site, or

- Flux rates greater than $20 \mathrm{pCi} / \mathrm{m}^{2}$ per second from the storage of radon producing wastes.

NESHAP subpart $Q$ also has a flux-rate requirement but will not be applicable as a requirement until on-going remedial actions have been conducted and the final remedial action to abate the radon emission problem has taken place. These actions are conducted in compliance with the requirements of the Federal Facility Compliance Agreement/Federal Facility Agreement (FFCA/FFA). Therefore, all actions related to the control and abatement of radon-222 at the Fernald site are performed in cooperation with USEPA.

\section{Methodologies}

To determine radon concentrations in the environment, technicians use two types of detectors to monitor the alpha particles that are produced as radon gas decays: alpha-track etch detectors and real-time scintillation detectors.

An alpha-track etch detector is a cup that contains a special plastic chip inside. When alpha particles from radon (or its daughter products) interact with certain types of plastic, they will leave latent tracks in the material. The tracks can be made detectable by chemical or electrochemical etching. The number of etches or tracks in the material is equal to the number of alpha particles that have reached the plastic. This number can then be related to the average concentration of radon in the cup. 
Filters are placed over the cup to allow only radon to enter the cup and be measured. All environmental radon data presented in this 1992 report are from the alpha track-etch radon detectors, and select pertinent environmental data can be found in Table 24 on page A-38. Technicians change these detectors every three months to provide long-term radon measurements.

Environmental monitoring personnel obtain data from 21 locations at the site boundary using alpha track-etch monitoring cups, as well as from three area residences and four background locations (see Figure 48). The alpha track-etch monitoring cups are also used for measurement adjacent to the silos and in the predominant wind direction from them.

In 1992, the site used the same four locations as in 1991 to determine the background radon level. The background locations are shown as air monitoring stations 15 and 16 and background locations 1 and 2 in Figure 48.

Real-time monitors, which record radon concentrations on an hourly basis, detect alpha particles from the decay of radon gas by using a scintillation cell. These monitors provide an immediate readout of radon concentrations in the air or in the silo headspace. When monitoring the ambient outside air, air is not pulled into the monitor. Rather, the air diffuses into the monitor through a foam barrier (a technique called passive sampling); any radon gas present in the diffused air decays into its daughter products, some of which are alpha particle emitters. When monitoring the silo headspace air, air is pulled into a special cell. In both cases, the emitted alpha particles strike the alpha sensitive scintillator which lines the cell interior, producing light pulses. These light pulses are amplified and then counted. It takes about a half-hour to achieve the same radon gas level inside the cell as is present in the surrounding air. The locations of these monitors are shown in Figure 49 on page 130.

\section{Radon Monitoring Results}

Over the years, the Radon Monitoring Program has increased the number of detectors used at each monitoring location to gather more representative data. Increasing the number of cups at each location ensures more accurate data by reducing the error associated with only using one cup for a measurement.

During 1992, onsite radon concentrations in the vicinity of the silos never exceeded the $100 \mathrm{pCi} / \mathrm{L}$ limit and were well below the limit. Since the addition of the bentonite layer, this limit has not been exceeded at these locations even during temperature inversions. Radon concentrations recorded near the silos have been reduced by approximately 80\% when compared to data from 1991.

Even though a bentonite sealant was added to the silos at the end of November 1991, the area near the silos had the highest annual average radon concentration of all locations measured. Radon measurements near the silos and in the silo headspace 
Figure 48: Offsite and Fenceline Radon Monitoring Locations

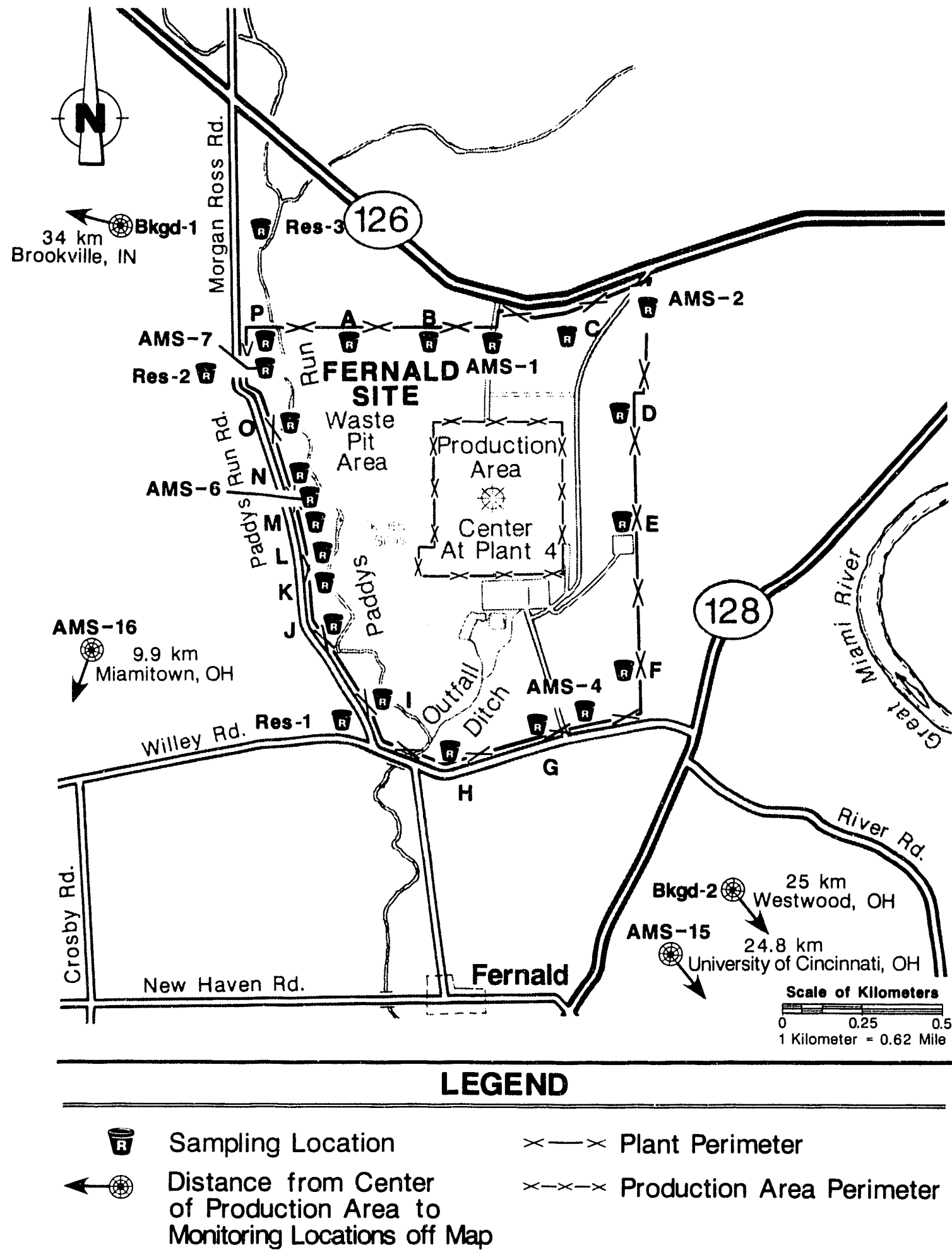

2011 
Figure 49: Real-Time Radon Monitoring Locations

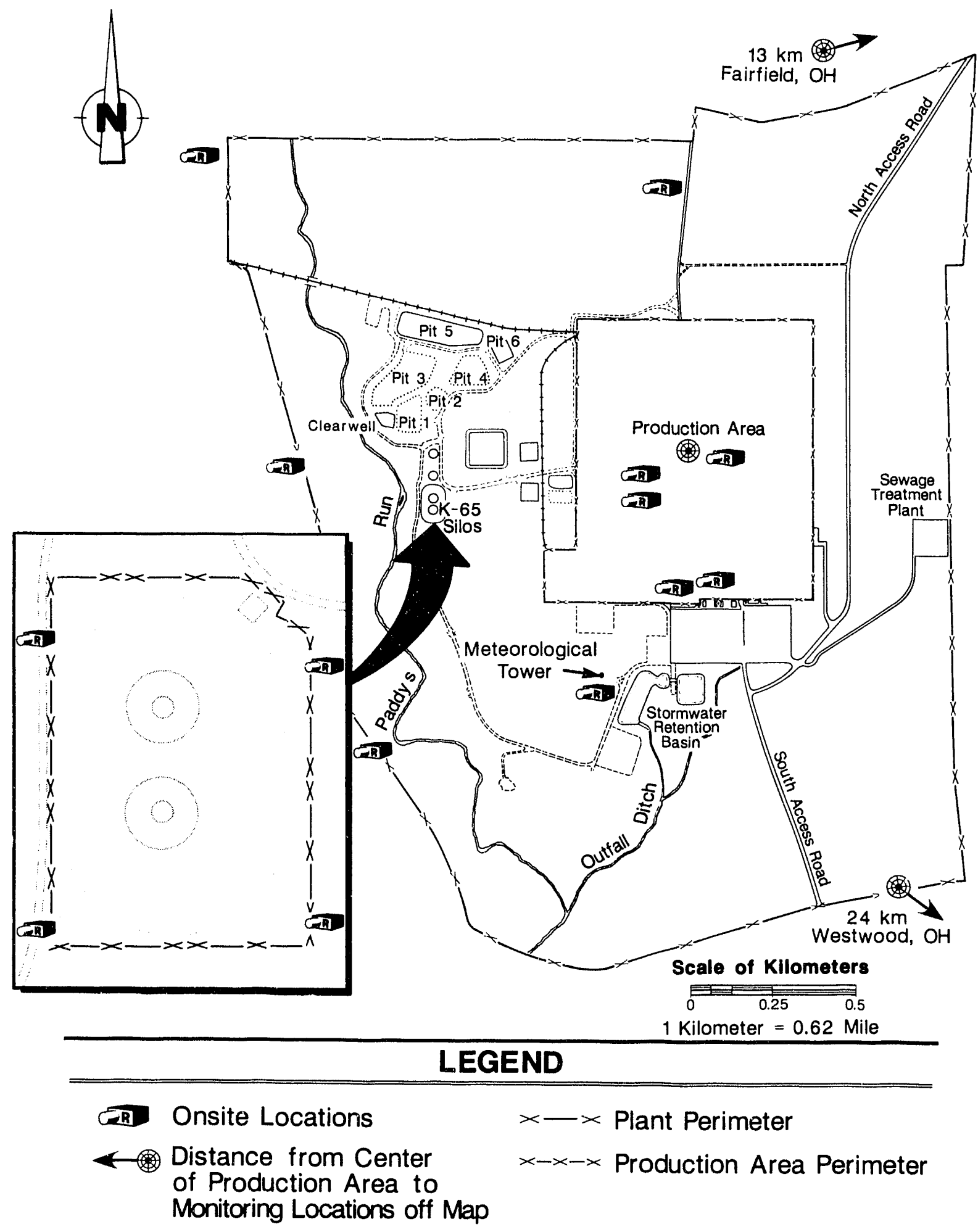


were monitored in 1992 to determine the effectiveness of the bentonite sealant. (Monitoring locations around the silos are shown in Figure 50 on the next page.) Silo headspace measurements were taken using real-time monitors. The average concentration at the silos including background was $0.7 \mathrm{pCi} / \mathrm{L}$, which is considerably less than the annual average limit of $30 \mathrm{pCi} / \mathrm{L}$. The average 1992 radon concentration, including background, for each of the 21 boundary locations was $0.57 \mathrm{pCi} / \mathrm{L}$, which is approximately $37 \%$ lower than in 1991.

In 1992, Waste Pit 4 was surveyed for a radon-flux measurement. The radon flux for this pit was less than $1 \mathrm{pCi} / \mathrm{m}^{2}$ per second. This measurement can be compared to the $20 \mathrm{pCi} / \mathrm{m}^{2}$ per second NESHAP flux limit.

\section{Estimated Radiation Dose from Radon}

To be certain that the calculated dose received from radon has not been underestimated, scientists use an assumption that ensures that the calculated dose is conservative (too high). That is, these scientists assume that a hypothetical person whose dose is being calculated breathed air at the fenceline continuously for an entire year. Radon daughter product concentrations were assumed to be equal to one-half the radon concentration, or $50 \%$ equilibrium (see below). For 1992, the estimated fenceline concentration, including background, was $0.57 \pm 0.29 \mathrm{pCi} / \mathrm{L}$, which is approximately $20 \%$ of the $\mathrm{DOE}$ guideline $(3.0 \mathrm{pCi} / \mathrm{L})$ at the perimeter of the facility. Using conservative lung-exposure factors to convert the measured concentration to dose, the effective dose for a concentration of $0.57 \mathrm{pCi} / \mathrm{L}$ is $171 \mathrm{mrem}$. The effective dose for a net radon concentration (the total concentration minus background) of 0.17

$\mathrm{pCi} / \mathrm{L}$ at the nearest residence to the

\section{Percent Eouilubium}

This term describes the number of radon's daughter products that are available in the air compared to the amount of radon in the air. If half of the daughter products have been removed from the air, then the daughter products are said to be in $50 \%$ equilibrium with radon. Instances of $100 \%$ equilibrium are extremely rare, even under artificial laboratory conditions, It would take two times more radon at $50 \%$ equilibrium to produce the same dose as radon at $100 \%$ equilibrium. In general, air with a lower percent equilibrium is safer to breathe than air with a higher percent equilibrium. facility represents a dose of 51 mrem. ${ }^{37}$

This is conservative since it assumes that the individual spent $100 \%$ of the year outdoors.

The average site boundary total radon concentration of $0.57 \mathrm{pCi} / \mathrm{L}$ is about $29 \%$ of the average indoor radon concentration reported for homes in the Cincinnati area. In that study, more than half of the 2,951 homes studied had radon concentrations above $2 \mathrm{pCi} / \mathrm{L} .{ }^{38}$ 
Figure 50: Radon Monitoring Locations Near the Silos

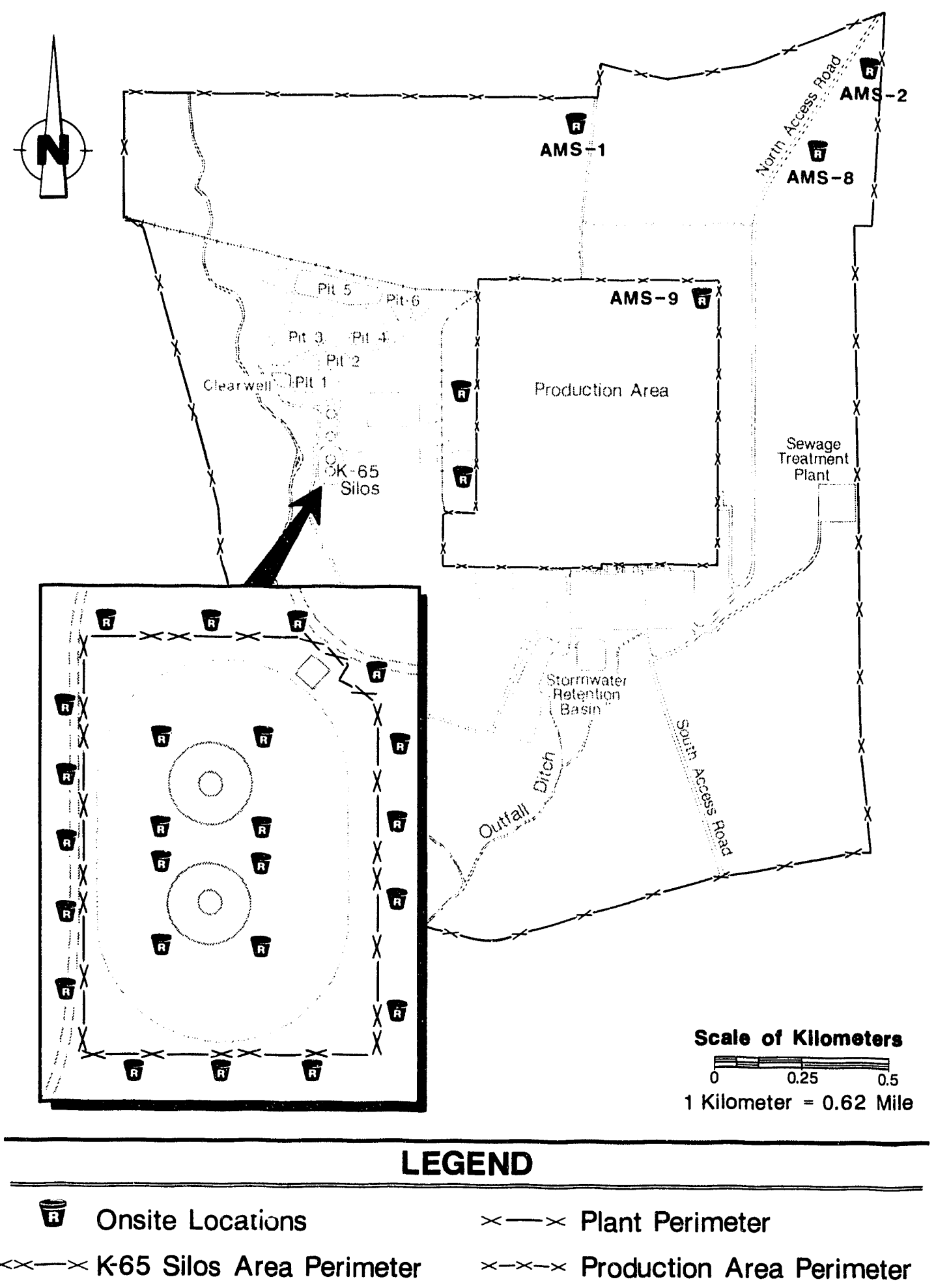




\section{Control of Radon at the Fernald Site}

As previously mentioned, steps have been taken at the site to control radon emissions. In November 1991, a bentonite (clay) sealant layer was placed over the residues contained in the $\mathrm{K}-65$ silos to reduce the amount of radon emitted into the headspace and, consequently, the atmosphere. This removal action was performed with the approval of USEPA. The clay layer essentially acts as a filter. Radon passing through the layer is retarded and decays while still in the bentonite. As a result, lower concentrations of radon are observed in the silo headspace. Additional headspace data measurements have been conducted since the bentonite addition and were continued through 1992. The data is being analyzed and reported to USEPA to assess the effectiveness of the bentonite sealant layer. Radon concentrations in the silo headspaces have been reduced substantially. No values greater than the DOE limit of $100 \mathrm{pCi} / \mathrm{L}$ have been observed at environmental monitoring stations near the silos since the bentonite sealant layer application.

The next chapter discusses the procedures and practices at the Fernald site that are used to ensure that environmental monitoring data are good representations of the conditions at the site. 


\section{Quality Assurance for the Environmental Monitoring Program}

(1)

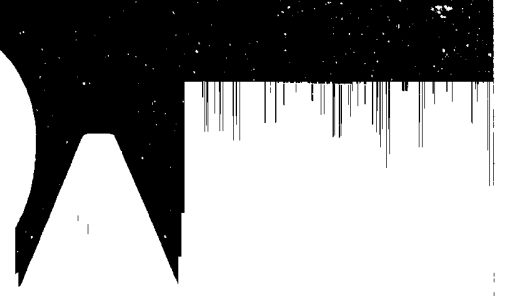




\section{Quality Assurance for the Environmental Monitoring Program}

Acquiring data of known quality is essential to environmental sampling and analysis. Because decisions are made and regulatory compliance is derived from environmental data, the Fernald site has developed comprehensive procedures that define how environmental sampling and analysis are to be conducted. These procedures generate consistency between programs and ensure that USEPA, DOE, or industry-accepted practices and standards for conducting environmental sampling and analysis are used. Quality Assurance (OA) provides the guidelines necessary to monitor the performance of these procedures in a controlled and consistent manner.

Adherence to $Q A$ requirements generates confidence that environmental data are reliable. The $Q A$ process identifies the variability in data, establishes the objectives, and defines the level of confidence needed to meet the objectives. The consistency and precision of sampling and field analysis are measured using $O A$. In the laboratory, $Q A$ measures the accuracy and precision of the analyst and analytical procedures used.

\section{Results in Brief 1992 Quality Assurance}

DOE's Environmental Measurements Laboratory (EML) Evaluation - Water. soil, and air analyses of the DOE EML samples were shown to be within accept able limits.

USEPA's Discharge Monitoring Report - All the Fernald site analyses of USEPA wastewater samples were within acceptable limits.

Proficiency Environmental Testing (PET) - Ninety-six percent of the 553 PET samples analyzed during 1992 were within acceptable limits. 


\section{Sitewide CERCLA Quality Assurance Project Plan}

The USEPA requires that environmental sampling and analysis activities mandated or supported by USEPA contain a centrally managed QA program. Since the Fernald site generates data under CERCLA, it is required to implement procedures the: ensure precision, accuracy, completeness, and representativeness of the entire program.

Collection and analysis of environmental samples are integral parts of fulfilling the site's missior and complying with environmental regulations. A single sample of a specific item from a specific location may provide information for a number of remedial investigation, restoration, waste management, and regulatory uses. Therefore, it is necessary that environmental sampling and analysis be conducted in a consistent manner that will result in usable, valid data of known quality so that use across programs is possible and the level of uncertainty associated with such data is known.

The Sitewide CERCLA Quality Assurance Project Plan (SCQ) was developed for environmental sampling and analysis activities. It established minimum standards of performance for operational and analytical activities, while ensuring that standards are followed by all programs. Implementation of the SCQ began in 1992 at the Fernald site.

\section{Data Quality Objectives}

Prior to sample collection, the Data Quality Objective (DQO) process begins. The DQO process provides a means for the decision maker and the technical team to define the level of quality needed in the data to support a decision. The regulator requirements are identified and the sampling and analysis plans are designed before the samples are generated. In designing the sampling and analysis plans, the variables established through the DQO process are used to determine the number of samples needed, including QA sample , and to ensure that the total level of uncertainty from sampling and analysis is correctly assessed. 


\section{Quality Assurance: Field Activities}

QA on field activities is an important part of the environmental monitoring process. The site's environmental monitoring procedures contain detailed QA measures for meeting the criteria established in the DQOs. Only trained personnel, who have demonstrated proficiency in making field measurements and collecting representative samples, are permitted to perform these functions. Following are examples of field activities.

\section{Field Analysis}

Field measurements offer benefits in time and cost. The measurements provide immediate results on environmental conditions, ensuring that the site maintains compliance with certain parameters. Measurements are made with instruments calibrated against known standards and according to accepted methods. QA measures for instruments include routine performance checks, maintenance, and calibration to help ensure proper operation and accurate field measurements.

\section{Field OARepresentative Sampling}

Environmental samples that field technicians collect must be representative of actual conditions in the environment. As such, the site designs sampling programs to reduce sample degradation, sampling variability, and cross-contamination.

The Fernald site takes precautions to prevent changing of sample constituents by purchasing certified clean sample containers and using sample preservatives. Such precautions are necessary to prevent changes that can occur in some samples due to biodegradation from microorganisms, the loss of volatile compounds with increasing temperature, or the loss of trace metals from solution by adsorption onto sample container walls. Refrigeration, or icing, and the addition of chemical preservatives (such as nitric or sulfuric acid) are used to decrease volatility of organic compounds, control biological and chemical changes, and maintain trace metals in solution.

The use of standardized procedures reduces sampling variability. These procedures snsure consistency from one collection to another. Sampling variability is measured iy taking multiple samples of the same type. The precision of the site's sample collection and laboratory reproducibility is demonstrated when the analysis results for the duplicate samples are within acceptable limits.

When conducting duplicate sampling, a technician collects two samples from the same location. The samples are then submitted to the same laboratory or submitted to separate laboratories as a means of assessing the precision of the analysis.

The quality of the sample collection process is also evaluated by means of field and equipment blanks. These sample blanks provide valuable data and provide a means 
of monitoring the sampling process for cross-contamination. The blanks are transported along with the sample containers being taken by the sampling team into the field. When sampling is complete, the blanks are submitted along with the field samples for laboratory analyses. A brief description of different types of blanks follows.

Trip blanks are prepared by filling sample containers with de-ionized water. Anything that will be added to the samples to preserve them after collection is also added to the blanks. The containers are then sealed with tamper-proof tape and transported to the sampling location along with the empty sample containers. The analytical results of the trip blanks detect contamination of samples from empty sample containers and preservatives. Trip blanks are also used to determine sensitivity of analytical equipment. The result from a trip blank is subtracted from the rest of the samples to obtain a result that has not been influenced by the sensitivity of the equipment used to analyze the sample.

Field blanks are prepared in the laboratory or in the field by filling sample containers with de-ionized water. The container is opened and exposed to the air while other samples are being collected. Results from the field blanks determine if airborne contamination may have entered the field samples during the collection process.

Equipment rinsate blanks consist of a composite of de-ionized water that has been used for a final rinse in cleaning sampling equipment. Results of equipment rinsate blanks are used to evaluate whether or not sampling equipment was free of contamination before being used to collect additional samples.

\section{Sample Custody}

Most environmental samples must be managed according to USEPA protocols. One such protocol is referred to as chain-of-custody. The custody procedure provides requirements for maintaining sample custody by approved personnel. A sample container and sample must be under custody at all times through final disposition. All samples are obtained and documented according to the chain-of-custody procedure. All personnel relinquishing and receiving custody of samples are required to sign, date, and note the time on a chain-of-custody record. This practice is done so that the sample integrity is maintained and all data are legally defensible.

\section{Field Documentation}

Technicians must accurately and systematically record results of field measurements and information pertinent to sample collection for subsequent evaluation and reference. Procedures direct the environmental sampling process from before collection begins to delivery to the laboratory. In field logbooks, technicians record events and observations such as weather, location, time of sampling, and any unusual events that may influence the sample. Signing and dating all documents helps ensure the traceability and accountability of results when needed in the future. 


\section{Analytical Laboratory Quality Assurance}

The Fernald site uses a variety of procedures to ensure that the laboratories analyzing its samples obtain reliable results. These procedures typically begin with the receipt of samples from the field technicians. Laboratory QA is designed to:

- Ensure use of appropriate measuring equipment,

- Ensure use of approved analytical methods,

- Evaluate analytical performance systematically and objectively,

- Detect and prevent the use of questionable data, and

- Identify appropriate corrective actions.

\section{Analytical Methods}

Many of the analytical methods used at the Fernald site are stipulated by federal laws and regulations. From time to time, modifications to these methods are needed to adjust for matrix effects or other interferences. In addition, other methods, primarily those used in radiological analysis, have not been established as standard USEPA methods. As part of QA, periodic review of the procedures verifies that the appropriate procedures are being used and modified procedures have been approved.

\section{Analytical Performance}

QA sample analyses provide a day-to-day evaluation of the performance of the site's and contract laboratories. This evaluation is conducted by laboratories analyzing National Institute of Standards and Technology reference materials, USEPA radionuclide solutions, standardized reference solutions, duplicate samples, spike samples (field samples into which known amounts of contaminants have been added), blank samples, and external proficiency samples.

In addition, the site prepares QA samples and submits them to the laboratories conducting the analyses. At least $10 \%$ of the total number of samples analyzed are QA samples that are processed along with the field samples.

The Fernald site evaluates the QA sample results and regularly submits reports to the laboratories to identify potential areas of concern. In addition to analyzing QA samples, all laboratories perform daily instrument calibrations, stability checks, and reagent checks to monitor for laboratory contamination.

Procedural performance is also monitored through sample and matrix spikes. Using these spikes, laboratories determine the percent recoveries of known amounts of analytes that were added to the samples. In addition, matrix interferences can be identified and the accuracy of the analytical procedures can be established. 


\section{Detection of Data Problems and Corrective Action}

As part of the QA program, internal and external quality groups perform surveillances on laboratory operations. Successful completion of on-the-job training and test sample performances are required to approve new analysts, and routine performance checks assess their ability to correctly perform the analytical procedures. The accuracy of the analytical method is measured by the results of QA samples. If a problem is indicated, the QA department notifies the laboratory so that corrective actions can be taken and suspect results can be evaluated and qualified. As a means of managing variations that occur in the analytical and data generation process, deviations are recorded on Corrective Action Reports. These reports are issued to the responsible manager and can be used as a means for tracking improvements in the quality system.

\section{Independent Evaluations of the Fernald Site Laboratories}

In addition to the comprehensive internal QA program, onsite laboratories regularly take part in several QA programs conducted by independent organizations. Participation in these external QA programs provides unbiased evaluations of the onsite laboratory performance and generates added confidence that results obtained for environmental samples are reliable.

External QA evaluations are conducted in the following manner. The organization conducting the evaluation prepares QA samples to which known amounts of a chemical or radioactive components are added. The samples, but not the known values of the test components, are distributed to the participating laboratories that analyze the samples and return the results. The organization administering the program then provides a performance evaluation report comparing the laboratory's results to the true values of the test components. In most cases, the report compares the results obtained by the other participating laboratories. These comparisons show whether the laboratory's analyses are within acceptable limits of accuracy or if improvements are required. The various programs are described below.

\section{DOE's Environmental Measurements Laboratory}

The Environmental Measurements Laboratory (EML) Program evaluates the performance of laboratories carrying out radionuclide analyses on environmental samples. Routinely, the Fernald site receives and analyzes water, air filters, and soil samples for uranium and submits results for comparison with other laboratories in the program. In making the comparison, DOE computes a ratio by dividing the site's result by the EML result for each analyte. The ratio equals 1.00 when the results agree exactly. 
The ratios for samples analyzed for uranium during 1992 are listed in Table 25 on page A-39. The site and EML results for uranium in the two water samples were in agreement. The ratios between the laboratories were 1.06 and 1.10 .

The results for the 1992 soil samples were in acceptable limits since the ratios of the results were 0.77 and 0.86 respectively. It is not uncommon for the results obtained by two reliable laboratories analyzing the same soil sample for parts per million of uranium to differ by as much as $25 \%$. Consequently, the difference between the values for the 1992 soil sample is not excessive, and the agreement for the samples is acceptable to both organizations.

The 1992 air filter samples ratios ranged from 1.04 to 1.44 . This difference indicates that the Fernald site laboratory may have been overestimating the amount of uranium in the environmental air samples. The Fernald site procedure for analyzing air filters is written to be conservative (in the event of an error in analysis, the tendency would be to overestimate the uranium concentration in the air filtizs) in order not to underestimate dose.

\section{USEPA's Discharge Monitoring Report}

USEPA requires all laboratories that perform NPDES permit wastewater analyses to participate in the Discharge Monitoring Report (DMR) QA program. The DMR QA evaluations of the Fernald site laboratories' performance began in 1985. This program evaluates the ability of laboratories to measure nonradioactive contaminants in wastewater. As directed by USEPA, a corresponding QA sample must be analyzed for each parameter listed in the NPDES permit. The NPDES permit parameters that are measured by the Fernald site laboratories are discussed in Chapter Five under "NPDES Summary for 1992." USEPA evaluates the results for the QA samples as acceptable or unacceptable.

Results obtained by the Fernald site laboratories for the 1992 DMR QA samples are summarized in Table 26 on page A-40. All the site results submitted during 1992 for DMR QA were determined to be acceptable by USEPA.

\section{Commercial Proficiency Environmental Testing}

The Fernald site laboratories also participate in the Proficiency Environmental Testing (PET) QA program. This is a voluntary program administered by a commercial vendor of analytical laboratory QA services. Each laboratory pays a fee to participate. Periodically, the Fernald site's Analytical Laboratory Quality Control group submits PET samples to the various onsite laboratories concurrently with field samples. Results obtained from these QA samples are compiled and submitted for evaluation by the commercial vendor. A monthly evaluation report is then provided 
by the vendor comparing the Fernald site laboratories' results to the reference values for each sample and to the results obtained by other laboratories participating in the PET program. By using this commercial service, the site has an additional resource for evaluating its laboratory performance.

A summary of the performance of the site laboratories in the PET QA program during 1992 is provided in Table 27 on page A-41. For the 27 parameters reported, $96 \%$ of the results met acceptable criteria.

The PET program does not specify criteria for overall evaluation of a laboratory; however, $96 \%$ shows a good performance, up from $92 \%$ in 1991 .

\section{Ohio Department of Health Split Samples}

Another enhancement to the Fernald site QA program is the Ohio Department of Health (ODH) Split Water and Milk Program. The site has participated in this program with the state since 1987. As the split sample program compares results of samples collected directly from the environment, the true variability in analysis between laboratories is measured.

This program is very similar to the duplicate sample program described above. Although the sampling is similar, the duplicate samples may measure a single laboratories' performance, whereas the ODH split program measures proficiency between two laboratories.

To obtain split samples, technicians alternately add a portion of the sample being collected to their individual sample containers. This collection method helps ensure that both samples are as identical as possible. Split samples are then submitted to tyo independent laboratories for analysis.

The site did not receive the 1991 ODH results for samples collected during 1991 in time to be included in the 1991 ASER, so they are presented in this report (see Table 28 on page A-43). Also, the results for the $1992 \mathrm{ODH}$ split samples were not received in time for inclusion in the 1992 report but will be presented in next year's report. 


\section{Contract Laboratory Quality Assurance}

Because of the great number of analyses required to support all its various environmental sampling and analyses, the site uses commercial laboratories to supplement its onsite analytical laboratories. Commercial laboratories must meet stringent requirements before being selected to provide environmental analytical services. Commercial laboratories, in many cases, must also be certified and have licenses from the state. To select the best qualified laboratory, experienced auditors conduct comprehensive reviews of the laboratory management, operations, and performance. These reviews are conducted before and also during the service life of the contract. Tcpics typically reviewed during the audits are:

- Analytical equipment;

- Analytical procedures;

- Personnel qualifications;

- Sample handling and preservation;

- Data evaluation and record keeping; and

- Requirements for precision, accuracy, and detection levels.

Auditors also review results obtained in independent QA programs as part of the evaluation of each candidate laboratory's analytical capabilities. Onsite audits of the laboratories' facilities and operations are then conducted by Sampling and Analysis Management, procurement, and QA personnel before final selections are made. After selecting the laboratories, QA samples are submitted regularly with field samples in order to evaluate the contract laboratories' performance on a continuing basis.

As part of the ongoing activities for evaluating the performance of contract laboratories, the site regularly submits QA samples along with field samples to the laboratory that analyzes offsite air filter samples. Twenty-nine QA air filter samples, prepared with amounts of uranium known only to the site, were submitted to the laboratory with 1992 field samples. The known amounts of uranium on the QA filters were in the range of the amounts normally present in field samples. 
Figure 51: Milk/Uranium OA Samples, 1992

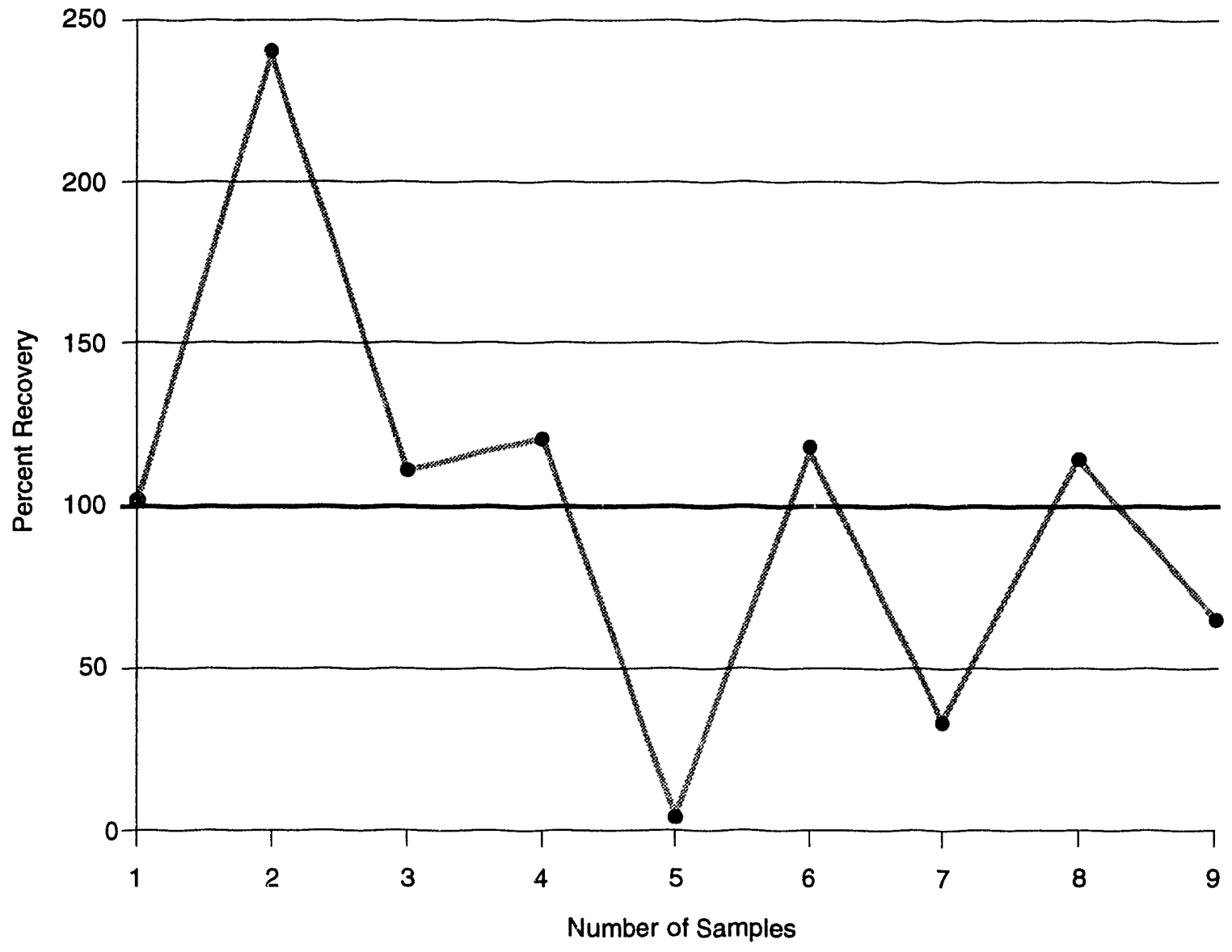

The analysis of the 1992 QA air filters was not completed in time for inclusion in the 1992 report. All results will be reported in next year's report.

The Fernald site employed the same QA measures to evaluate the contract laboratory's analysis of uranium in milk samples. Spike sample recoveries measure the accuracy of the analyses. Figure 51 shows the percent recovery for the milk QA spike samples sent to the contract laboratory used for all 1992 milk samples (data also included in table 8, page A-15). The values ranged from $1 \%$ to $233 \%$ with an average of $105 \%$. The results for the 1992 analyses were inconsistent (see Table 8 on page $\mathrm{A}-15)$.

In addition to the environmental monitoring and quality assurance activities discussed in chapters Four through Nine, the Fernald site participates in many cleanup activities. Next, Chapter Ten presents the Waste Management Activities for 1992. 


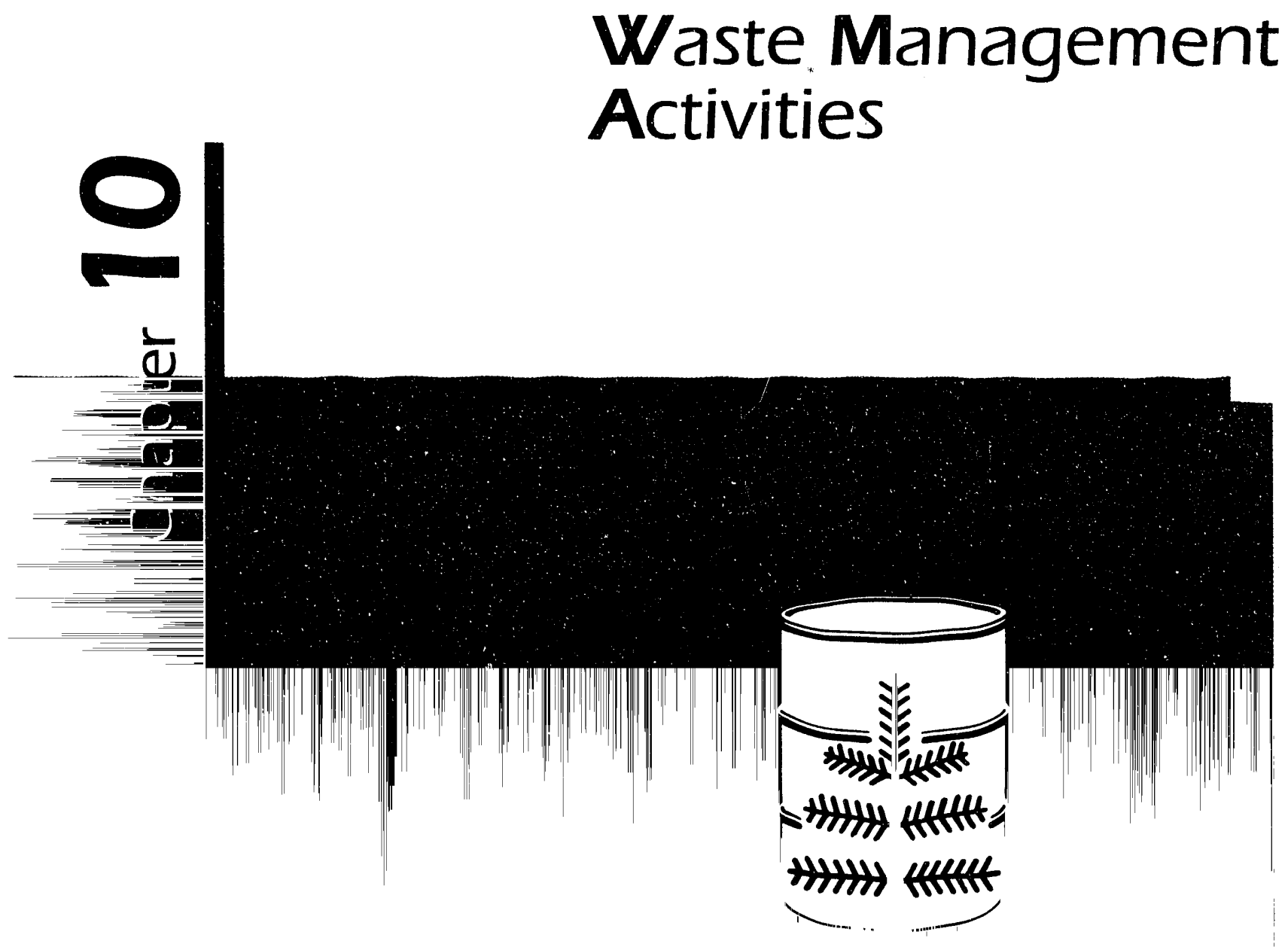




\section{Waste Management Activities}

Although production activities at the site have ended, the Fernald site's Waste Management Program continues as a key element in preventing the release of pollutants into the environment. Indeed, as remediation activities proceed, site building materials, used protective clothing, and other wastes will be generated in significant amounts.

Site personnel continue to fully integrate waste management activities with the CERCLA requirements. Much of the onsite waste is managed under removal actions within the operable units. For example, the Low Level Waste Management Removal Action, the Scrap Metal Management Removal Action, and the Soil and Debris Management Removal Action all provide comprehensive and consistent direction for safe storage and disposition of low-level waste.

Generally, the Waste Management Program seeks to characterize, store, treat (as necessary), and dispose of radioactive, hazardous, mixed, and conventional industrial waste from the site in a safe and environmentally sound manner while complying with all applicable regulations. The program also oversees waste minimization efforts throughout the facility. In 1992, there was a significant reduction of onsite waste. However, there is still an onsite backlog of

Figure 52: Drum Equivalents

In order to consistently track and report the quantities of lowlevel radioactive waste being generated and disposed, the Fernald site has adopted a uniform unit of measure - the "drum equivalent." This is defined as the number of 55 -gallon drums that it would take to contain a given volume of waste.

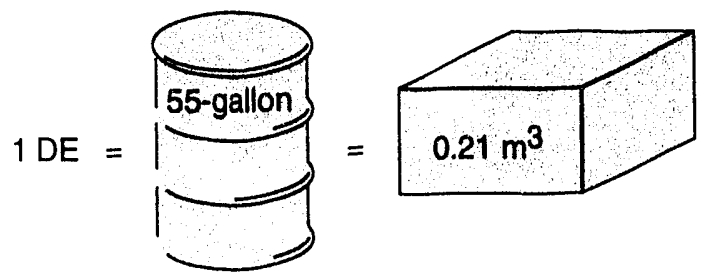

One drum equivalent (DE) is equal to the volume of a single 55-gallon drum which is $0.21 \mathrm{~m}^{3}\left(7.4 \mathrm{ft}^{3}\right)$. A unit based on drum volume was adopted since most packaged wastes at the site are stored in drums, and drums are a common unit used for shipping waste offsite for disposal. This report will use DE as a unit of measure whenever possible. approximately 141,000 drum equivalents or DEs (see Figure 52) of waste generated by the chemical and metallurgical processes during the years of production. These backlog wastes were generated after the waste pits were closed but before offsite waste disposal shipments began. The site maintains this backlog in a safe manner in proper storage containers and on concrete pads until final disposition occurs. Additionally, about 40,000 DEs of contaminated metal are stored in bulk on the Plant 1 Pad and Decontamination Pad. In addition to managing the backlog wastes, the Waste Management Program is also responsible for wastes generated by the ongoing cleanup efforts, utility, maintenance, and administrative services. 
The Fernald site manages waste safely until final disposition is implemented by ensuring that the public, site workers, and the environment are protected from the hazards associated with waste materials. Another objective is to comply with federal and state regulations, particularly RCRA, CERCLA and DOE orders. The Fernald site's strategy for meeting these objectives consists of:

- Shipping as much waste offsite as possible to permitted treatment and/ or disposal facilities;

- Maintaining and upgrading storage facilities for waste that cannot be disposed of or eliminated;

- Integrating requirements of RCRA, CERCLA, and the National Environmental Policy Act (NEPA);

- Pursuing waste minimization programs, such as the Total Quality Recycling Team and the Waste Minimization and Pollution Prevention Program; and

- Developing and implementing programs to reduce disposal costs.

This chapter highlights 1992 Fernald site activities related to management of wastes within the administration and former production areas of the site, as well as areas such as the flyash piles and the South Field. The Administrative Record and monthly progress reports are additional sources of updated information concerning onsite waste management. These documents are available at the Public Environmental Information Center. 


\section{Categories of Waste at the Fernald Site}

The wastes generated and stored onsite can be grouped into four general categories: low-level radioactive waste, hazardous waste, mixed waste, and conventional industrial waste. Examples of each of these types of waste are listed below:

\section{Low-Level Radioactive Waste}

- Process residues (slags, neutralized raffinates, sump sludges, etc.);

- Construction rubble;

- Thorium materials;

- Sediments from the Stormwater Retention Basin (SWRB) and the Biodenitrification Surge Lagoon (BSL);

- Scrap wood (pallets);

- Scrap metal (baled drums, process equipment, pipe, etc.);

- Decontamination materials; and

- Contaminated personal protective equipment (PPEs).

\section{Hazardous Waste}

- Cutting and cooling oils contaminated with solvents or lead;

- Solvent still-bottoms and sludges;

- Barium chloride salts;

- PCB-containing materials;

- Contaminated extraction solvents (tributyl phosphate/kerosene and diamylamylphosphonate);

- Spent solvents (1,1,1-trichloroethane, xylene, etc.);

- Materials used to clean spills of waste covered under RCRA; and

- Lead-containing materials (residue from paint removal, etc.).

\section{Mixed Waste}

- Any of the above-mentioned hazardous wastes combined with a radionuclide component.

\section{Conventional Industrial Waste}

- Nonprocess trash from the administration area;

- Boiler Plant flyash;

- Noncontaminated construction rubble; and

- Spent lime sludge from the water treatment plant.

The site facilities and areas within which these wastes are managed and stored are shown in Figure 53. 


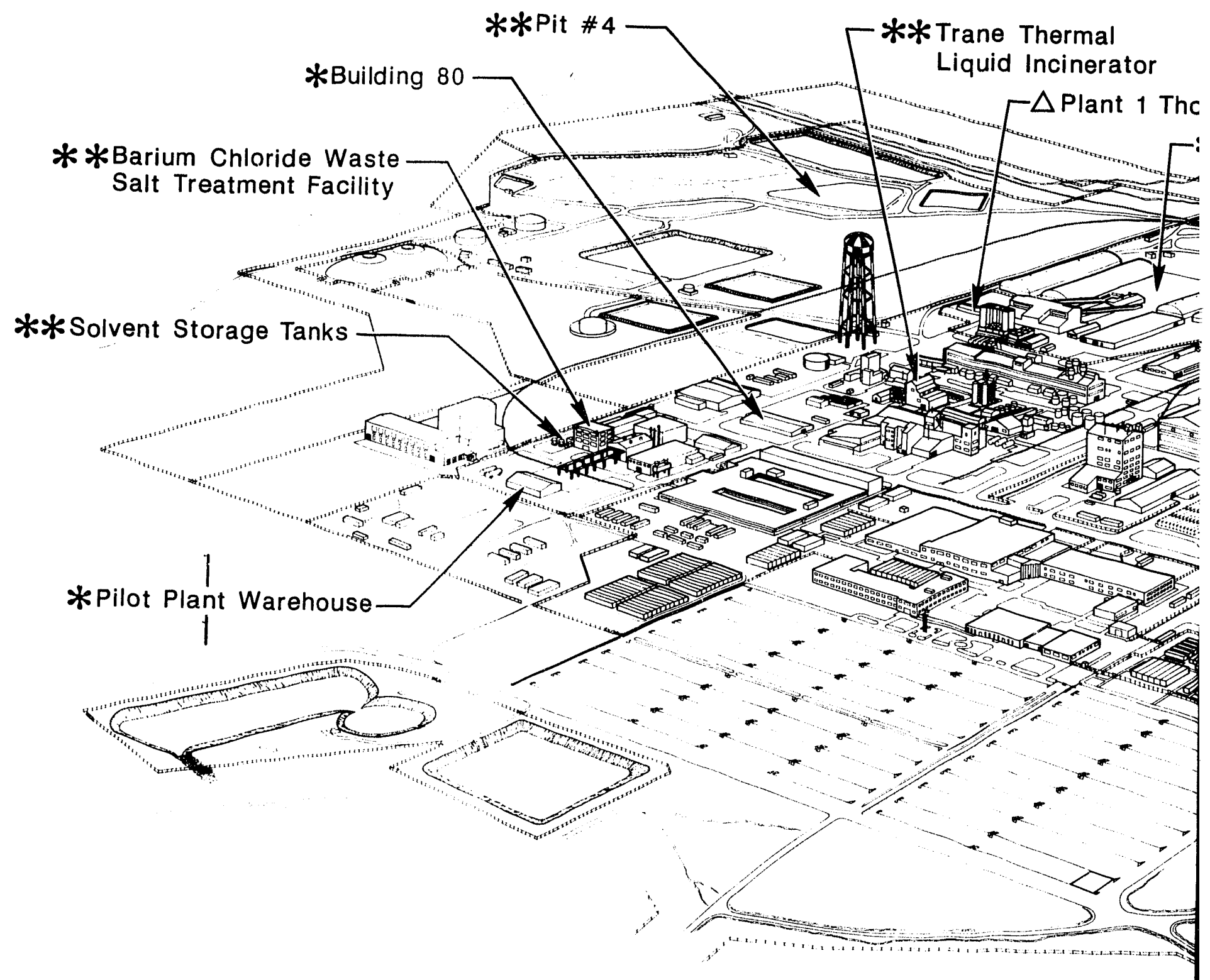

LEGEND

$\triangle$ Low Level Waste Storage *RCRA Storage Areas **RCRA Units For Closure 


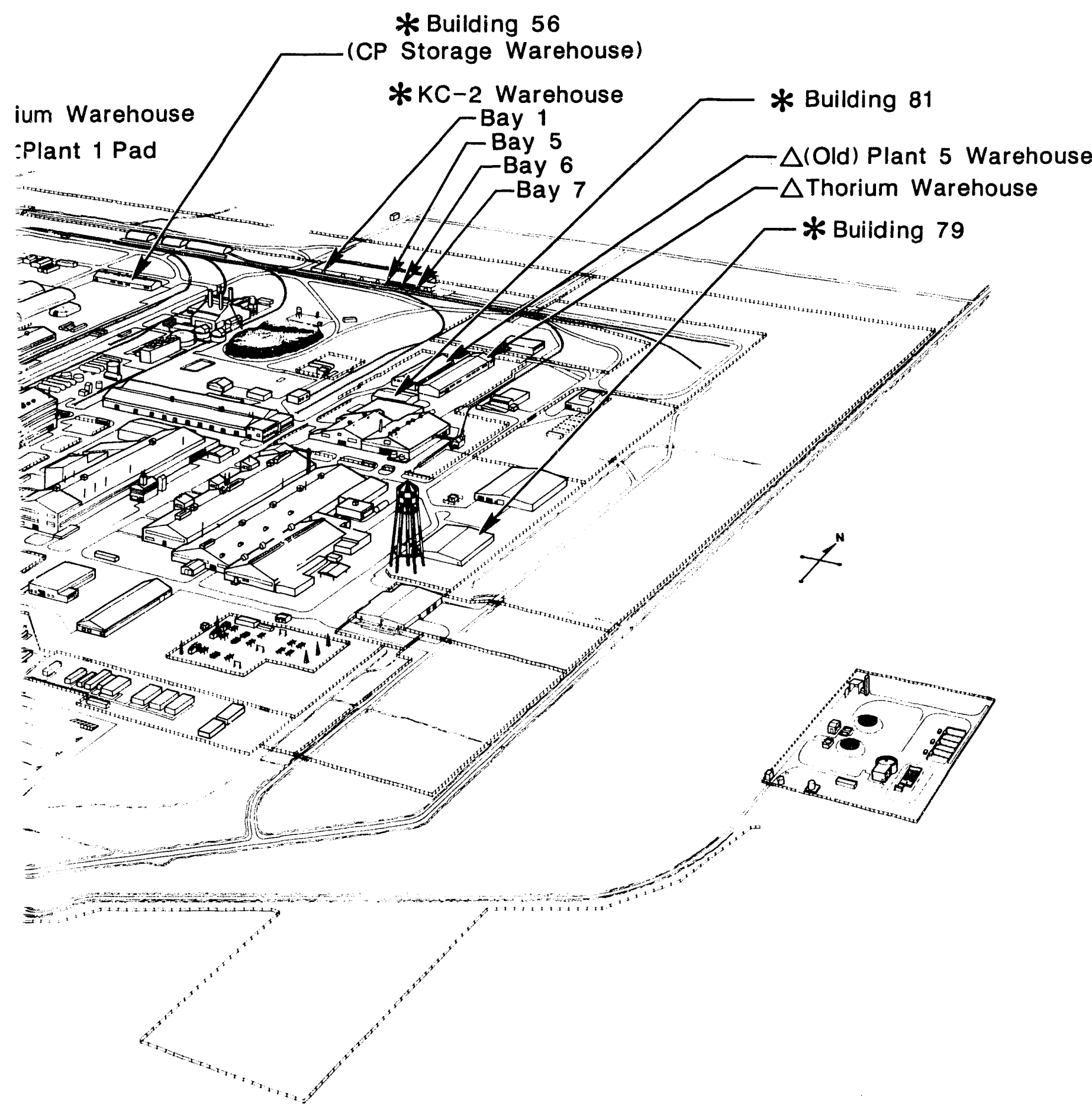




\section{Low-Level Radioactive Waste Management}

Low-level radioactive wastes (LLW) are those materials contaminated with radionuclides, such as uranium and thorium, at concentrations which are not economically viable for recovery or reuse. Some of the LLW at the site are also contaminated with hazardous constituents as defined under RCRA. Because of additional regulatory requirements, these wastes cannot be disposed or handled as LLW. These wastes are discussed in the section "Hazardous and Mixed Waste Management."

\section{Storing Low-Level Radioactive Wastes}

Because the low-level radioactive wastes and uranium residues are no longer going into onsite disposal pits or being processed to recover uranium, they are stored in drums as an interim measure until the site ships them to an approved disposal facility. Some of these drums and other containers have corroded and possibly leaked. To prevent further deterioration and potential releases of contaminants, the Fernald site began a major program to improve storage conditions in 1989 and continued it

Figure 54: Overpacking of Drums

Some of the drums stored at the Fernald site have deteriorated because of age and exposure to precipitation, sunlighi, etc. The Fernald site has overpacked many of these older drums into new containers. Overpacking means that the deteriorating drum is placed inside a new, larger drum to prevent further deterioration or the possible release of contaminants during storage

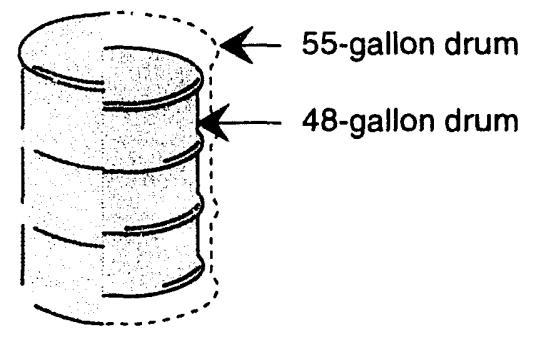
through 1992. These improvements included redrumming wastes, overpacking old drums (see Figure 54), and storing drums in the now-idle production buildings. Over 45,000 drums have been overpacked into new containers, and more than 25,000 drums have been moved from outdoor pads to covered storage areas. The site rebuilt storage pads, established minimum spacing requirements for drums, improved temporary diking, and increased inspections to detect problems as they develop. About 30,000 drums remained outdoors at the end of 1992.

In an effort to provide even better temporary storage for the backlog of low-level wastes awaiting shipment to Nevada Test Site (NTS) for disposal, two additional temporary fabric structures were erected on the Plant $1 \mathrm{Pad}$ in 1992. Each structure is larger than the three previous structures. The two new structures meet all of the requirements to store RCRA waste as well as LLW and are permitted accordingly. The total sheltered storage space on the Plant $1 \mathrm{Pad}$ is $4,300 \mathrm{~m}^{2}\left(46,000 \mathrm{ft}^{2}\right)$.

As site personnel are moving waste into the two new structures, new metal pallets are being used, and the drums are being cleaned to ensure that no loose contamination will enter the clean structures. These actions slow the transfer of waste into the buildings but will reduce long-term worker exposures and will make the eventual demolition of the structures easier and less costly. 
Figure 55: Fernald Site Backlog Waste, 1992

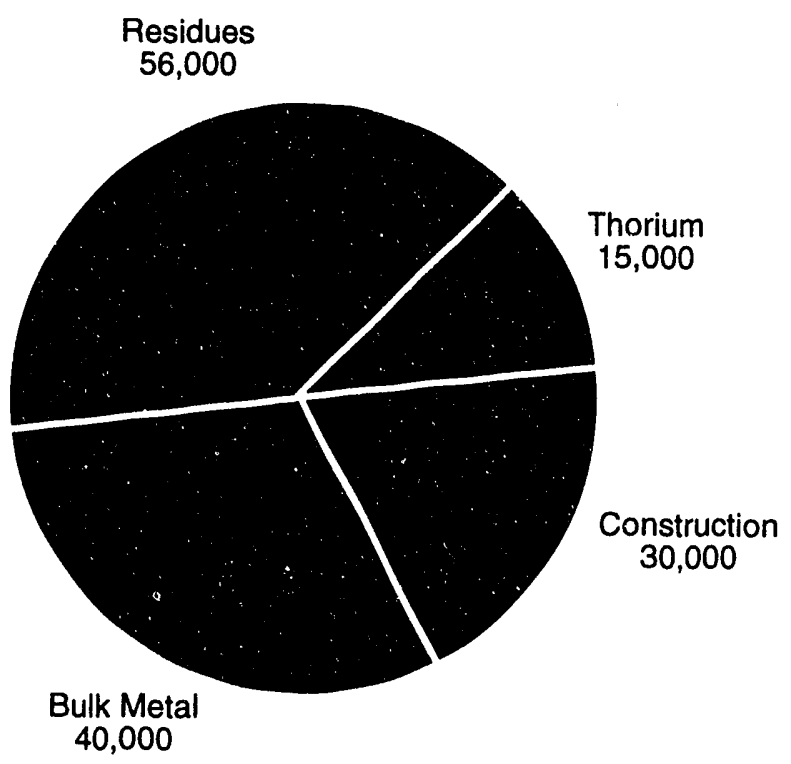

Total Backlog $\approx 141,000$ DEs
Overall, the Fernald site has improved storage conditions for and conducted rigorous inspections of more than 70,000 drums of low-level radioactive waste and residues. Backlog waste totals for 1992 are presented in Figure 55.

\section{Disposing of Low- Level Radioactive Wastes}

The low-level radioactive wastes generated onsite are regulated under the Atomic Energy Act and can be disposed of only in designated radioactive waste disposal facilities. As previously mentioned, the principal disposal site for the Fernald site's lowlevel radioactive wastes is NTS.

During 1992, the site shipped over 92,400 DEs of low-level waste to NTS. Since waste shipments began in 1985, more than 342,000 DEs have been shipped offsite. In 1992, the site began to accelerate the disposition of waste. Additional funding was provided to increase offsite shipments. The waste was primarily bulk stored waste such as scrap metal and scrap wood. As a result of the acceleration, the northeast field was completely cleared of scrap metal.

\section{Scrap Metal Activities}

Contaminated scrap metal is divided into two categories: recoverable and refuse. Nearly all of the refuse (light gauge metal) was packaged and shipped to NTS during 1992. The Fernald site awarded a subcontract to a commercial radioactive waste processing facility to recycle more than 2,000 metric tons (2,200 tons) of recoverable metal. The work is scheduled to be completed in 1993. Also, approximately 1,220 metric tons ( 1,350 tons) of contaminated copper that cannot be recovered will be packaged and shipped offsite for disposal.

Waste Management continues to aggressively pursue additional methods to provide final disposition of waste. By relying solely on NTS for burial, the Fernald site may not always be utilizing the most cost effective or responsible disposition. 


\section{Managing Thorium at the Fernald Site}

Since the early 1970 s, the Fernald site has served as the federal government's storage site for thorium, a naturally occurring radioactive element. Even before its designation as the federal repository, the Fernald site ended its thorium processing activities in 1979. There are about 1,100 metric tons (1,200 tons) of thorium stored in steel drums and other containers onsite. About two-thirds of this material was processed onsite, with the remaining portion delivered from other DOE facilities.

The site is carefully managing the thorium to reduce the potential radiation hazard to employees, local residents, and the environment to keep personal exposure As Low As Reasonably Achievable (ALARA).

Nearly all of the thorium was declared waste during 1992. In July 1992, the Fernald site initiated offsite disposal of some of the thorium waste. About 1,640 druns of thorium oxides were shipped to NTS for disposal. These shipments mark the first time that thorium from the Fernald site was disposed of as waste.

The thorium stored onsite consists of various materials, principally thorium oxides (generally a fine powder), processing residues in a variety of forms, and a small quantity of thorium metal. The majority of the remaining thorium materials, about 11,700 containers (containers vary in size from one-gallon to 55-gallon drums), is stored in the Thorium Warehouse, the (Old) Plant 5 Warehouse, and the Plant 1 Thorium Warehouse. About 9 metric tons (9.9 tons) of thorium nitrate solution are stored in Pilot Plant Tank 2.

The Fernald site is in the final stage of a comprehensive three-project plan for improving the temporary storage conditions for the thorium inventory.

The first project, completed in March 1989, addressed the bulk thorium materials in the Plant 8 silos and bins. As the bulk thorium was removed from the silos and bins, it was placed in double-containment drums called overpacks (a 48-gallon drum packaged inside a 55-gallon drum), inventoried, and monitored. The drums were then stored in an onsite warehouse located along the northern edge of the production area, away from daily plant operations. The silo and bins were decontaminated and demolished.

The second project was the overpacking of the 241 containers ( 212 of the containers were drums) stored outdoors. A remote system to handle, identify, and overpack the 241 thorium drums and containers was designed. Each container was inventoried, weighed, and overpacked, then placed in temporary storage onsite. This thorium repackaging project was completed in March 1990.

As part of the third project, overpacking in the Pilot Plant Warehouse was completed in 1992. Site personnel also conducted overpacking activities in the Plant 1 Thorium Warehouse, and these activities are expected to be completed in 1993. Overpacking 
activities are not yet complete in the (Old) Plant 5 Warehouse. Until the Fernald site can provide final disposition of the thorium waste, safe storage will be required. During 1992, some of the thorium was repackaged and transferred to the (Old) Plant $5 \mathrm{~W}$ arehouse. These movements will result in lower radiation exposures to site workers since fewer personnel enter the areas of the (Old) Plant 5 Warehouse. Plans are underway to consolidate all thorium into this warehouse pending approval for shipment to NTS.

By completing two of these projects and part of the third, site personnel have significantly reduced the potential for any accidental release of thorium through a structural failure or a deteriorating container. The new overpack containers will also protect the thorium materials from the weather and greatly reduce the possibility of any thorium being released to the environment.

\section{Hazardous and Mixed Waste Management}

Another major category of waste at the Fernald site is hazardous waste. Strictly hazardcus waste contributes very little to the total amount of waste onsite and can be disposed of readily.

Oftentimes, however, these hazardous wastes are co-contaminated with radionuclides and are, therefore, considered mixed wastes. The hazardous component of these wastes is regulated under Subtitle $\mathrm{C}$ of RCRA, while the radionuclide component of these wastes is regulated under the Atomic Energy Act, but only if it is a mixed waste. RCRA addresses a problem of enormous magnitude - how to safely dispose of the huge volumes of mixed municipal and hazardous waste generated nationwide. The goals set by RCRA are:

- To protect human health and the environment,

- To reduce waste and conserve energy and natural resources,

- To ensure proper management of hazardous waste, and

- To segregate hazardous materials from Low-Level Radioactive Waste (LLW) and conventional waste streams to minimize generation of mixed radioactive/ hazardous waste.

The Federai Facility Compliance Act (FFCAct), enacted in October 1992, allows for the storage of mixed waste at government facilities such as the Fernald site for a period of three years from the date this act went into effect. Prior to the enactment of the FFCAct, the Fernald site was in violation of the Land Disposal Restriction (LDR) Program. This program prohibited the storage of RCRA waste unless accumulation of the waste was necessary to facilitate proper recovery, treatment, or disposal options. The Fernald site was in violation of LDRs because adequate disposal facilities for mixed waste are unavailable. 


\section{Performing RCRA Closures}

When buildings, structures, and equipment subject to regulation for storage, treatment, or disposal of hazardous wastes (regulated hazardous waste management units or HWMUs) are removed from service or are to be used for other purposes, they must be cleaned and remediated to remove or control residual contamination as necessary to protect human health and the environment. The process of submitting information and data, conducting the field activities, and providing certification of the actions taken to accomplish the necessary cleaning and remediation is known as a RCRA closure.

Consistent with the December 1988 Consent Decree between DOE and the State of Ohio, RCRA Closure Plan Information and Data (CPID) are submitted discussing tasks and schedules for RCRA closure actions and related CERCLA actions that will impact RCRA Closures. CPID are prepared and submitted to ensure that closure actions are consistent with the Consent Decree between DOE and the State of Ohio, Ohio Hazardous Waste Rules, USEPA RCRA regulations, and the terms of the 1986 FFCA (as amended by the April 1990 and September 1991 Consent Agreements). The major objective in the submittal of CPID is to ensure efficient integration and coordination of RCRA closure activities with related CERCLA response actions.

In the spring of 1992, field activities based on CPID approval received in October 1991 were completed for three units: the Bulk storage Tanks T5 and T6 and the Storage Pad North of Plant 6. Certification of closure or a closure status report discussing the remaining remediation required for these three HWMUs are to be submitted to OEPA in early 1993. In addition, the Fernald site is currently awaiting OEPA comment or approval on the CPID submitted to OEPA in 1992 for the following units:

- Equipment Storage Area,

- Waste Oil Storage in the Garage,

- Drum Storage Area South of W26 (Laboratory), and

- Drummed HF Residue Northwest of Plant 4.

\section{Underground Storage Tank Investigation}

In 1992, the Fernald site underground petroleum tank closure program Operable Unit 5 (OU5) Remedial Investigation and Feasibility Study (RI/FS) Work Plan Addendum was prepared. This assessment was deemed necessary to determine the need for future characterization of underground storage tank (UST) sites where tanks had previously been removed. However, in September 1992, new regulations were issued containing cleanup standard action levels.

Comparing these new standard action levels with the Fernald site field data that were obtained during the UST removals indicated that future work would potentially not be necessary. Subsequently, the OU5 RI/FS Work Plan Addendum was delayed in 1992 pending further discussion with the fire marshal concerning these new action levels. 


\section{Conventional Industrial Waste Management}

The Fernald site also generates nonradioactive wastes, such as boiler plant waste and nonprocess trash from the administrative areas, normally associated with a large industrial facility.

During 1992, the site initiated a new program for the disposal of flyash from the Boiler Plant. Throughout the site's history, flyash was placed in above-ground piles on the site. A contract has been implemented so that the flyash waste (which is not radioactively contaminated) is buried in a local sanitary landfill. The Boiler Plant water sludges and coal pile run-off are currently drained to a retention pond, and from there the water goes to the General Sump System for treatment.

Another industrial waste is spent lime from the water processing plant. The Fernald site produces its own drinking water and process water from three onsite wells. The water treatment process includes a lime-softening step. The spent lime from this process is collected in sludge beds on the western side of the site, and these beds are nearly full. Options are being studied to address this problem.

\section{The Waste Minimization Program}

A challenge at a facility such as the Fernald site, whose mission is environmental remediation, is to include waste minimization planning and concepts in all activities and minimize any secondary wastes resulting from the remediation activities. In 1992, a step was made toward this goal by initiating waste segregation and beneficial reuse activities and promoting a conscious effort to practice waste minimization during each site activity.

Several initiatives have highlighted the Waste Minimization Program at the Fernald site. For example, approximately 510 metric tons (560 tons) of noncontaminated metal materials and 95 metric tons (105 tons) of noncontaminuted graphite materials from the safe-shutdown activities were recycled or reused.

Also in 1992, the site issued a Waste Minimization and Pollution Prevention Plan Update that sets clear, measurable waste reduction goals that were approved by staff managers and set forth as commitments to be met in 1993.

Site personnel completed a Process Waste Assessment on the contaminated, dry compactible wastestream and set a goal to reduce this wastestream by $30 \%$. The assessment led to initiating a reusable container and repackaging program at receiving and a trash segregation policy in the contaminated area. Approximately $102 \mathrm{~m}^{3}$ $\left(3,600 \mathrm{ft}^{3}\right)$ of dry compactible waste has been diverted from becoming LLW. 
A CERCLA Waste Minimization Committee was formed to perform qualitative waste assessments on current removal actions. This committee is also charged with performing quantitative assessments on all future removal and remedial actions using waste life-cycle cost analysis.

The sitewide Pollution Prevention and Waste Minimization Awareness Program developed a site-specific Pollertion Prevention and Waste Minimization video, published waste minimization articles, and sponsored "Reuse Days," Earth Week activities, employee awards, and video conference training. This program also participated in numerous community outreach programs to heighten public knowledge of waste minimization concepts.

The Waste Minimization Program had several additional accomplishments in 1992. For example, it:

- Began a program to free-release lead acid batteries generated onsite for offsite recycling, which prevents generation of a mixed waste;

- Collected approximately $2,010 \mathrm{~m}^{3}\left(71,000 \mathrm{ft}^{3}\right)$ of glass, cardboard, polystyrene, and bimetal for recycling;

- Purchased plastic reusable containers for use at receiving for repackaging incoming boxes in order to divert the cardboard and packing materials from becoming LLW;

- Recycled approximately 20 liters (5.3 gallons) of freon from mobile air conditioning units;

- Replaced selected wooden pallets in the drum storage area with metal pallets, which have five times the life expectancy and can be decontaminated;

- Segregated approximately 600 wooden pallets for reuse instead of disposing as LLW, creating a cost savings of approximately $\$ 90,000$;

- Established a procurement program to purchase recovered materials such as paner and paper products, retreaded tires, lubricating oils, concrete containing flyash, and building and insulation products; and

- Assessed the flyash and radiologically-clean asbestos material to segregate this material for disposal as sanitary waste, rather than LLW.

The next chapter, Remedial Investigation and Feasibility Study, discusses the longterm environmental investigation and the remediation activities involved in the cleanup of the Fernald site. 


\section{Remedial Investigation and Feasibility Study}

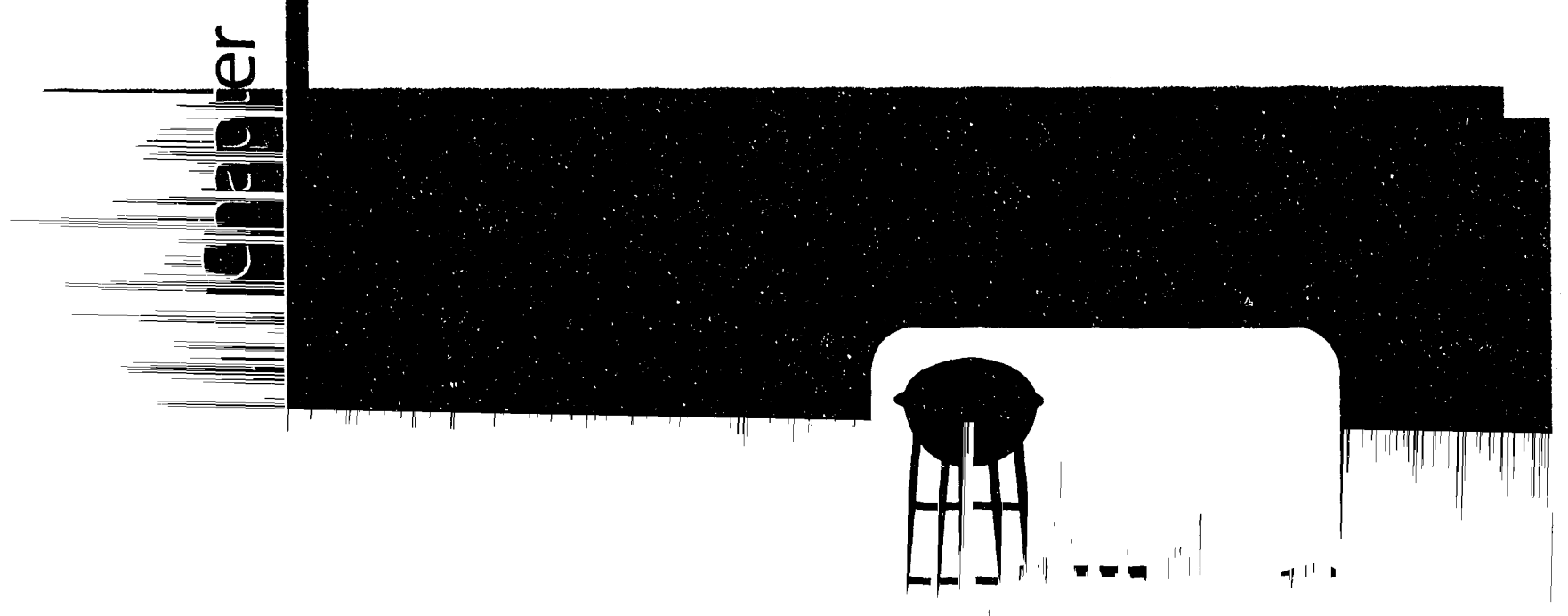




\section{Remedial Investigation and Feasibility Study}

The Remedial Investigation and Feasibility Study (RI/FS) is a comprehensive, long-term environmental investigation currently underway at the Fernald site. Its dual purposes are to identify environmental impacts associated with site operations and to develop and evaluate possible solutions. The cleanup of hazardous waste sites in the United States is driven by the Comprehensive Environmental Response, Compensation, and Liability Act of 1980 (CERCLA), as amended by the Superfund Amendments and Reauthorization Act of 1986 (SARA). At the Fernald site, the RI/FS began in 1986 and is scheduled to continue through 1998.

Those readers already familiar with the RI/FS process may wish to proceed directly to the section on Operable Unit 1 . The brief data summaries presented in this chapter cover the RI/FS activities during 1992. These summaries and proposals for the operable units are neither interpretations nor descriptions of actions taken; rather, the opera'ole unit sections that follow summarize the RI/FS program's progress. Each operable unit discussion includes the following:

- A description of each operable unit,

- The RI/FS activities that have taken place, and

- A discussion of removal action activities.

The operable unit sections in this report, hrwever, are only summaries of the RI/FS program's progress during 1992. For more current, detailed, and technical information, refer to the Administrative Record at the Public Environmental Inforn ıation Center, the repository of documentation on the RI/FS project. 


\section{The RI/FS Process}

A RI/FS process is designed to investigate the extent of site contamination, risks to human health and the environment, and best methods for cleaning up a site. The process originates when USEPA is notified of a potential problem. USEPA initiates a preliminary assessment to determine whether a response is necessary. If a response is needed, it is then decided whether immediate action is required. If immediate action is not warranted, a site investigation is conducted. With the information from the

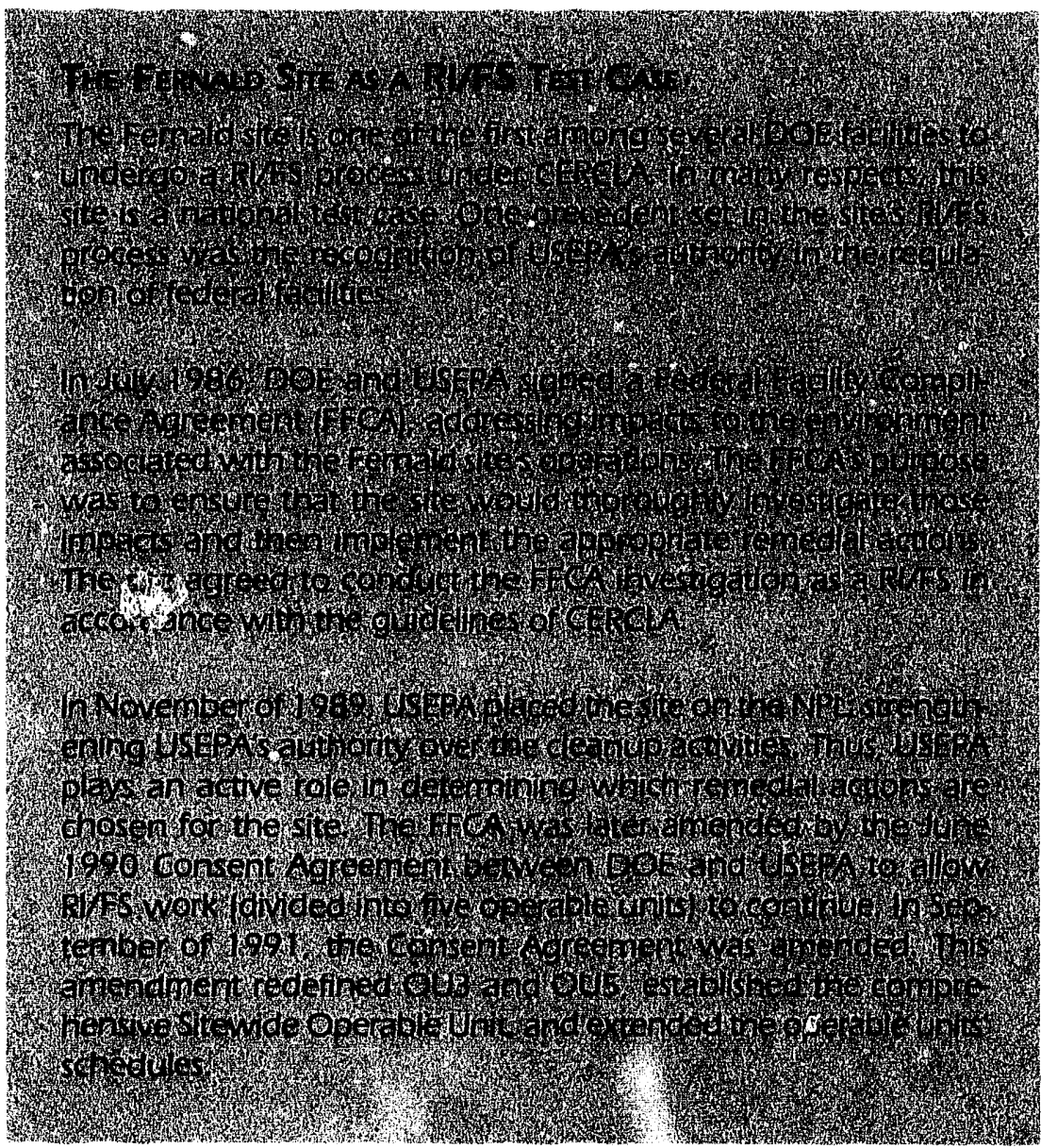
investigation, the site is ranked using a hazard ranking system. A score is allocated based on the types of hazardous materials, the potential pathways to the environment, and other similar criteria. If a score of 28.5 or over is assessed, the site is placed on the National Priority List (NPL) and must then undergo a RI/FS to determine what remedial actions will be taken.

The scope of the RI/FS does not include taking corrective actions; rather, it is an investigation process that results in a proposal for action. Based upon the results of the RI/FS, USEPA will select and the site will implement remedial actions to clean up the site. In contrast to the long-term remedial actions recommended by the RI/FS, removal actions are short-term cleanup measures designed to correct problems that are an immediate threat to human health and the environment. Removal actions often develop during the RI/FS to quickly address contamination.

The RI/FS investigation consists of three separate phases that may be simultaneously conducted. Still, no one phase is independent of the others (see Figure 56). These three phases are:

- Scoping - Development of the strategy that will be used throughout the process,

- The Remedial Investigation (RI) - Characterization of the nature ar if extent of contamination and of the risks posed to people and the environment, and

- The Feasibility Study (FS) - Evaluation of the potential remedial options. 
Figure 56: The RI/FS Process

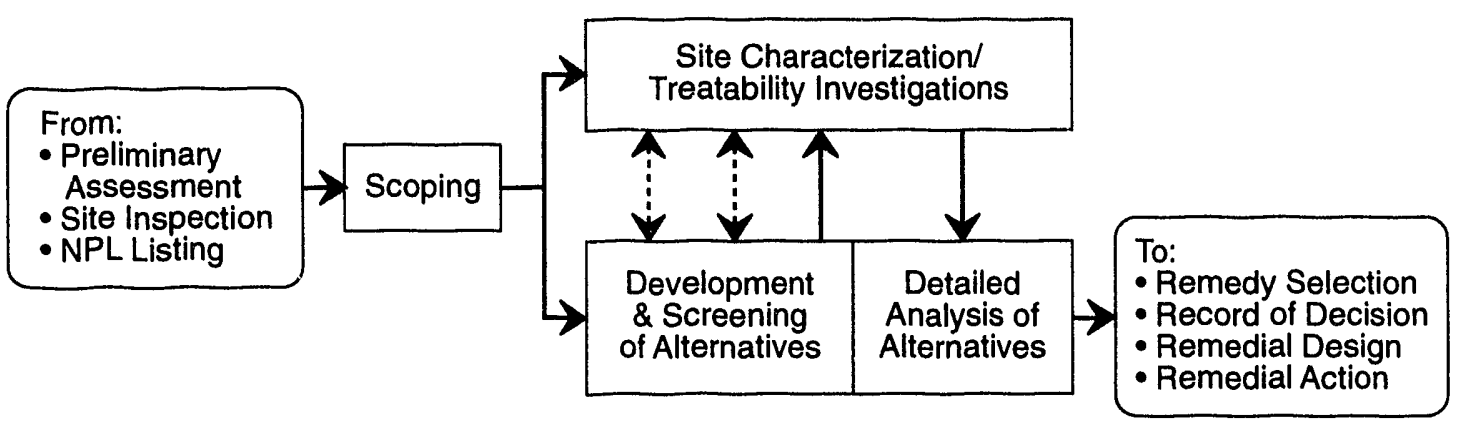

Completion of the RI/FS leads to the chain of events that is essential to final site cleanup. These final steps are:

- Remedy selection,

- Record of decision (ROD),

- Remedial design, and

- Remedial action.

\section{Scoping}

The scoping phase begins with a site visit by USEPA. All existing data are evaluated, and a conceptual model of the site is developed. To expedite the completion of total

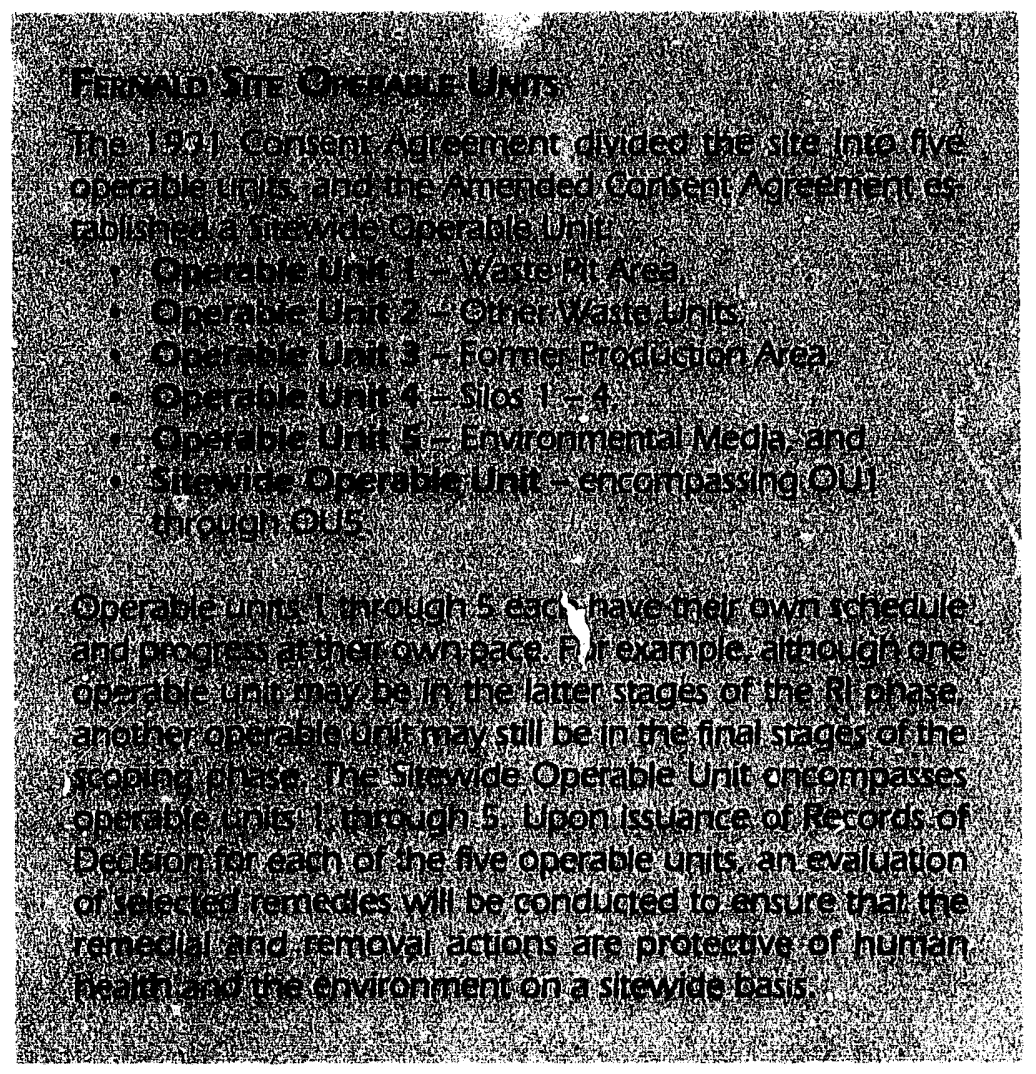
site cleanup, sites are often divided into sections called operable units (OUs). The OUs are typically defined such that similar physical properties and geographic orientation can be used to more efficiently manage the RI/FS process. (See Figure 57 for operable units.) Early in this process, all other Applicable or Relevant and Appropriate Requirements (ARARs) are identified to define cleanup levels and establish criteria on a site-specific basis. Examples of ARARs include the Resource Conservation and Recovery Act (RCRA), the Clean Water Act, the Clean Air Act, and State legislation. These ARARs are used to help determine the level of cleanup that must be achieved at a site. With this information, a work plan is prepared. 


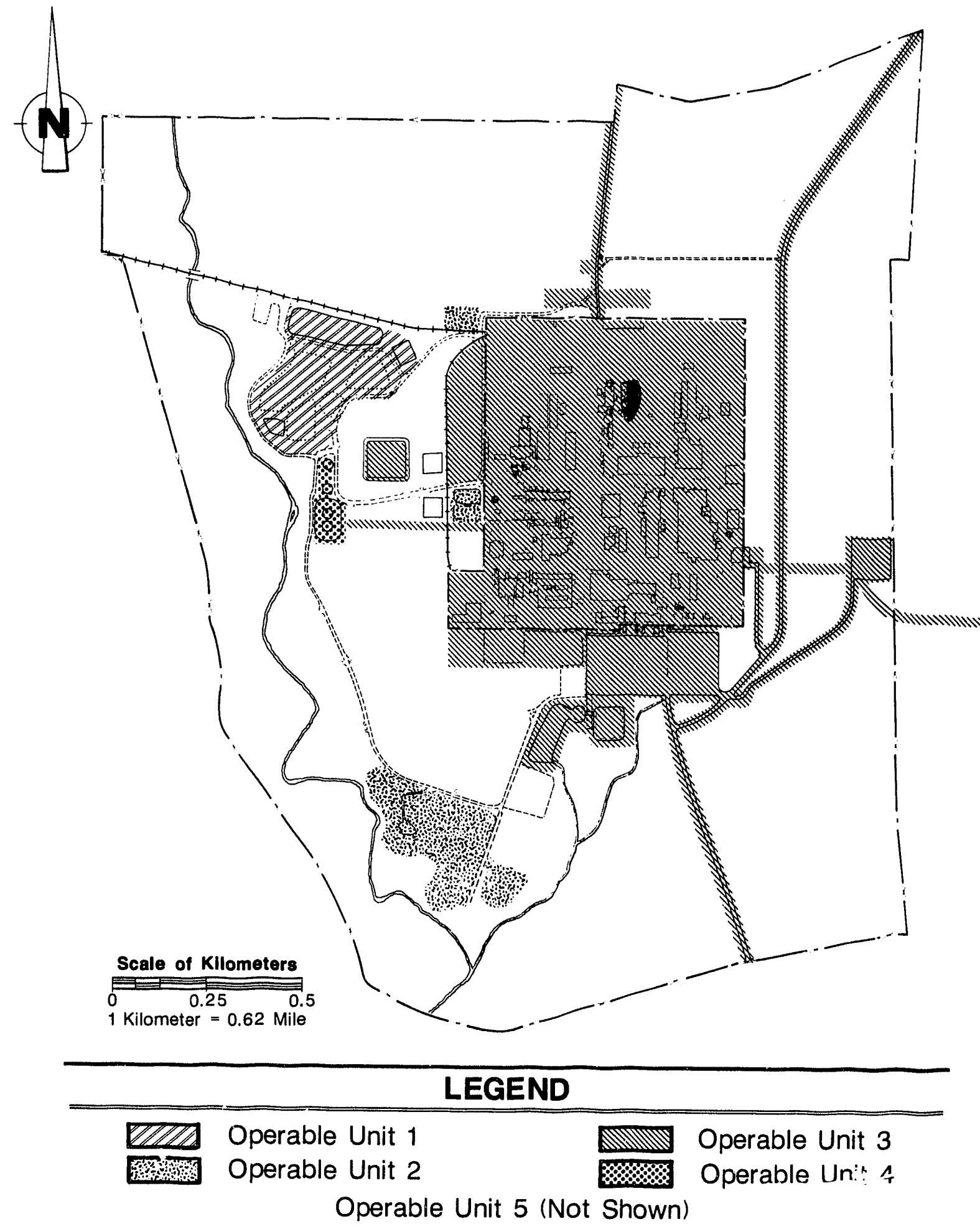




\section{Remedial Investigation}

The Remedial Investigation (RI) uses the project plan to conduct extensive field investigations. These investigations define the nature and extent of the contamination

\section{RISK ASSESSMENT}

Risk assessment is a part of each OU's RI report. The scope is to:

Identify and assess the toxicity of all radionuclides and chemicals of concern within the OU;

- Estimate risks to human health the environment, and ecological receptors; and

- Support the development of preliminary and final remediation goals. onsite. Each OU also performs a Baseline Risk Assessment. Based upon this information, each OU generates an RI report that supports the FS.

\section{Feasibility Study}

The Feasibility Study (FS) for each OU describes and compares alternatives for remediation. These alternatives are developed to meet Remedial Action

Objectives (RAOs), the cleanup goals set to protect human health and the environment.

During the FS, alternatives for long-term remedial action are screened and evaluated based on the following criteria:

- Overall protection of human health and the environment;

- Compliance with ARARs;

- Long-term effectiveness and permanence;

- Reduction of toxicity, mobility, and volume through treatment;

- Short-term effectiveness;

- Implementability;

- Cost;

- State EPA acceptance; and

- Community acceptance.

Working with USEPA, DOE recommends remedial action alternatives for each operable unit. Following the release of the FS reports, State and community acceptance of the recommended alternatives are evaluated. As more data are collected in the RIs, both the remedial goals and the selected alternatives may change. Thus, the $\mathrm{RI} / \mathrm{FS}$ is an ongoing and complex process. 


\section{Operable Unit 1 - Waste Pit Area}

Operable Unit 1 (OU1) covers approximately 15 hectares ( 37 acres) and consists of onsite facilities that were used during uranium production for storage of low-level radioactive waste, such as waste pits 1 through 6 and the Clearwell.

The immediate surrounding areas affected by these storage facilities are also studied as part of OU1 (see Figure 58). Waste pits 1 through 6, located west of the former production area, contain a variety of liquid and solid wastes that were generated by the eight separate operations plants at the site. Pits 1 through 3 are covered with earth. Pit 4 is covered with earth and a hypalon layer, and pits 5 and 6 are covered with water. The Clearwell was a settling pond, and the Burn Pit contains residue from burned refuse.

\section{RUFS Activities}

In 1992, a USEPA-approved laboratory completed the analysis of materials taken from waste pits 1 through 4 and the Burn Pit to determine the concentration of

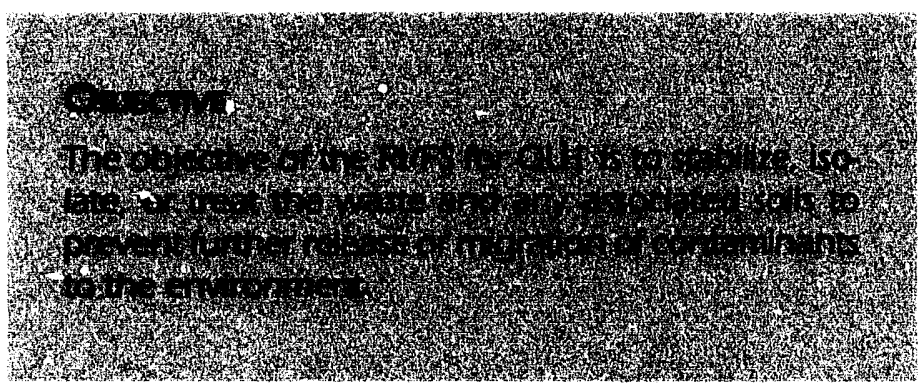
radiological and chemical constituents in OU1. Personnel reviewed all aspects of the data collection and laboratory analyses against an established set of criteria to ensure validation of this data. The data collected prior to the beginning of the study are undergoing validation. Materials from the pits are being tested for treatment technologies such as solidification and vitrification.

\section{OU1 Removal Actions}

In July 1992, the Waste Pit Area Runoff Control Removal Action was completed. This removal action provides a system for collecting and treating of potentially contaminated stormwater runoff from the waste pit perimeter areas and around the silos to prevent it from reaching Paddys Run.

The Pit 5 Experimental Treatment Facility Removal Action was completed ahead of schedule in March 1992. This facility was dismantled, and the building materials and sludge were packaged for safe storage pending final disposition.

The removal action to Control Exposed Material in Pit 5 was nearly completed by the end of 1992. Scheduled for completion in early 1993, this removal action is designed to eliminate the possibility of airborne contamination resulting from exposed materials in the pit.

The work plan for the Waste Pit Containment Improvement Removal Action was approved by Ohio and USEPA in December 1992. This removal action is scheduled 


\section{Remedial Investigation}

The Remedial Investigation (RI) uses the project plan to conduct extensive field investigations. These investigations define the nature and extent of the contamination onsite. Each OU also performs a Baseline

\section{RISK Assessment}

Risk assessment is a part of each OU's RI report. The scope is to:

- Identify and assess the toxicity of all radionuclides and chemicals of concern within the OU;

- Estimate risks to human health, the environment, and ecological receptors; and

- Support the development of preliminary and final remediation goals.
Risk Assessment. Based upon this information, each OU generates an RI report that supports the FS.

\section{Feasibility Study}

The Feasibility Study (FS) for each OU describes and compares alternatives for remediation. These alternatives are developed to meet Remedial Action

Objectives (RAOs), the cleanup goals set to protect human health and the environment.

During the FS, alternatives for long-term remedial action are screened and evaluated based on the following criteria:

- Overall protection of human health and the environment;

- Compliance with ARARs;

- Long-term effectiveness and permanence;

- Reduction of toxicity, mobility, and volume through treatment;

- Short-term effectiveness;

- Implementability;

- Cost;

- State EPA acceptance; and

- Community acceptance.

Working with USEPA, DOE recommends remedial action alternatives for each operable unit. Following the release of the FS reports, State and community acceptance of the recommended aiternatives are evaluated. As more data are collected in the RIs, both the remedial goals and the selected alternatives may change. Thus, the $\mathrm{RI} / \mathrm{FS}$ is an ongoing and complex process. 
Figure 58: Operable Unit 1 (OU1)

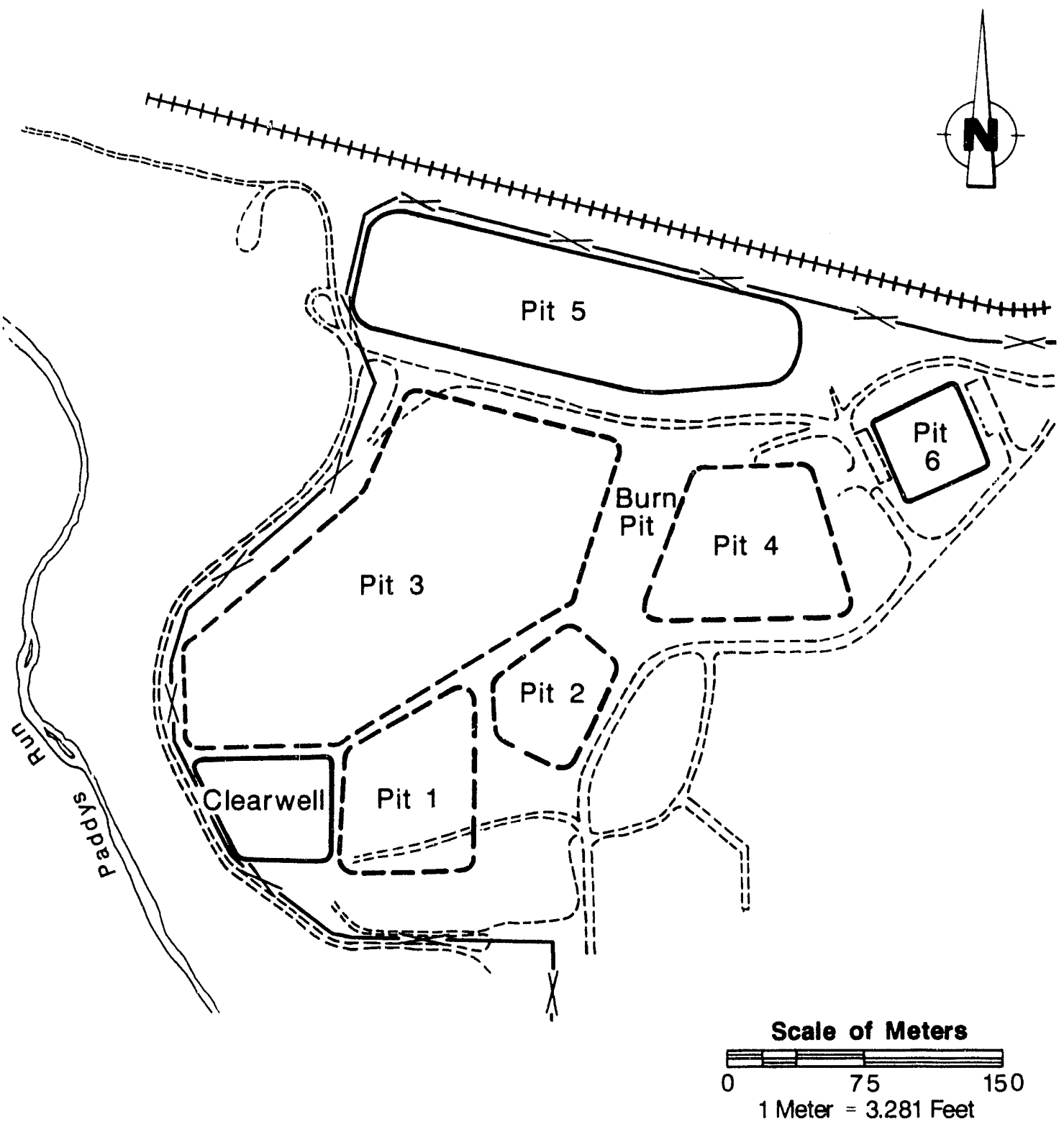

\section{LEGEND}

Operable Unit 1 consists of the six Waste Storage Pits, the Clearwell and the Burn Pit.

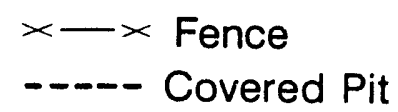

ニニニニ: Roadway

H+H+1+H Railroad Spur 
to be completed in August 1993, and it will minimize the potential for wind or water erosion of contaminated materials from access roads and exposed surfaces within the OUl area.

\section{Operable Unit 2 - Other Waste Units}

Operable Unit 2 (OU2) consists of those facilities used for the storage or disposal of solid wastes from the site operations (see Figure 59). These areas are the:

- Inactive Flyash Pile,

- Active Flyash Pile,

- South Field Disposal Area,

- North and South Lime Sludge Ponds, and

- Solid Waste Landfill.

The waste units in OU2 primarily consist of relatively large volumes of waste with small amounts of hazardous chemicals or radionuclides. The Solid Waste Landfill operated until 1986 and received about $15,000 \mathrm{~m}^{3}$ (19,600 cubic yards) of cafeteria wastes, rubbish, and other wastes from nonprocess areas. Asbestos- and

radionuclide-contaminated construction rubble

\section{Obuective}

The objective of the RI/FS for OU2 is to mitigate a potential source of contamination resulting from large volumes of waste material that may have been contaminated with small amounts of hazardous chemicals and radioactive materials during site operations. and other material have also been disposed of in the landfill.

The Lime Sludge Ponds received spent lime sludge from water treatment plant operations and neutralization of boiler plant blowdow' $n$. The North Lime Sludge Pond is partially covered with water and contains approximately $4,200 \mathrm{~m}^{3}(5,500$ cubic yards) of sludge. The South Pond is dry and contains approximately $8,950 \mathrm{~m}^{3}$ (11,500 cubic yards) of sludge. This pond has been overgrown with grass and shrubs in some locations.

The Active Flyash Pile disposal area has an estimated volume of $45,000 \mathrm{~m}^{3}(59,000$ cubic yards). Since the mid-1960s, the pile has received ash waste composed primarily of bottom ash (70\%) collected below the site's coal fired boilers. Precipitator ash collected from pollution control devices and flyash removed from the middle levels of the boiler comprise the remaining $30 \%$ of the ash waste.

The Inactive Flyash Pile received ash from 1952 to the mid-1960s. Ash volume in this area has been estimated at $60,000 \mathrm{~m}^{3}$ (78,500 cubic yards). Radionuclidecontaminated soils, concrete, gravel, and asphalt were also disposed of in this area. 
Figure 59: Operable Unit 2 (OU2)
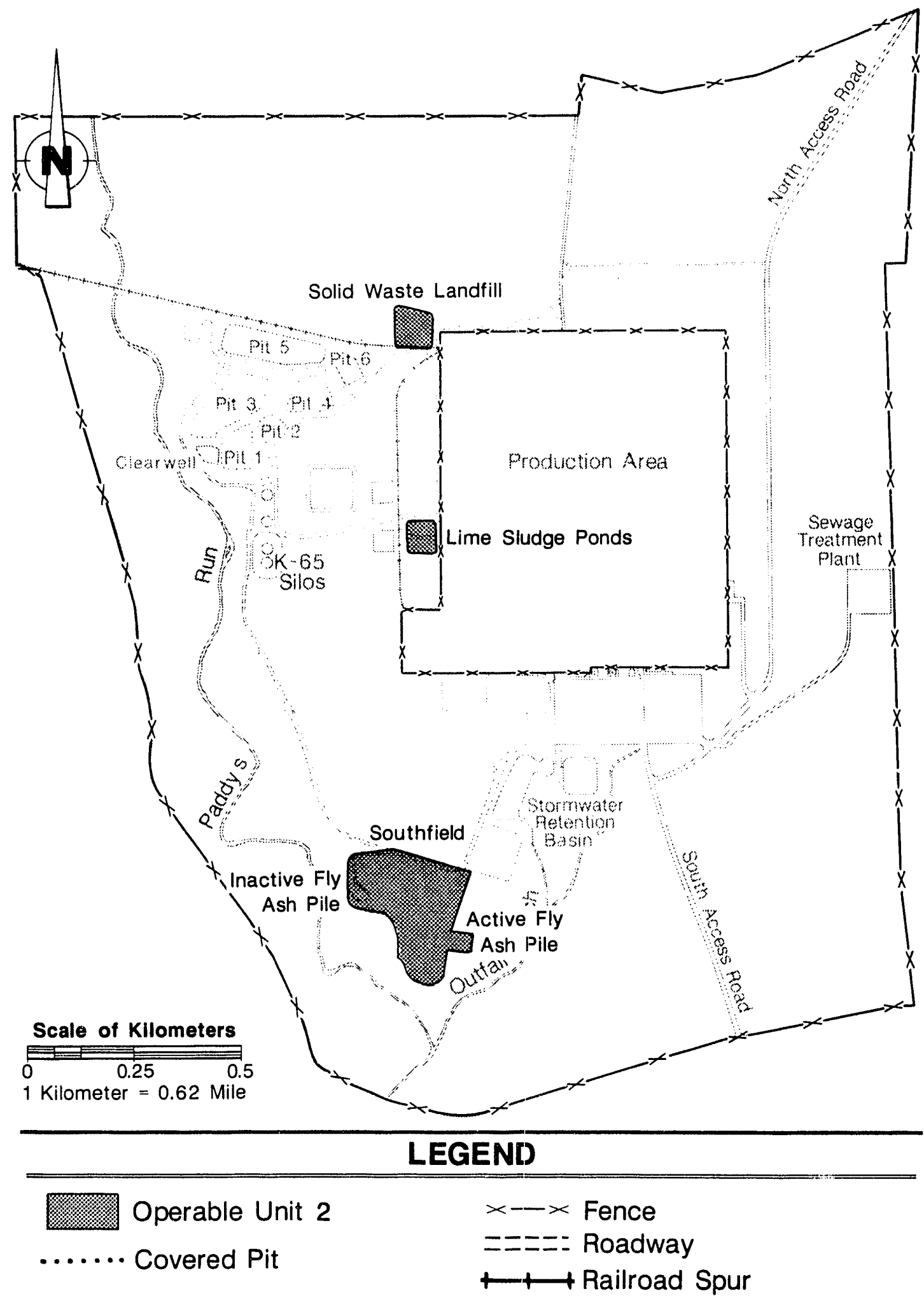
The South Field Disposal Area is reported to have been used as a disposal site for construction rubble that may have contained low levels of radioactivity. Based on a review of topographic maps from 1951 and 1988, fill volume in this area has been estimated at $83,350 \mathrm{~m}^{3}$ (109,000 cubic yards). The site's former firing range is located near the southwest end of the South Field. A soil embankment in this area was used for over 35 years by site security personnel as a catchment area for lead ammunition discharged during weapons qualifications.

\section{RIFS Activities}

OU2 treatability investigations focused on the application of cement-based solidification to OU2 waste material. In April 1992, a three-stage treatability study was completed at the IT Environmental Technology Development Cinter. In July 1992, OU2 submitted the Treatability Study Report to USEPA for review. This report was approved in October 1992 pending incorporation of USEPA comments.

OU2 submitted the draft Remedial Investigation Report to USEPA in October 1992. This report provides a summary of available field and analytical data and completes a Baseline Risk Assessment that evaluated OU2 imposed risks on human health and the environment. In December 1992, USEPA concluded that the data contained in the report did not adequately support the risk assessment and other activities necessary for the Record of Decision. DOE has proposed that additional field sampling and analysis be performed to ensure that the available data provide a high confidence level for evaluating and recommending of remedial alternatives.

\section{OU2 Removal Actions}

In June 1992, the Active Flyash Pile Controls Removal Action was completed with the installation of a silt fence around the base of the pile to mitigate stormwater runoff and the placement of wind barriers to mitigate wind erosion. In December 1992, ash disposal at the active pile was discontinued. Newly generated ash is now disposed of offsite at a licensed commercial facility.

The Inactive Flyash Pile Removal Action was completed in the fall of 1992 when a small amount of contaminated debris was removed from the Inactive Flyash Pile and placed in appropriate containers for storage pending final disposition. This action was in addition to the Inactive Flyash Pile Controls Removal Action that was completed in December 1991. 


\section{Operable Unit 3 - Former Production Area}

The 1991 Amended Consent Agreement expanded the definition of Operable Unit 3 (OU3). All plants and facilities that were involved in producing uranium metal products and in processing thorium for other DOE programs are included in OU3 remediation (see Figure 60). The primary contaminant of concern in OU3 is uranium, although thorium and other hazardous materials were also extensively used in these process facilities. The production area and production-associated facilities and equipment (includes all above- and below-grade improvements) are the objects of OU3 cleanup. This includes, but is not limited to:

- All structures,

- Utilities,

- Tanks,

- Waste,

- K-65 transfer line,

- Fire training facilities,

- Scrap metal piles,

- Coal pile,
- Equipment,

- Drums,

- Solid waste,

- Effluent lines,

- Wastewater treatment facilities,

- Thorium,

- Feedstocks, and

- Product.

\section{RIFS Activities}

OU3 submitted its RI/FS Work Plan Addendum to Ohio and USEPAs in May 1992 for review. After incorporating USEPA comments, OU3 submitted a revised Work Plan Addendum to USEPA in December 1992. Both the RI/FS and the Work Plan for OU3 have been clarified based on USEPA comments.

\section{OU3 Removal Actions}

By 1992, the Fernald site had begun several removal actions in OU3. Those removal actions that are well underway are discussed below; a list of the others follows.

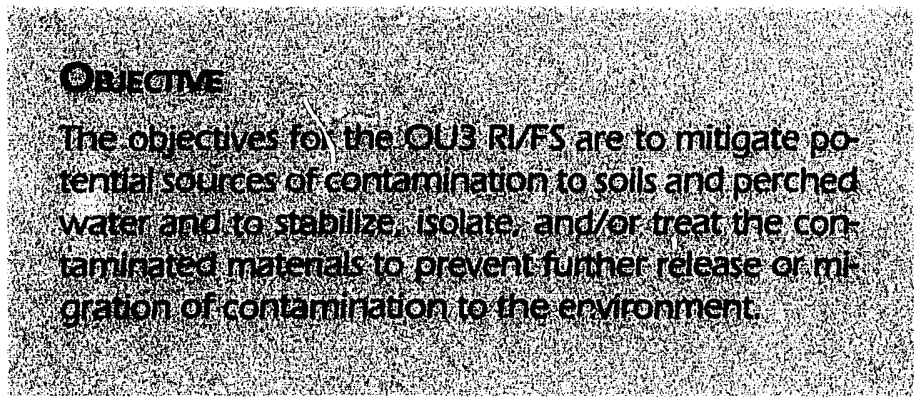

The Plant 1 Pad Continuing Release Removal Action was initiated to protect surface soils and groundwater from hazardous materials that are stored next to Plant 1. This three-part action is designed to control runoff, provide covered storage structures, and improve the surface of the existing pad surface. Phase one was completed in 1991 with interim runoff control measures. The site completed Phase two in December 1992 with the installation of a new covered concrete storage pad adjacent to the existing Plant 1 storage pad. Phase three in $y$ ! ves upgrading the existing Plant 1 pad and is scheduled for completion in 1995. 
Figure 60: Operable Unit (OU3)

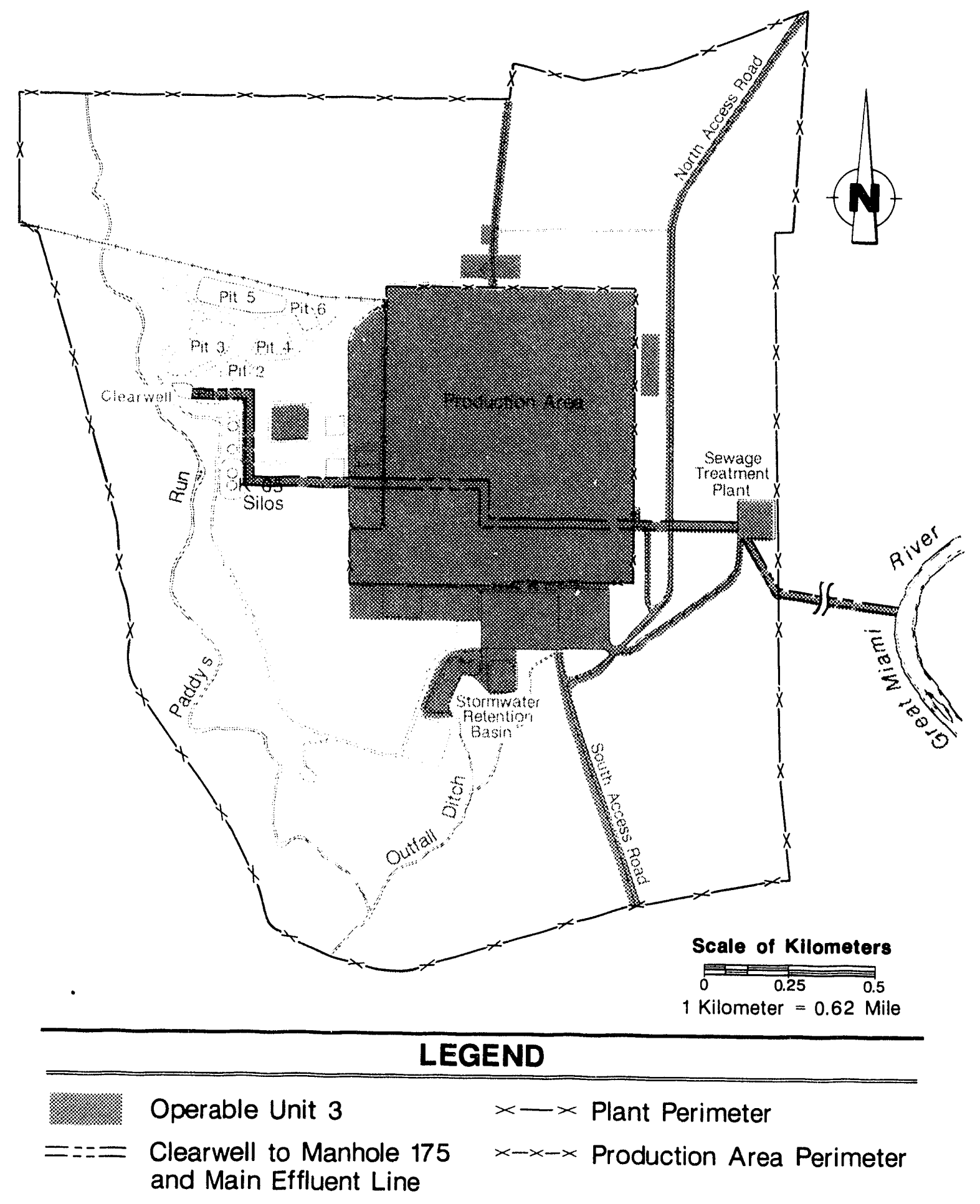


The site began processing uranyl-nitrate in September 1992 as part of the Stabilization of Uranyl Nitrate Inventories Removal Action. However, in November 1992, the site put the system on hold for evaluation. Processing is expected to resume in 1993 for completion late in the year.

Although they are underway, many of the removal actions listed below are not scheduled for completion for a few years. More current and specific information on each of the following removal actions can be found in Fernald Project Cleanup Reports available at the Public Environmental Information Center:

- Removal of Waste Inventories,

- Safe Shutdown,

- Plant 1 Ore Silos,

- Contaminated Soils Adjacent to Sewage Treatment Plant Incinerator,

- Scrap Metal Piles,

- Improved Storage of Soil and Debris,

- Plant 7 Dismantling,

- Pilot Plant Sump,

- Nitric Acid Tank Car and Area,

- Asbestos Removals, and

- Management of Contaminated Structures at the Fernald Site.

\section{Operable Unit 4 - Silos 1 - 4}

Operable Unit 4 (OU4) is defined as the geographic area (see Figure 61) that includes:

- The two K-65 silos (silos 1 and 2),

- The metal oxide silo (Silo 3),

- The empty Silo 4,

- The decant sump system,

- The buried transfer trench, and

- Soils and perched water that lie above the aquifer.

\section{Obuective}

The objective of the RI/FS for OU4 is to treat, stabilize, or isolate the silo contents, structures, and affected areas to prevent further release or migration of contaminants to the environment.
The K-65 silos are concrete storage structures that contain radium-bearing residues from past DOE operations. These two silos contain approximately 8,800 metric tons ( 9,700 tons) of residues remaining from the processing of pitchblende, a uranium-rich ore. 


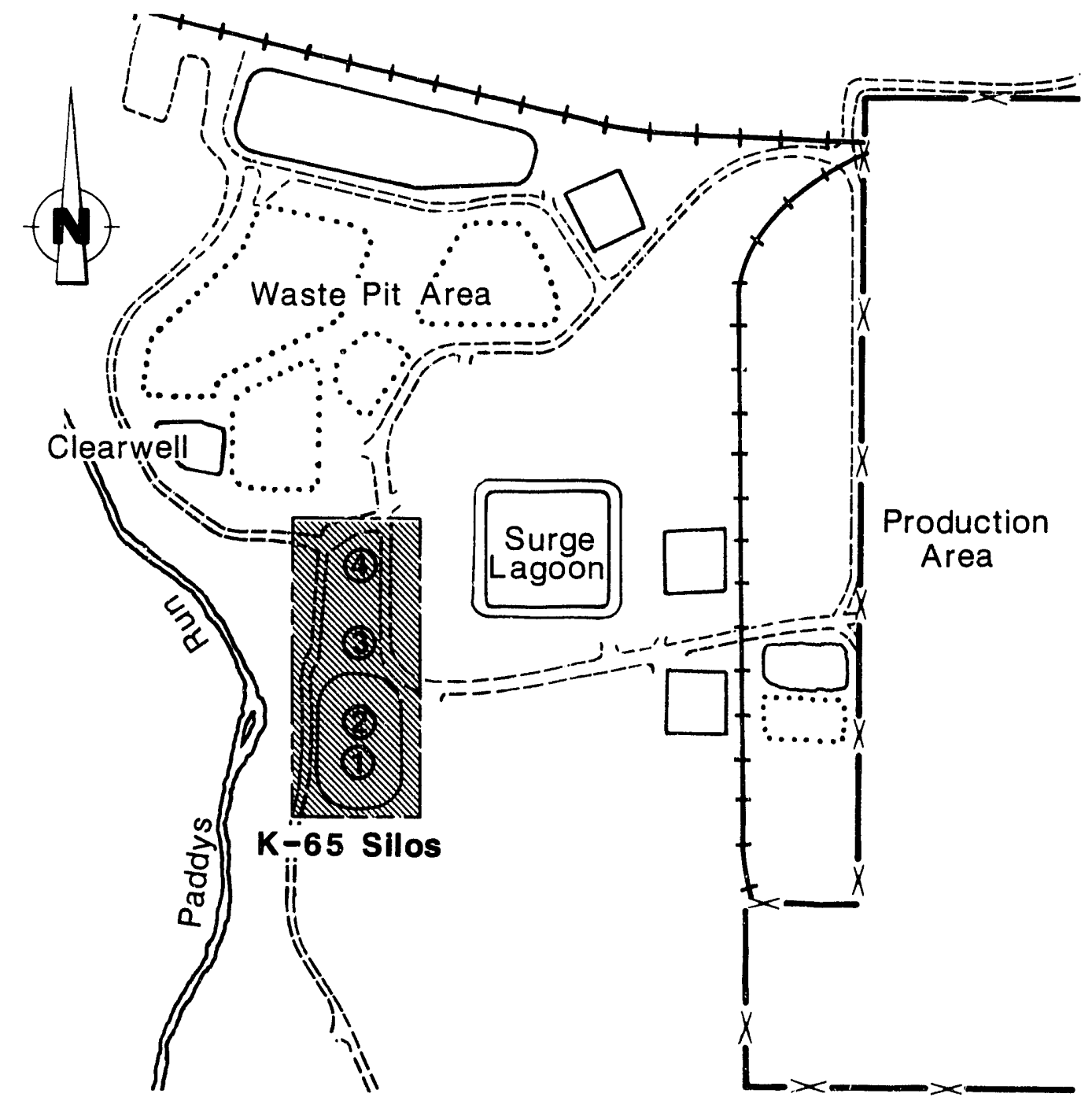

Scale of Meters

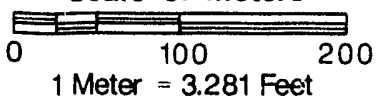

\section{LEGEND}

Operable Unit 4

$$
\begin{aligned}
& \times \longrightarrow \times \text { Fence } \\
& \text { ニニニニ: Roadivay }
\end{aligned}
$$


Silo 3 received only dry materials. Slurries from refinery operations were dried in a high-temperature evaporator and reduced to a dry waste that was blown into the silo. These wastes were primarily metal oxides. Silo 4 was never used and, therefore, is not considered to be a past, current, or future source of contaminant release to the environment.

\section{RUFS Activities}

The Fernald site has completed all characterization activities associated with the OU4 RI/FS and has received the validated data from the analyses of the collected samples. These characterization activities included the completion of borings in the berms surrounding the soils, the soils beneath the silos, and the contents of the concrete structures.

DOE and contractor personnel at the Fernald site are reviewing the RI Report for OU4. This report is scheduled for submittal to USEPA in April 1993. Compilation of the FS Report continues. In support of the FS, the site initiated studies on solidification, chemical separation, and vitrification of OU4 wastes.

\section{OU4 Removal Actions}

The Expedited Silo 3 Removal Action was completed in January 1992 when an out-of-service dust collector and hopper assembly from the dome of Silo 3 were removed. All pathways were permanently sealed to prevent the release of silo contents to the atmosphere.

\section{Operable Unit 5 - Environmental Media}

The fifth operable unit consists of environmental media that can serve as pathways for transporting contaminants. The environmental media that make up OU5 are:

- Soils,

- Flora and fauna,

- Surface water and sediments, and

- Groundwater (including perched groundwater).

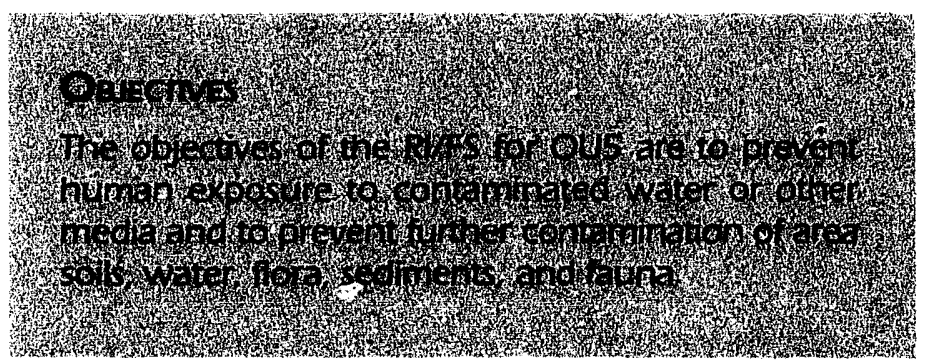

All soils not accounted for in the other operable units are investigated as part of this OU. Investigations into the flora and fauna include terrestrial vegetation and animals, aquatic communities in the Great Miami River and Paddys Run, locally grown produce and crops, and cattle grazing on potentially affected land areas. 
Surface water channels included in OU5 are the Great Miami River, Paddys Run, and the Storm Sewer Outfall Ditch. The river receives the site effluent discharge. Paddys Run receives natural surface runoff and loses flow to the aquifer through its highly permeable channel bottom. The Storm Sewer Outfall Ditch may receive excess stormwater runoff from the Stormwater Retention Basin, in addition to runoff from the eastern area of the site. As materials suspended in the water settle to the bottom of the stream or river, sediment is formed. This sediment is analyzed to determine any influence from the site.

The groundwater of the Great Miami Aquifer is carefully monitored as part of OU5 because it is a major local water source (see Chapter Six).

\section{RITS Activities}

A revised addendum to the OU5 RI/FS Work Plan was submitted to Ohio and USEPAs in October 1992 for review. These agencies conditionally approved the work plan in November 1992.

USEPA approved the OU5 Treatability Study Work Plan in September 1992. This work plan is designed to examine physical separation and chemical extraction of uranium from soils (soil washing). A pilot unit is being installed in Plant 8 to demonstrate the feasibility of soil washing as a remedial technology for cleaning the Fernald site soils.

\section{OU5 Removal Actions}

The Fernald site initiated the Contaminated Water Under Fernald Site Buildings Removal Action to minimize the potential for the contaminated water under former production buildings to work its way into the underlying aquifer. Perched water zones beneath plants $2 / 3,6,8$, and 9 are of concern, and the site began pumping operations at all locations. More than 250,000 gallons if extracted perched water were processed during 1992. A treatment system at Plant 8 uses activated carbon filters to remove volatile organic compounds (VOCs) from the extracted water. This water is then treated using the Fernald site's existing system to remove uranium before it is discharged to the Great Miami River. This VOC treatment system will continue until the Advanced Waste Water Treatment system becomes operational (planned for late 1994).

The purpose of the South Groundwater Contamination Plume Removal Action is to protect public health by limiting access to the use of uranium-contaminated groundwater in an area south of the Fernald site (see Chapter Six for further discussion about the plume). This removal action has been divided into five parts because of its magnitude. 
Part one provided an alternate water source to an industry whose well water showed concentrations of uranium greater than $20 \mathrm{pCi} / \mathrm{L}$ (the $\mathrm{DOE}$ guideline for uranium in well water) as a result of the contamination plume. The site completed Part one construction in December 1992. Another industry, which uses a minimal amount of groundwater for non-drinking purposes, will be provided with an alternate water supply via the proposed public water system.

In Part two, the site will install recovery wells in the South Plume area. Groundwater vill be pumped from these wells and piped back to the site for monitoring and discharge to the Great Miami River. Part two construction began in July 1992. The groundwater recovery well system is scheduled to be operational in August 1993.

Part three involves construction of an Interim Advanced Wastewater Treatment (IAWWT) system that removes uranium from site wastewater streams and, therefore, reduces the amount of uranium discharged to the Great Miami River. The IAWWT system consists of two separate units, the IAWWT-Stormwater Retention Basin (SWRB) and the IAWWT-Biodenitrification-Effluent Treatment System (BDNETS). The TAWWT-SWRB unit became operational in July 1992. The IAWWTBDN-ETS will be operational before the pumping of contaminated water is initiated under Part two in August 1993.

Part four includes the ongoing sampling of private wells and Fernald site RI/FS monitoring wells in the South Plume area.

Finally, Part five includes sampling of existing monitoring wells, Hydropunch ${ }^{\circledR}$ sampling, and groundwater modeling activities. The initial phase of Hydropunching is complete. Remaining portions of Part five are on hold pending property acquisition through condemnation.

The scope of the removal action to Collect Uncontrolled Production Area Runoff is to collect storn,water runoff from perimeter areas of the 136-acre former production area that is not currently draining into the SWRB but discharges into Paddys Run. The Fernald site began construction of this removal action in August 1992. It is scheduled for completion in August 1993.

\section{Sitewide Operable Unit}

The 1991 Amended Consent Agreement established a sitewide operable unit that encompasses OUs 1 through 5. After USEPA issues Records of Decision for the five OUs, they will evaluate the remedies selected for those OUs. This evaluation will help to ensure that those selected remedies are protective of human health and the environment on a sitewide basis. 


\section{Fernald Site Environmental Monitoring Data for 1992}

Numerous sampling and analysis data are required to evaluate compliance with environmental regulations and to obtain accurate indications of the Fernald site's operations during 1992. The sampling and analysis results are provided in summary tables.

Many of the numerical values listed in the following data tables are preceded by the "less than" symbol $k i$. The less than symbol is used when the concentration of a chemical species (ion, molecule, compound, or radionuclide) in an environmental media (air, water, or sediment) could not be reliably measured in the sample which was analyzed. That is, the amount of the species, if present at all in the sample, was below the minimum measurable concentration. Thus, a value of $<0.68 \mathrm{pCi} / \mathrm{L}$ listed as the concentration of uranium in milk means that the uranium concentration was less than 0.68 $\mathrm{pCi} / \mathrm{L}$ but actually could have been anywhere from 0.00 to $0.67 \mathrm{pCi} / \mathrm{L}$.

The minimum measurable concentration is not the same for all chemical species. For example, $0.25 \mathrm{pCi} / \mathrm{g}$ of radium -226 and $0.21 \mathrm{pCi} / \mathrm{g}$ of plutonium238 are the approximate minimum measurable concentrations for sediment samples. These variations exist because of differences in chemical and physical properties of species in addition to differences in the capabilities of instruments available to measure these properties.

Also, the minimum measurable concentration is not always the same for a specific species in all samples of the same environmental media. That is, the minimum measurable concentration for uranium in groundwater samples may vary for water samples from two different locations. This is so because variations in the kinds or amounts of other substances in the two samples can influence how well a substance can be measured.

In addition, the minimum measurable concentration of a species will not always be the same for identical samples from the same location which are analyzed at different times. This variance occurs because of unavoidable minor fluctuations in the performance of analytical instrumentation used to perform sample measurements.

Negative results indicate that the radionuclide activity in the sample was less than the background activity within the measurement laboratory. A negative value is obtained by subtracting the laboratory background measurement from the sample measurement. Negative results are not actual concentrations but are useful in the statistical analysis of data. 


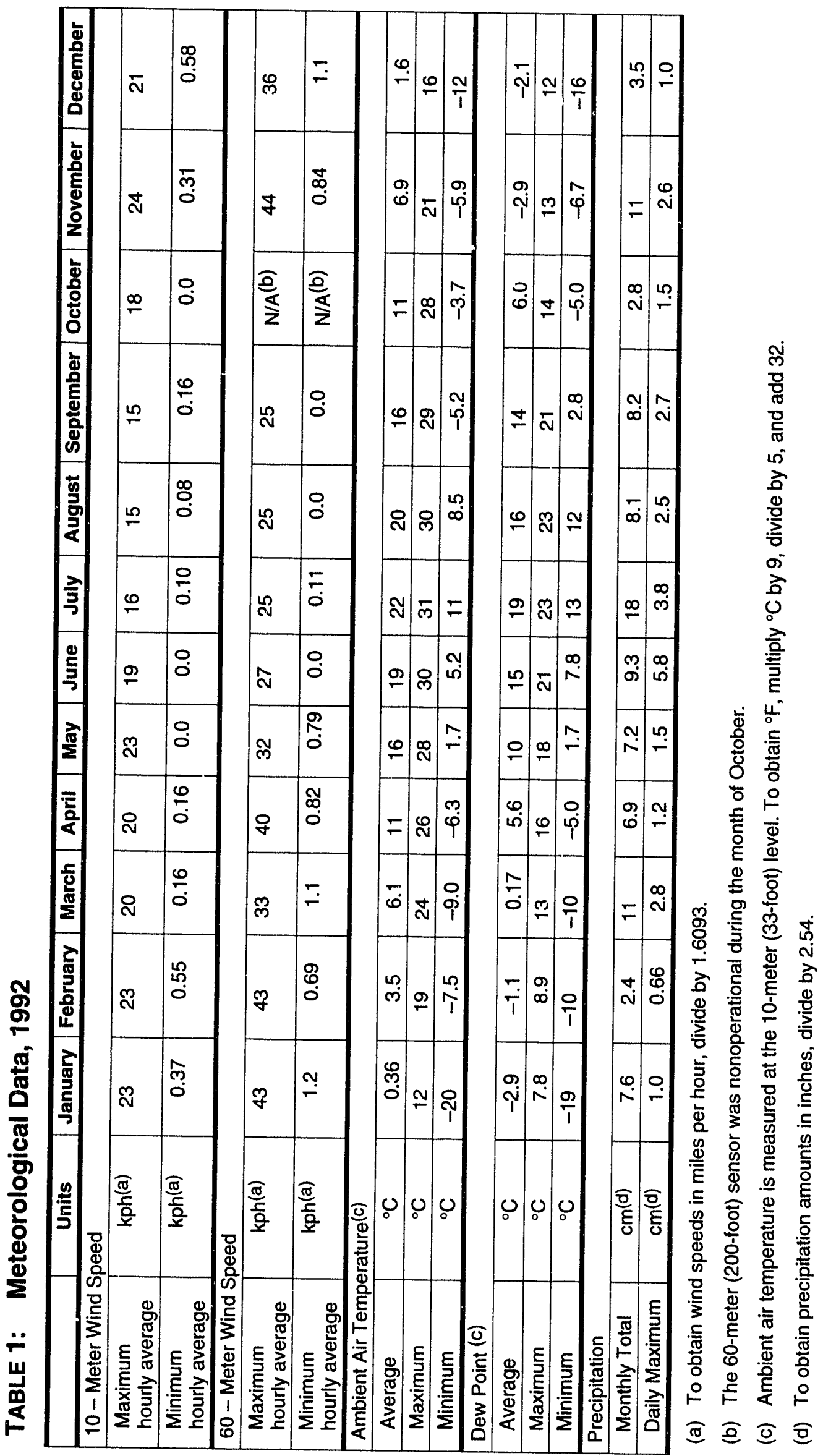




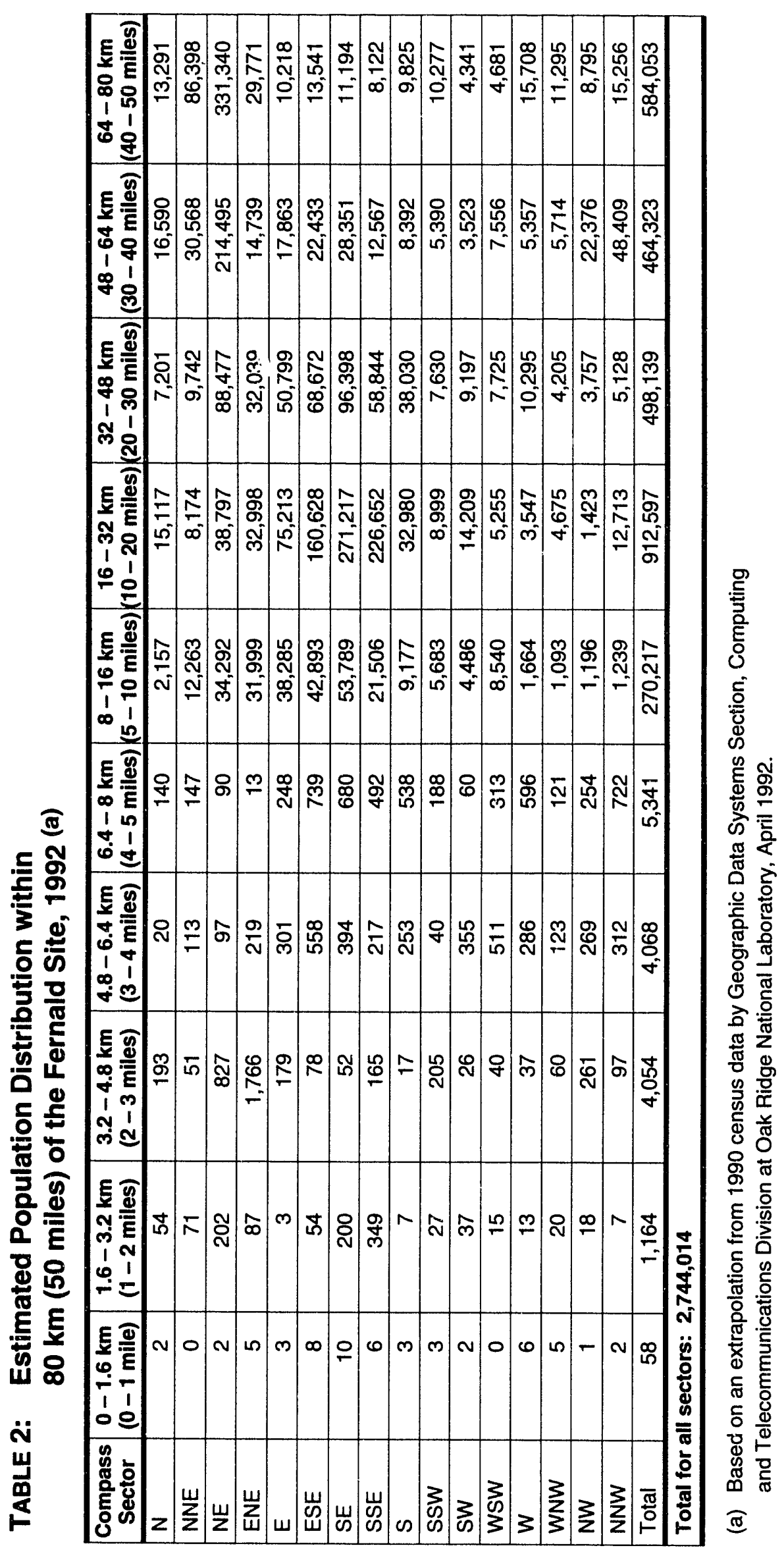




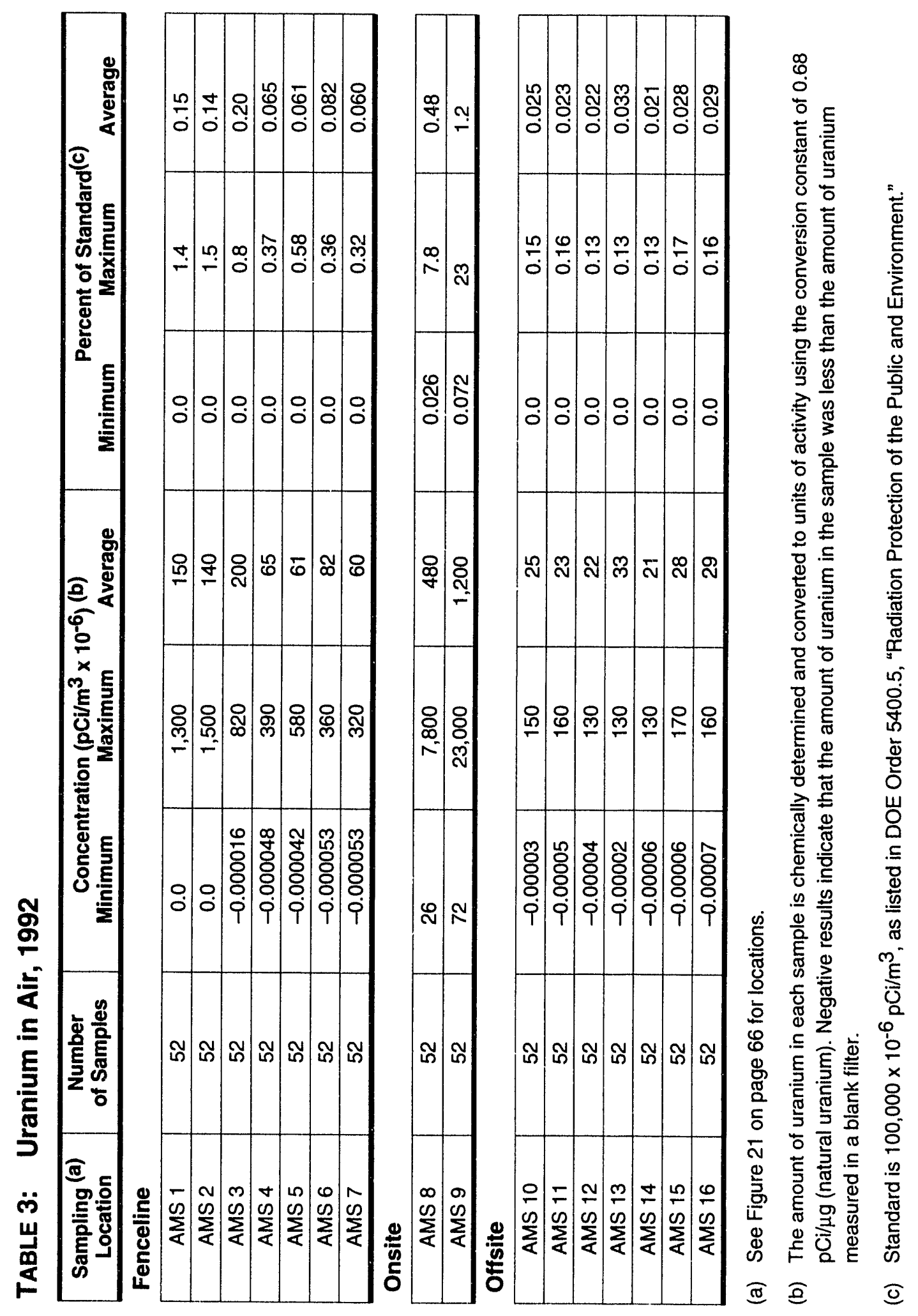


$\frac{0}{0}$

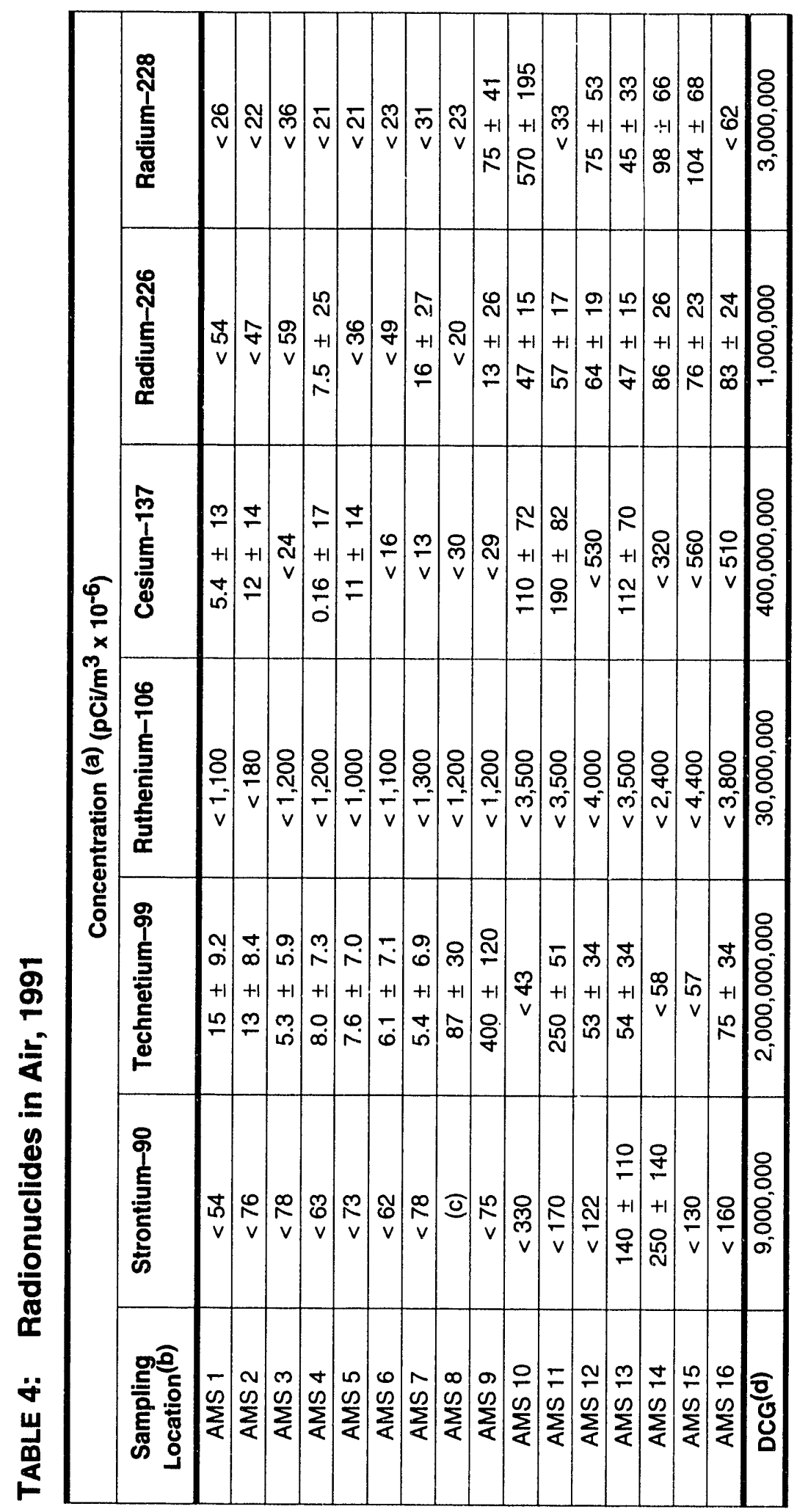




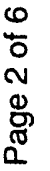

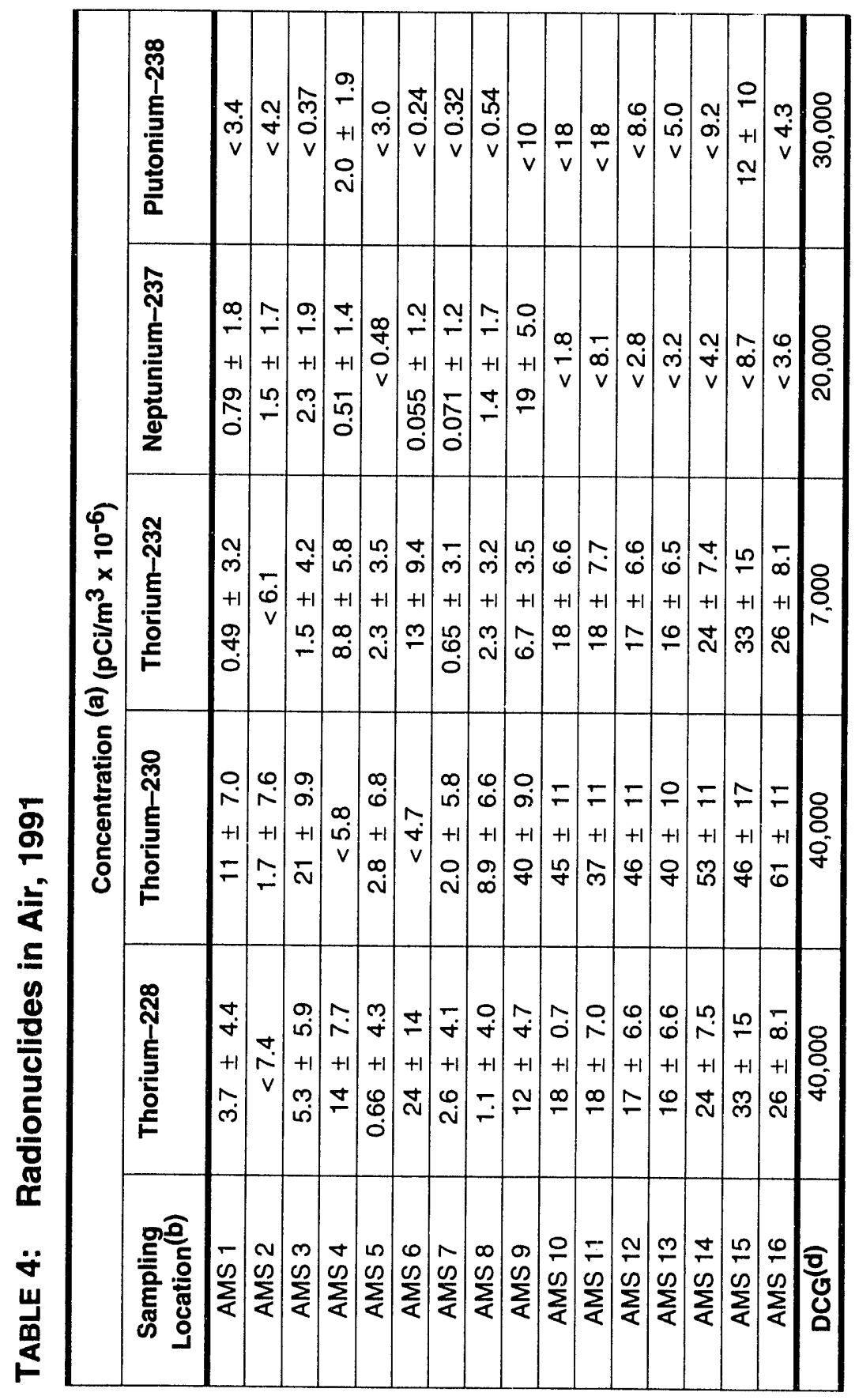


0
4
0
0
0
0
0

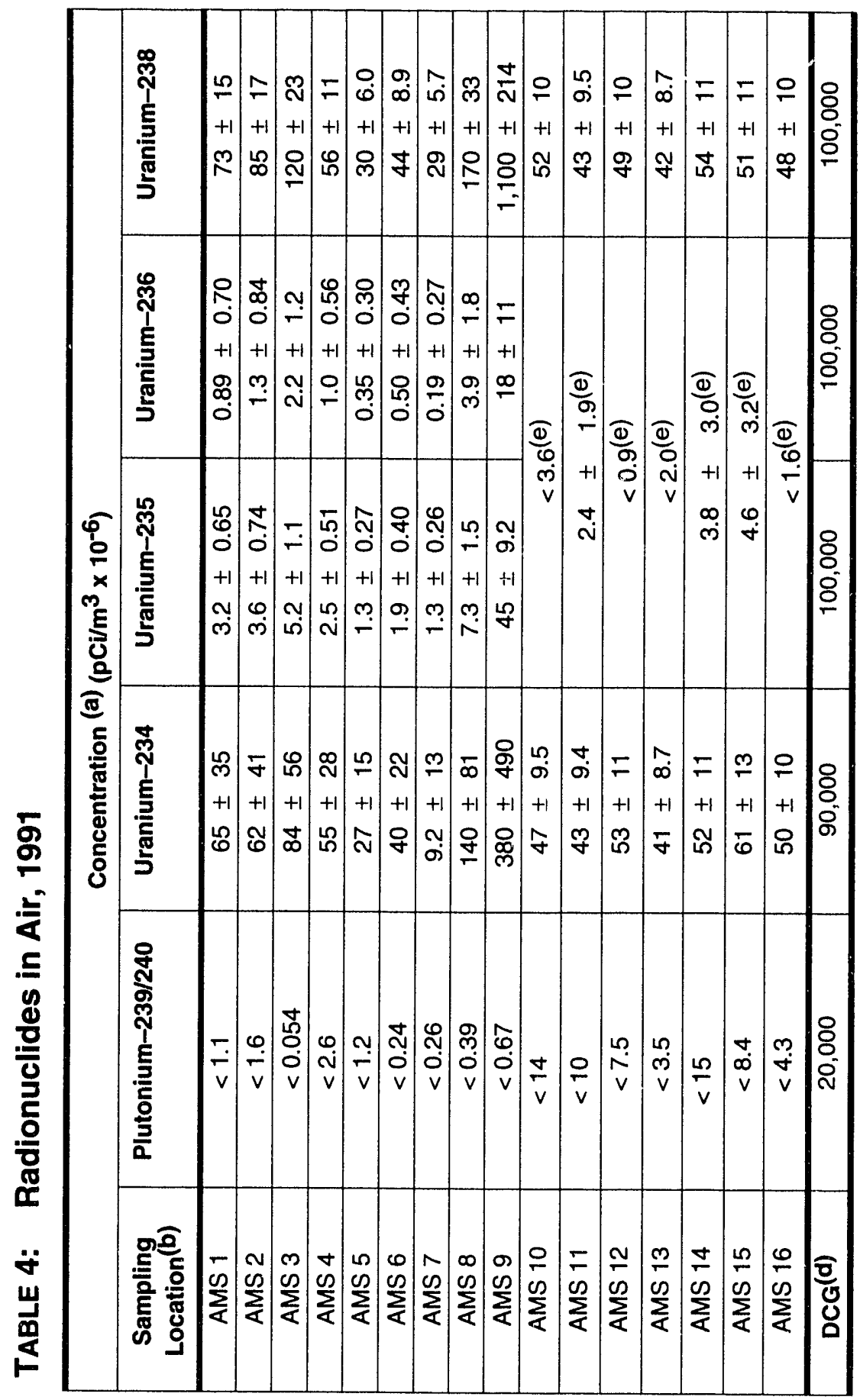


0
0
0
0
8
8
8

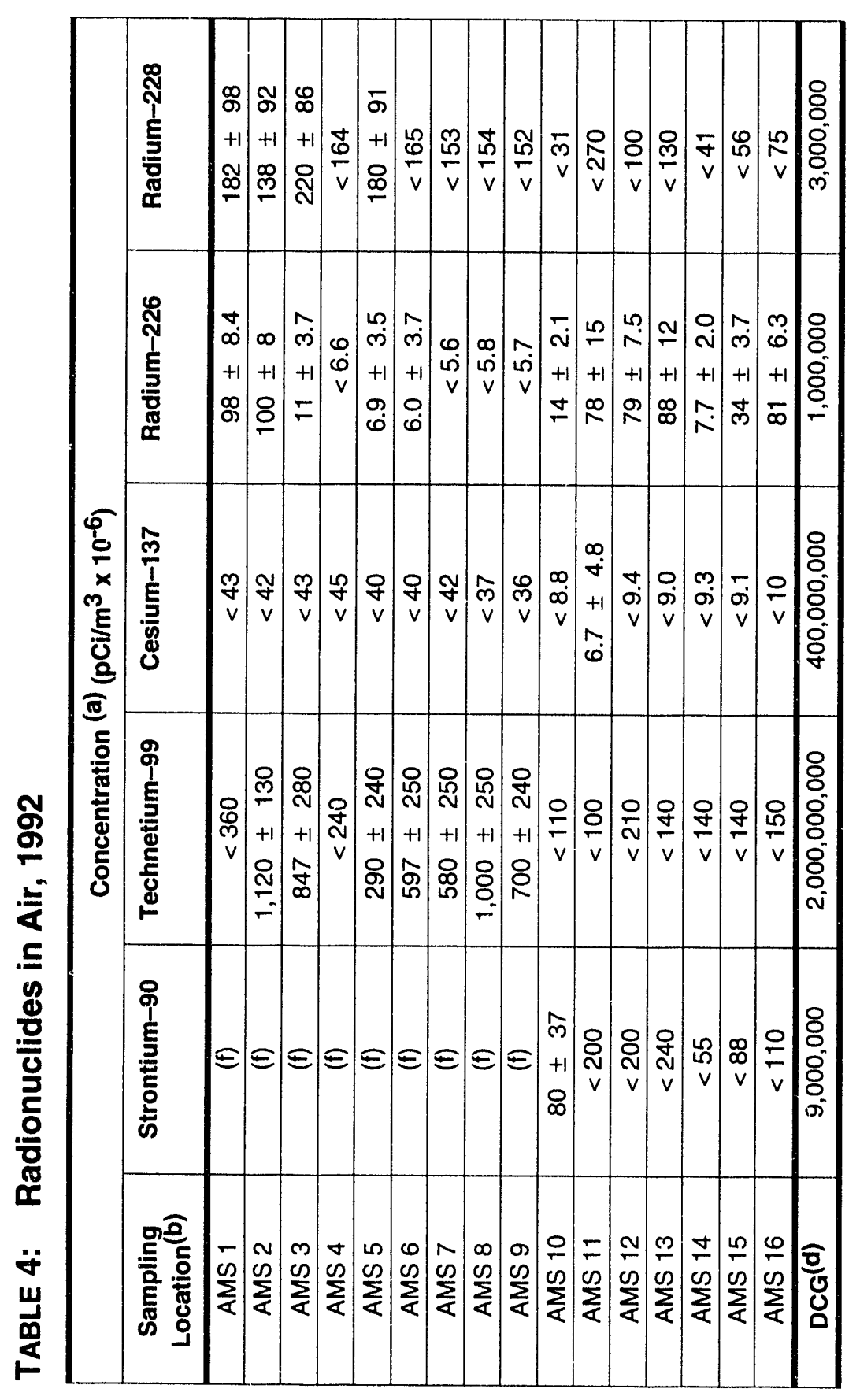


0
0
10
0
0
0
0

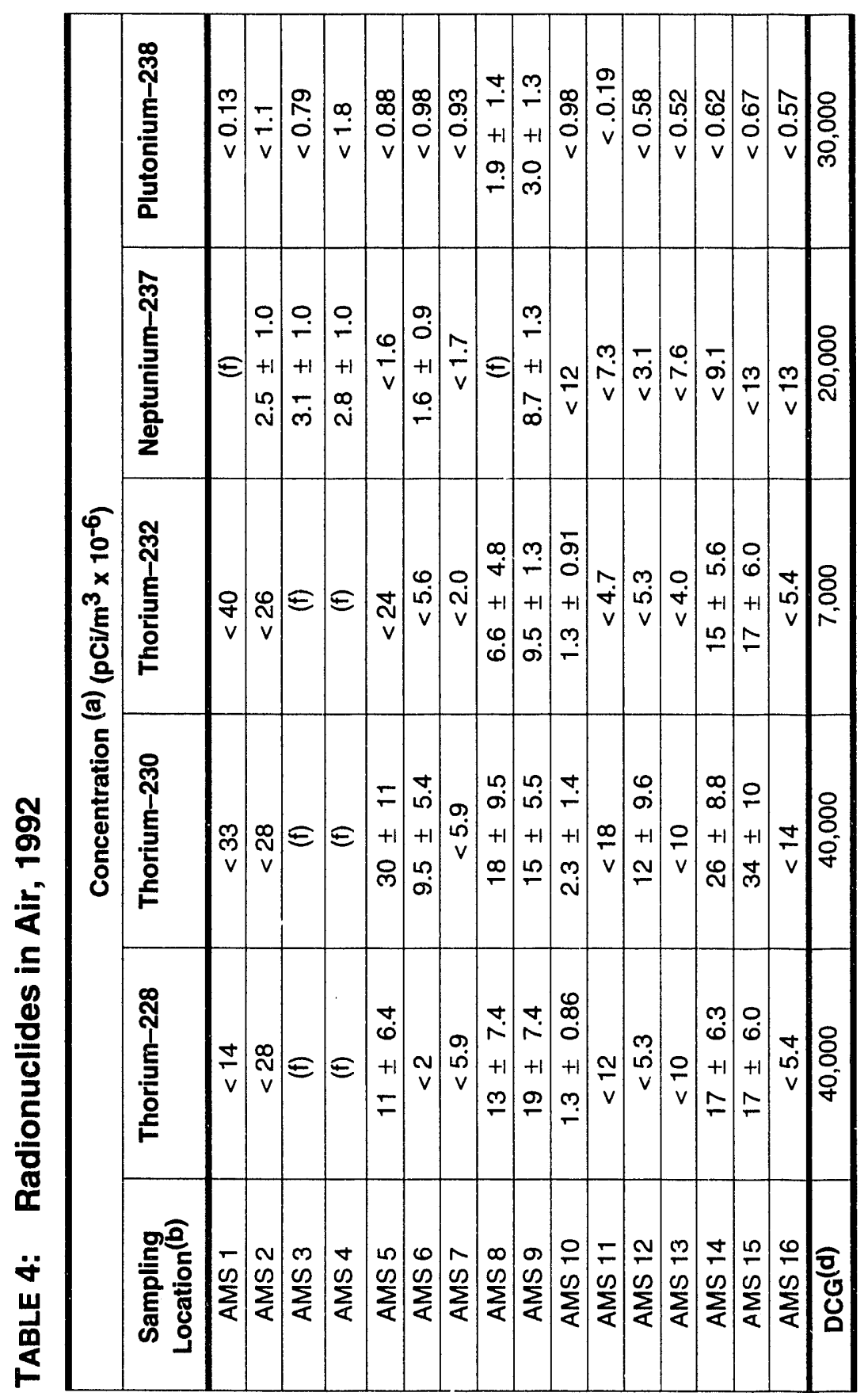


0
$\div 0$
0
0
0
8
0
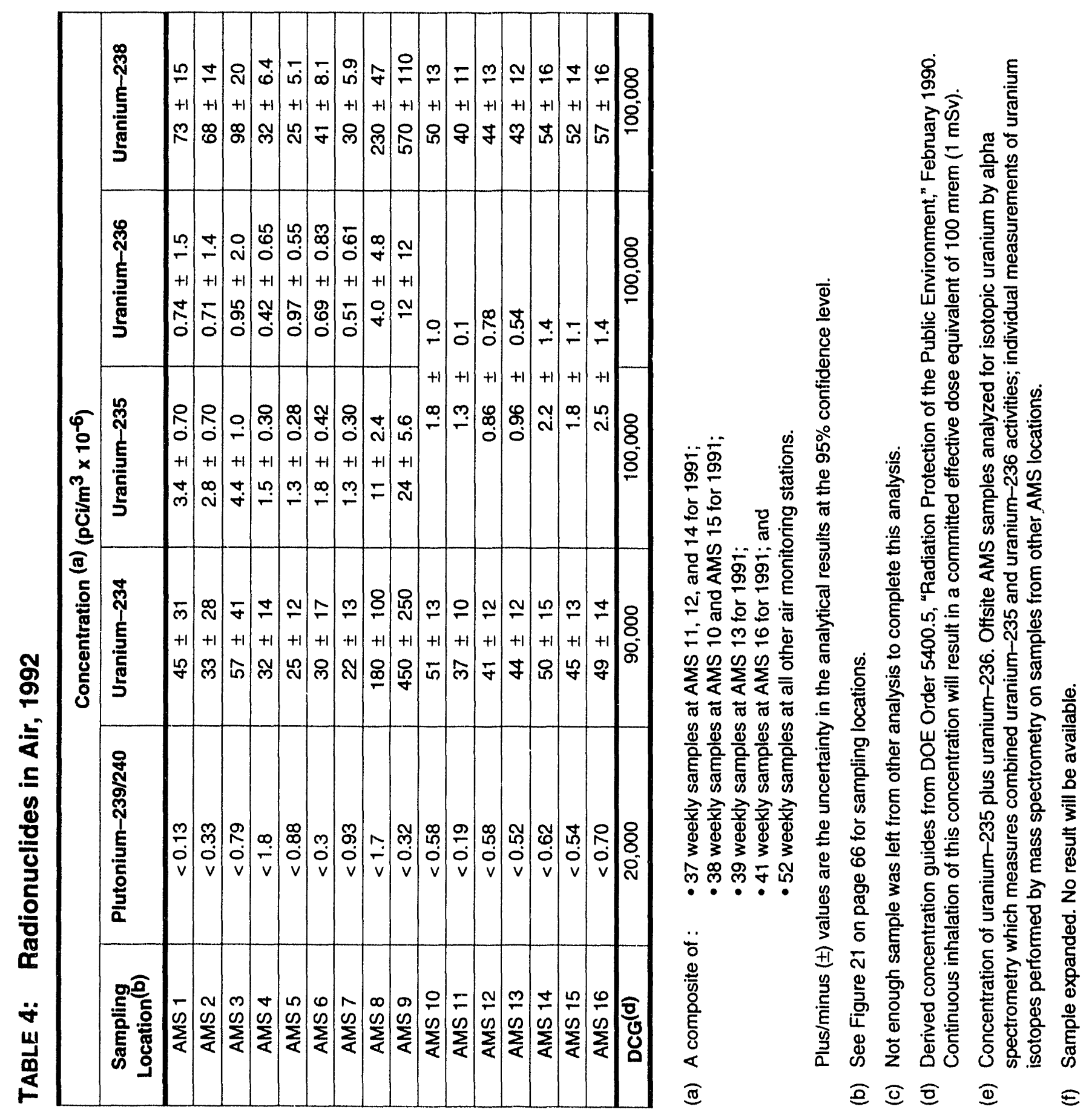


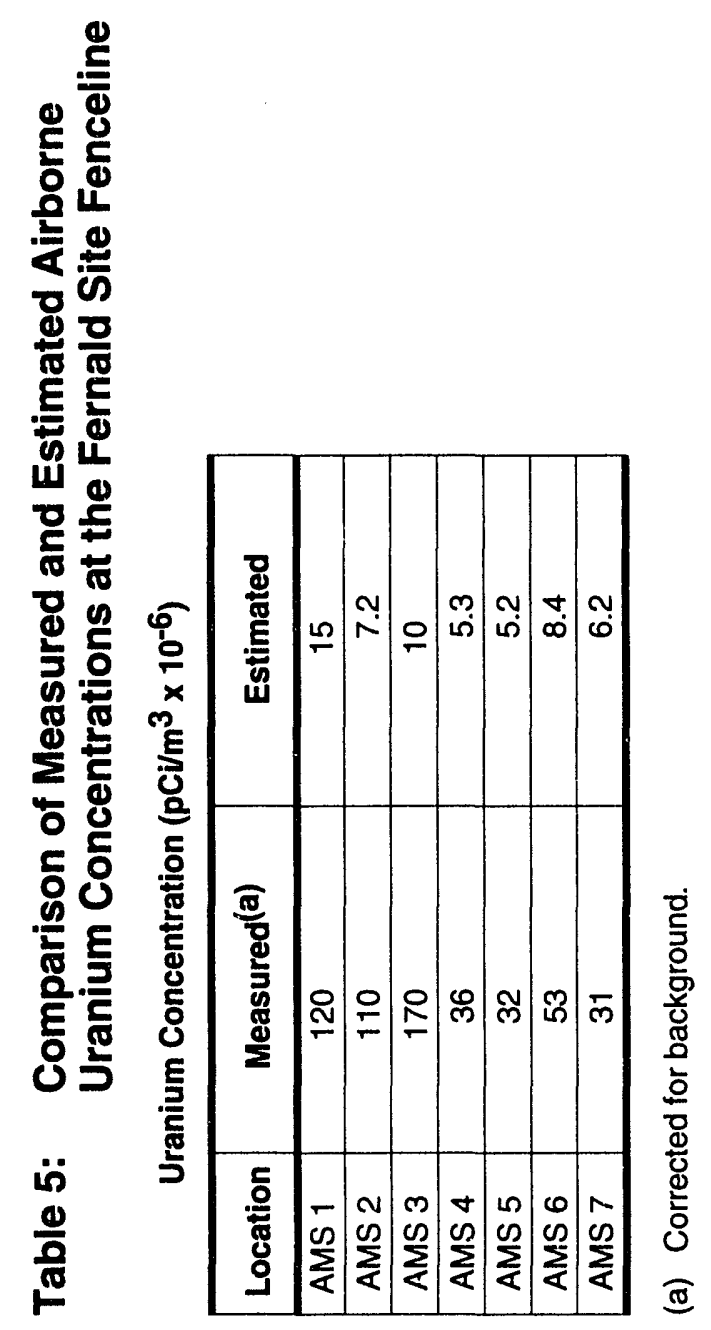



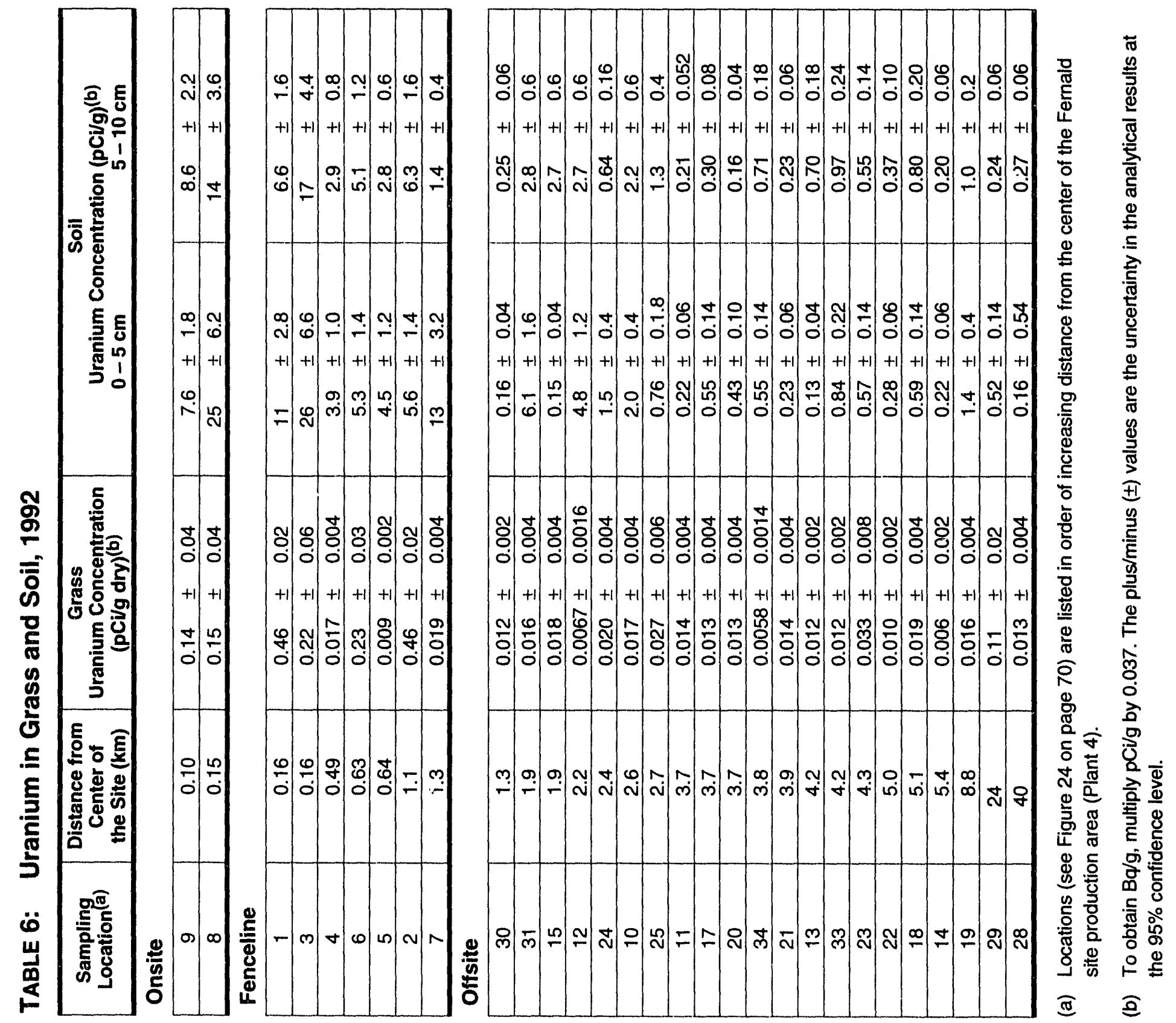
$\frac{N}{0}$
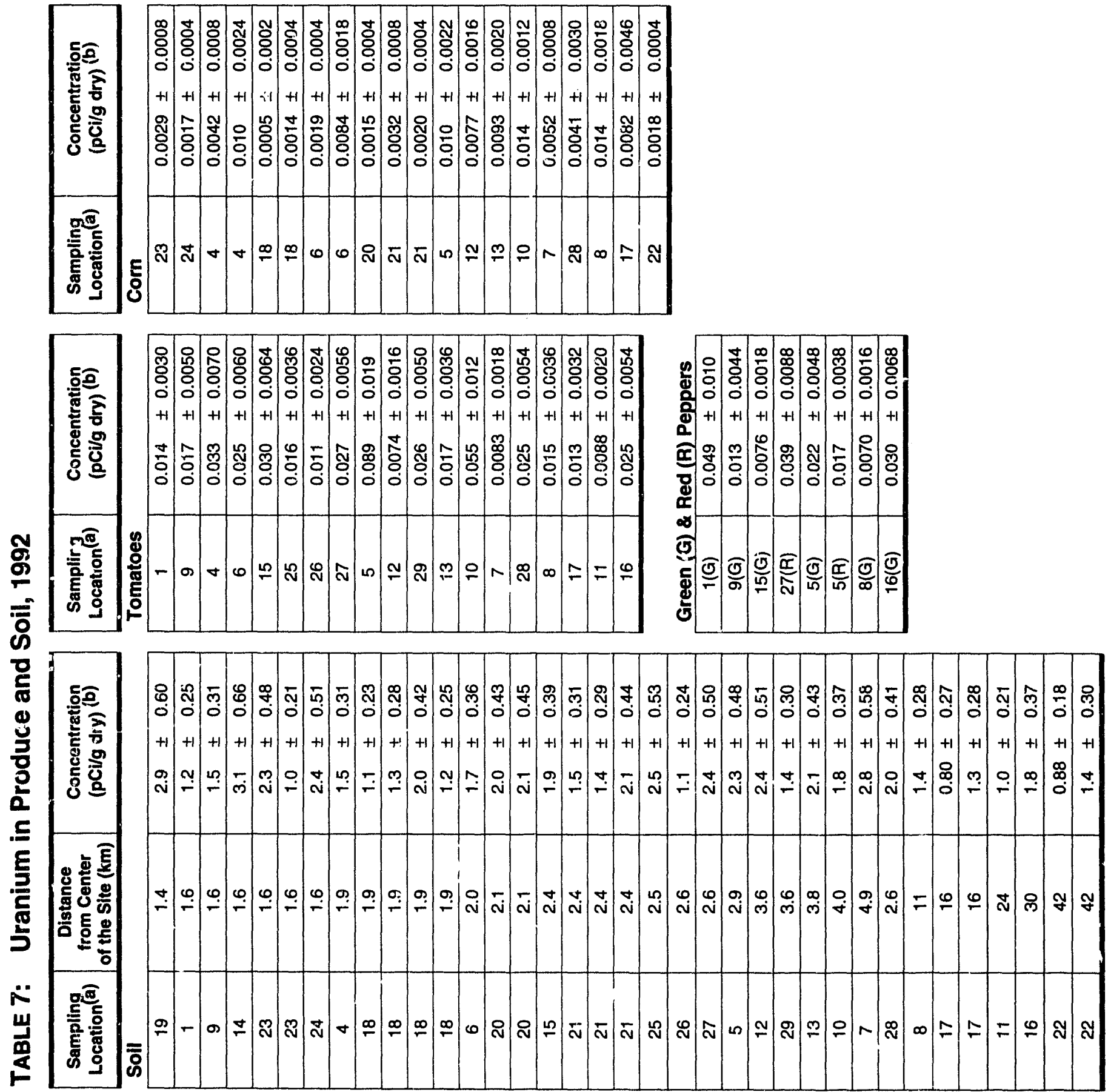


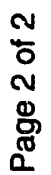

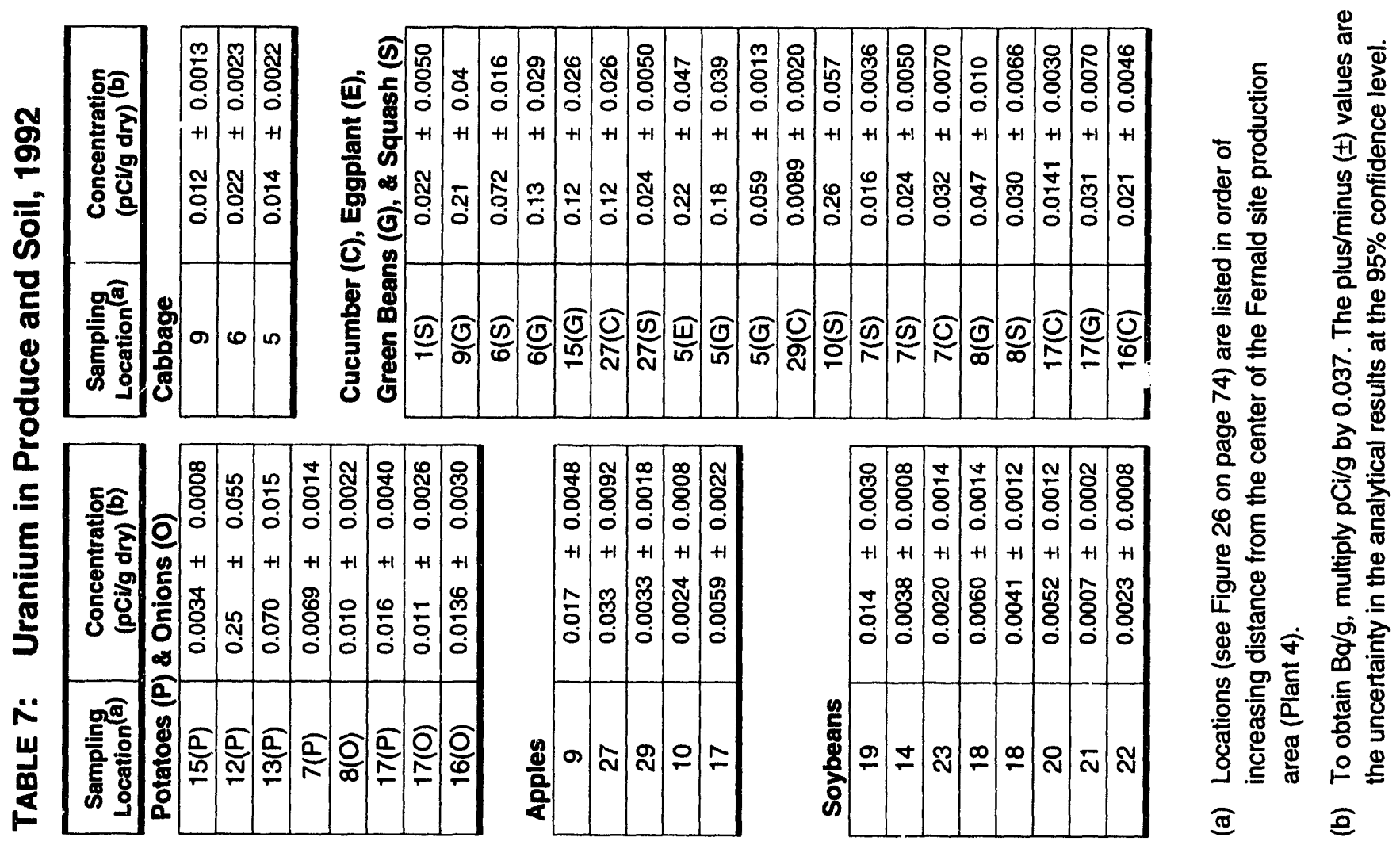




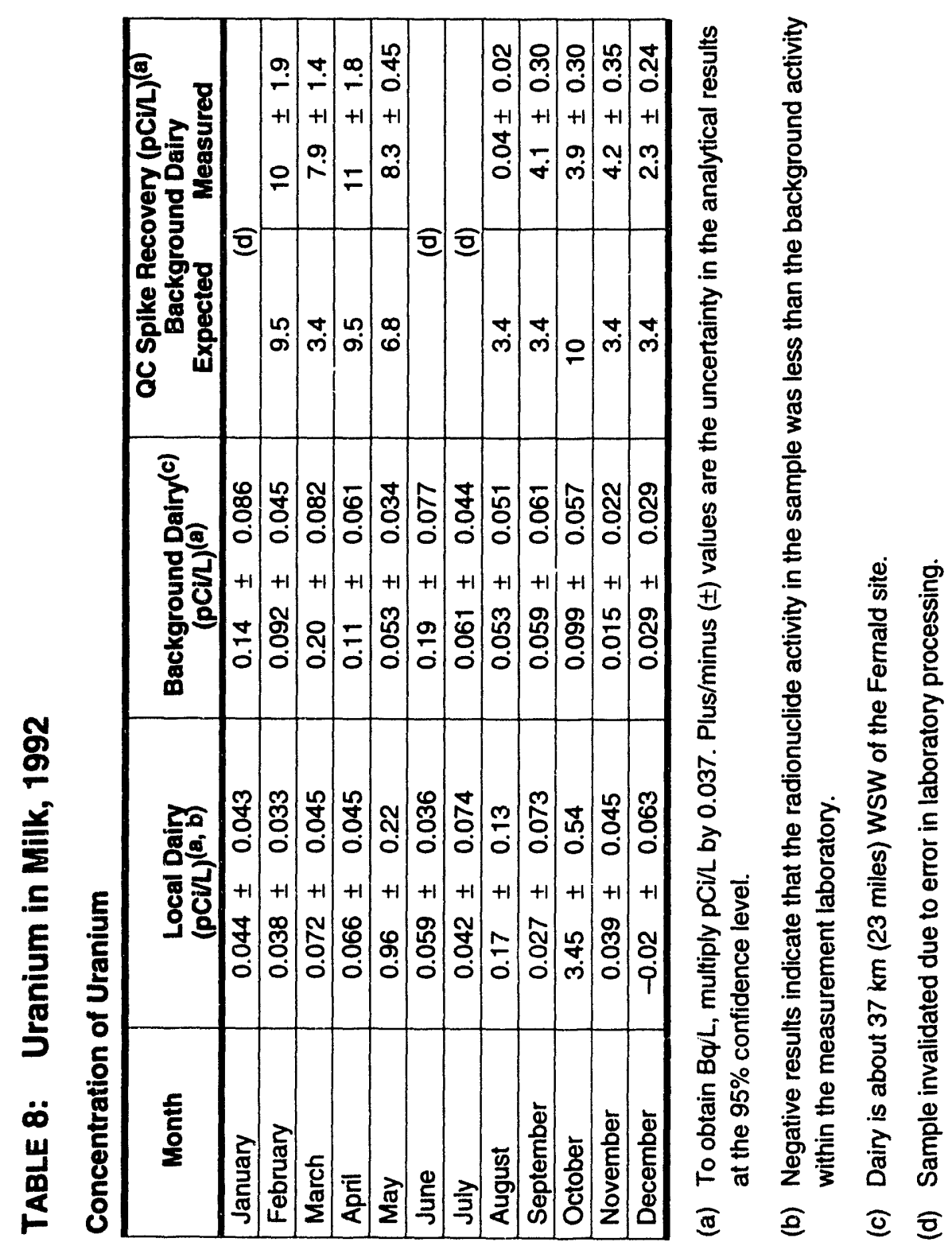




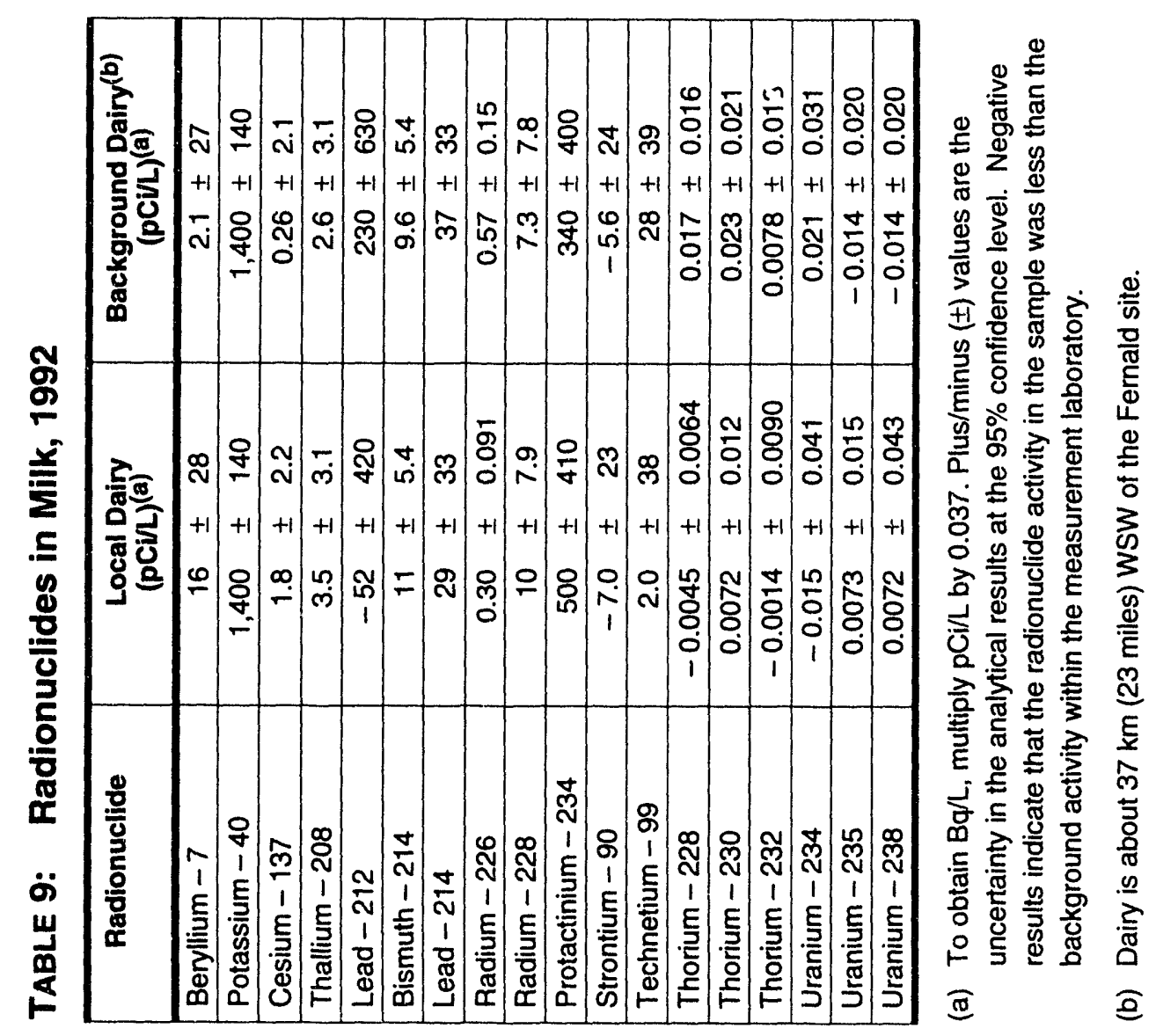




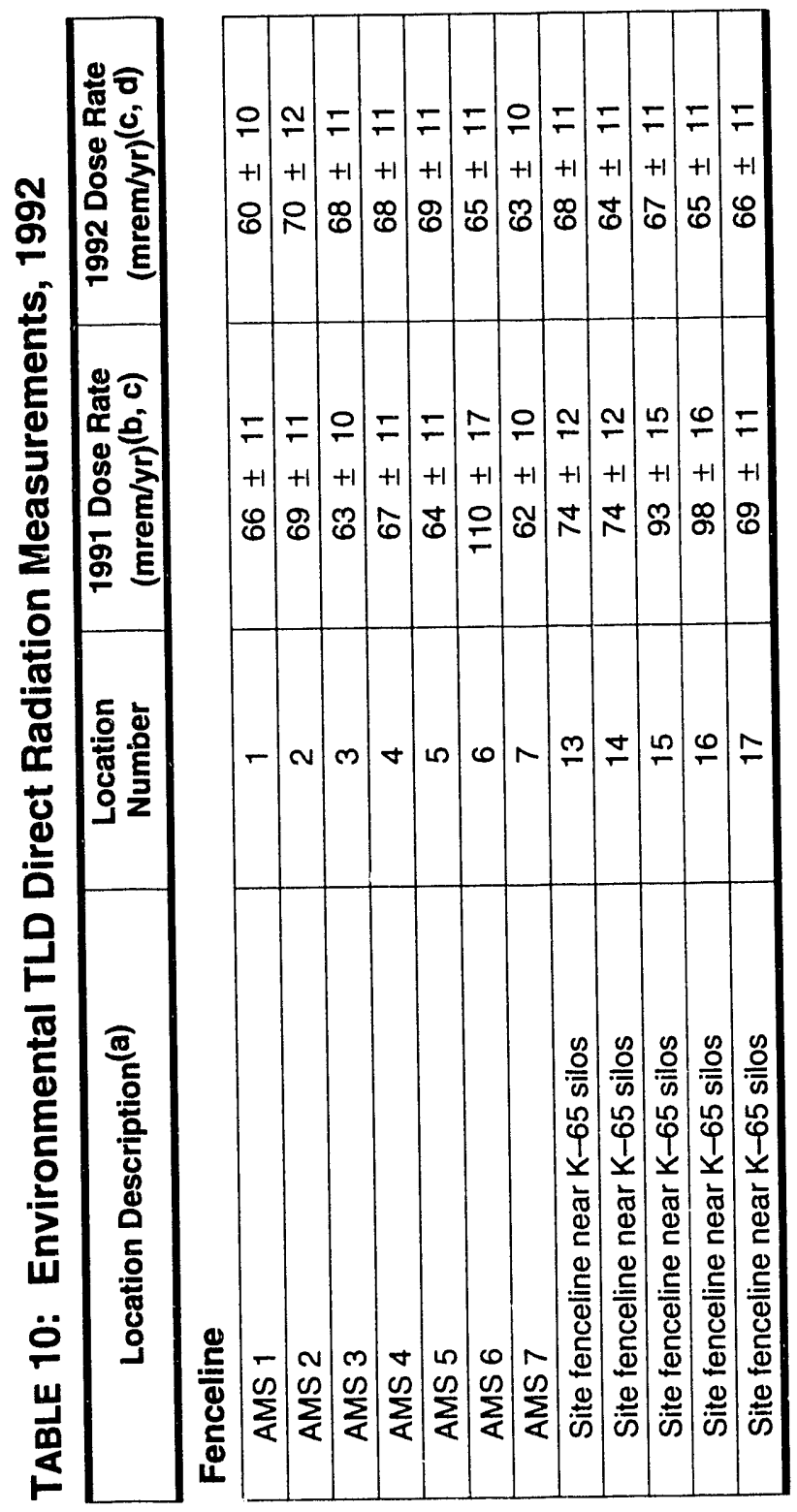

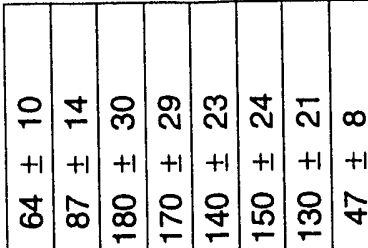

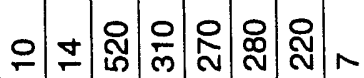
$+1+1+1+1+1+1+1$

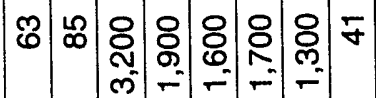
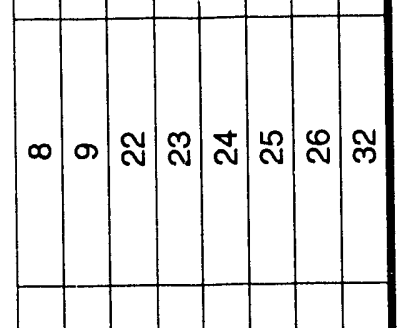

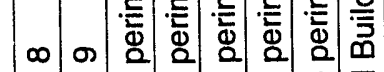

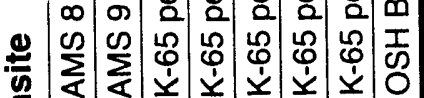

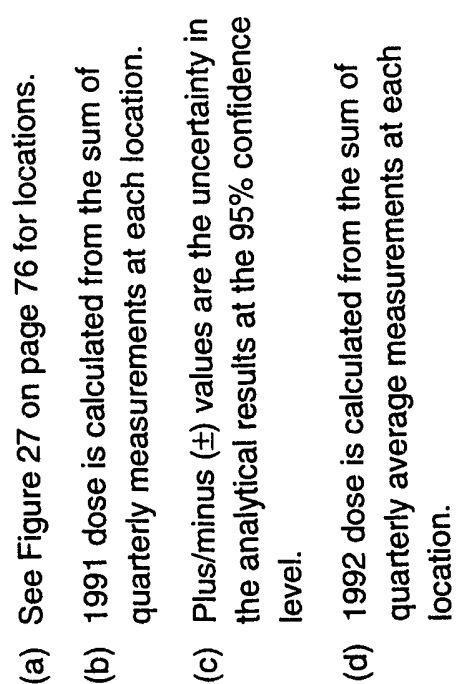

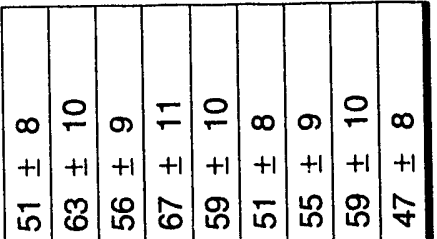

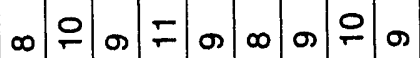
$+1+1+1+1+1+1+1$ 员

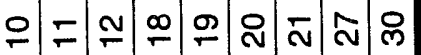

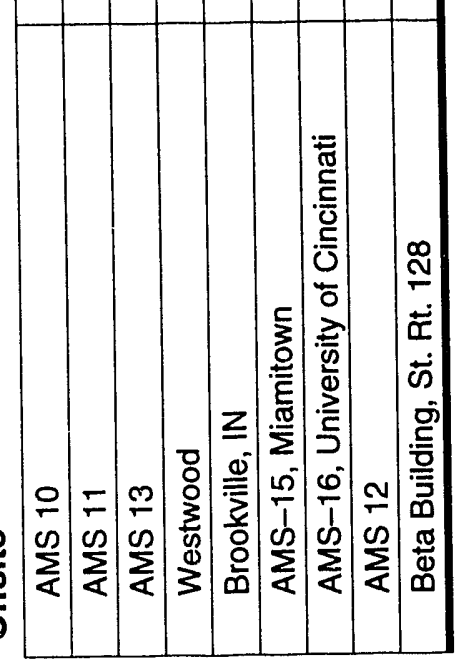




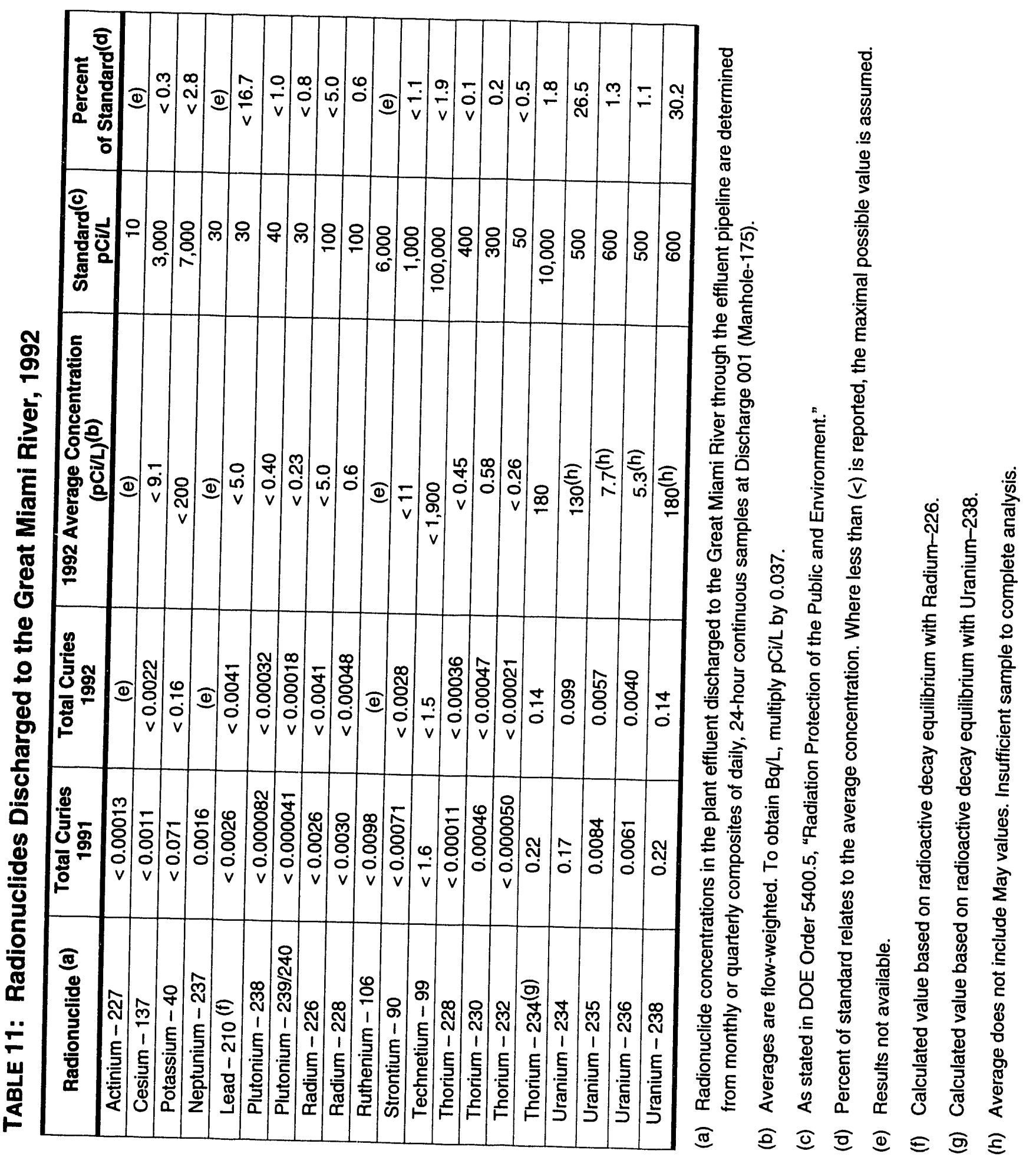




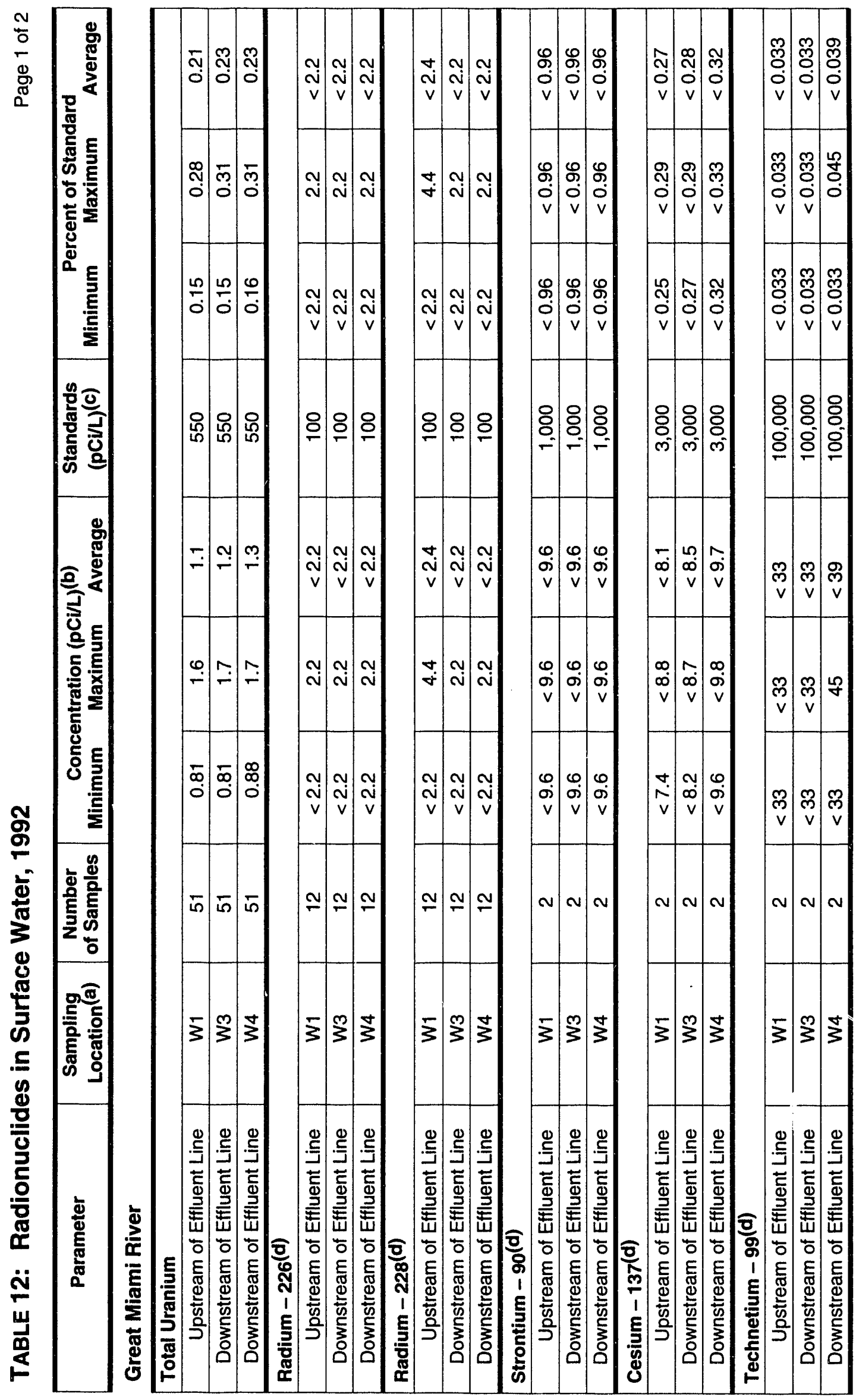




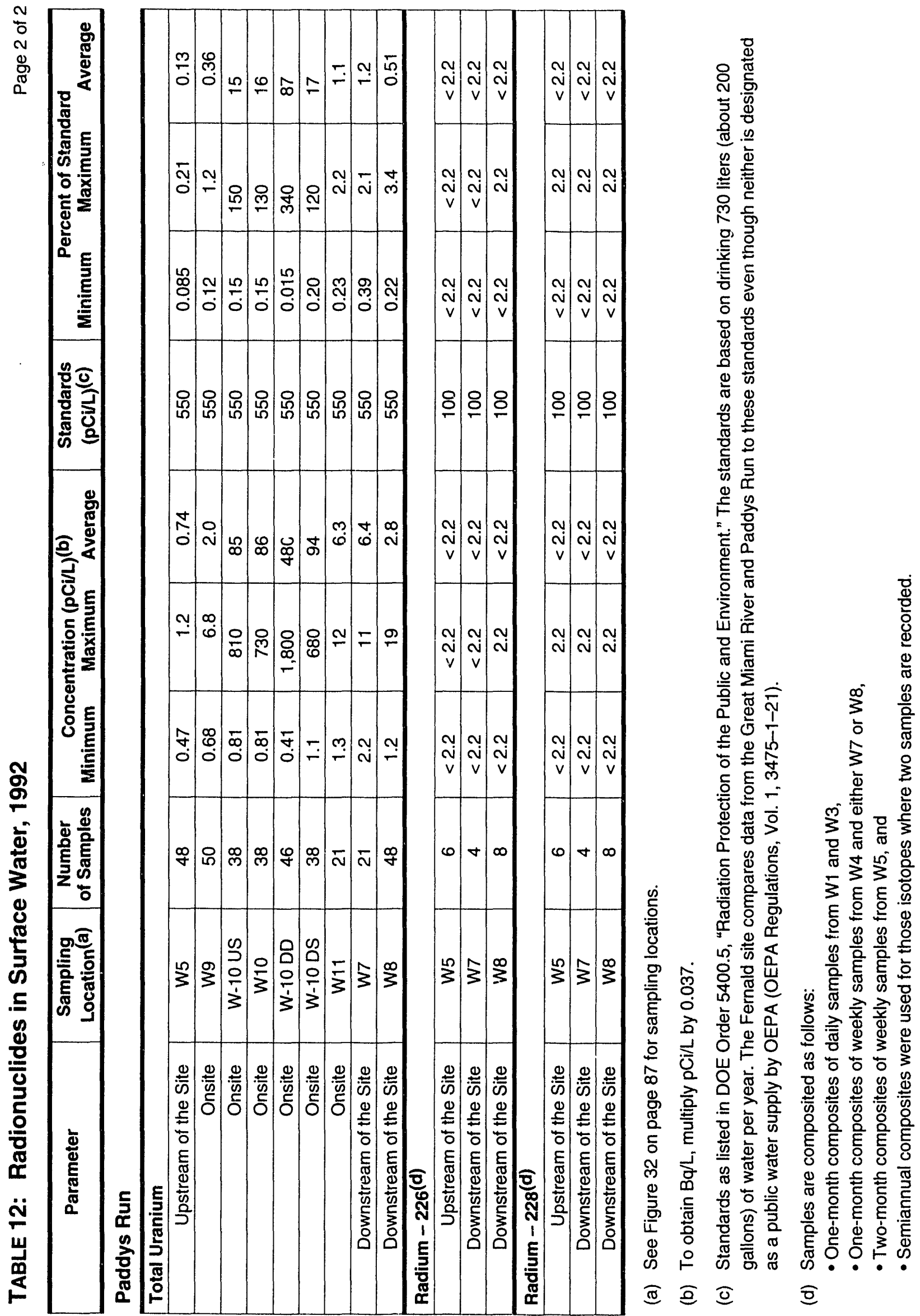




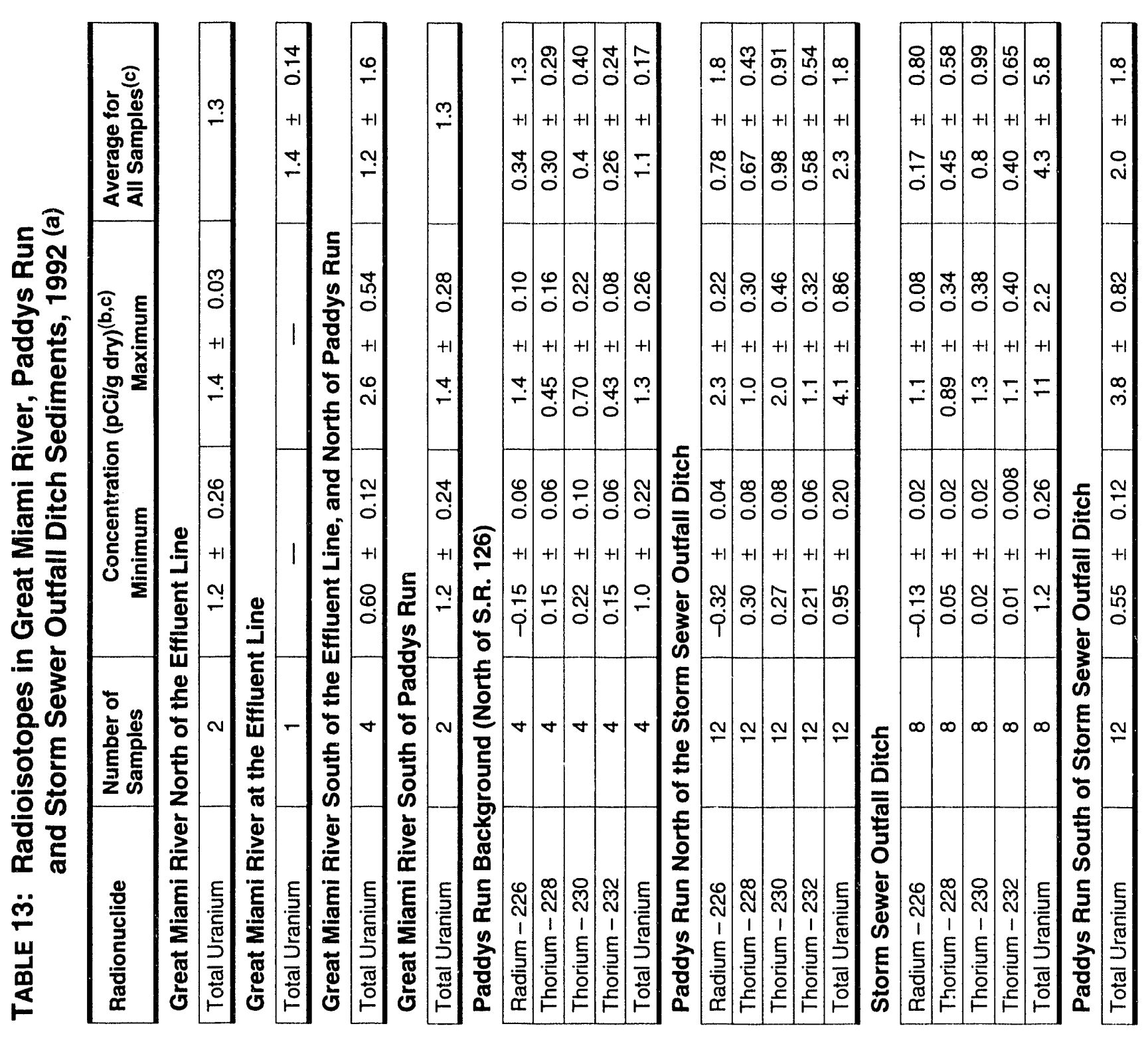




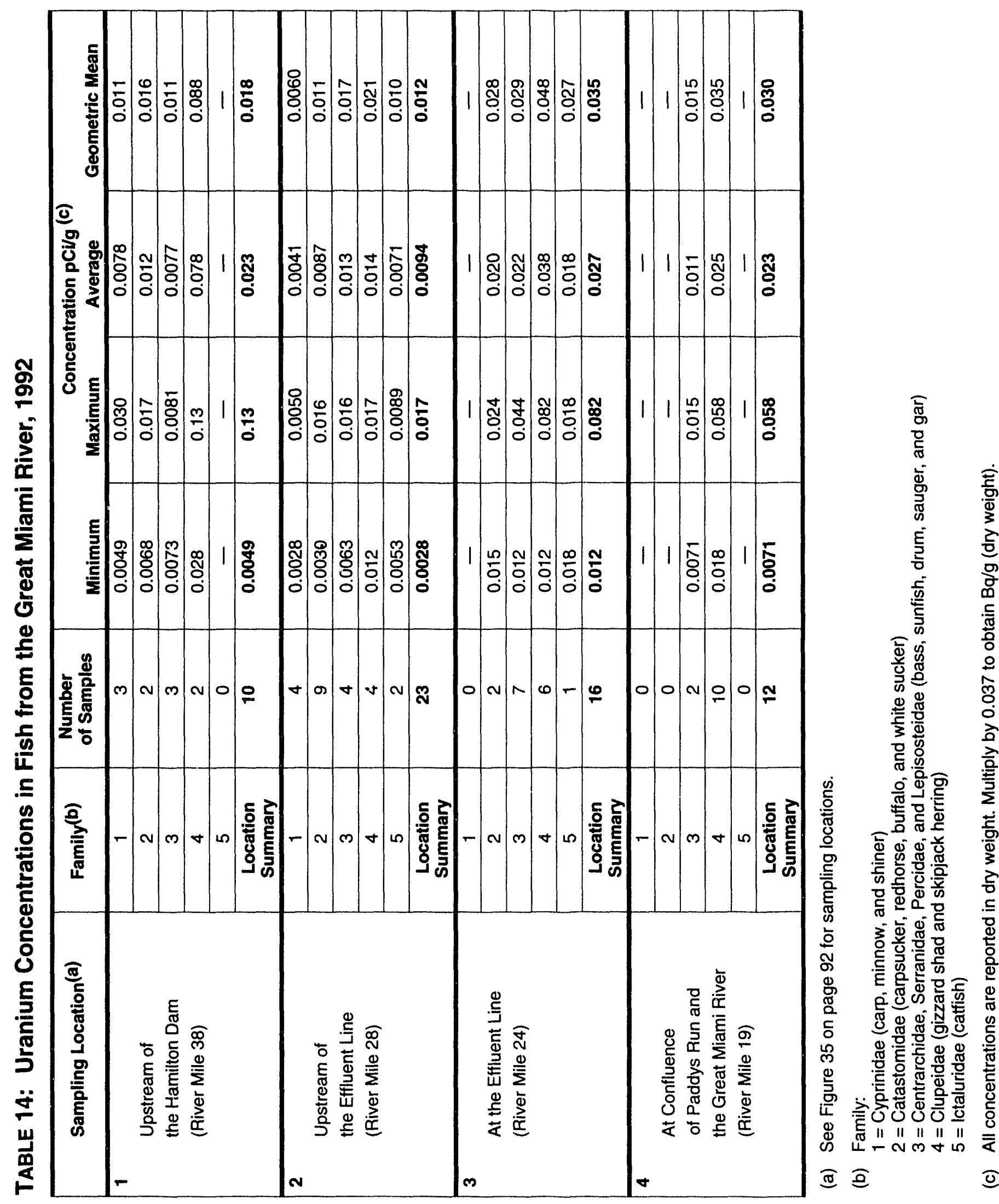




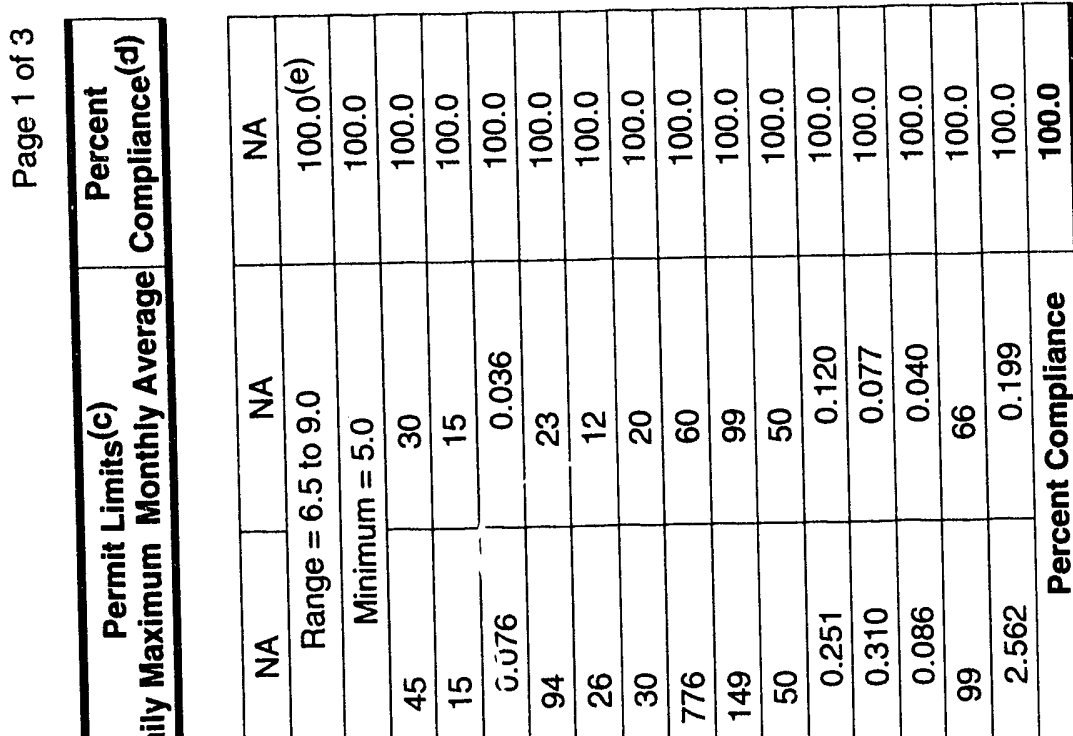

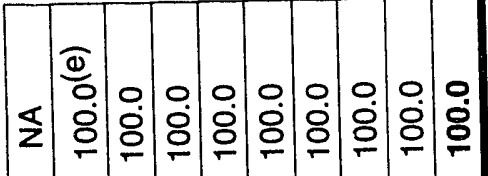

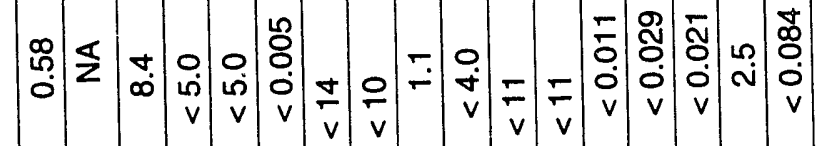

을

ํㅗㅀ

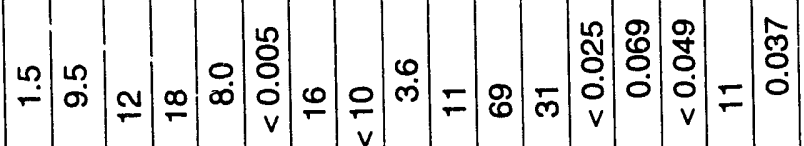

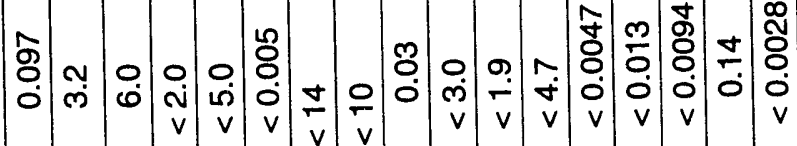

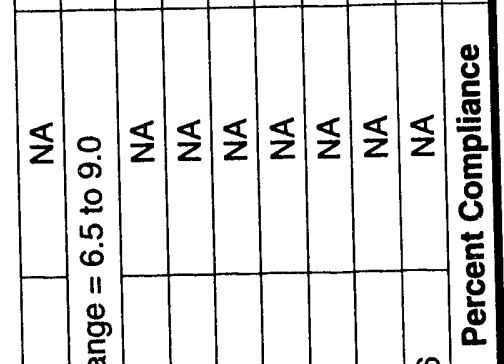

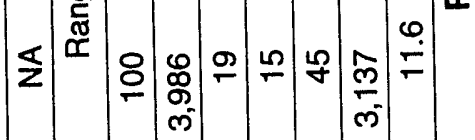

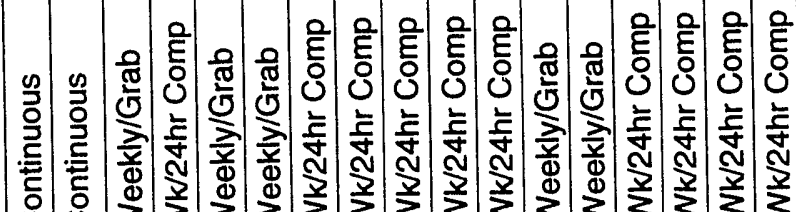

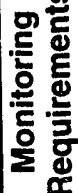

j.

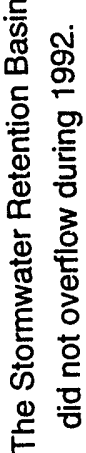

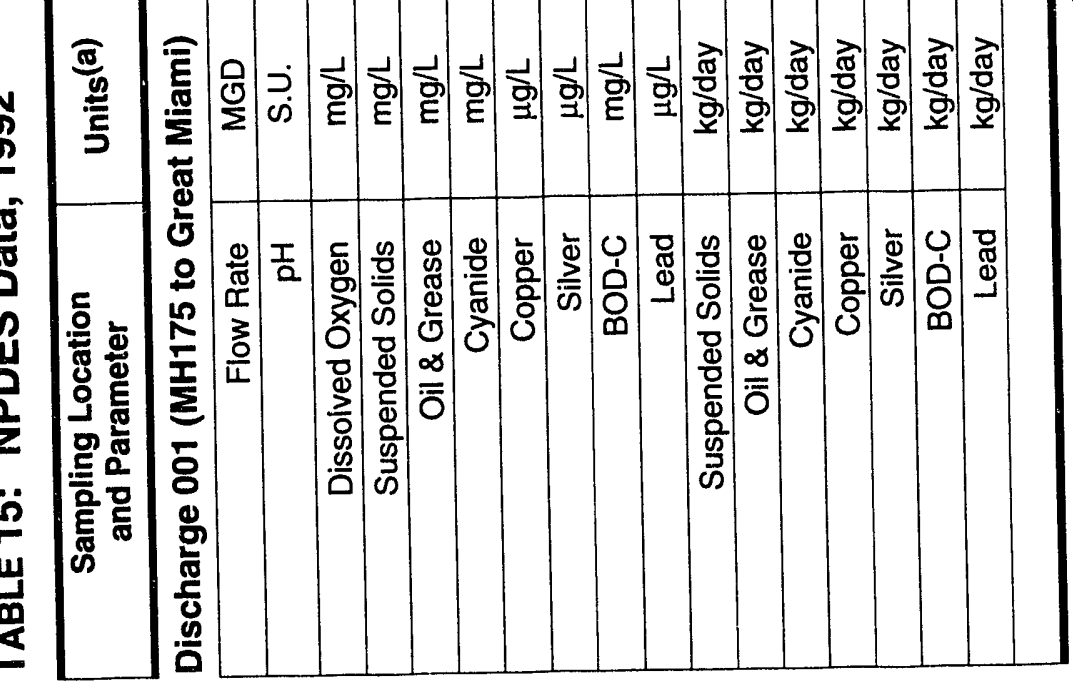

돌

일 है है

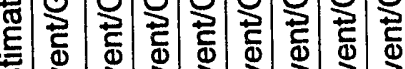

岃岀岀岀岀岀

要

号它

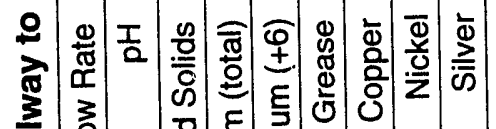

言

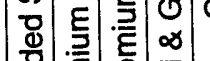

总

ชิ

के 


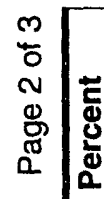
훙 ठ

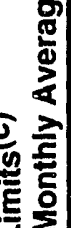

है

a.

촗

อิ

巡

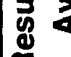

空

을

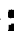

층

产

窟
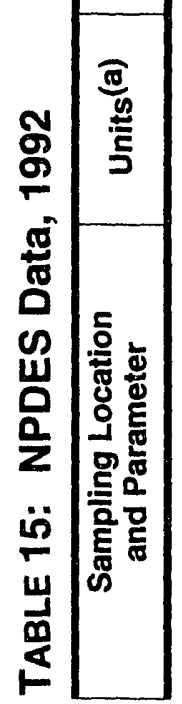

$\operatorname{lng} 2$

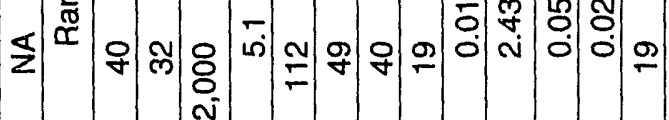

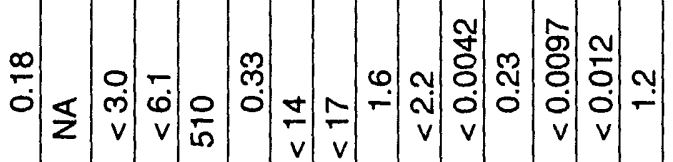

뚱요의

$0=\frac{0}{\omega}=-\frac{V}{v}=0.0000$

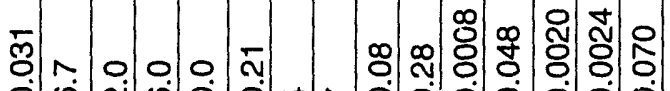

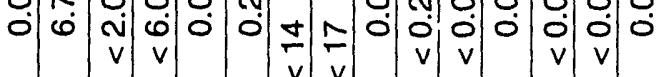

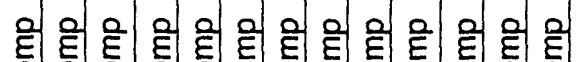
\%

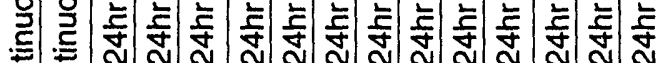
ठํ.

空

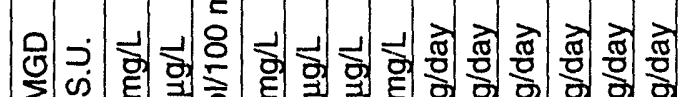

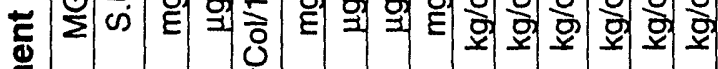

(⿻)

는
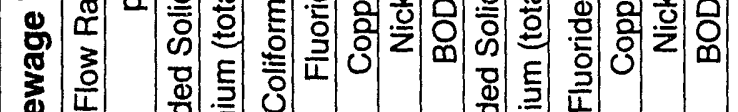

क

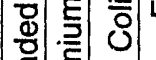

政

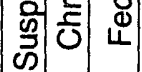

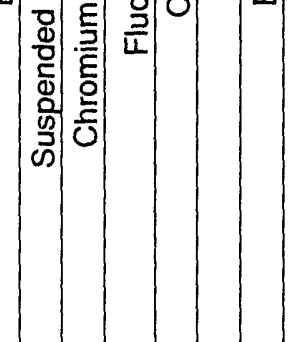

๔

느의의의의의의의우은

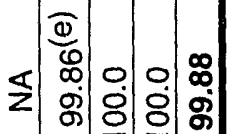

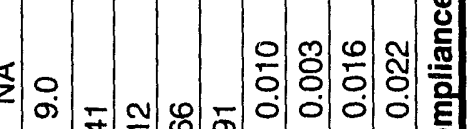

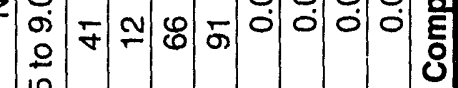

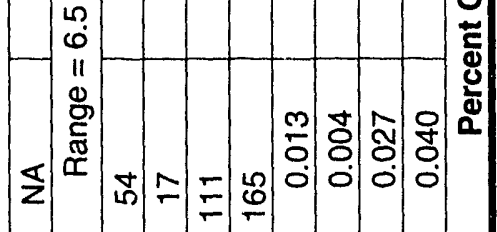

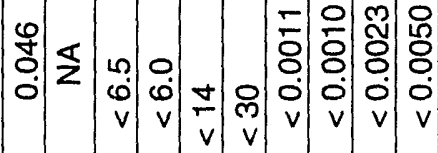

ㄴ.

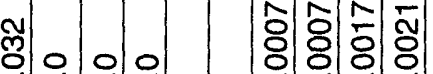

$\therefore$ :

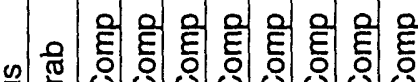

要

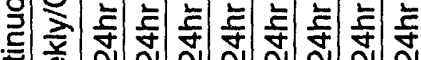

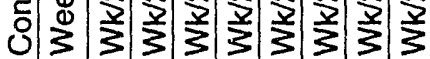

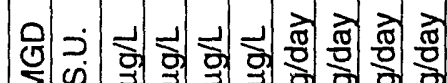
화혀 호웅

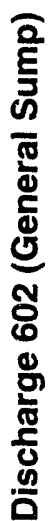

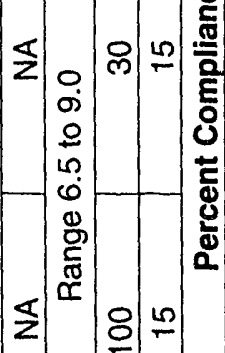

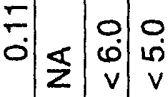

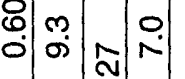

음

항 ڤิ $v \vee$

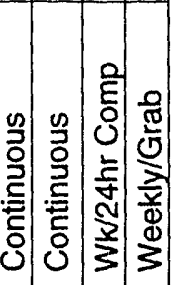

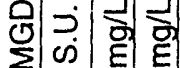

政
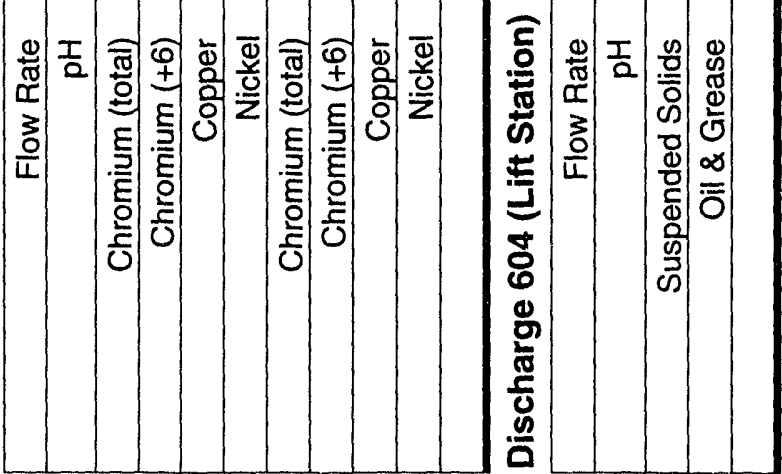


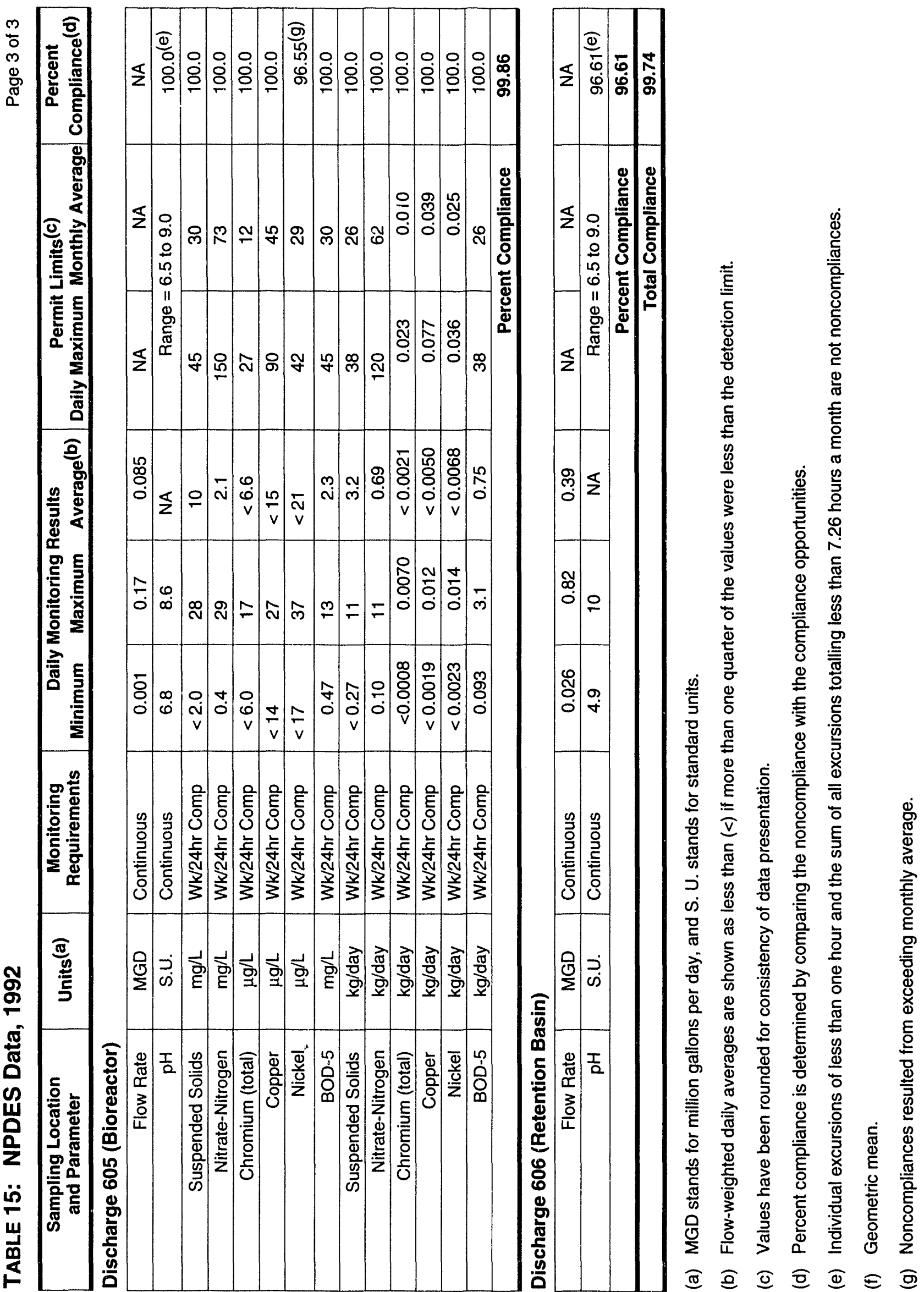




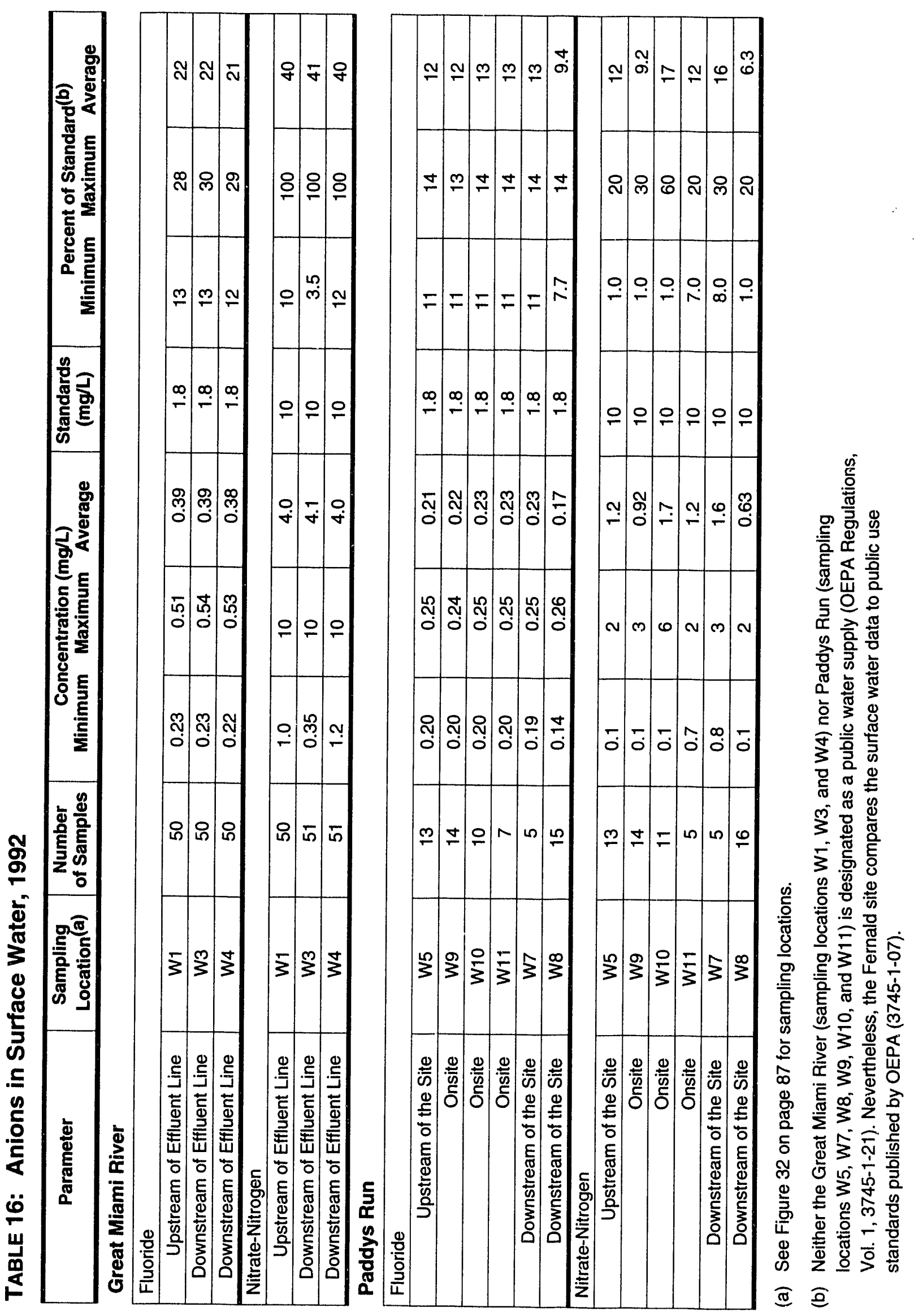




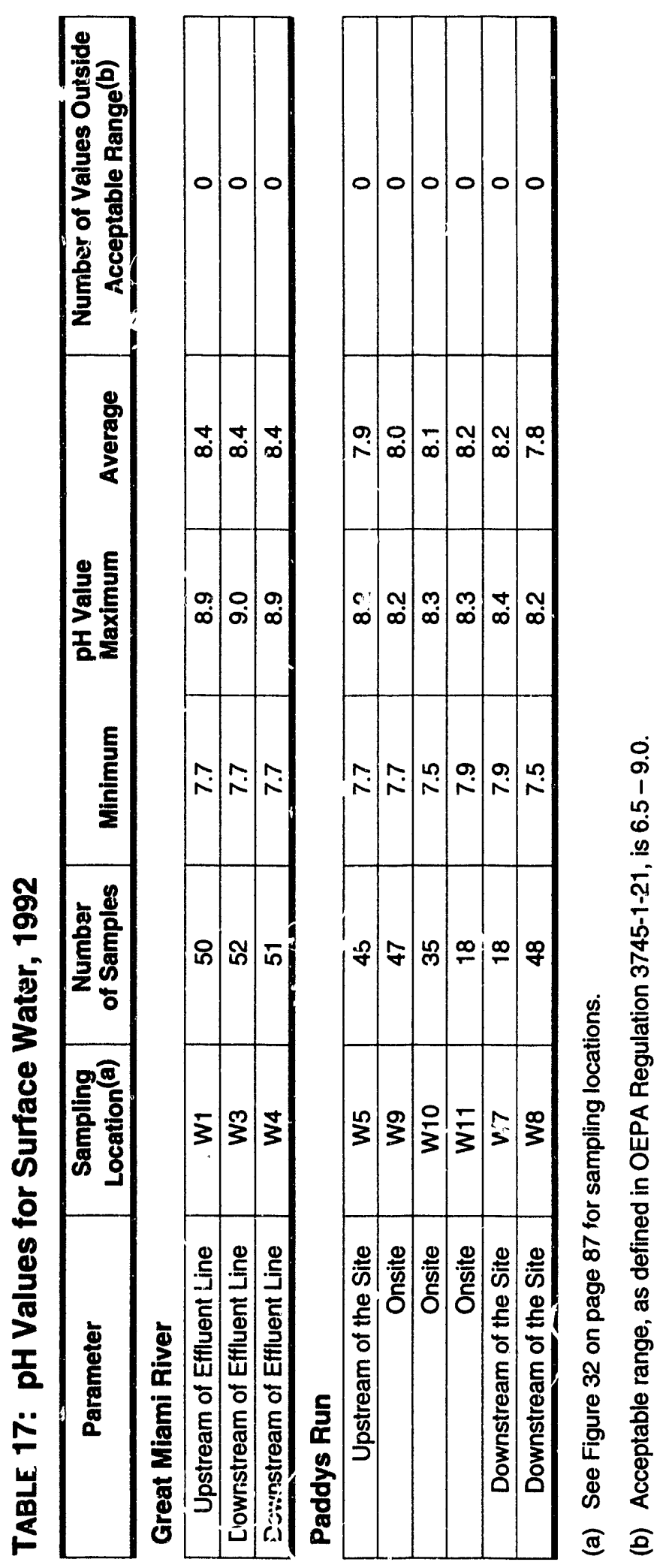




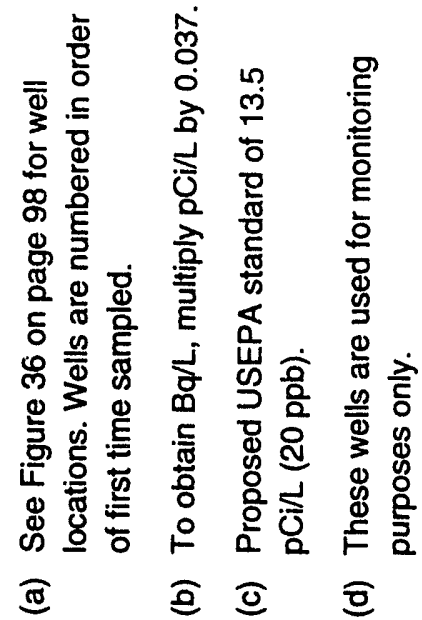

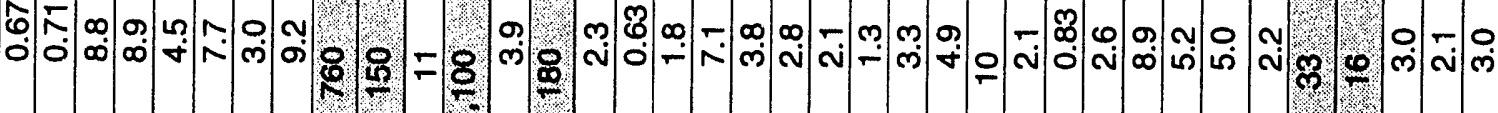
1.1 .

(

落

\%

\&

¿ E 를

gㅇำ $\sim$ ธ⿺辶一 -

บ $-\mathrm{s} 8$

$\because \pi \frac{n}{0}$

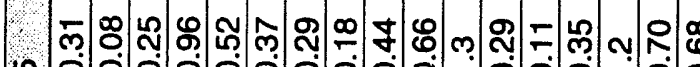

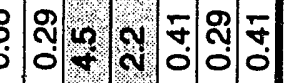

$\underbrace{}_{0}$

을 틀.

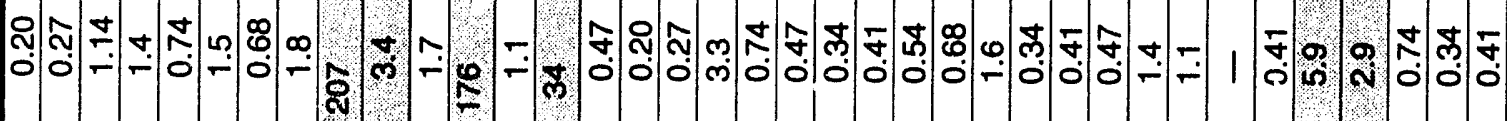

(1)

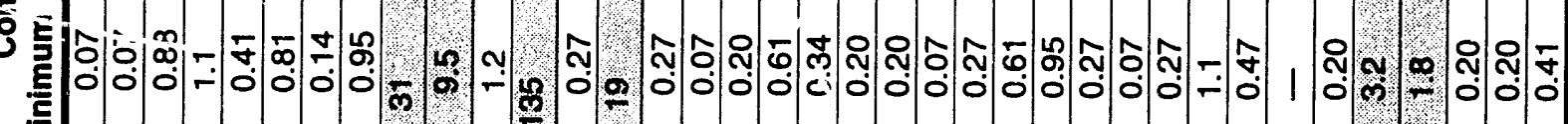

든

통

g

要

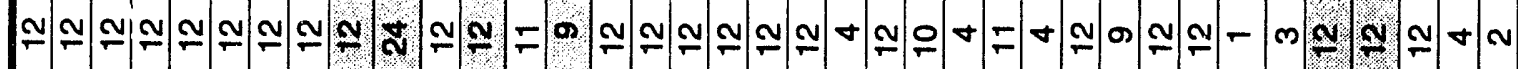

ळ̊

状

$\overline{\frac{\Phi}{0}}$

$-m+n \infty 0 \div 0 \div$

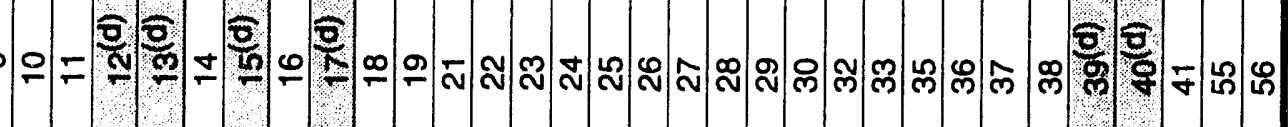




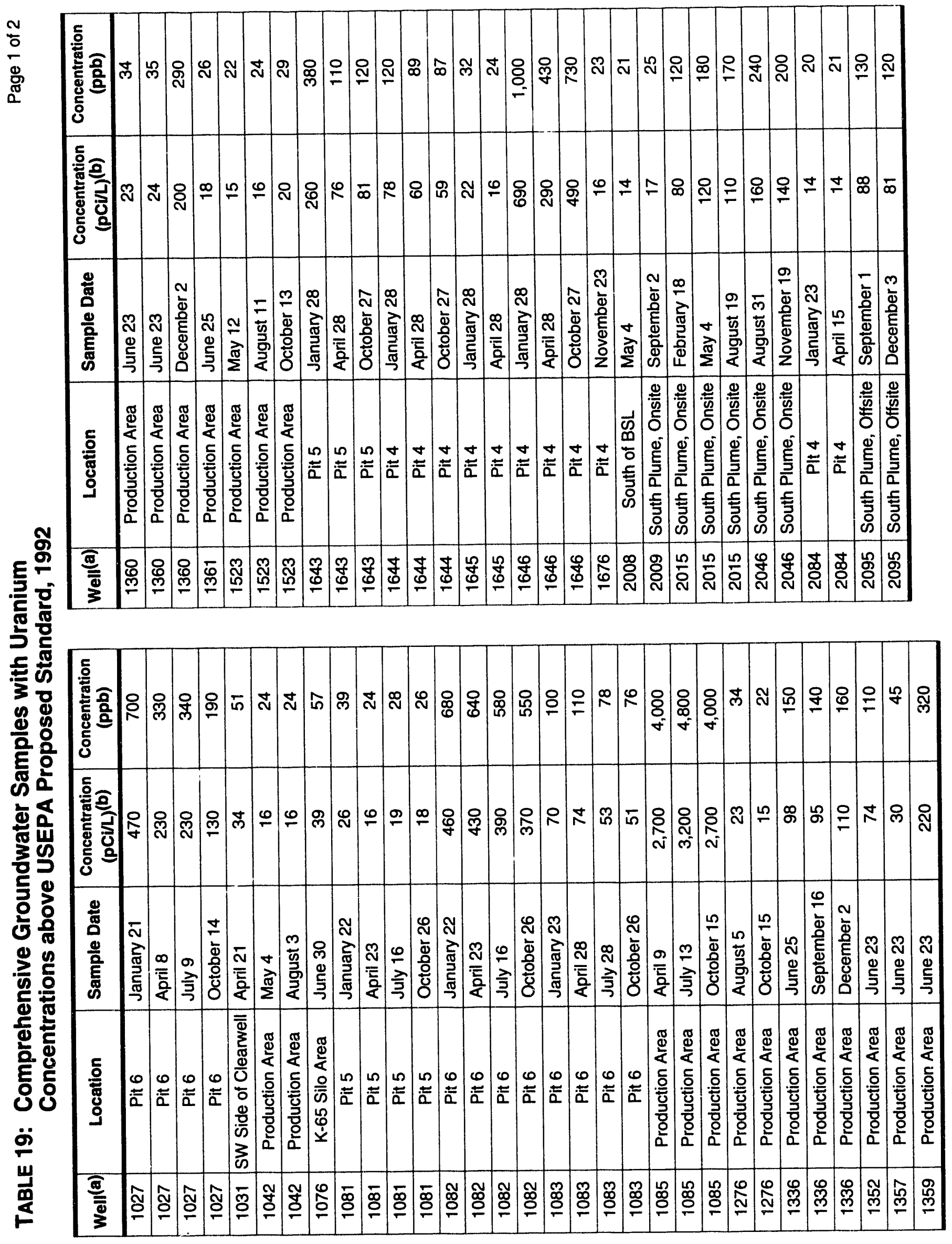




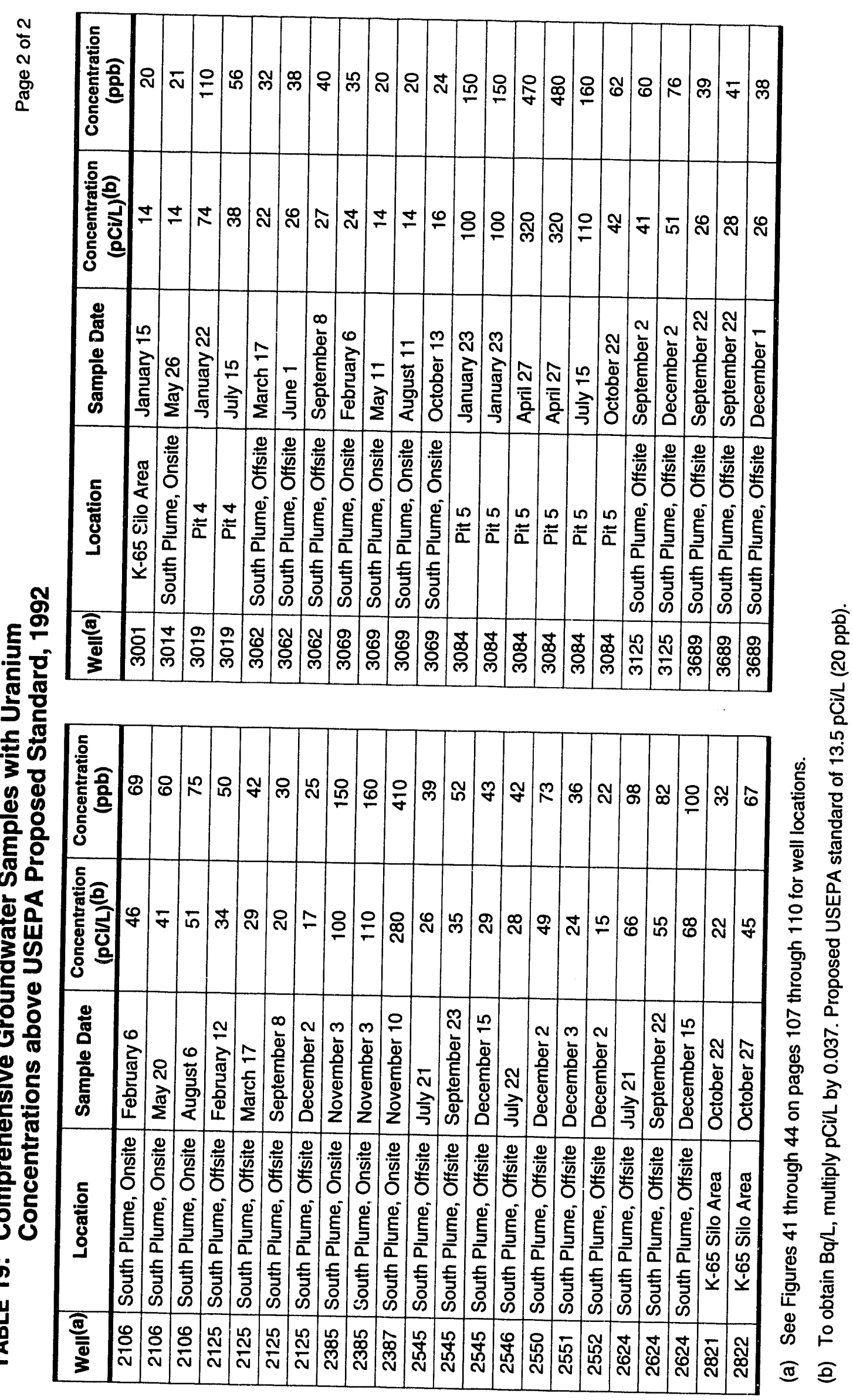




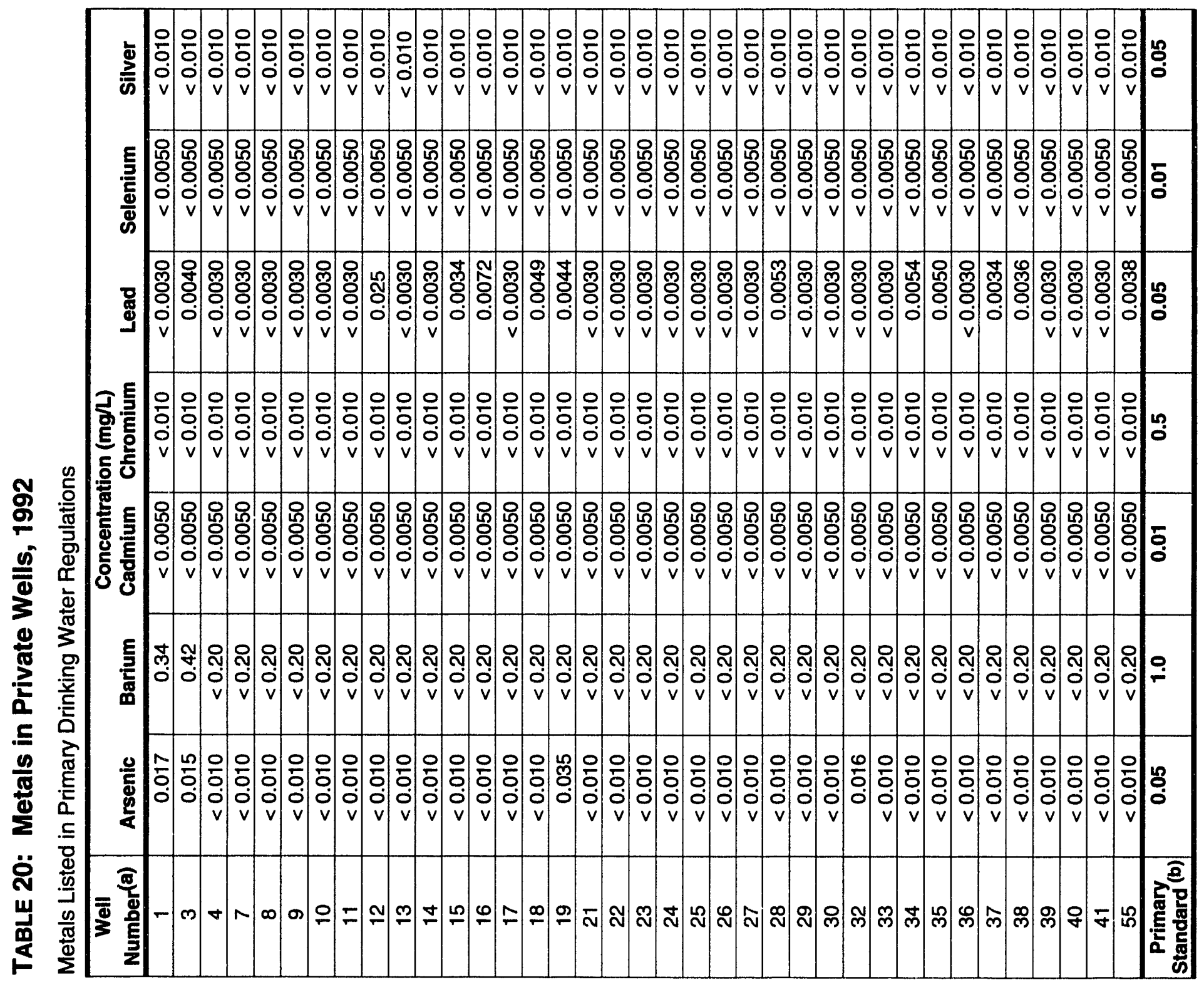


3
o
v
0
0
0
0

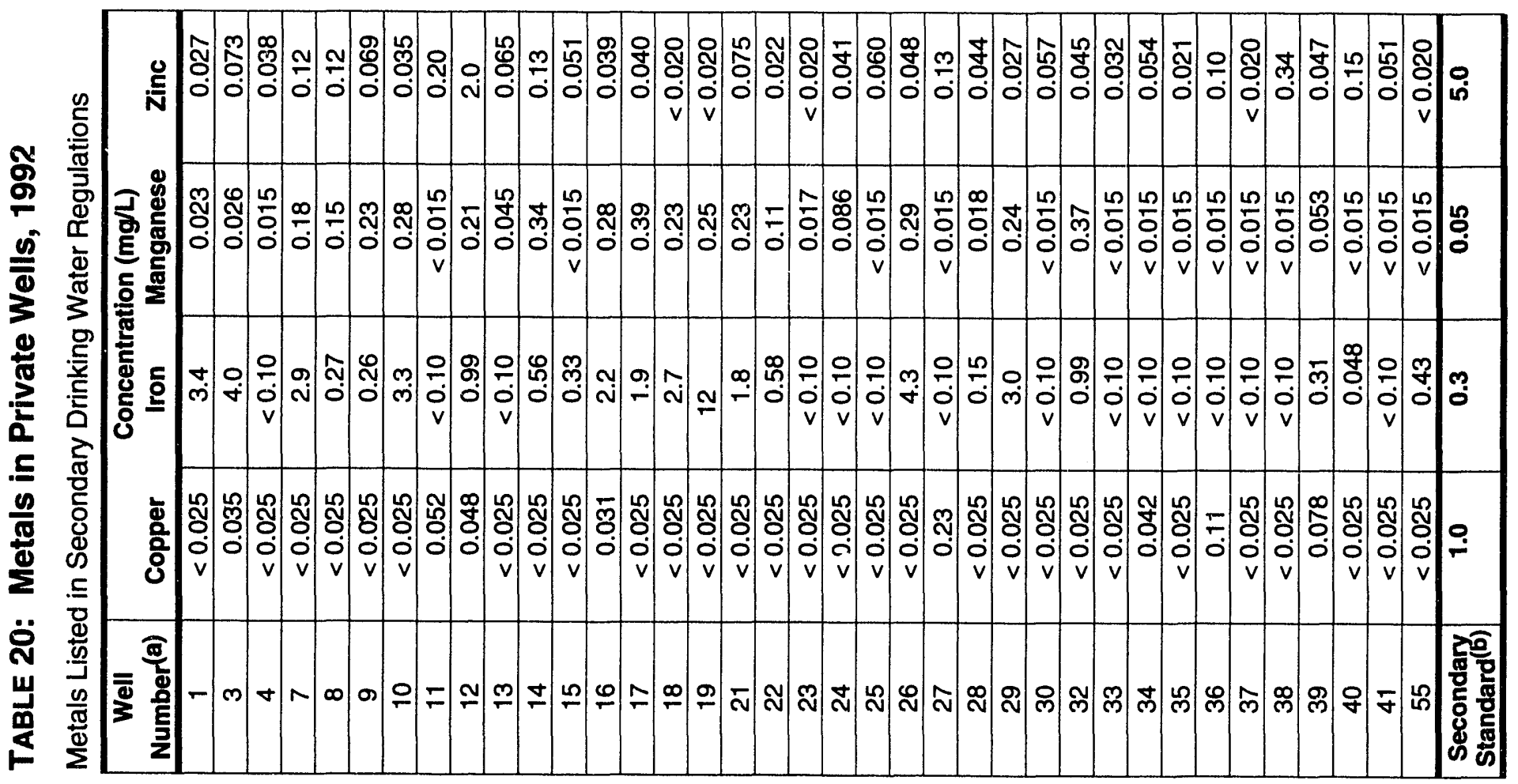




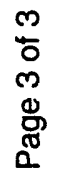
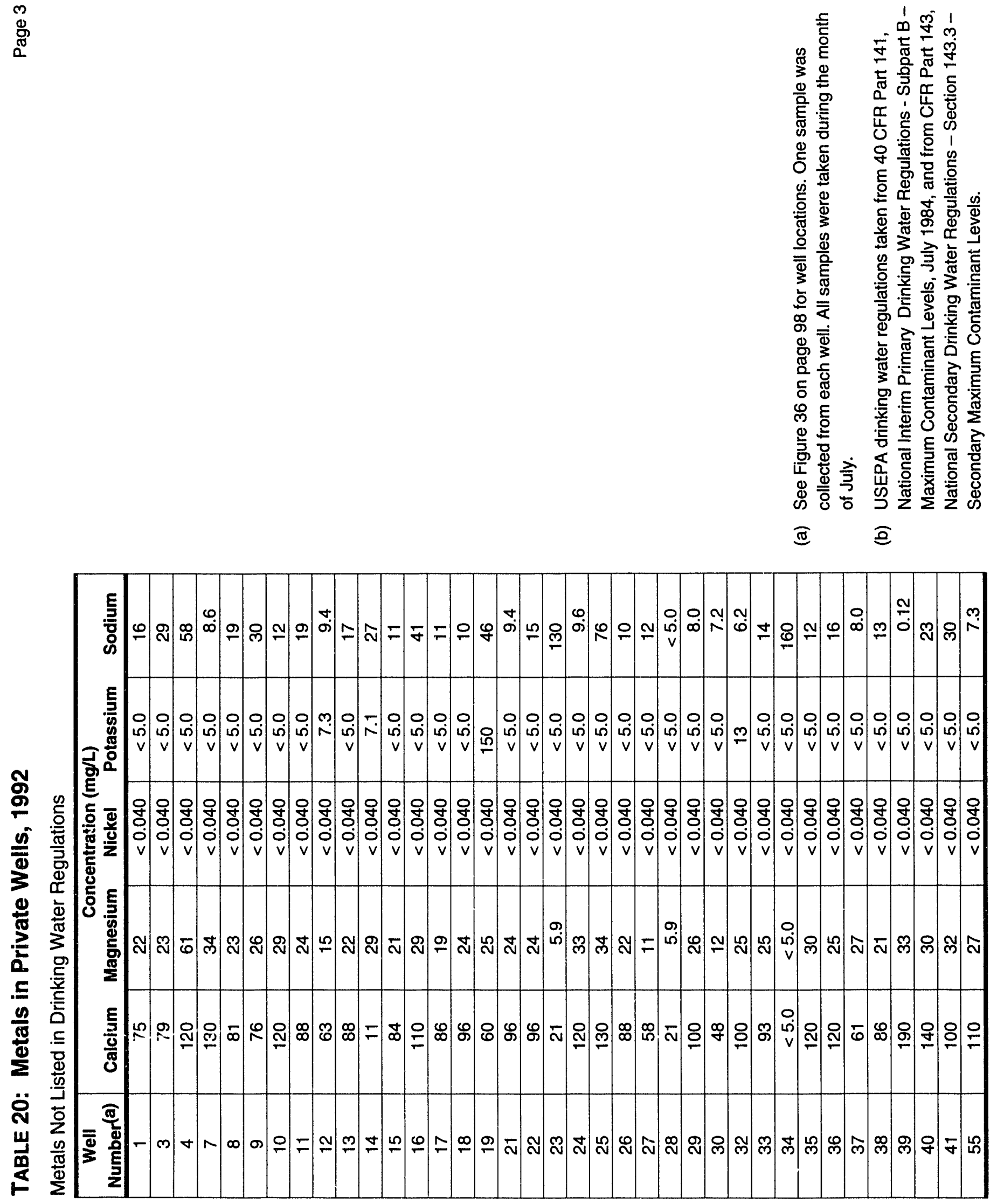
$\frac{\sim}{\dddot{0}}$

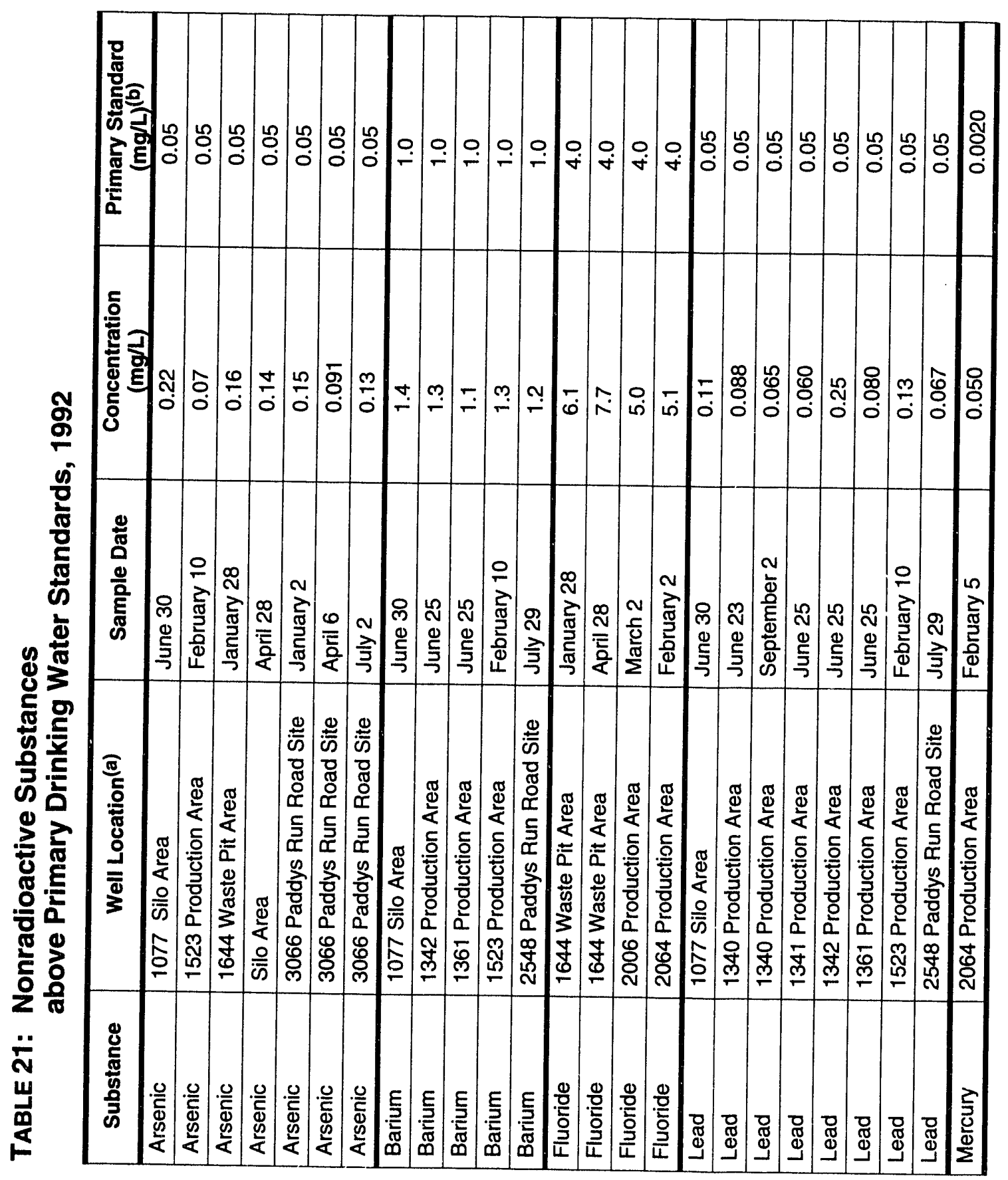




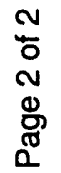

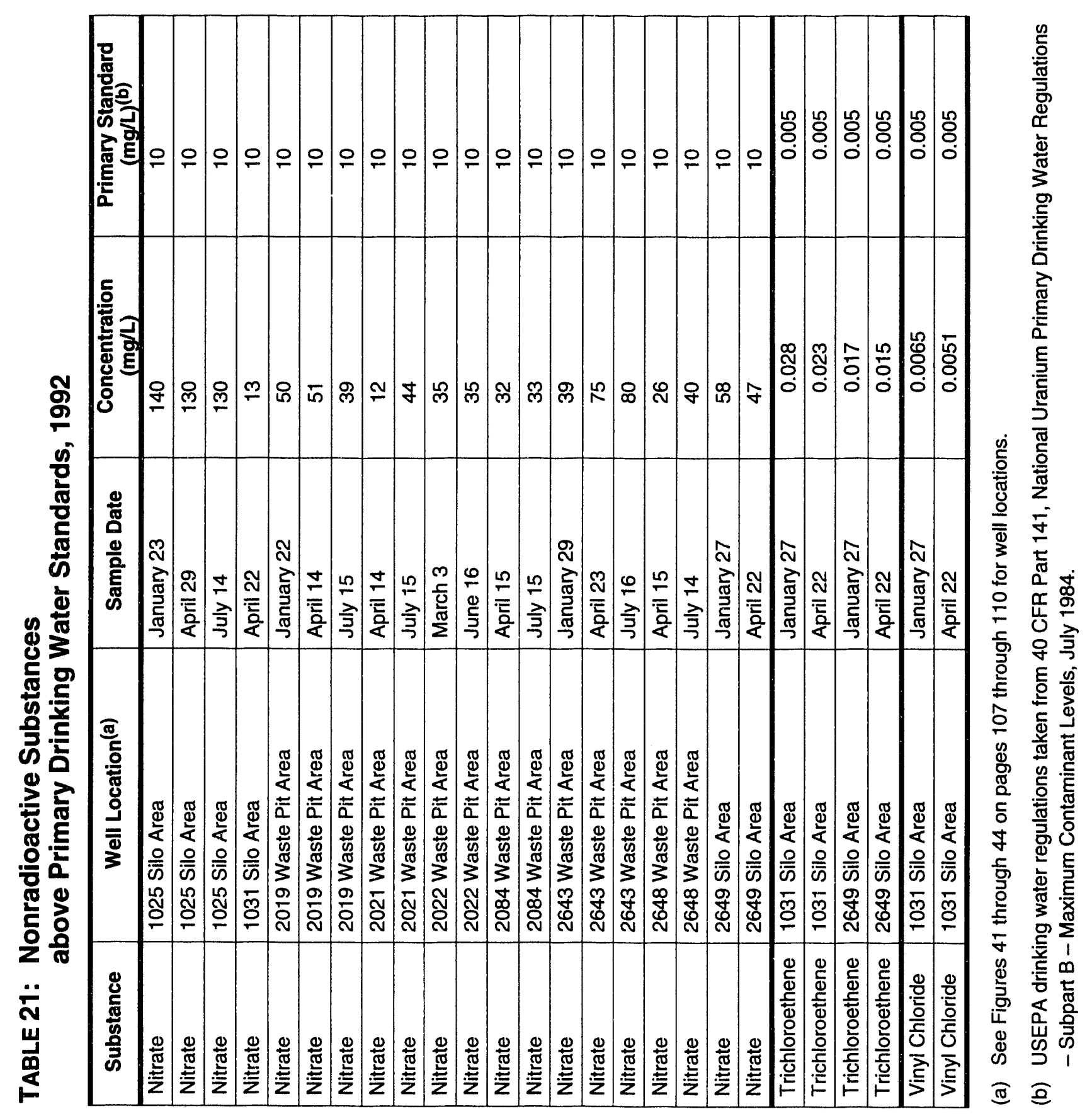




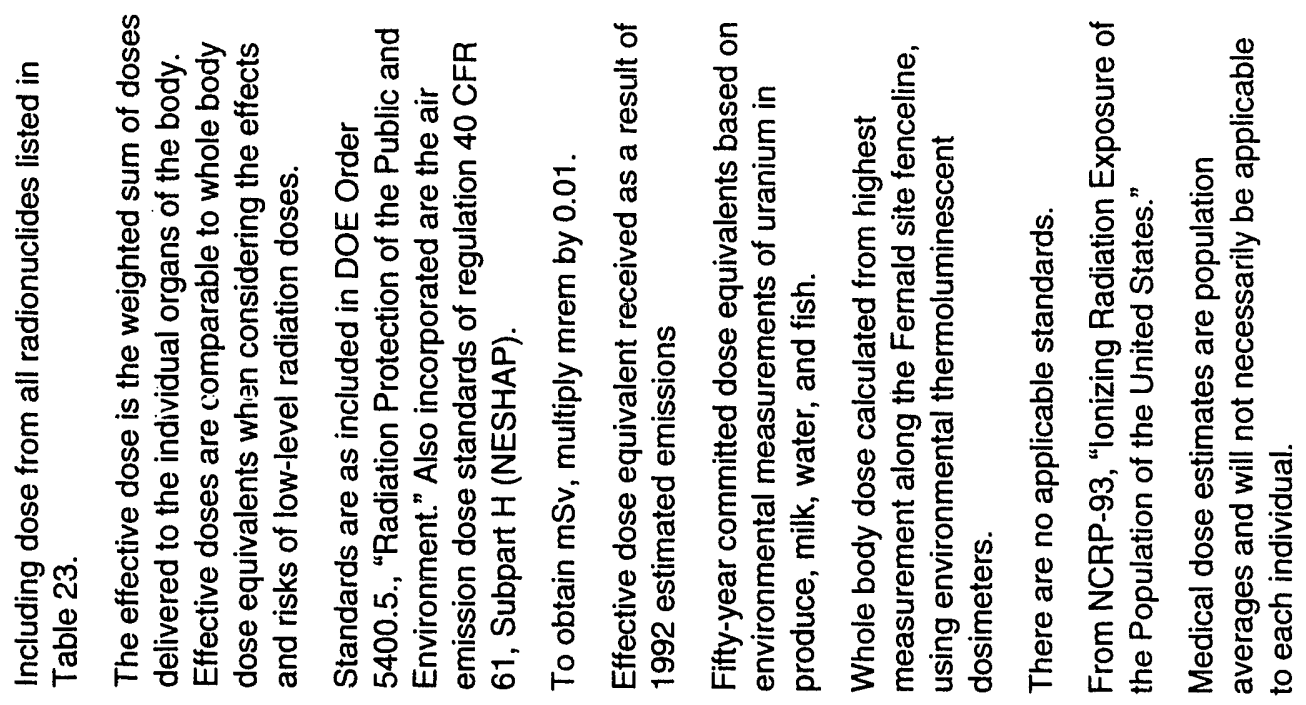

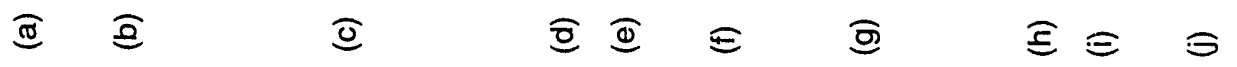

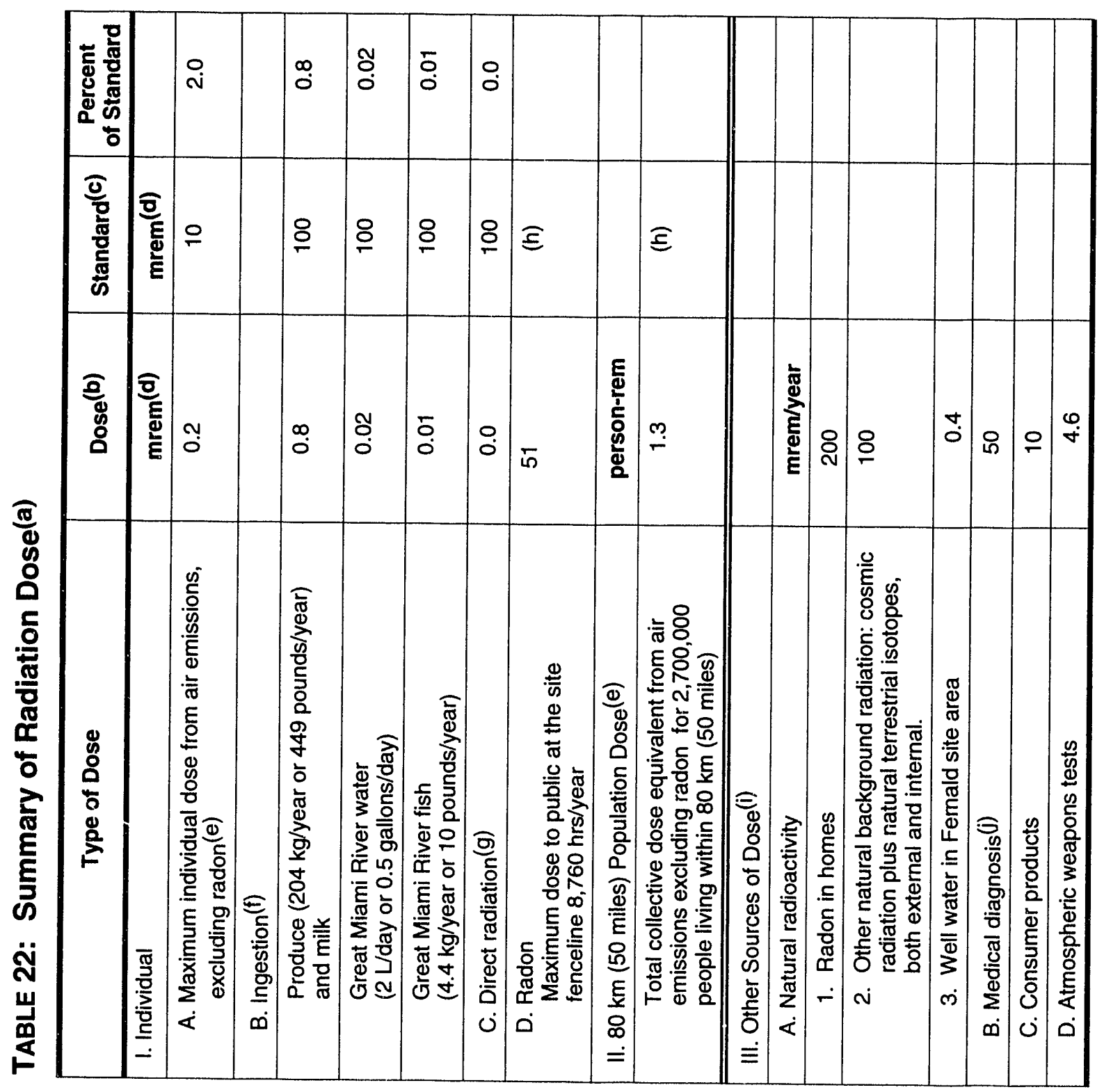




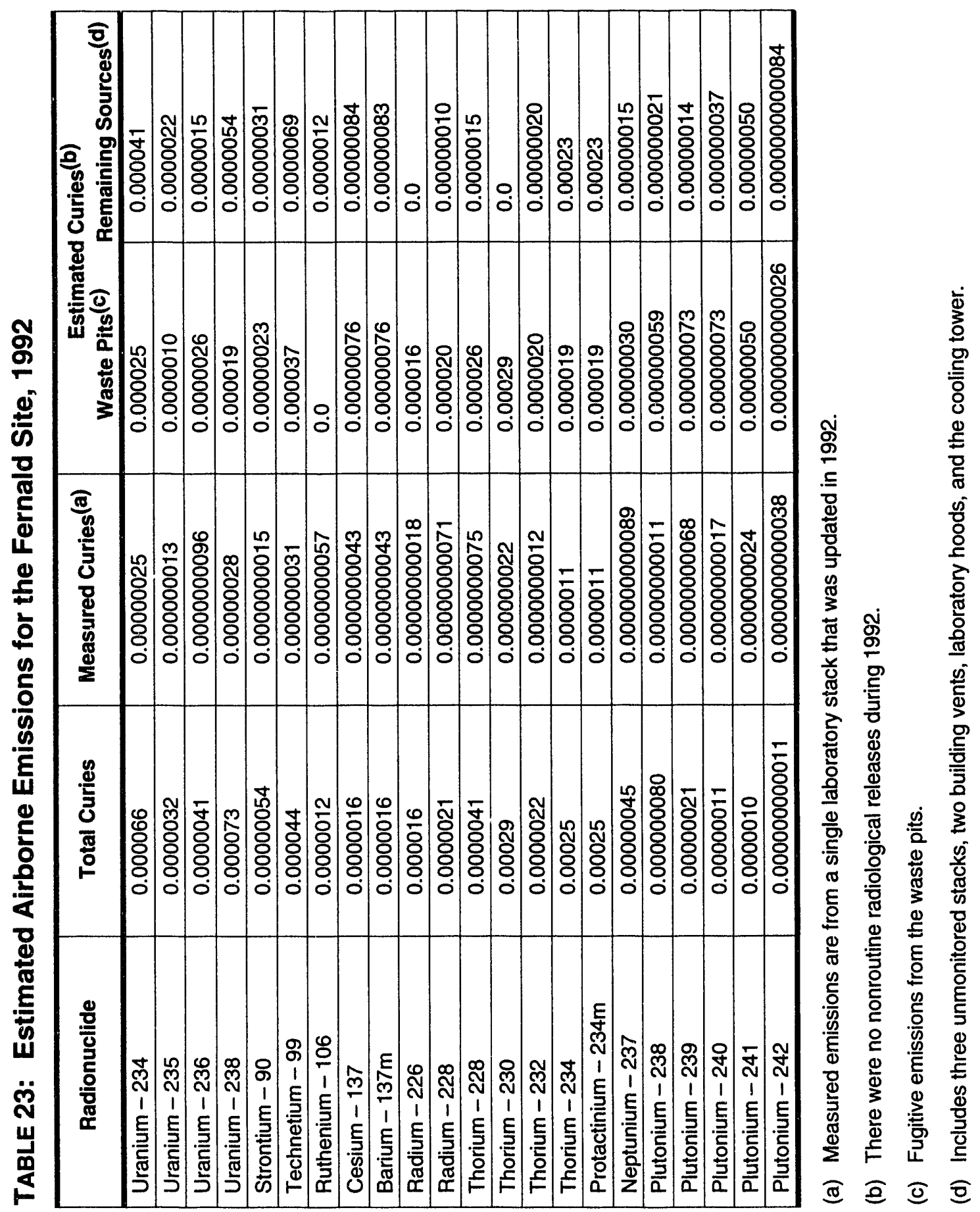



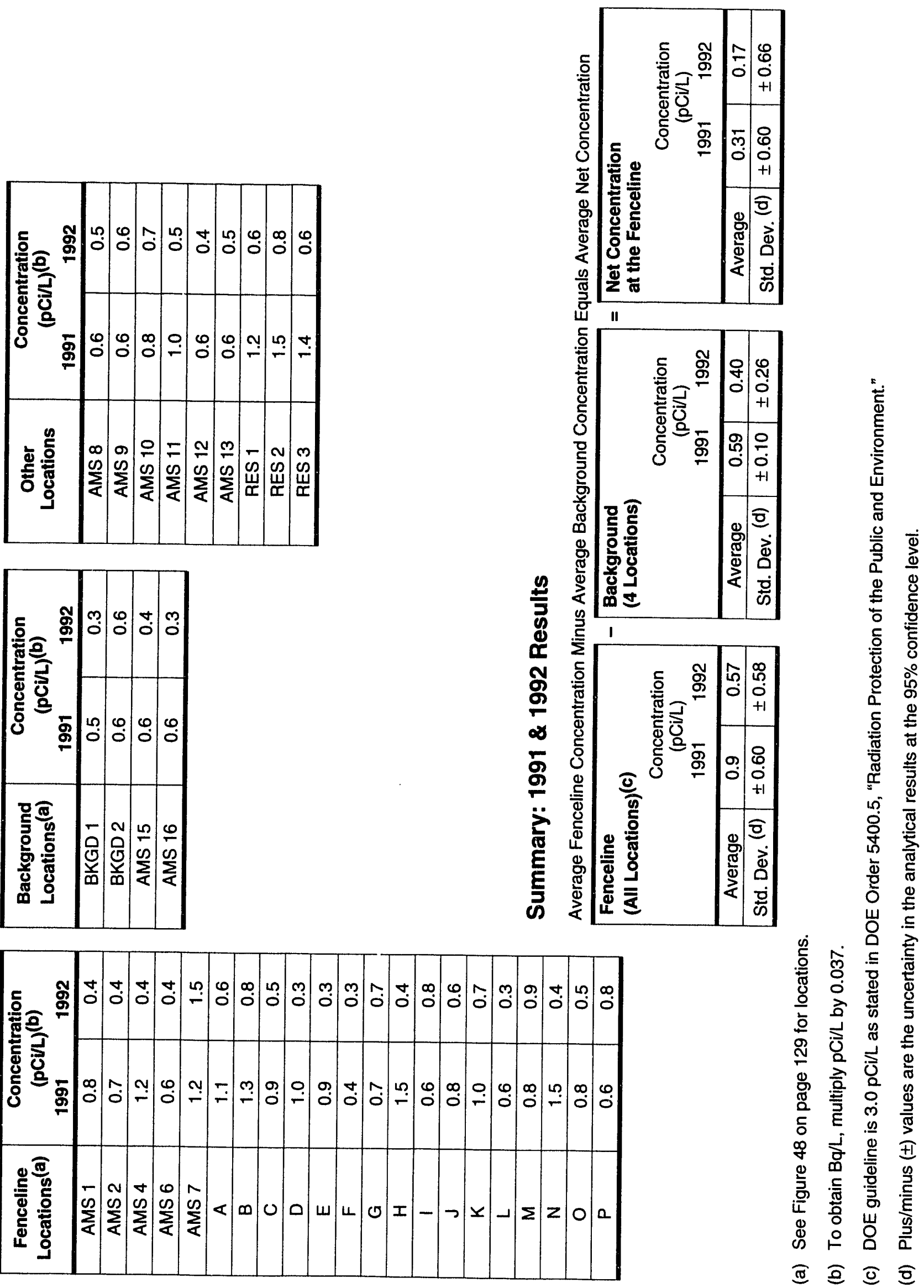


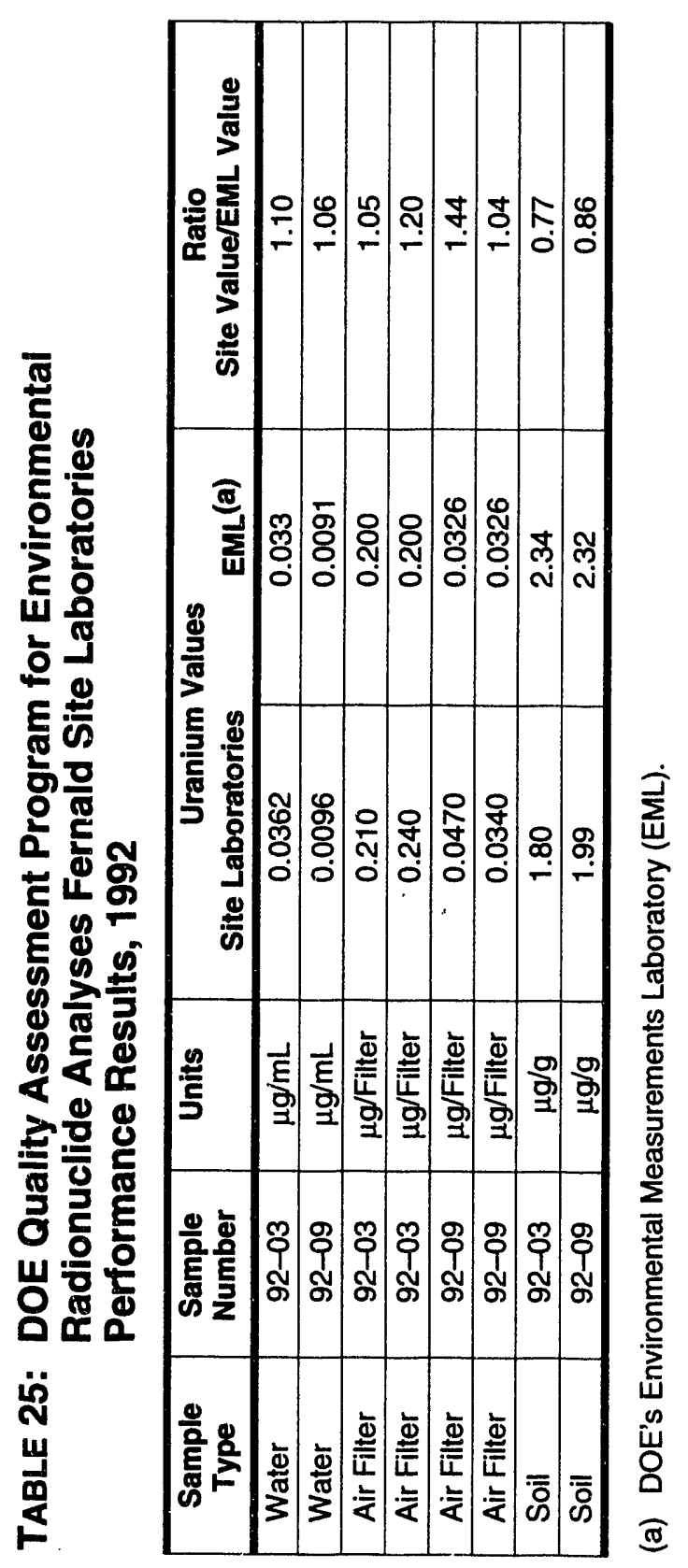




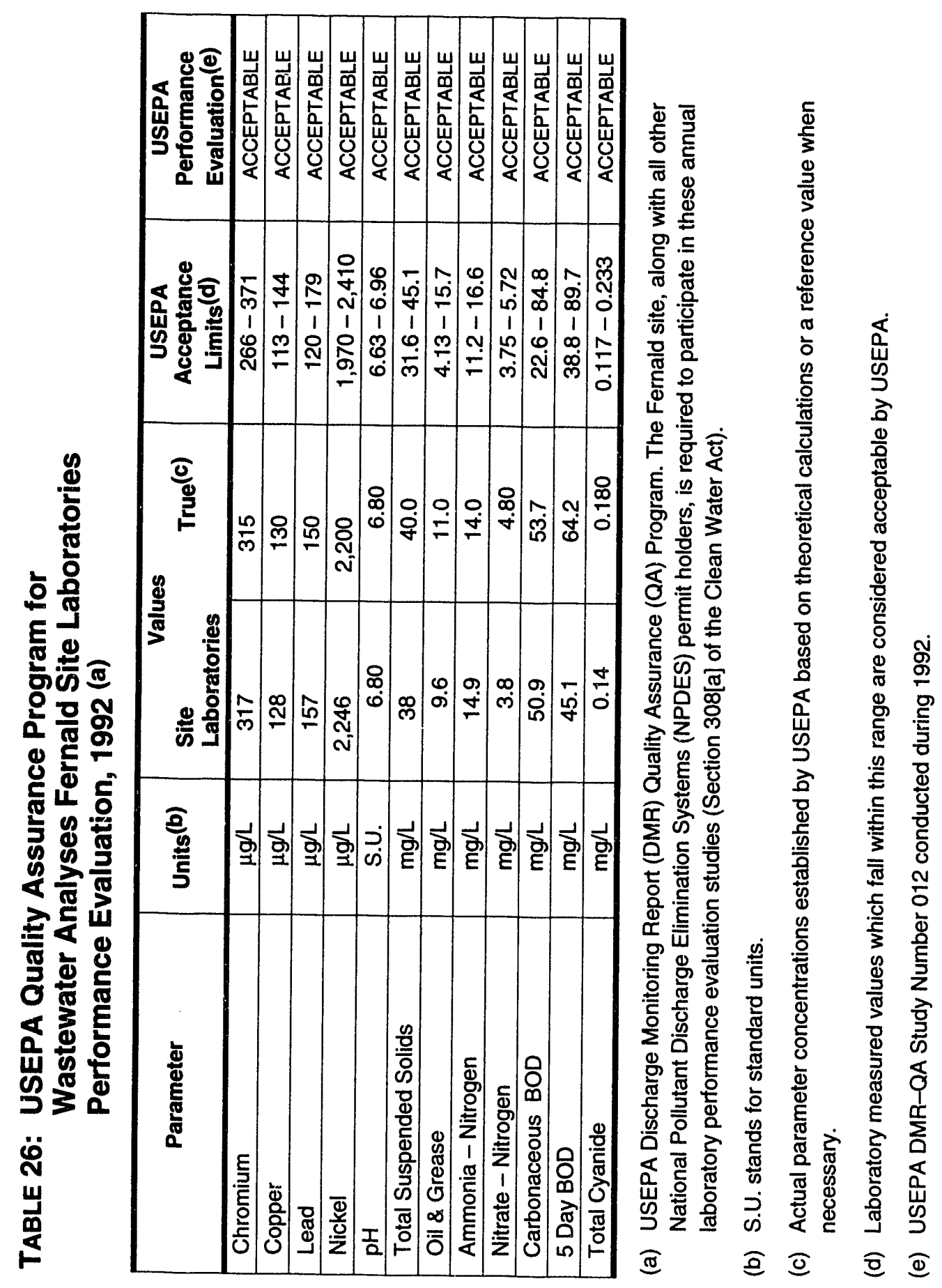


$\frac{5}{0}$

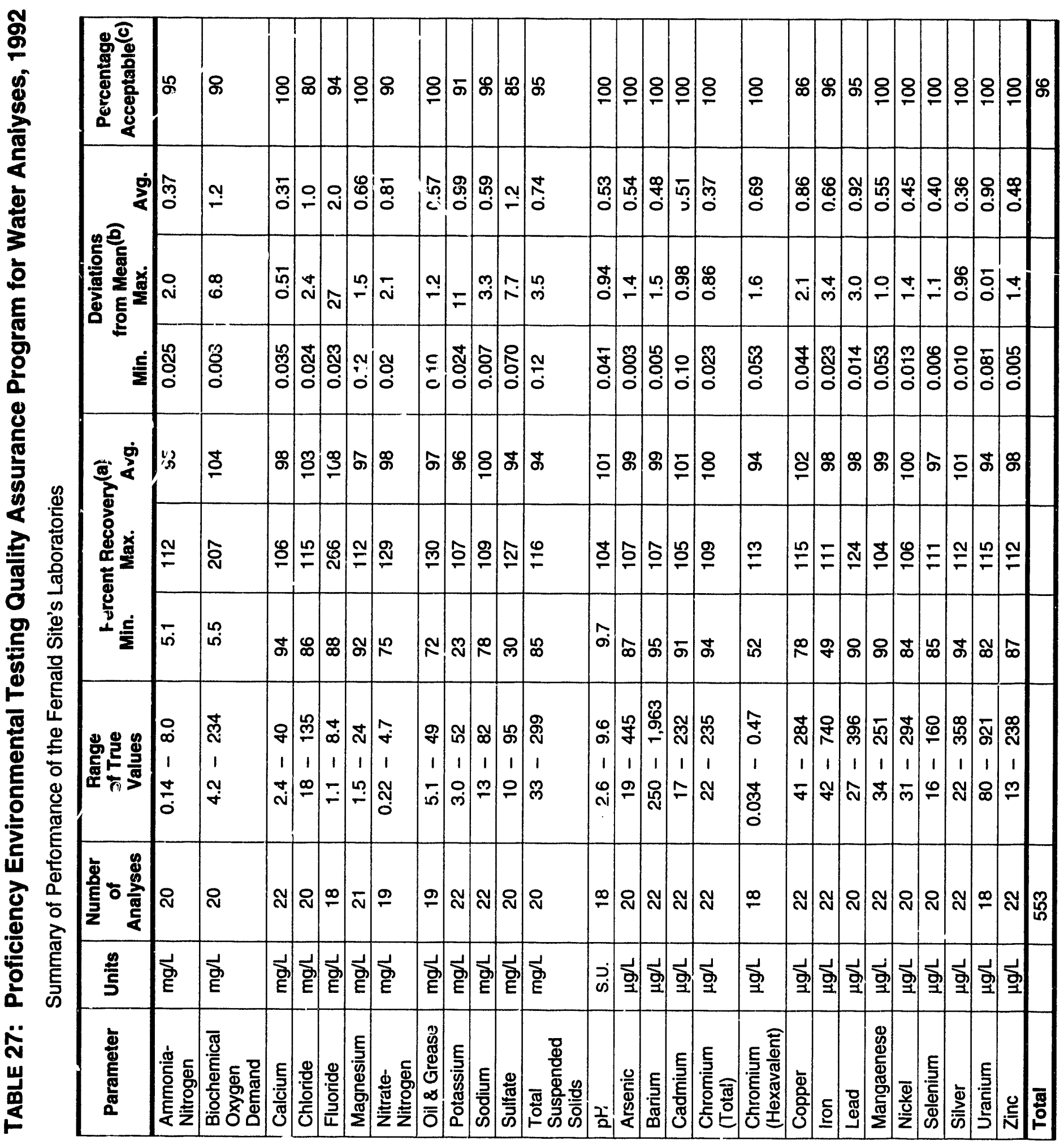




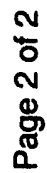

\&

$\frac{8}{8}$

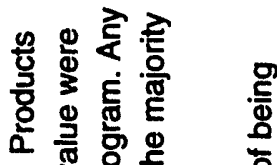

承

츓 을 을

둔 동 층

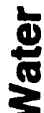

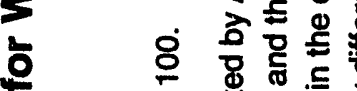

E

政

농웡

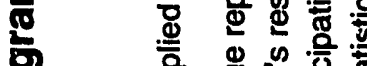

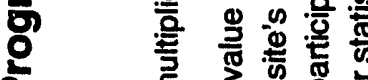

व $\quad$ ह

\&

त

$\frac{5}{8}$

를

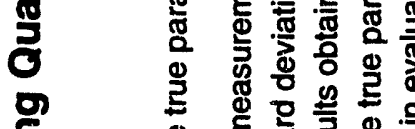

密

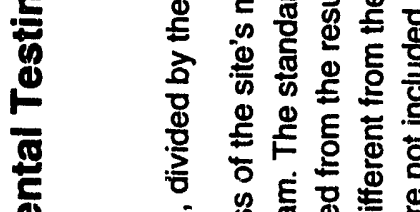

ऽ

ह

은 응 융

단

वे

은

ㅎํㄴ

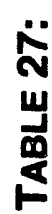

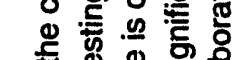

$\neq \Phi .5$

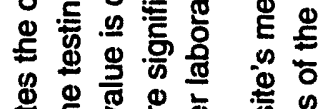

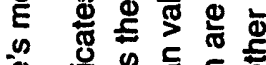

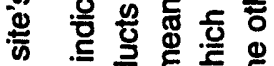

등ㅎํ

.2 荥

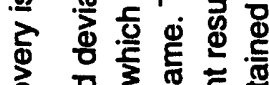

ठํํ융

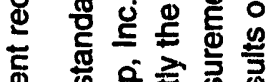

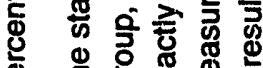

鸟

음

岃

焉

E

$$
\frac{5}{3}
$$


$\frac{m}{\frac{m}{0}}$

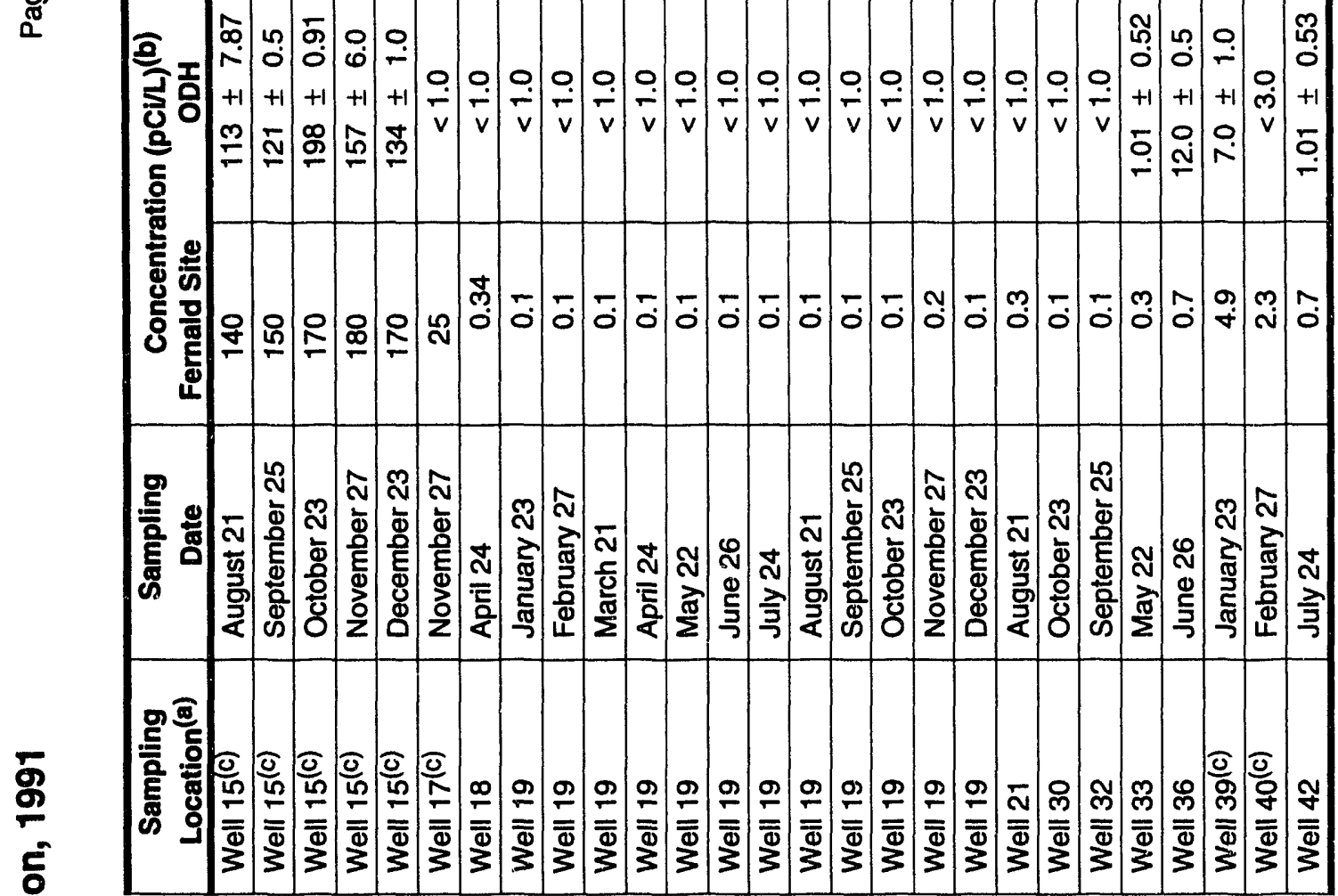

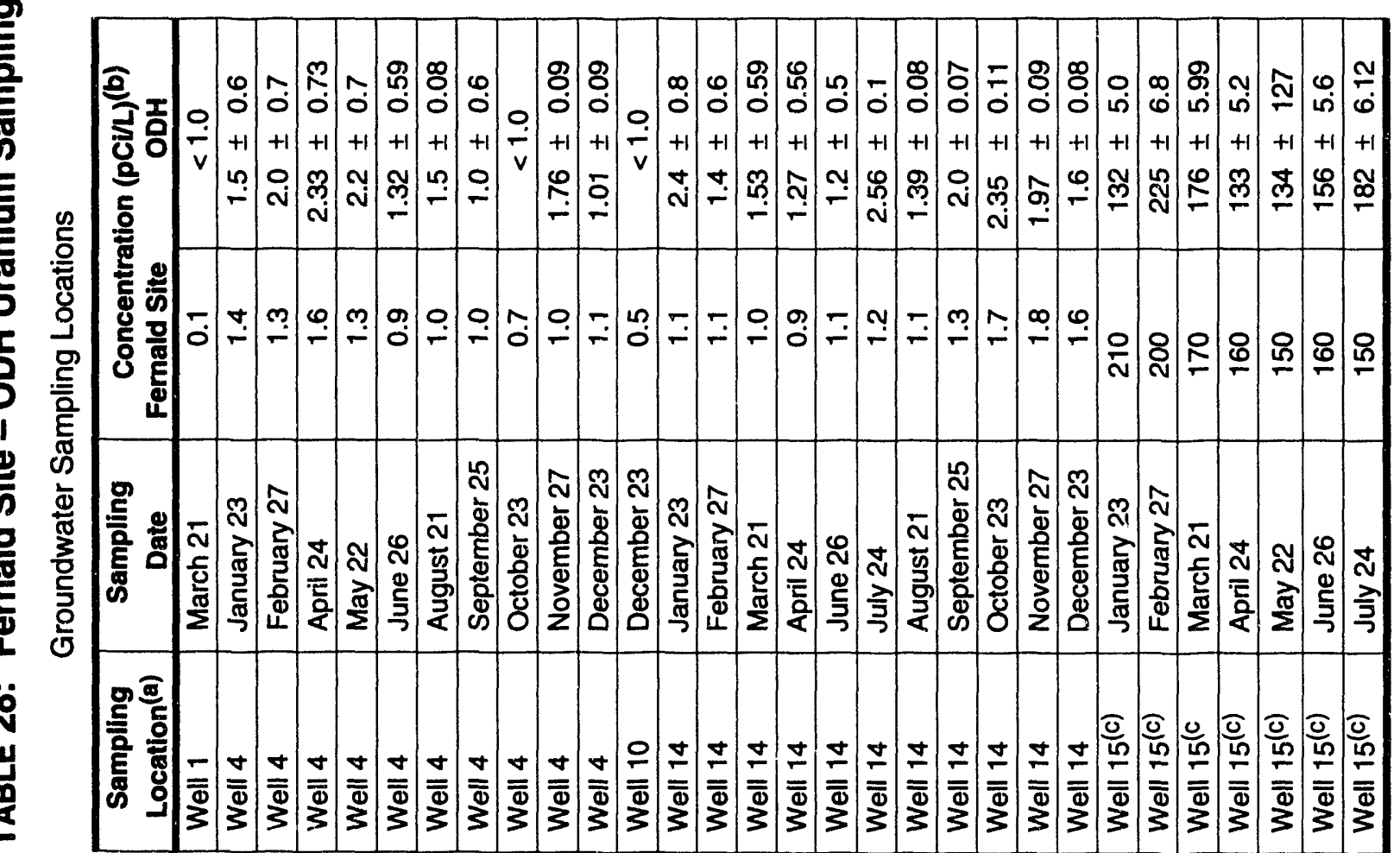




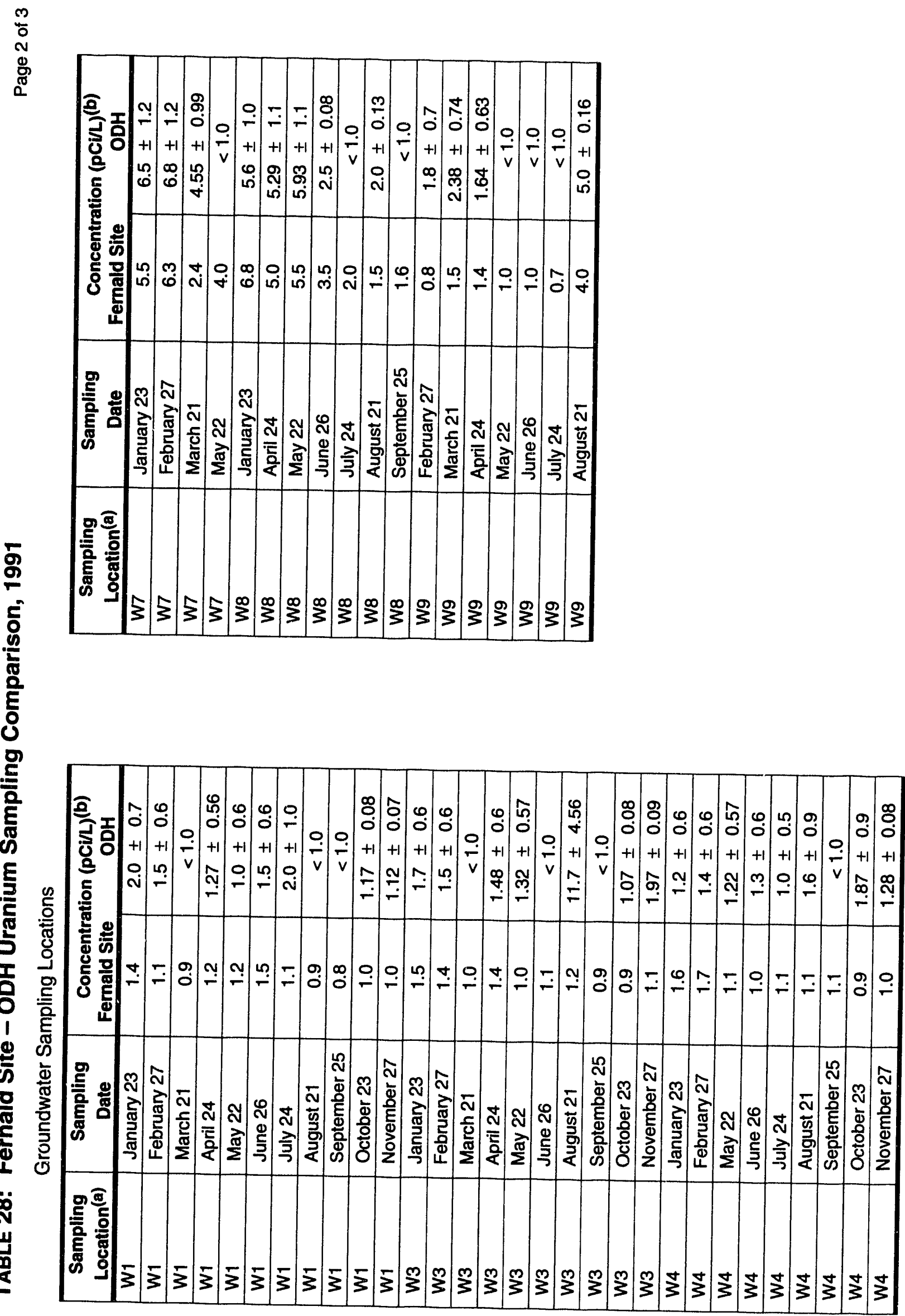


$m$
0
0
0
0
0
0
0

g

동

을

통

톨

1

(1)

\%

$\frac{0}{\pi}$

$\frac{8}{0}$

这

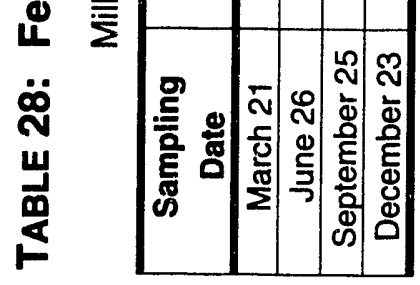

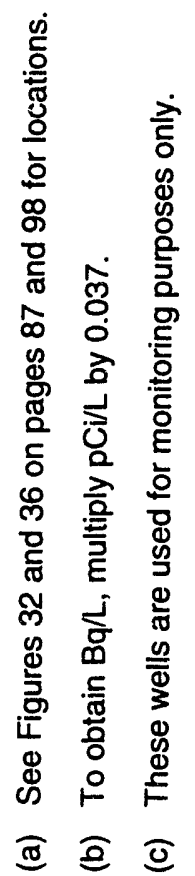




\section{Chemical Release Information for 1992}

Among the information presented in the SER for the Fernald site are estimates on both radiological and nonradiological emissions to the environment. The information in this appendix includes chemical release estimates from the Superfund Amendments and Reauthorization Act of 1986 (SARA) 313 report for 1992 and a summary of emissions from the Boiler Plant during 1992. This summary includes the chemical name, type and quantity of release, major release sources, and the basis of estimate.

To estimate releases, the Fernald site used a method that followed guidelines defined by SARA 313. These estimates do not reflect actual measured emissions. Rather, the Fernald site estimated releases through material balance calculation, monitoring data, or engineering calculations.

In cases where quantitative monitoring data, inventory estimates, or emission factors were not readily available, release estimates were based on best engineering judgments. Information obtained from air permits, rate of operation, quantities used, and known treatment efficiencies were used to estimate quantities released into the environment. Typically, assumptions based on best engineering judgment were required in order to perform the calculations when all variables were not known.

Calculations for Boiler Plant emissions were based on published AP-42 emission factors and coal use and analysis records for the Fernald site during 1992.

The SARA 313 chemicals included in this appendix are a summary of the SARA Title III, Section 313 Report, required by SARA legislation. This legislation requires facilities to report any listed chemical manufactured or processed the previous year in excess of 25,000 pounds, or otherwise used in excess of 10,000 pounds. This report is submitted to USEPA and OEPA each year on July 1 for the previous calendar year and contains chemicals on USEPA's toxic substance list. 


\section{Fernald Site Chemical Release Information for 1992}

Section One: Summary of SARA 313 Report

\begin{tabular}{|l|l|c|l|l|}
\hline \multicolumn{1}{|c|}{$\begin{array}{c}\text { Chemical } \\
\text { Name }\end{array}$} & \multicolumn{1}{|c|}{$\begin{array}{c}\text { Type } \\
\text { of Release }\end{array}$} & $\begin{array}{c}\text { Quantity } \\
\text { Released (lb/kg) }\end{array}$ & \multicolumn{1}{|c|}{$\begin{array}{c}\text { Release } \\
\text { Sources }\end{array}$} & \multicolumn{1}{c|}{$\begin{array}{c}\text { Basis } \\
\text { of Estimate }\end{array}$} \\
\hline Methanol & Air: fugitive & $990 / 450$ & $\begin{array}{l}\text { Chemical } \\
\text { Processing Aid } \\
\text { Chemical } \\
\text { Processing Aid }\end{array}$ & $\begin{array}{l}\text { Published } \\
\text { Emission Factors } \\
\text { Published } \\
\text { Emission Factors }\end{array}$ \\
& Air: point source & & $\begin{array}{l}\text { Chemical } \\
\text { Processing Aid }\end{array}$ & $\begin{array}{l}\text { Best Engineering } \\
\text { Judgment }\end{array}$ \\
\hline Sulfuric Acid & None & Ancillary Use (a) & $\begin{array}{l}\text { Best Engineering } \\
\text { Judgment }\end{array}$ \\
\hline
\end{tabular}

Section Two: Boiler Plant Emissions

\begin{tabular}{|l|l|c|l|l|}
\hline \multicolumn{1}{|c|}{$\begin{array}{c}\text { Chemical } \\
\text { Name }\end{array}$} & \multicolumn{1}{|c|}{$\begin{array}{c}\text { Type } \\
\text { of Release }\end{array}$} & $\begin{array}{c}\text { Quantity } \\
\text { Released (lb/kg) }\end{array}$ & \multicolumn{1}{|c|}{$\begin{array}{c}\text { Major Release } \\
\text { Sources }\end{array}$} & \multicolumn{1}{|c|}{$\begin{array}{c}\text { Basis } \\
\text { of Estimate }\end{array}$} \\
\hline Particulates & $\begin{array}{l}\text { Air: } \\
\text { stack emissions }\end{array}$ & $16,060 / 7,300$ & $\begin{array}{l}\text { Fossil Fuels } \\
\text { Combustion }\end{array}$ & Stack Testing \\
\hline Sulfur Dioxide & $\begin{array}{l}\text { Air: } \\
\text { stack emissions }\end{array}$ & $162,800 / 74,000$ & $\begin{array}{l}\text { Fossil Fuels } \\
\text { Combustion }\end{array}$ & $\begin{array}{l}\text { AP-42 Emission } \\
\text { Factors }\end{array}$ \\
\hline Nitrogen Oxide & $\begin{array}{l}\text { Air: } \\
\text { stack emissions }\end{array}$ & $149,600 / 68,000$ & $\begin{array}{l}\text { Fossil Fuels } \\
\text { Combustion }\end{array}$ & $\begin{array}{l}\text { AP-42 Emission } \\
\text { Factors }\end{array}$ \\
\hline Carbon Monoxide & $\begin{array}{l}\text { Air: } \\
\text { stack emissions }\end{array}$ & $52,800 / 24,000$ & $\begin{array}{l}\text { Fossil Fuels } \\
\text { Combustion }\end{array}$ & $\begin{array}{l}\text { AP-42 Emission } \\
\text { Factors }\end{array}$ \\
\hline $\begin{array}{l}\text { Non-methane } \\
\text { Volatile } \\
\text { Organic } \\
\text { Compounds }\end{array}$ & $\begin{array}{l}\text { Air: } \\
\text { stack emissions }\end{array}$ & $1,498 / 679$ & $\begin{array}{l}\text { Fossil Fuels } \\
\text { Combustion }\end{array}$ & $\begin{array}{l}\text { AP-42 Emission } \\
\text { Factors }\end{array}$ \\
\hline
\end{tabular}

(a) Chemical processing aid during $\mathrm{pH}$ adjustment and regeneration of ion exchangers.

(b) Calculations were based on AP-42 emission factors and 1992 Fernald site coal use and analysis records.

\section{Fernald Site Source Reduction Information for 1992}

\section{Section One: Summary of SARA 313 Report}

\begin{tabular}{|l|l|c|c|c|}
\hline $\begin{array}{c}\text { Chemical } \\
\text { Name }\end{array}$ & \multicolumn{1}{|c|}{$\begin{array}{c}\text { Type } \\
\text { of Treatment }\end{array}$} & $\begin{array}{c}\text { Quantity } \\
(\mathrm{lb} / \mathrm{kg})\end{array}$ & $\begin{array}{c}\text { Treatment } \\
\text { Method }\end{array}$ & $\begin{array}{c}\text { Basis } \\
\text { of Estimate }\end{array}$ \\
\hline Methanol & Treated onsite & $1,200 / 546$ & Biological-Aerobic & $\begin{array}{l}\text { Best Engineering } \\
\text { Judgment }\end{array}$ \\
\hline
\end{tabular}




\section{References}

1 General Environmental Protection Program, U.S. Department of Energy Order 5400.1, November 9, 1988.

2 Feed Materials Production Center, Fernald, Ohio, Remedial Investigation Report for Operable Unit 4 Task 6 Report, Final Draft, U.S. Department of Energy, Oak Ridge Operations Office, October 1990.

3 GeoTrans, Inc., Preliminary Characterization of the Groundwater Flow System Near the Feed Materials Production Center, Great Miami River Valley-Fill Aquifer, Fernald, Ohio, September 1985.

4 Speiker, A. M., Groundwater Hydrology and the Geology of the Lower Great Miami River Valley, Ohio, USGS Professional Paper 605-A, 1968.

5 Dames and Moore, Groundwater Study Task C Report, June 1985.

6 FMPC Environmental Monitoring Section, 1990 Groundwater Monitoring Annual Report for the Fernald Site, Draft, November 1991.

7 Rozelle, James L., Letter to J. M. Byrne, March 11, 1993.

8 Radiation Protection for the Public and the Environment, U.S. Department of Energy Order 5400.5, February 8, 1990.

9 International Commission on Radiological Protection, Annals of the ICRP, Recommendations of the International Commission on Radiological Protection, ICRP Publication Nos. 26/30, Parts 1, 2, 3, Pergamon Press, Oxford, NY, 1977, 1979, 1980 , and 1981.

10 National Emission Standards for Hazardous Air Pollutants - Subpart H - National Emission Standards for Emissions of Radionuclides other than Radon from DOE Facilities, Code of Federal Regulations, Title 40, Parts 61.93 and 61.94, Vol. 50, No. 25, February 1985.

11 National Interim Primary Drinking Water Regulations - Subpart B - Maximum Contaminant Levels, Code of Federal Regulations, Title 40, Part 141, July 1, 1984.

12 National Council on Radiation Protection and Measurements, Ionizing Radiation Exposure of the Population of the United States, NCRP-93, 1987.

13 Upton, Arthur C., The Biological Effects of Low-Level Ionizing Radiation, Scientific American, pp. 41-49, February 1982.

14 The American Nuclear Society and the International Atomic Energy Agency, Radiation - A Fact of Life, 1979.

15 Eisenbud, Merril, Environmental Radioactivity, 2nd ed., New York, Academic Press, 1973. 
16 Murray, Raymond L., Understanding Radioactive Waste, 2nd ed., Columbus, Ohio, Battelle Press, 1983.

17 Kingman, Sharon, A Lot of Fuss About a Few Millisieverts, New Scientist, May 15, 1986.

18 Marx, Jean L., Lower Radiation Effect Found, Science, September 9, 1988.

19 National Research Council, Health Effects of Exposure to Low Levels of Ionizing Radiation, BEIR V, National Academy Press, 1990.

20 U.S. Department of Energy, Office of Environmental Guidance, "Hazardous" Terminology, January 1991.

21 Myrich, T. E., B. A. Berven, and F. F. Haywood, Determination of Concentrations of Selected Radionuclides in Surface Soil in the U.S., Health Physics, 453, 1983.

22 U.S. Environmental Protection Agency, Method for Estimating Fugitive Particulate Emissions from Hazardous Waste Sites, EPA/600/2-87/066, PB87 - 232203, Cincinnati, Ohio, August 1987.

23 Radiological Effluent Monitoring and Environmental Surveillance, Code of Federal Regulations, Title 10, Part 834, Draft, January 10, 1991.

24 U.S. Department of Energy, CERCLA/RCRA Background Soil Study, Fernald Environmental Management Project, Final, March 1993.

25 Reinhart, R. H., Statistical Evaluation of Produce Samples, M:ESHA:ESA:93-070, April 6, 1993.

26 Ohio Environmental Protection Agency, Measurements and Procedures, Laws and Regulations, Regulation No. 3745-1804, November 1984.

27 Reinhart, R. H., Statistical Evaluation of Surface Water, M:ESHA:ESA:93-096, April 6, 1993.

28 Miller, Michael C., Electrofishing Survey of the Great Miami River, August 20 - 23, Draft, University of Cincinnati Department of Biological Sciences, November 1992.

29 Reinhart, R. H., Great Miami River Fish Data for 1992, M:ESHA:ESA:93-061, April 6, 1993.

30 Hem, John, D., Study and Interpretation of the Chemical Characteristics of Natural Water, Geological Survey Water Supply Paper 1473, 1982.

31 Varchol, B. D., Statistical Evaluation of Homeowner Wells, WMCO:R:(EM): 90-0296, June 7, 1990.

32 Secondary Maximum Contaminant Levels, Code of Federal Regulations, Title 40, Part 143, July 1, 1988.

33 Controls for Environmental Pollution, Inc., Drinking Water Handbook, Santa Fe, New Mexico, 1988. 
34 National Secondary Drinking Water Regulations, Code of Federal Regulations, Title 40, Part 143, July 1991.

35 Fernald Environmental Restoration Management Corporation, 1992 RCRA Annual Report, Volume 1, 1993.

36 Miller, Charles W., ed., Models and Parameters for Environmental Radiological Assessments, Report DOE/TIC - 11468, Oak Ridge National Laboratory, 1984.

37 National Council on Radiation Protection and Measurements, Evaluation of Occupational and Environmental Exposures to Radon and Radon Daughters in the United States, NCRP - 78, 1984.

38 Napenas, D. D., A Study on Radon Concentration Levels in Ohio, Kentucky, and Indiana Areas, University of Cincinnati College of Engineering, December 1989. 


\section{Glossary}

Activity the rate of disintegration, expressed as disintegrations per second (Becquerels) or in units of Curies (one Curie $=3.7 \times 10^{10}$ Becquerels).

ALARA a phrase and acronym (As Low As Reasonably Achievable) used to describe an approach to radiation exposure and emissions control or management whereby the exposures and resulting doses to the public are maintained as far below the specified limits as economic, technical, and practical considerations will permit.

Aliquot the fraction of a field sample taken for complete processing through an analytical procedure (a "laboratory sample" of a field sample).

Alpha Particle

Anion

Aquifer

Background Radiation

Biological Indicator

Blank

Calibration

Confidence Coefficient type of particulate radiation (identical to the nucleus of the helium atom) consisting of two protons and two neutrons.

the negatively charged atom in an ionic compound.

a body of rock that is sufficiently permeable to conduct groundwater and to yield economically significant quantities of water to wells and springs.

the radiation in the natural environment, including cosmic rays and radiation from the naturally radioactive elements, both outside and insicie the bodies of humans and animals.

Backlog onsite waste awaiting permitted treatment, storage, or disposal options.

Beta Particle type of particulate radiation emitted from the nucleus of an atom that has a mass and charge equal in magnitude to that of the electron.

machined ingots. During production times at the site, these billets were shipped to other DOE sites for use.

organisms that reveal the presence of pollution in an ecosystem. For instance, algal blooms indicate organically or nutrient enriched waters.

a sample of the carrying agent (gas, liquid, or solid) normally used to selectively measure a material of interest that is subjected to the usual analytical procedures process to establish a baseline or background value. This value is then used to adjust or correct the routine analytical results.

the adjustment of the system and the determination of system accuracy using known sources and instrument measurements. Adjustment of flow, temperature, humidity, or pressure gauges and the determination of system accuracy should be conducted using standard operating procedures and sources that are traceable to the National Institute of Standards and Technology.

the chance or probability, usually expressed as a percentage, that a confidence interval includes some defined parameter of a population. The confidence coefficients usually associated with confidence intervals are $90 \%, 95 \%$, and $99 \%$. For a given sample size, the width of the confidence interval increases as the confidence coefficient increases. 
Confidence Interval

Conservative Estimate

Contamination

Critical Organ

Critical Pathway

Curie (Ci) and

Becquerel (Bq)

Daughter

Decay

Derby

Derived

Concentration Guideline

Dose

Drum Equivalent

Effluent Monitoring

Enrichment

Environmental

Detection Limit

Exposure Pathway a value interval that has a designated probability (the confidence coefficient) of including some defined parameter of the population.

used frequently in environmental monitoring and dose calculation, it is based on assumptions about an exposure situation that should result in the highest estimate of a dose.

any substance or material that is somewhere it is not supposed to be.

the human organ or tissue receiving the largest fraction of a specified dose limit.

the specific route of transfer of radionuclides from one environmental component to another that results in the greatest fraction of an applicable dose limit to a population group or an individual's whole body, organ, or tissue.

are units of radioactivity that measure the rate of spontaneous, energy-emitting transformations in the nuclei of atoms. One Curie equals 37 billion transformations per second. One Becquerel equals one transformation per second. One Curie ( 37 billion $\mathrm{Bq}$ ) of natural uranium is equivalent to a mass of about 1,500 kilograms (3,300 pounds).

a nucleus that results from radioactive decay; also, progeny.

the disintegration process of an atomic nucleus.

the main product of the former site processing of uranium metal.

the concentration of a radionuclide in air or water that, under conditions of continuous exposure for one year by one exposure mode (for example, drinking water or breathing the air) that would result in either an effective dose equivalent of $0.1 \mathrm{rem}(1 \mathrm{mSv})$ or a dose equivalent of $5 \mathrm{rem}(50 \mathrm{mSv})$ to any tissue, including skin and the lens of the eye.

quantity of radiation absorbed in tissue.

the number of 55-gallon drums that it would take to contain a given volume of waste.

the collection and analysis of samples or measurements of liquid, gaseous, or airborne effluents for the purpose of characterizing and quantifying contaminants and process stream characteristics, assessing radiation exposures to members of the public, and demonstrating compliance with applicable standards.

a process to increase the percentage of a desired isotope such as uranium-235.

the lowest concentration at which a radionuclide in an environmental medium can be unambiguously distinguished for a given confidence level using a particular combination of sampling and measurement procedures, sample volume, analytical detection limit, and processing procedure.

a route by which materials could travel between the point of release and the point of delivery of a radiation or chemical dose to a person. 
Fission the splitting of a heavy nucleus into two approximately equal parts, accompanied by the release of large amounts of energy and generally one or more neutrons.

Fugitive Dust dust that did not flow through a production stack. This includes materials such as dust from the waste storage areas, administration areas, and dust that originated from construction activities.

Gamma Ray type of electromagnetic radiation of discreet energy emitted during radioactive decay of many radioactive elements.

Glacial Till the mix of clay, silt, sand, gravel, and boulders deposited by the glaciers.

Half Life the length of time for half the atoms of a given radioactive substance to decay.

Hydrology the study of the properties, distribution, and circulation of water through the local environment.

ICRP International Commission on Radiological Protection is an organization founded in 1928 and whose function is to recommend international standards for radiation protection.

Ingot remelted derbies and uranium scrap-metal from the former site production process. They varied in weight, size, and shape according to how they were used at this and other DOE sites.

Ionization removal of electrons from an atom, such as by means of interaction with radiation.

Isotope atoms with the same atomic number but different mass number. Isotopes usually have the same chemical properties, but could have very different radiological properties (such as half-life and type of radiation emitted).

Less than Detectable

Lithology

Lower Limit of Detection

Minimum Detection Level

Mixed Wastes

Monitor refers to a measurement or calculated concentration that is not statistically different from the associated background or control value at a selected confidence level.

the study, classification, and mapping of rocks and rock formations.

the smallest amount of a contaminant that can be distinguished in a sample by a given measurement procedure at a given confidence level.

the minimum amount of the constituent or species of interest that can be observed by an analytical instrument and distinguished from background and instrument noise with a specified degree of probability.

hazardous waste that has been contaminated with low-level radioactive materials.

1) to measure certain constituents or parameters in an effluent stream continuously or at a frequency that permits a representative estimate of the amount over a specified interval of time;

2) the instrument or device used in monitoring. 
NCRP National Council on Radiation Protection and Measurements chartered by Congress in 1914 and charged with developing radiation protection standards.

Nuclide a general term applicable to all atomic forms of the elements, including isotopes.

Null Allele an inactive group of genes.

Occurrence any sudden release or sustained deviation from a regulated or planned performance of an operation that has environmental protection and compliance significance.

Onsite refers to the area within the boundaries of a facility or site that is or can be controlled with respect to access by the general public.

Opacity how much light is blocked by particulates present in stack emissions.

Operable Unit a discrete action that comprises an incremental step toward comprehensively addressing site problems. Operable units may address geographical portions of a site, specific site problems, or initial phases of an action performed over time, or any actions that are concurrent but located in different parts of the site.

Overburden the soil, rock, and other naturally occurring material overlying the bedrock.

Overpacking the act of placing a deteriorating drum inside a new, larger drum to prevent further deterioration or the possible release of contaminants during storage.

Parent Material a radionuclide that produces a specific "daughter" product either directly or as a later result of radioactive decay or disintegration.

Person-rem a collective dose to a population group. For example, a dose of one rem to ten people results in a collective dose of ten person-rem.

Plate Out a thermal, electrical, chemical, or mechanical action that results in a loss of material by deposition on surfaces.

Point Source the single defined point (origin) of a release such as a stack, vent, pipe, or other discernable conveyance.

Positive Interference

Potable Water

Radioactive Emissions

Radioactive Material

Radioisotope

Radionuclide

Random Samples during sampling analysis, this produces a result that indicates the presence of a radionuclide when, in fact, there is very little or no presence of this radionuclide in the sample.

water that is suitable for consumptive purposes.

releases of radioactive materials to the environment.

refers to any material or combination of materials that spontaneously emits ionizing radiation.

a radioactive isotope.

refers to a radioactive nuclide. There are several hundred known radionuclides, both artificially produced and naturally occurring; radionuclides are characterized by the number of neutrons and protons in an atom's nucleus and their characteristic decay processes.

samples that are obtained in such a manner that all items or members of the lot, or population, have an equal chance of being selected in the sample. 
Remedial Action

Rem? ial Action

Representative Sar ple

Roentgen Equivalent Man (rem) and Sievert (Sv)

Roentgen (R) and Coulombs per kilogram (C/kg)

Sample

Sampling

Scintillation Cell

Sensitivity

Site Char acterization

Spiked Sample

Terrace Remnants

Thermoluminescent Dosimeter

Tolerance Limits

Transuranic

Wetland an action that is consistent with the final remedy following a formal examination of the nature and extent of the release, or threat of release, assessment of the risk, and selections of the final remedy based on an evaluation of possible alternatives (RI/FS process).

any necessary action to abate an immediate threat to health and the environment, including actions necessary to monitor, assess, or evaluate the threat.

a sample taken to depict the characteristics of a lot or population as accurately and precisely as possible. A representative sample may be a "random sample" or a "stratified sample" depending upon the objective of the sampling and the characteristic $r$ of the conceptual population.

units of dose which account for the relative biological damage due to the type of radiation involved. One rem equals $0.01 \mathrm{~Sv}$.

units of exposure to radioactivity. One R equals $2.6 \times 10^{-4} \mathrm{C} / \mathrm{kg}$, and is a measure of the ionization in air due to a source of radioactivity.

1) a subset or group of objects selected from a larger set, called the population;

2) an extracted portion of a subset of an effluent stream or environmental medium.

the extraction of a prescribed portion of an effluent stream or of an environmental medium for purposes of inspection and/or analysis.

produces a light pulse when struck by an alpha particle and is able to be counted.

the minimum amount of a radionuclide or other material of interest that can repeatedly be detected by an instrument, system, or procedure.

designed to provide the information needed to identify site hazards and to select worker protection methods.

a normal sample of material (gas, liquid, or solid) to which a known amount of some substance of interest is added. Spiked samples are used to check on the performance of a routine analysis or the recovery efficiency of an analytical method.

land that stands higher than its surroundings due to erosion.

used to monitor the amount $\cap$. radiation to which it has been exposed.

a particular type of confidence limit used frequently in quality control work, where the limits apply to a percentage of the individual values of the population.

an element with an atomic number greater than uranium.

areas covered or saturated with water for enough time to support water-loving vegetation. Typical wetlands include swamps, marshes, and bogs. 


\section{SER Distribution List}

\section{External Distribution}

Department of Energy, Fernald Field Office - 250 copies

This report is distributed widely by the Department of Energy to local, state, and federal agencies, Congress, the public, and the media.

Internal Distribution

Environmental Monitoring - 1,094 copies

Public Affairs - 50 copies

Library - 6 copies

Public Environmental Information Center - 100 copies 

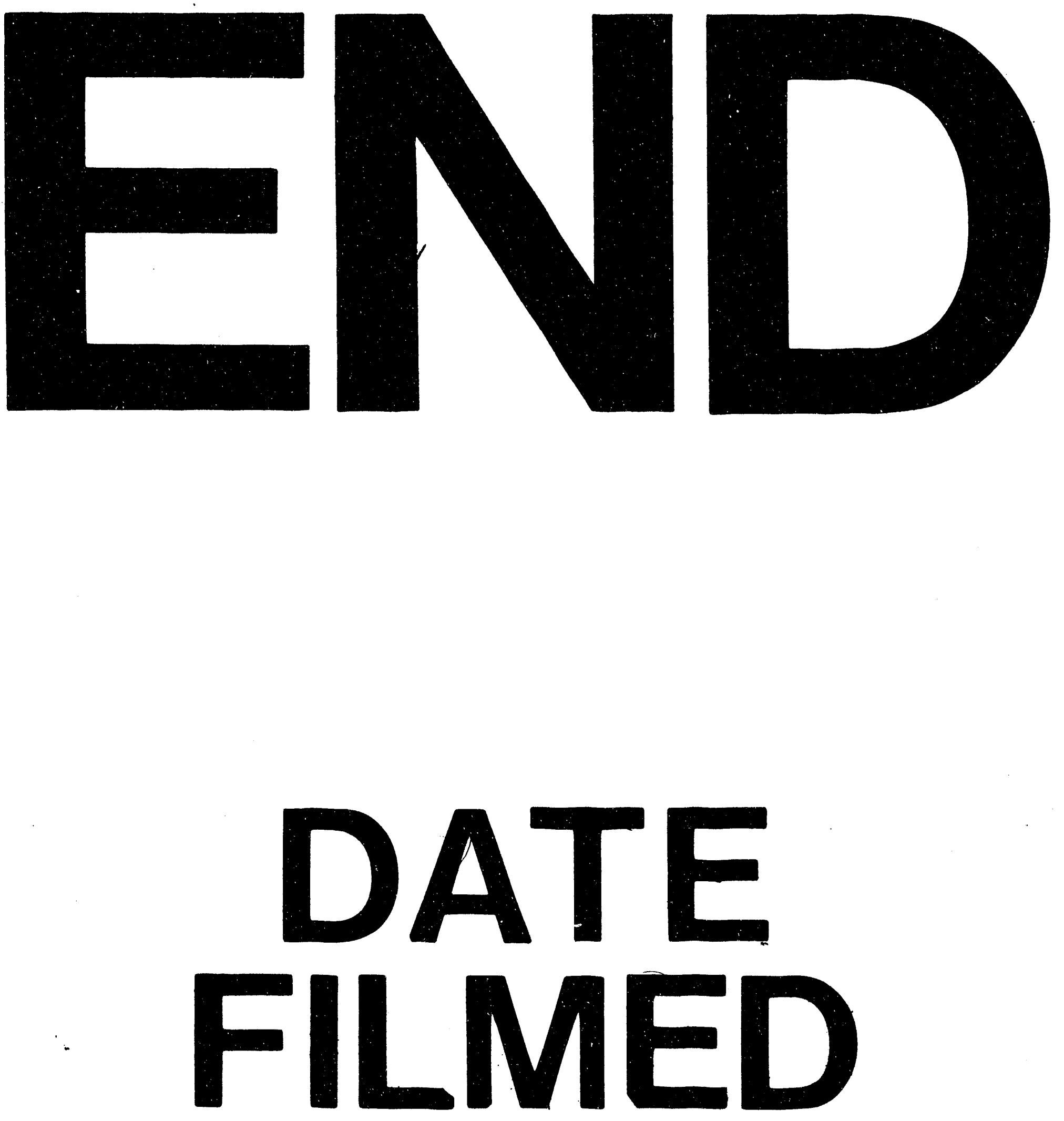

1

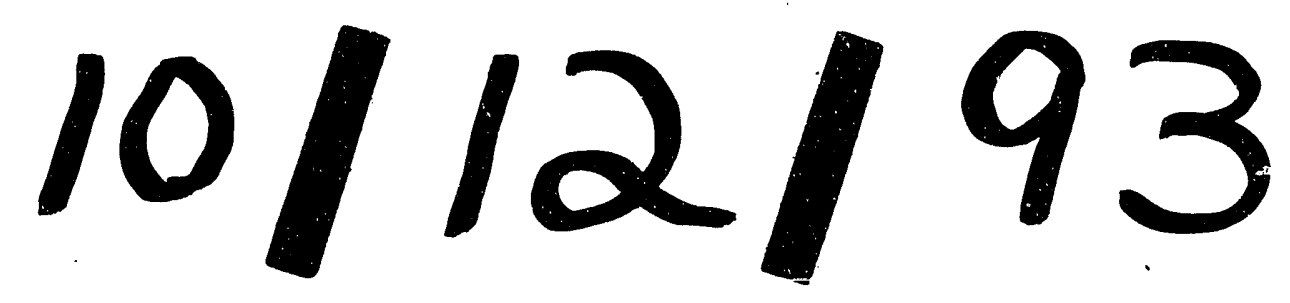


